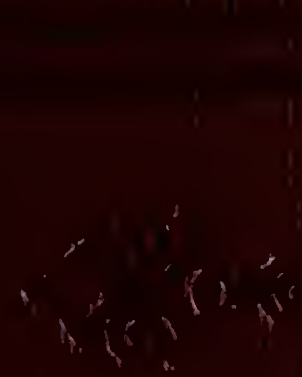



Digitized by the Internet Archive in 2013

http://archive.org/details/guidebookofweste1916camp 

DEPARTMENT OF THE INTERIOR

FRANKLIN K. LANE, Secretary

United States Geological Survey

George Otis Smith, Director

\section{Bulletin 611}

\section{GUIDEBOOK}

OF THE

\section{WESTERN UNITED STATES}

\section{PART A. THE NORTHERN PACIFIC ROUTE}

WITH A SIDE TRIP TO YELLOWSTONE PARK

BY

MARIUS R. CAMPBELL AND OTHERS

Reprinted with minor corrections

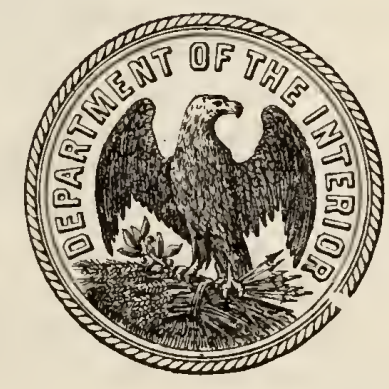

WASHINGTON

GOVERNMENT PRINTING OFFICE 
Principal Divisions of Geologic Time.a

[A glossary of geologic terms is given on pp. 199-203.]

\begin{tabular}{|c|c|c|c|c|}
\hline Era. & Period. & Epoeh. & Charaeteristie life. & $\begin{array}{l}\text { Duration, aecord- } \\
\text { ing to various } \\
\text { estimates. }\end{array}$ \\
\hline \multirow{2}{*}{$\begin{array}{l}\text { Cenozoie (re- } \\
\text { eent life). }\end{array}$} & Quaternary. & $\begin{array}{l}\text { Reeent. } \\
\text { Pleistoeene } \\
\text { (G } r \text { e a t } \\
\text { lee Age). }\end{array}$ & $\begin{array}{l}\text { "Age of man." Animals and plants of } \\
\text { modern types. }\end{array}$ & \multirow[t]{2}{*}{$\begin{array}{l}\text { Millions of years. } \\
1 \text { to } 5 .\end{array}$} \\
\hline & Tertiary. & $\begin{array}{l}\text { Plioeene. } \\
\text { Mioeene. } \\
\text { Oligoeene. } \\
\text { Eoeene. }\end{array}$ & $\begin{array}{l}\text { "Age of mammals." Possible first appear- } \\
\text { ance of man. Rise and development of } \\
\text { highest orders of plants. }\end{array}$ & \\
\hline \multirow{3}{*}{$\begin{array}{l}\text { Mesozoie (in- } \\
\text { termediate } \\
\text { life). }\end{array}$} & Cretaeeous. & $(b)$ & \multirow{3}{*}{$\begin{array}{l}\text { "Age of reptiles." Rise and eulmination } \\
\text { of huge land reptiles (dinosaurs), of shell- } \\
\text { fish with eomplexly partitioned eoiled } \\
\text { shells (ammonites), and of great flying } \\
\text { reptiles. First appearanee (in Jurassie) } \\
\text { of birds and mammals; of eyeads, an } \\
\text { order of palmlike plants (in Triassie); } \\
\text { and of angiospermous plants, among } \\
\text { whieh are palms and hardwood trees } \\
\text { (in Cretaeeous). }\end{array}$} & \multirow{3}{*}{4 to 10.} \\
\hline & Jurassie. & (b) & & \\
\hline & Triassic. & $(b)$ & & \\
\hline \multirow{7}{*}{$\begin{array}{l}\text { Paleozoie } \\
\text { (old life). }\end{array}$} & & Permian. & \multirow{3}{*}{$\begin{array}{l}\text { "Age of amphibians." Dominanee of elub } \\
\text { mosses (lyeopods) and plants of horsetail } \\
\text { and fern types. Primitive flowering } \\
\text { plants and earliest eone-bearing trees. } \\
\text { Beginnings of baekboned land animals } \\
\text { (land vertebrates). Inseets. Animals } \\
\text { with nautilus-like eoiled shells (ammon- } \\
\text { ites) and sharks abundant. }\end{array}$} & \multirow{8}{*}{$\begin{array}{l}. \\
17 \text { to } 25 .\end{array}$} \\
\hline & $\begin{array}{l}\text { Carbonifer- } \\
\text { ous. }\end{array}$ & $\begin{array}{l}\text { Pennsylva- } \\
\text { nian. }\end{array}$ & & \\
\hline & & $\begin{array}{l}\text { Missis s i p- } \\
\text { pian. }\end{array}$ & & \\
\hline & Devonian. & $(b)$ & $\begin{array}{l}\text { "Age of fishes." Shellfish (mollusks) also } \\
\text { abundant. Rise of amphibians and land } \\
\text { plants. }\end{array}$ & \\
\hline & Silurian. & (b) & $\begin{array}{l}\text { Shell-forming sea animals dominant, espe- } \\
\text { eially those related to the nautilus (eeph- } \\
\text { alopods). Rise and eulmination of the } \\
\text { marine animals sometimes known as sea } \\
\text { lilies (erinoids) and of giant seorpion- } \\
\text { like erustaeeans (eurypterids). Rise of } \\
\text { fishes and of reef-building eorals. }\end{array}$ & \\
\hline & Ordovieian. & $(b)$ & $\begin{array}{l}\text { Shell-forming sea animals, espeeially eeph- } \\
\text { alopods and mollusk-like braehiopods, } \\
\text { abundant. Culmination of the buglike } \\
\text { marine erustaeeans known as trilobites. } \\
\text { First trace of inseet life. }\end{array}$ & \\
\hline & Cambrian. & $(b)$ & $\begin{array}{l}\text { Trilobites and braehiopods most eharac- } \\
\text { teristie animals. Seaweeds (algæ) abun- } \\
\text { dant. No traee of land animals found. }\end{array}$ & \\
\hline \multirow{2}{*}{$\begin{array}{l}\text { P r o t erozoie } \\
\text { (primordial } \\
\text { life). }\end{array}$} & Algonkian. & (b) & $\begin{array}{l}\text { First life that has left distinet reeord. } \\
\text { Crustaceans, braehiopods, and seaweeds. }\end{array}$ & \\
\hline & A rehean. & $\begin{array}{l}\text { Crystalline } \\
\text { rocks. }\end{array}$ & No fossils found. & $50+$ \\
\hline
\end{tabular}

a The geologie reeord eonsists mainly of sedimentary beds-beds deposited in water. Over large areas long periods of uplift and erosion intervened between periods of deposition. Every sueh interruption in deposition in any area produees there what geologists term an uneonformity. Many of the time divisions shown above are separated by sueh uneonformities-that is, the dividing lines in the table represent loeal or widespread uplifts or depressions of the earth's surface.

$\checkmark$ Epoch names omitted; in less common use than those given. 


\section{PREFACE.}

\section{By George Otis Smith.}

The United States of America comprise an area so vast in extent and so diverse in natural features as well as in characters due to human agency that the American citizen who knows thoroughly his own country must have traveled widely and observed wisely. To "know America first" is a patriotic obligation, but to meet this obligation the railroad traveler needs to have his eyes directed toward the more important or essential things within his field of vision and then to have much that he sees explained by what is unseen in the swift passage of the train. Indeed, many things that attract his attention are inexplicable except as the story of the past is available to enable him to interpret the present. Herein lie the value and the charm of history, whether human or geologic.

The present stimulus given to travel in the home country will encourage many thousands of Americans to study geography at first hand. To make this study most profitable the traveler needs a handbook that will answer the questions that come to his mind so readily along the way. Furthermore, the aim of such a guide should be to stimulate the eye in the selection of the essentials in the scene that so rapidly unfolds itself in the crossing of the continent. In recognition of the opportunity afforded in 1915 to render service of this kind to an unusually large number of American citizens, as well as to visitors from other countries, the United States Geological Survey has prepared a series of guidebooks ${ }^{1}$ covering four of the older railroad routes west of the Mississippi.

These books are educational in purpose, but the method adopted is to entertain the traveler by making more interesting what he sees from the car window. The plan of the series is to present authoritative information that may enable the reader to realize adequately the

\footnotetext{
${ }^{1}$ Guidebook of the western United States: Part A, The Northern Pacific Route, with a side trip to Yellowstone Park (Bulletin 611); Part B, The Overland Route, with a side trip to Yellowstone Park (Bulletin 612); Part C, The Santa Fe Ronte, with a side trip to the Grand Canyon of the Colorado (Bulletin 613); Part D, The Shasta Route and Coast Line (Bulletin 614).
} 
scenic and material resources of the region he is traversing, to comprehend correctly the basis of its development, and above all to appreciate keenly the real value of the country he looks out upon, not as so many square miles of territory represented on the map in a railroad folder by meaningless spaces, but rather as land-real estate, if you please-varying widely in present appearance because differing largely in its history, and characterized by even greater variation in values because possessing diversified natural resources. One region may be such as to afford a livelihood for only a pastoral people; another may present opportunity for intensive agriculture; still another may contain hidden stores of mineral wealth that may attract large industrial development; and, taken together, these varied resources afford the promise of long-continued prosperity for this or that State.

Items of interest in civic development or references to significant epochs in the record of discovery and settlement may be interspersed with explanations of mountain and valley or statements of geologic history. In a broad way the story of the West is a unit, and every chapter should be told in order to meet fully the needs of the tourist who aims to understand all that he sees. To such a traveler-reader this series of guidebooks is addressed.

To this interpretation of our own country the United States Geological Survey brings the accumulated data of decades of pioneering investigation, and the present contribution is only one type of return to the public which has supported this scientific work under the Federal Government.

In the preparation of the description of the country traversed by the Northern Pacific Route the geographic and geologic information already published as well as unpublished material in the possession of the Geological Survey has been utilized, but to supplement this material Mr. Campbell made a field examination of the entire route in 1914. Information has been furnished by others, to whom credit is given in the text. Cooperation has been rendered by the United States Reclamation Service, railroad officials and other citizens have generally given their aid, and other members of the Survey have freely cooperated in the work. For the purpose of furnishing the traveler with a graphic presentation of each part of his route, the accompanying maps, 27 sheets in all, have been prepared, with a degree of accuracy probably never before attained in a guidebook, and their arrangement has been planned to meet the convenience of the reader. The special topographic surveys necessary to complete these maps of the route were made by J. G. Staack, C. L. Sadler, J. L. Lewis, N. E. Ballmer, and W. O. Tufts. 


\title{
Guidebook of the Western United States.
}

\section{PART A. THE NORTHERN PACIFIC ROUTE, WITH A SIDE TRIP TO YELLOWSTONE PARK.}

\author{
By Marius R. Campbeli and others.
}

\section{INTRODUCTION.}

If his journey to the Pacific coast begins at one of the great cities on the Atlantic seaboard, the traveler, when he reaches St. Paul, the eastern terminus of the Northern Pacific Railway, will have gone nearly halfway across North America. He will have traversed or perhaps gone around the Appalachian Mountain region and then crossed the prairie States, which, in wealth and population, form in themselves an empire.

St. Paul is in the prairie region, but the boundary between the prairies and the Great Plains is vague and undefined, and the traveler will at no place perceive the change from prairie to plain or from the East to the West. On leaving St. Paul he first passes across rolling prairies, interspersed with forests of pine and hardwood trees, and within a short distance these prairies give place to the vast treeless plains which, stretching a thousand miles west of the Mississippi, rise almost imperceptibly to the foothills of the Rocky Mountains. The annual rainfall diminishes in the same direction from 28 inches at St. Paul to only half that amount in central Montana, and the traveler, as he goes westward, will note more and more of the features that he has habitually associated with the West. Prairie dogs and jack rabbits are seen; one by one the flowers and shrubs of the Mississippi Valley disappear and are replaced by those of a semiarid country; trees grow only on the moist bottom lands along the streams; intensive cultivation is possible only in the valleys, though the uplands are being brought into use by dry farming and are yielding fair crops of the more hardy grains.

Throughout much of the region traversed the face of the country has been greatly modified by the vast ice sheets of the glacial period which covered the northern part of the continent and left immense deposits of loose material on the surface of hard rock in the northern 
part of the United States. The history and the phenomena of this glaciation are considered in detail at several places in this book.

The general features of the country west of the Mississippi are represented on Plate I. When, after crossing the Great Plains, the traveler reaches the foothills of the Rocky Mountains he will have attained a height of 4,000 feet above the sea, a height reached by few peaks in the Eastern States outside of the Adirondacks and the White Mountains. The Rocky Mountains form a great, irregular, roughhewn "backbone" for the continent. They comprise many groups of ranges, in which some peaks in Montana and Idaho reach a height of 12,000 feet above sea level and some in Colorado rise more than 14,000 feet.

The western mountains, like the eastern, are the worn remnants of upward folds or crumples or of upheaved blocks of the fractured earth crust, but, unlike the eastern mountains, which are geologically old, the western mountains are geologically very young. They are therefore higher, for since they were uplifted there has not been time for ice, rain, heat, frost, and wind to wear them down to lower lovels.

West of the Rocky Mountains lies a broad interior basin, in the northern part of which, with its inclosing mountains, there is sufficient rain and snow to maintain the flow of the great Columbia River; but in the southern part, in what is known as the Great Basin, the mountain streams find no outlets to the sea, their waters, so precious for irrigation, being soon lost in the thirsty lowlands, and the feeble or intermittent rivers of the valleys carry their waters down to be evaporated in alkali marshes or on saline deserts.

The part of the Columbia River basin or plateau that is traversed by the Northern Pacific Railway is made up of lava flows, among the greatest in the world, which in comparatively recent geologic time spread like a fiery flood over hundreds of thousands of square miles; and a wide expanse of hard, dark volcanic rocks, whose surface is here and there cut deeply by streams, shows the enormous extent and volume of these eruptions. The part of this old lava plain that is crossed by Columbia River is the most arid region traversed by this route. The precipitation in this region is sometimes not more than 6 inches annually, but despite the small rainfall the uplands have become the great wheat-raising country of the Northwest.

The last great natural feature to be crossed by the traveler is the Cascade Range, which separates the interior basin from the region of Puget Sound. This range is a broad upland that stands from 6,000 to 8,000 feet above the sea, and here the evidences of volcanic activity continue to be conspicuous. On the flanks of the range rise the snowcovered peaks of Mount Rainier, Mount Adams, and other cones, which were once active volcanoes, pouring forth streams of lava and 

showers of rock fragments. Of these great conical masses, built up by successive lava flows and by the accumulation of rock fragments blown from the craters, the highest is Mount Rainier, towering 14,408 feet above Puget Sound, from which it presents a magnificent spectacle, its upper slopes covered by great streams of moving ice, the largest glaciers in the United States south of Alaska.

On emerging from the Cascades the traveler enters a broad lowland, which is separated from the Pacific Ocean by the Olympic Mountains, but which contains Puget Sound with its many branching waterways, one of the most remarkable bodies of salt water on the globe.

Note.-For the convenience of the traveler the sheets of the route map in this bulletin are so arranged that he can unfold them one by one and keep each one in view while he is reading the text relating to it. A reference is made in the text to each sheet at the place where it should be so unfolded, and the areas covered by the sheets are shown on Plate I. A list, of these sheets and of other illustrations, showing where each one is placed in the book, is given on pages 205-207. A glossary of geologic terms is given on pages 199-203 and an index of stations on pages 209-212. 


\section{ITINERARY.}

The traveler who is interested in the geologic history of this country - a history that reaches back into the dim and misty past, to a time long before Father Hennepin first saw the Falls of St. Anthony and the Mississippi Valley in 1680-will find much to attract his attention about St. Paul and Minneapolis. If he has only a few hours at his disposal he can easily obtain a general view of the valley of the Mississippi and the rocks composing its bluffs from the Robert or Wabasha Street Bridge in St. Paul, both of which are within a few minutes' walk of the Union Station. If he chooses the Wabasha Street Bridge, which in some respects affords a better view, he will see that the Mississippi is flowing in a broad valley from 100 to 200 feet deep. In some places the walls of the valley are composed of solid rock, but in others they are made up of loose material, such as clay, sand, or gravel, which forms either large masses or is spread as a thin coating over the rocky slopes. As the valley has been cut in the hard rock by the river, it is a record of stream carving and of the climatic and geographic conditions under which the carving was done. Not only are the recent events of geologic history recorded in the size and shape of the valley, but the much earlier events in the history of the globe have left a record in the solid rock itself-a record that, when correctly read, tells of the presence of a sea in which limy muds were accumulating or along the shore of which sand was washed back and forth by the waves or drifted into heaps by the wind. Every one is more or less familiar with the history of Minnesota during the last 250 years, or since the white man first visited the region, but few know anything of the far more ancient history recorded in the rocks and in the hills and valleys of the region. It is to this ancient history, dealing with the time before man is supposed to have existed upon the globe, that the reader's attention is now invited.

The bluff upon which the Wabasha Street Bridge rests is composed almost entirely of white sandstone (St. Peter ${ }^{1}$ ), which is very, very old, but despite its great age is so soft that it can be crushed in the hand. Streams of water flowing through the rock have carved great underground channels in it, and more recently boys have dug caves in the soft sand along the river front directly below the bridge.

1 The rocks exposed at the surface in the vicinity of St. Paul and those revealed by deep drilling are shown in the table on page 9 . The natural order of the formations named in the table, from top to bottom, is shown by the order in which the 
Jonathan Carver, in describing his journey to this region in 1766, mentions a large cave in the St. Peter sandstone about 30 miles below the Falls of St. Anthony, a cave called by the Indians the "Dwelling of the Great Spirit." In this cave they held religious ceremonies, and near it they buried their dead. When the sandstone is examined under a magnifying glass it is found to be composed of beautifully white translucent grains of quartz, resembling rock candy except that the fragments are round instead of angular. The even lines of bedding, which can be seen from either of the bridges mentioned, show that the sand must have been laid down in water, but the forms of the individual grains show with equal certainty that the sand before it was washed into the ocean and deposited along the shore was blown about by the wind and perhaps heaped into large dunes, such as are now seen around the head of Lake Michigan south of Chicago.

The St. Peter sandstone, on account of its purity, is well adapted to glass making and in many places it is used for that purpose. It extends from St. Paul southward as far as central Arkansas and eastward as far as Detroit, and probably once extended much farther north, but in that direction it has been eroded-worn away by frost, rains, and streams-until all trace of it is lost. On account of its wide distribution and the purity of the materials that compose it, this deposit of sand is one of the most remarkable in the world.

Above this sandstone, if stone it may be called, lies a thin-bedded limestone known as the Platteville, which can be seen at the entrance to the Wabasha Street Bridge and which was formerly used about the "twin cities" for building material. The stone occurs, however, in thin layers and does not stand the weather well, so that very

names are printed. The place of each of the larger units of rock or of time (as Cambrian, Ordovician) in the general geologic column is shown in the table on page 2.

Ordovician:

Thickness

in feet.

Galena limestone (exposed)................... 15

Decorah shale (exposed)..................... 60

Platteville limestone (exposed). . . . . . . . . . . 30

St. Peter sandstone (exposed).................. 150

Shakopee dolomite........................ 60

Oneota dolomite......................... 100

Cambrian:

Jordan sandstone............................. 75

St. Lawrence formation..................... 100

Franconia sandstone, Dresbach sandstone, and under-

lying rocks....................... 500

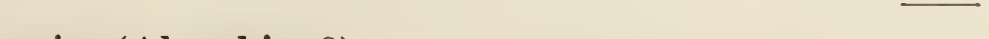

Red clastic series (Algonkian?).................... 1, 125

Granite. 
little of it is now used. This limestone contains here and there fossil sea shells, which show clearly that the sandy shore of the St. Peter epoch finally sank and was covered by the sea. The shells of the animals that inhabited this sea sank to the bottom when the animals died and were buried in the limy mud that later became hardened into limestone, which preserved not only the shells but all the beautiful ornamentation on their surfaces.

If the traveler can spend a day or two here instead of a few hours, he may take many pleasant rides by trolley or automobile into the surrounding country to places of historic and scenic interest. Whether his visit is one of business or one of pleasure, he should not fail to see old Fort Snelling and the Falls of Minnehaha. Fort Snelling stands on the green, tree-shaded bluffs that overlook the peaceful valley of the Mississippi, and it is hard to realize that when it was established, only a few years after Zebulon M. Pike made his journey to the source of the Mississippi, ${ }^{1}$ it was in the heart of the Indian country. It is doubtful if at that time anyone dreamed that near its site would rise such cities as St. Paul and Minneapolis. In the early days Fort Snelling was the starting point of several military expeditions that were sent out to explore the great Northwest.

'The Falls of Minnehaha, which are about $2 \frac{1}{2}$ miles farther north, offer none of the sinister suggestions of war that still linger round the fort; on the contrary, they have an atmosphere of love and romance, and the journey of Hiawatha and Minnehaha, as related by Longfellow, is fittingly commemorated by a bronze group at the head of the falls. (See Pl. II.)

${ }^{1}$ Soon after the acquisition from France of Louisiana, which included most of the territory west of Mississippi River, Lieut. Z. M. Pike was commissioned by President Jefferson to explore the new territory and to find the source of the river. When Pike reached the mouth of St. Peter (now Minnesota) River, in 1805, he recognized the strategic importance of the point for military purposes and procured from the Indians title for the Government to the land from the mouth of St. Peter River to and including the Falls of St. Anthony. In his report on the explorations he recommended that a fort be established on the bluff between St. Peter and Mississippi rivers. Nothing came of his recommendation until February 10, 1819, when John C. Calhoun, Secretary of War, ordered the Fifth Infantry, under Col. Henry Leavenworth, to establish headquarters at this place. Col. Leavenworth reached the mouth of St. Peter River on September 24 of the same year, but instead of occupying the bluff recommended by Pike he camped across the river, where the village of Mendota now stands. In 1820 Col. Leavenworth was relieved by Col. Josiah Snelling, who determined to build a permanent post on the spot originally selected by Pike. The corner stone is supposed to have been laid on September 10, 1820 , and the post was occupied by the troops in 1822. The fort was originally called St. Anthony, but the name was changed to Snelling at the recommendation of Gen. Winfield Scott, who visited it while on a tour of inspection in 1824 . Fort Snelling has been continuously occupied as a military post from 1822 to the present time. 




MINNEHAHA, "LAUGHING WATER."

Height of fall, 54 feet. Water fumbles over St. Peter sandstone, which is gradually being cut back toward Lake Minnetonka. Photograph by Haynes, St. Paul, Mınn. 


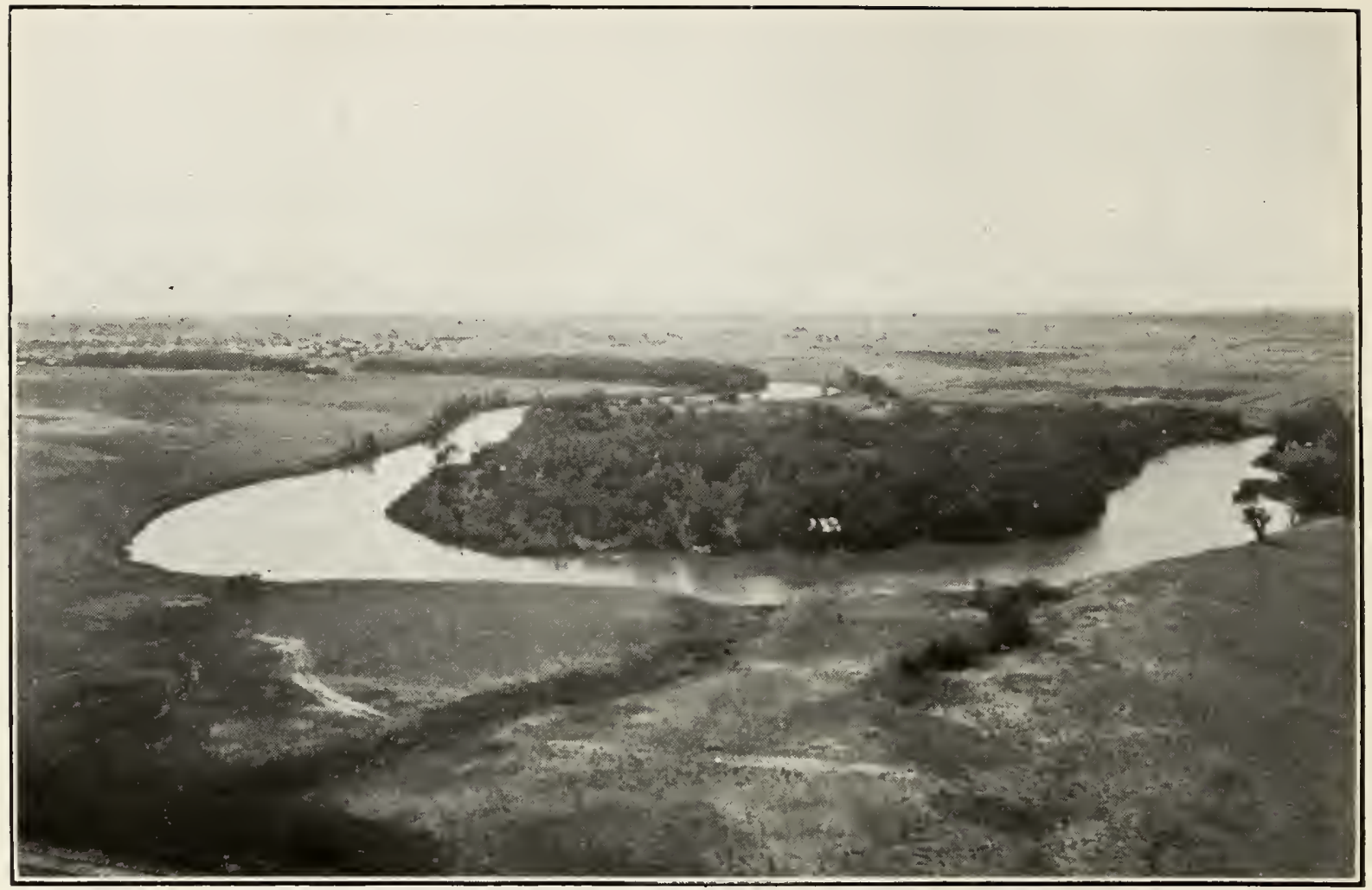

A. VALLEY CITY, N. DAK., FROM THE "HIGH LINE."

The river meanders broadly on the glacial drift which partly fills the old rock-cut valley. Photograph by Johnson \& Olson, Alexandria, Minn.

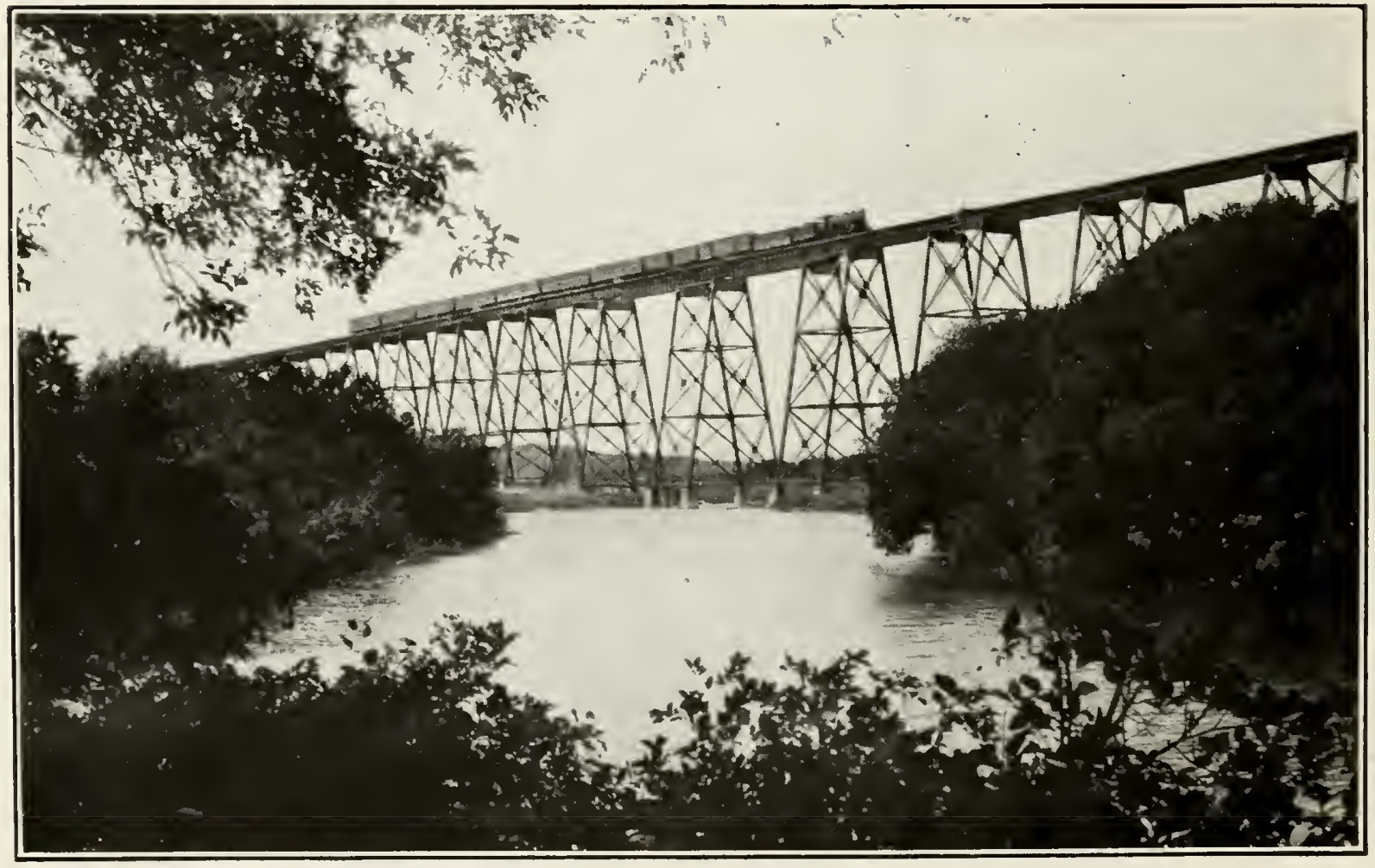

B. THE "HIGH LINE" ACROSS THE VALLEY OF SHEYENNE RIVER, N. DAK.

Height of trestle (150 feet) indicates depth of valley. Photograph by Johnson \& Olson, Alexandria, Minn. 
Fort Snelling and the Falls of Minnehaha can be reached from St. Paul by several routes, but whoever wishes to see the rocks and the way they have been carved by the streams should take the Snelling car, which follows the Mississippi upstream for about 6 miles directly to Fort Snelling. The roadway is on a bench or terrace nearly half a mile wide, which stands about 100 feet above the river and on a part of which the business portion of St. Paul has been built. The terrace is underlain by the Platteville limestone, which may be seen at a number of places, and it is evidently a remnant of a valley that existed there before the present channel of the river was excavated in its floor. The accompanying diagram (fig. 1) is a cross section of the valley as it appears to-day. If the channel of the river should be filled to the broken line it would represent the valley floor as it was before the present channel was cut, when the river was flowing at the level of the terrace. As the rocks are not exposed at any place in the bottom of the valley it is evident that the old rock-cut valley has been filled by sediment (alluvium) brought down by the stream, but the depth of this filling has not been accurately deter-

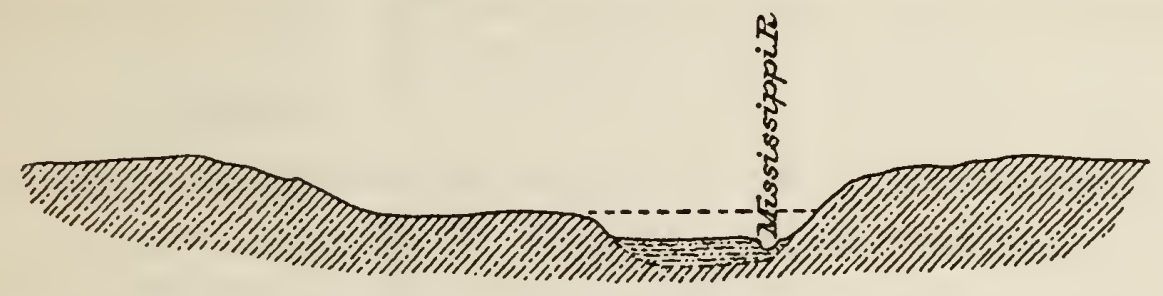

Figure 1.-Section across Mississippi Valley between St. Paul and Fort Snelling, Minn., looking east. The broken line represents the bottom of the valley before the present channel was cut.

mined. A deep well sunk in St. Paul northeast of the Union Station struck solid rock 100 feet below river level. At some remote time the river channel was therefore at least 100 feet deeper than it is now, and since that time it has been filled by mud and sand up to the level of the present river bottom.

At Fort Snelling the main valley continues to the southwest, but it is occupied only by Minnesota River, ${ }^{1}$ a stream manifestly too small for the valley in which it is flowing; and, on the other hand, Mississippi River above Fort Snelling is out of proportion to the narrow gorge in which it is confined. To even the most casual observer the streams appear to be misplaced; the larger stream is flowing in the smaller valley and vice versa. The size and relation of the river valleys about St. Paul show clearly that they have undergone many changes which do not occur in streams developing under normal conditions. Changes of this kind have taken place in many of the streams in the northern part of the United States. They are

1 Featherstonhaugh says that the In- $\mid$ white settlers the name St. Peter was dian name of this river was Minnay Sotor, applied to it; but later the Indian name meaning turbid waters. By the early was revived, with the spelling Minnesota. 
due to the invasion of this country at various epochs in the past by great glaciers which filled existing valleys with the mud, sand, and gravel that they brought in from the north. (See footnote on pp. 26-30.) When the ice vanished the streams found different courses, developing lakes and falls, features characteristic of a newly established drainage system.

Thus the original drainage about St. Paul consisted of a stream flowing southeastward through the city and following the present course of Mississippi River to a point 10 or 12 miles below St. Paul, where it was joined by a large stream from the west, which crossed the present river valley 4 or 5 miles above Fort Snelling. At that time there was no stream flowing from Fort Snelling to St. Paul. This area was then a rocky upland.

When the western ice sheet (see route map, sheet 1, p. 20) melted back from this region, all these old stream channels were filled with glacial materials, and the principal streams were developed along their present courses. After a time the glacier, which came from the north or northwest, melted back into the Red River valley, and Lake Agassiz (ag'a-see) came into existence. (See footnote on p. 32.) Warren River, the outlet of this large body of water, occupied the present valley of Minnesota River and received Mississippi River as a tributary from the north. This great river flowed across the rocky upland between Fort Snelling and St. Paul and cut a broad valley, upon the floor of which St. Paul has been built. Where it joined the old valley, at the site of St. Paul, there was a waterfall many times the size of St. Anthony. This fall gradually receded upstream until it reached the other old valley above Fort Snelling, and thus the inner rock gorge shown in the diagram was cut.

The gorge of the Mississippi from Fort Snelling to the Falls of St. Anthony, which are a short distance below the station in Minneapolis, shows from its extreme narrowness that it is new and that it has only recently been carved out of the solid rock by the swiftly flowing stream. ${ }^{1}$ In fact, the process of carving the gorge of the Mississippi is still in operation, or was before it was arrested by the hand of man.

\footnotetext{
${ }^{1}$ Many take it for granted that the surface features of the earth have always been the same as they are to-day, that the valleys have always been valleys and the hills and mountains always eminences overlooking them. The incorrectness of such an assumption, however, can be realized by watching any small stream or rill after or during a rain. It will be seen that the stream is busily engaged in cutting the sand or clay over which it flows
}

and carrying it down the valley to be dropped where the current slackens in some pond or lake. Every fragment, as it is loosened from the bed of the stream, is carried or rolled along by the water a few inches or a few feet and then dropped, because the stream is unable to move it farther, as a tired man lays down his burden a moment to rest. By dropping many grains the power of the water is restored and the grain of sand is again picked up, 
Rivers always deepen their channels toward the head of the stream, and the Falls of St. Anthony have doubtless receded slowly from a point near the edge of the main valley at Fort Snelling to their present position. As the rate of recession of this fall has apparently been fairly uniform, and as the distance which the fall has retreated is well known, it has been used in making estimates of the time that has elapsed since the river first started to cut its gorge near Fort Snelling. According to the best estimate, the fall has been 12,000 years in traveling from the vicinity of Fort Snelling to its present position, and it has been 8,000 years since glacial Warren River ceased to flow and the present river system came into existence.

When the receding Falls of St. Anthony reached and passed the mouth of Minnehaha Creek that stream plunged into the deepened gorge and the Falls of Minnehaha originated. Since that time they have been worn back about 400 feet to their present position. Each day some particle of rock is dislodged or worn away, and gradually the falls are working back up the stream. In the course of time they will reach Lake Minnetonka, and then this beautiful sheet of water will be drained, but that catastrophe will occur so far in the future that the owners of the hotels and summer cottages that line its shore need not be alarmed.

Lake Minnetonka is also the direct result of the occupation of the country by the ice, as are the 10,000 other lakes which Minnesota is reported to contain. Their mode of origin, which is extremely interesting, will be discussed in connection with a description of the many other lakes that will come into the traveler's view as he continues his westward journey. Lake Minnetonka is easily reached by trolley from both St. Paul and Minneapolis, and an afternoon or evening spent along its beautiful shores makes a most acceptable break in a long transcontinental journey. White Bear Lake, about 6 miles north of St. Paul, bears the same relation to that city as a summer resort that Lake Minnetonka bears to Minneapolis.

The site of the present city of St. Paul is said to have been a favorite gathering ground for the Sioux Indians long before white men invaded

as the man recovers strength and resumes his burden, and is carried or rolled along for a short distance farther. This operation is repeated many, many times, until the grain of sand is finally transported to the sea and finds a resting place upon its sandy shore.

The method by which a stream cuts hard rocks is not so obvious as that by which it cuts sand and clay. The cutting is not done by the water itself, for water alone has no cutting power. The grains of sand and the pebbles that are swept along by the current act as a great rasp, scouring and cutting the hard rocks over which they are carried. Thus grain by grain the rocks are worn away and grain by grain the material is carried to the sea. The process, though slow, never stops; and in time it carves such gorges as that of the Mississippi and even the deeper canyons found in the western mountains. 
their hunting grounds, and it is probable that for many generations Indian villages stood within what are now the city limits. When the white men came they located at Mendota, on the south side of Mississippi River near the mouth of the Minnesota, and this was the first settlement in the State. What is now the city of St. Paul was settled more recently, and its origin and the manner in which it received its name are interesting events in the history of this region. ${ }^{1}$

The State of Minnesota has a gross area of 84,682 square miles, of which 3,824 square miles is covered with water. It was admitted to the Union in 1858, and its population according to Minnesota. the census of 1910 was $2,075,708$. The earliest settlements were made along Mississippi River, which was then the main artery of commerce in this part of the country. From this valley the incoming people spread to other valleys and to the general upland between the principal streams. This was essentially an agricultural population, and it has covered all the southern and western parts of the State. The northeastern part was originally a land of swamps and heavy timber, not at all inviting to the man in search of a farm, and for this reason all of that part except a small area about the head of Lake Superior remained for a long time comparatively unknown.

While the agricultural lands of southern Minnesota were being converted into prosperous farms, the natural water power at the Falls of St. Anthony attracted the attention of millers, and great flour mills sprang up to grind the wheat that came pouring in from the surrounding region. At the same time the pine forest began to be utilized, and soon the great mills were denuding the country of its valuable timber.

The last great industry to develop was the mining of iron ore in the northern part of the State. Though the output of the mines is of less value than the products of either agriculture or manufacturing, it has probably brought the State into public notice to a greater degree than either of the others, for Minnesota is now the greatest producer of iron ore in the country, having in 1913 an output of nearly $39,000,000$ long tons, out of a total for the entire country of $62,000,000$ tons. The first iron mines in the State were opened in the Vermilion

\footnotetext{
${ }^{1}$ When the military post of Fort Snelling was established, in 1820 , the boundaries of the reservation had not been determined and consequently the post was overrun with all sorts of camp followers. In 1839 the limits of the reservation were fixed and efforts were made to eliminate the undesirable element, but not until May 6,1840 , were the troops successful in

evicting all the roughs and in demolishing their cabins. The evicted persons crossed the river and started a hamlet near the spot where the Union Station at St. Paul now stands. This was soon graced by a Roman Catholic chapel called St. Paul's, which gave its name to the village. From such inauspicious beginnings the city has developed.
} 
range ${ }^{1}$ in 1884 . The great Mesabi range was opened in 1892 and the Cuyuna range in 1911.

The values of the products of the State are approximately as follows: Manufactures (1909), \$409,000,000; agriculture (1909), \$275,000,000; mining (1913), $\$ 70,000,000$.

The locations of the centers of commerce and industry in this State, as in many others that were settled in the early days, were determined largely by the availability of water transportation. Thus St. Paul, which stands at the head of navigation on Mississippi River, and Duluth, which is at the upper end of Lake Superior, were the principal points. The use of Mississippi River as a commercial highway has gradually diminished, until to-day it has little or no effect on the commerce of the Northwest; but St. Paul and Minneapolis still continue to form a center for all the northern transcontinental railroads and also for those that connect central Canada with the United States. Lake Superior still holds its own as a water route for heavy freightiron ore and grain going east and coal and manufactured articles going west-and the places at which most of this traffic concentrates are Duluth and Superior, at the extreme western point of the lake.

On leaving the Union Station at ${ }^{\circ}$ St. Paul (see sheet 1, p. 20) the Northern Pacific Railway follows a small ravine almost due north for

\section{St. Paul.}

Elevation 732 feet. Population 214,744.2 about 2 miles, gradually climbing from an altitude of 732 feet at the station to more than 900 feet at the highest point within the city limits. In passing over this part of the road the traveler unacquainted with glacial topography will have an opportunity to become familiar with some of its peculiarities-its knobs and basins composed of materials which the moving ice carried or pushed along and deposited near its margin.

The region was at one time covered (as shown on the map of Minnesota on sheet 3, p. 32) by what is here called the middle ice sheet, which, as it came down from the north, brought into this region clay and fragments of red rock from the country north of Lake Superior. This body of ice extended southward beyond St. Paul and on melting left its load of reddish clay, sand, gravel, and bowlders, commonly known as drift, spread over the surface like a blanket. Later another

1 The term range, as applied to a deposit of iron ore or to the ore and the rocks with which the ore is associated, is limited to the Lake Superior region. It doubtless resulted from the fact that in the first districts developed the rocks associated with the ore are hard and form ridges or low ranges. From these districts the term has been carried to the other deposits of iron ore in the region, until now they are all known as ranges, even if the surface is flat and swampy.

2 The figures for population in this book are those of the United States Census of 1910. For unincorporated places the figures give the population of the election precinct, township, or like unit; such figures are marked with an asterisk (*). 
large glacier, the western ice sheet, invaded Minnesota from the northwest and spread a mantle of gray drift over part of the area already covered by red drift. The boundary between these two drift sheets passes through St. Paul but is not a sharp line of separation.

When the front of the western ice sheet rested on the hills about St. Paul streams of water issued from the ice and carried with them vast quantities of sand and gravel, which they deposited beyond the ice front. One of these streams left the ice mass in the vicinity of Minneapolis and spread a great sheet of sand and gravel over the country upon which St. Paul has been built. It is mainly these outwash materials that can be seen from the Northern Pacific trains as they pass from St. Paul to Minneapolis. The gravel was deposited irregularly and now forms knobs that are separated by kettle-like depressions. Lake Como, on the right (north) ${ }^{1}$ of the railway, lies in a basin of this character.

Descending somewhat from the high land the railway crosses the gorge or canyon cut by Mississippi River in the Platteville limestone and St. Peter sandstone. These rocks were formerly well exposed here, but they have been obscured by the construction of mills and the slumping in of soil from the top of the bluffs. While crossing the river the traveler can see on the right what remains of the Falls of St. Anthony, after a large part of the water has been diverted for the development of power. Further erosion of the rock has been prevented by the building of a low dam at the crest of the fall, and about 35,000 horsepower has been generated for running the great flour mills that line the river bank for some distance.

On the left are the buildings of the University of Minnesota, which occupy a commanding position on the east side of the river. The rocks rise toward the north, as shown by fig-

\section{Minneapolis.}

Elevation 854 feet. Population 301,408. St. Paul 10 miles. ${ }^{2}$ ure 2 (p. 17), even more steeply than the grade of the stream, and the top of the St. Peter sandstone and the overlying Platteville limestone appear higher in the canyon wall than they do at Fort Snelling. Immediately after crossing the river the train enters the Union Station at Minneapolis, to receive other travelers bound for the far West.

North of Minneapolis the railway again crosses Mississippi River, but here there is no gorge, the river flowing in a shallow valley in the drift-covered plain. Just beyond Northtown, on the right (east), the St. Peter sandstone is visible for the last time. This outcrop lies at considerably higher level than any outcrop of the sandstone in the gorge below the Falls of St. Anthony, indicating that the beds of rock rise northward more steeply than the surface of the

1 The terms right and left refer to the westbound journey.

2 The figures giving distance from St. Paul are taken from the Northern Pacific Railway folder of 1915. 
ground. As this northward rise continues up the Mississippi until the underlying granite is brought to the surface about St. Cloud it is probable that in the past the St. Peter sandstone and associated beds extended farther northward than at present. They were, however, worn away by the weather, the streams, and the ice, until now the railway passes over their beveled edges onto lower and lower formations toward the north, as shown by figure 2 .

The Great Northern and Northern Pacific railways operate the line from Minneapolis to St. Cloud jointly. At Coon Creek a branch of the Great Northern turns nearly due north and

\section{Coon Creek.}

Elevation 893 feet. St. Paul 23 miles. joins a line of the same system from St. Cloud to Duluth. In this part of the valley the surface is composed largely of sand and gravel washed out from the glacier when its front lay a short distance to the northwest. The fine part of this material when dried was picked up by the west winds and carried over the country to the east, forming sand dunes which, with intervening marshes, still characterize this part of the country, as shown on the map.

The succession of events during the several invasions of this country by the ice and the various

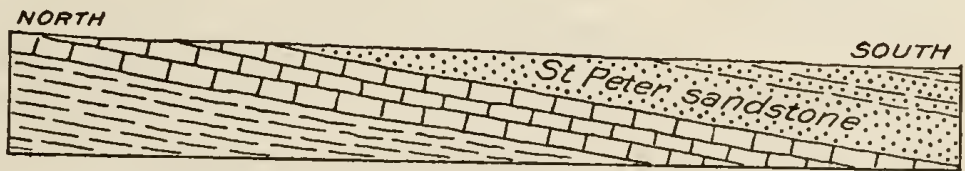

FIGURE 2.-Diagram showing northward rise of the rocks in the vicinity of Minneapolis, Minn.

materials deposited by the ice sheets are described in the footnotes on pages $26-30$.

For nearly 100 miles the railway follows the valley of the Mississippi, here a broad and flat depression much of which has the appearance of a level plain; but in places the low hills on Anoka. both sides approach the river and the valley is conElevation 904 feet. fined by fairly definite bounding walls. About Population 3,972 . Anoka the floor of the valley consists of a gently
St. Paul 29 miles. St. Paul 29 miles. undulating plain. The river has cut its channel but little below the general surface, and it seems to wander over the plain without plan or purpose, except to discharge its waters southward. The valley is well cultivated, and the glacial hills and wooded banks of the river are just sufficient to break the monotony of its even surface.

Although no rocks are exposed about Anoka, deep drilling for water has shown that the glacial drift there is about 80 feet thick and that the underlying rock is probably a part of the Dresbach sandstone. (See footnote on p. 9.) About Anoka flowing wells obtain water from this sandstone, and in the southeastern part of Anoka County millions of gallons are pumped from it daily to St. Paul for the city supply.

40063-Bull. 611-16-2 
The route followed from Minneapolis through Dayton and beyond is rich in historic association. The first white man to traverse it was Father Louis Hennepin, who in 1680 named the

Dayton.

Elevation 911 feet. Population 343. St. Paul 35 miles.

Falls of St. Anthony and St. Francis River. There is some doubt about the stream to which Hennepin applied the name St. Francis. Some think it was the stream now bearing that name; others think it was Rum River, which joins the Mississippi at Anoka. Hennepin traversed part of the Indian trail to Lake Superior, which is generally supposed to have passed by a portage from St. Francis River to Mille Lacs, thereby saving greatly in distance over the route up Rum River.

At the village of Elk River the stream visible from the train is Elk River, and this is in sight for several miles west of the station.

St. Francis River enters Elk River nearly due north

Elk River.

Elevation 924 feet. Population 859.

St. Paul 41 miles. of Big Lake station, but can not be seen from the railway. At the town of Elk River a branch of the Great Northern turns to the right (north) and joins the St. Cloud-Duluth line at the town of Milaca.

The second white man to traverse this part of the valley was Jonathan Carver, who visited the region in 1766 in order to claim it for the British sovereign. Carver ascended the Mississippi as far as St. Francis River in an endeavor to reach the Pacific coast, but owing to lack of supplies he was obliged to abandon the expedition and return to the East. Of the American pioneers, Lieut. Zebulon M. Pike, for whom Pikes Peak was subsequently named, was the first to visit the newly acquired territory in his search for the source of Mississippi River in 1805. An account of his journey will be found in the footnote on page 20 .

Later the route up the Mississippi from Fort Snelling to Sauk Rapids became widely known as a part of the Red River trail. Over this trail several exploring expeditions went into the Big Lake.

Elevation $\$ 60$ feet. Population 229. St. Paul 49 miles. Northwest, but probably the most important, at least so far as its influence on the location and building of the Northern Pacific Railroad was concerned, was the party of Government engineers under the leadership of Gov. I. I. Stevens, which made the first surveys for a Pacific railroad in 1853. 'This expedition followed the Red River trail by the sites of Big Lake, Becker, and Clear Lake to Sauk Rapids, and thence westward to Bois des Sioux River, which it crossed

Becker.

Elevation 996 feet. Population 210. St. Paul 57 miles. just below the outlet of Traverse Lake. Although the country traversed by this expedition in Minnesota and a part of North Dakota was well known, even at that early date, its route farther west lay in large part over virgin territory, and the results of its explorations have been of 
great value in the subsequent development of the region. 'The engineers of this expedition explored most of the prominent passes through the Rocky Mountains in Montana and the Cascade Mountains in Washington, and practically outlined the route that was followed by the Northern Pacific engineers some 20 years later.

In the vicinity of the village of Clear Lake the railway passes from the gray drift that was brought into this region by the western ice sheet from the Red River valley to the red drift of Clear Lake.

Elevation 1,016 feet. Population 263. St. Paul 64 miles.

the middle ice sheet. The exact point of change from one of these drift sheets to the other can not be determined from the train, but close observation will show that there are more fragments of red rock in the drift north of Clear Lake than there are in the drift south of that place. Although the glacial drift covers this country so completely that the hard rocks are hidden from view, deep drilling for water has shown that all the sedimentary rocks ${ }^{1}$ underlying the drift in the country farther south have been eroded from this region and that nothing is left but the granitic rocks which are supposed to form tho basement or foundation of this part of the continent. Fortunately these rocks are exposed at several places along the line, so that the traveler may see them and realize how different they are from the stratified sandstone and limestone that show at the surface in the vicinity of St. Paul and Minneapolis.

After passing milepost 71, beyond Cable, the train runs close to the State reformatory, which stands to the left of the railway. The walls and buildings of this institution are constructed of blue-gray granite quarried on the premises. The granite is an excellent building stone, being durable and of pleasing appearance, and beyond the reformatory it is quarried commercially. The stone can be obtained in fairly large blocks, and it has been used extensively in St. Paul and Minneapolis and shipped to different parts of the country. ${ }^{2}$ A large

${ }^{1}$ Sedimentary rocks are those that were laid down as sediments, either in lakes or in the sea. They were deposited layer upon layer, and these layers show to-day in what is known as the bedding or stratification of the rocks. Where the material deposited was very fine and was supplied in small - amounts and intermittently the layers are very thin, in some places as thin as paper; but where the material deposited was coarse and was supplied in great abundance, or where it was of such character that it did not form distinct layers, the beds may be very thick or even massivethat is, they may show no bedding planes.

2 The quarrying of granite for buildings and monuments is an old and well- established industry in this part of the State. The first quarry was opened at East St. Cloud in 1868. Since that time numerous quarries have been developed at East St. Cloud, Sauk Rapids, and Watab, on the east side of the river, and at St. Cloud and Rockville, on the west side. The quarries in this vicinity produce both red and gray granites of varying degrees of coarseness, ranging from fine gray granite suitable for monuments to coarse red and gray granites that can be used only as huilding stone. In 1913 the granite quarried in Stearns, Benton, and Sherburne counties, with St. Cloud as a center, was valued at about $\$ 850,000$. 
amount of it was used in the new State capitol. The granite is hard and resistant, forming the rapids in the river and the rough topography that marks the valley for some distance.

The town of St. Cloud (see sheet 2, p. 26) lies on the opposite side of the river from the railway, so that the traveler can see only the

St. Cloud.

station and a few houses. A rapid in the river near

Elevation 1,050 feet.

Population 10,600.

St. Paul 76 miles.

this place is utilized to produce power for a large

milling industry. Here the main line of the Great Northern Railway crosses the river, but a branch of that road leading from St. Cloud to Duluth is crossed by the Northern Pacific train a short distance beyond the station.

At Sauk Rapids the low granite and drift hills that border the valley on the right (east) approach so close to the river that there is room only for a few streets and the railway between Sauk Rapids.

Elevation 1,034 feet. Population 1, 745 . St. Paul 77 miles. the hills and the river. Masses of granite can be seen in the river channel and the resistance of this rock has produced the rapids at this place. Rock of the same kind is quarried in the bluffs some distance back from the river and is brought to the main line over a short spur for shipment. Above the rapids the river flows quietly between low wooded banks, or rather in a slight depression in the bottom of the broad valley.

Although the hills are less precipitous beyond Sauk Rapids, the presence of granite in the vicinity of Watab station is attested by great bowlders of this material that were evidently picked up by the glacier and distributed along the valley, and also by old quarries that are faintly discernible on the left (west).

The traveler is now approaching the place where Pike's party wintered in 1805-6 on their memorable trip to the source of the Mississippi. ${ }^{1}$

${ }^{1}$ As soon as Louisiana had been acquired from France by the treaty signed at Paris on April 30, 1803, President Jefferson took steps to have the newly acquired country thoroughly explored. He personally planned the expedition to the Pacific coast which was'conducted by Lewis and Clark (see p. 47) in 18041806 and other expeditions by Lieut. Zebulon M. Pike to the headwaters of the Mississippi and to the great Southwest. Pike's search for the source of the Mississippi took him over ground with which the traveler is now somewhat familiar, and an account of the trip may be of interest.
The country through which Pike traveled was at that time fairly well known, but the earlier explorations had been made by French and English adventurers who were using every means to further the interests of their respective Governments. It had now become the property of the United States, and Jefferson wanted first-hand information not only regarding the geography of the country but also regarding the attitude taken toward the new owner by the Indian tribes and the trappers and traders who gathered furs from this vast wilderness.

Pike left St. Louis on August 9, 1805, with 1 sergeant, 2 corporals, and 17 pri- 


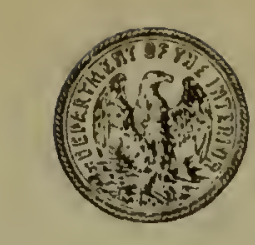

GEOLOGIC AND TOPOGRAPHIC MAP OF THE

NORTHERN PACIFIC ROUTE

From St. Paul, Minnesota, to Seattle, Washington

Base compiled from United States Geological Survey Atlas

Sheets, from railroad alignments and profiles supplied by

information collected with the assistance of this company

UNITED STATES GEOLOGICAL SURVEY

GEORGE OTIS SMITH, DIRECTOR

$\begin{array}{ll}\text { David White, Chief Geologist } & \text { R. B. Marshall, Chief Geographer }\end{array}$ 1915

Each quadrangle shown on the map with a name in parenthesis in the
lower left corner is mapped in detail on the U. S. C. S. Topographic
Sher

BULLETIN 611

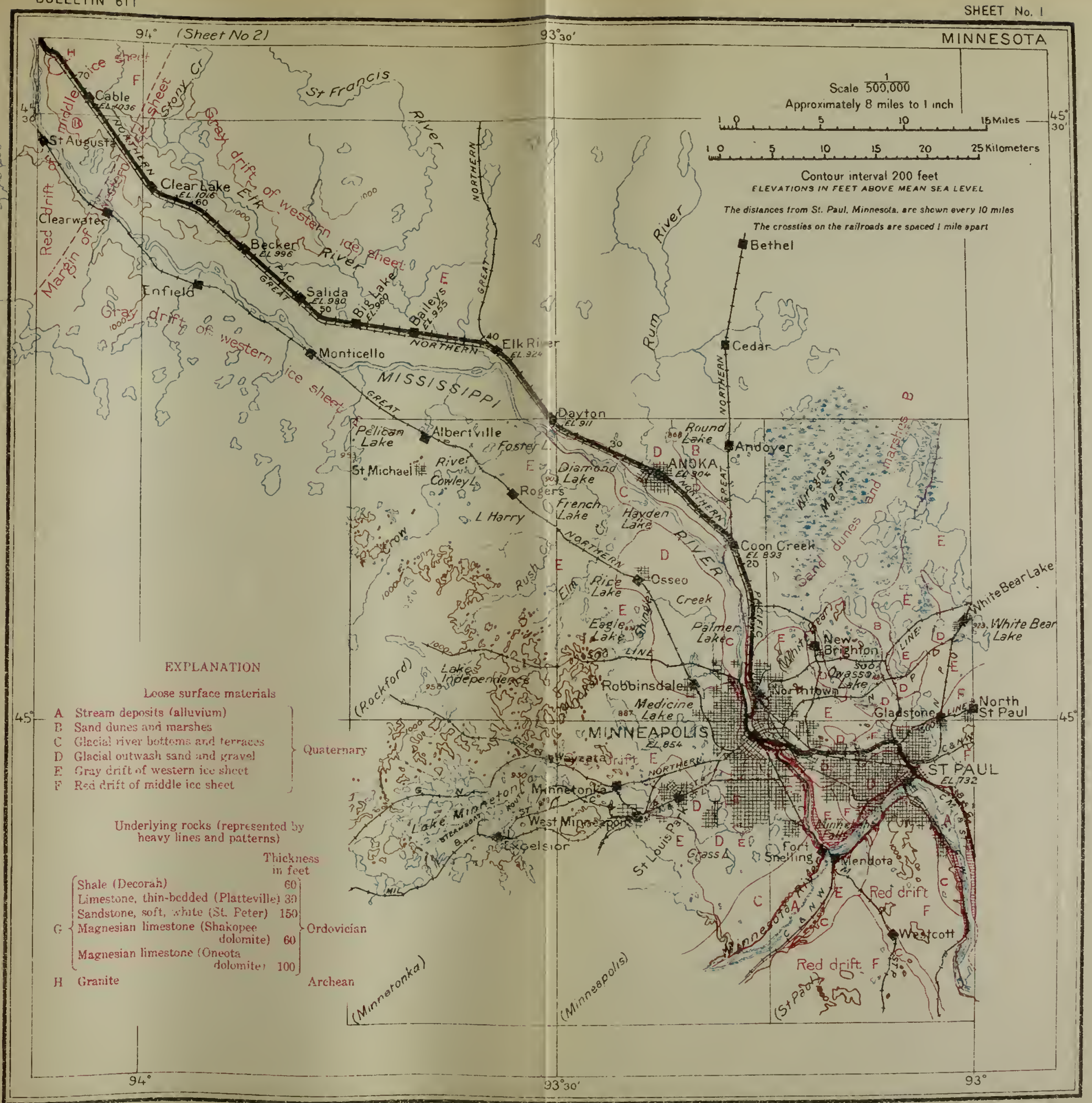



Between Watab and Rice the railway runs in a flat valley that extends as far as the eye can reach. It is well cultivated, and the Rice.

Elevation 1,086 feet. Population 262. St. Paul 90 miles. fields of grain and potatoes are broken only by some small lakes that are to be seen on the right of the track, but these have low shores and are not particularly attractive. As the train glides through mile after mile of waving grain or pasture fields, with here and there a farmhouse nestling beneath the shadow of some ancient oak, it is hard to realize that a little more than a century ago this was a wilderness in which roving bands of Indians found only a scanty subsistence and trappers and traders made journeys with the greatest hardship and discomfort.

Although there are no exposures of rock between Rice and Royalton, the route map opposite page 26 shows many isolated outcrops

\section{Royalton.}

Elevation 1,103 feet. Population 676 . St. Paul 97 miles. of granite and slate; and it will be noticed that all the areas of granite lie east of a line passing nearly through Royalton and that all the hard rocks which appear at the surface west of that line are slates or schists (for definition see footnote on p. 155) with the exception of one exposure of Cretaceous shale on the west side of the river nearly opposite Royalton.

A short distance beyond milepost 95 a branch of the Soo Line (Minneapolis, St. Paul \& Sault Ste. Marie Railway), extending from Brooten to Duluth, crosses the valley and the Northern Pacific track by a long, high fill. North of Royalton, on the right, some rather prominent morainic hills give a pleasing variety to the landscape; and at Gregory the traveler is about opposite the point where Pike's party spent the winter of $1805-6$.

vates. He found settlements and villages as far up the river as Prairie du Chien, but above that place there was no white settlement and only scattered trading posts of the various fur companies. He reached the mouth of St. Peter (Minnesota) River on September 21, and spent some time visiting the Indians and acquiring for the Government the title to 100,000 acres of land, including the site of Fort Snelling and the Falls of St. Anthony.

He then portaged around the falls and proceeded up the river, but at many places he had considerable difficulty in getting his boats over the rapids. He finally reached the vicinity of Little Falls, but here the river was so rough that he decided it was useless to take the boats farther, so on October 16, 1805, he went into winter quarters on the west bank of the river about 4 miles below the present town of Little Falls.

Pike with a few companions pushed on afoot and endeavored to find the source of the great river. He succeeded in a general way in settling the question, though he did not discover Lake Itasca. Pike returned to Little Falls on March 6 , 1806, and on April 10 the entire party embarked once more, reaching $\mathrm{St}$. Louis on the 30 th. 
Taken all in all, the Mississippi Valley, in which the train runs from Minneapolis to Little Falls, is one of the richest and most attractive valleys in the State.

From Little Falls lead two branch lines of the Northern Pacific, one running up the east bank of Mississippi River to Brainerd and thence to International Falls, on the northern Little Falls. boundary of Minnesota, and the other turning to the Elevation 1,134 feet. Population 6,078 . St. Paul 107 miles.

left and running to Morris, near the western edge of the State. The falls in the river are produced by hard slate and schist and by diorite (molten material that was forced up and into the sedimentary rocks and that has since been consolidated, forming a hard, dense, dark rock) of Archean age. (See table on p. 2.) These rocks are not massive like the granite at St. Cloud and so they do not make good building material, but they are as hard or harder and form a persistent obstacle to the easy flow of the river. The falls are of great commercial importance, as they furnish 10,000 horsepower, which is utilized by sawmills having a capacity of 70,000,000 board feet of lumber annually, flour and paper mills, and an electric-light plant.

Here once lay the margin of a great evergreen forest that stretched wild and unbroken to Duluth and the falls of Sault Ste. Marie, but now only a few pine trees can be seen here and there along the railway, for most of them have disappeared in the insatiable maws of the great lumber mills. Little Falls is noted among archeologists as a place where a large number of flint implements, belonging to an early race of men, have been found.

At Little Falls the traveler crosses Mississippi River for the last time in his westward trip; he will soon pass out of the Mississippi drainage basin and enter another whose waters find an outlet to the north. After leaving the river the train passes through a country that is typically glacial in all its features. The hard rocks are covered by drift varying in thickness from 35 to 400 feet. Owing to this thick cover the present surface of the ground gives no indication of what is beneath, and for many years it was supposed that this swampy country, covered only with brush and scrub oak, was of no value whatever. After some of the great deposits of iron ore in Minnesota and Wisconsin had been exploited it was found that the best way to prospect for iron ore in this region was with the magnetic needle. Many parts of Minnesota were tested unsuccessfully, but in 1895 it was found that the magnetic needle was affected in this area, and drilling has shown that it is underlain by a large body of iron ore. 'This deposit is now known as the Cuyuna (ki-you'na) iron range and is one of the three important iron ranges of the State. This range (see map of Cuyuna 
range on sheet 2 , p. 26), as now prospected and developed, extends from Aitkin, about 27 miles northeast of Brainerd, Randall.

Elevation 1,200 feet. Population 195. St. Paul 118 miles. southwestward to the vicinity of Randall. It is about 55 miles long, but its width has not been fully determined. No mining is done near this line of the Northern Pacific Railway, but several mines are operated some 40 miles to the northeast. ${ }^{1} \quad$ Little farming is carried

${ }^{1}$ Whoever wishes to see something of iron mining in Minnesota should make a short trip from Little Falls or Staples to Crosby or Ironton, on the Duluth line. The Pennington mine, which is within easy walking distance of either of these towns, consists of a large open pit from which the glacial drift was first stripped away and the ore then mined by steam shovels. The ore is hematite, an iron oxide, and has resulted from the deep weathering or decomposition of a slaty sedimentary rock that was originally rich in iron carbonate. The sedimentary rocks strike about $\mathrm{N} .50^{\circ} \mathrm{E}$., are folded closely, and dip at high angles. The workable deposits are vertical or steeply dipping lenses, which generally have a maximum width of 400 or 500 feet and an average depth of about 300 feet, but the maximum known depth is about 1,000 feet. Some of the lenses extend for more than half a mile along the strike. The ores, some of which are soft and some hard, are in the main non-Bessemer-that is, they contain too much phosphorus to be converted into steel by the Bessemer process, which is one of the processes generally used. Some of the ores contain considerable manganese.

The traveler wishing to make a more extended excursion into the iron country may go from Little Falls or Staples to Duluth and take either the Duluth, Missabe \& Northern Railway or the Duluth \& Iron Range Railroad to one of the great iron-producing towns on the Mesabi range. This range is about 100 miles long and 1 to 3 miles wide. The most productive part is served by a trolley line which runs between Hibbing and Eveleth, making all the mining towns between easily accessible. The HullRust open pit at Hibbing is the largest iron mine in the world, producing in 1913 nearly $3,500,000$ long tons of ore. A description of the iron ranges is given by W. H. Emmons, State geologist of Minnesota, in the following paragraphs:

The iron ore of the Mesabi (me-sah'be) and Cuyuna ranges is contained in the Biwabik (be-wah'bick) formation, named from one of the iron-mining towns in the Mesabi range. This formation consists of ferruginous cherts, iron ores, slates, iron silicate, and carbonate rocks, with a small amount of coarse detrital material at its base. It grades upward and in places laterally into more slaty rocks, known as the Virginia slate; and it is underlain by the Pokegama quartzite, consisting mainly of quartzite but containing also conglomerate at its base. These three formations are generally known as the Animikie (a-nim'i-kee) group and belong in the upper part of the Algonkian system as exposed in this region. All these rocks were laid down after the close folding which affected the lower Algonkian rocks, consequently the formations of the Animikie group are not on edge but generally dip at low angles.

The Biwabik or iron-bearing formation extends along the Mesabi range (see map on sheet 2, p.26) for its entire length. Its average thickness is about 800 feet, but owing to the prevailing low dips the width exposed varies from a quarter of a mile to 3 miles. The great bulk of the formation is ferruginous (iron-bearing) chert, with varying amounts of amphibole (asbestos), some lime and iron carbonates, and bands and shoots of iron ore. Associated with the chert, mainly in the middle zone, is the iron ore, which occupies about 5 per cent of the total surface area of the formation. Throughout the iron-bearing formation, particularly in its upper part, 
on in this region, and the country is covered with a dense growth of scrub oak.

For some distance beyond Randall the country consists largely of swamps and scrub-oak uplands, but north of Cushing the surface becomes rougher, consisting of knoblike hills with

\section{Cushing.}

Elevation 1,288 feet. Population 313 ** St. Paul 123 miles. swamps or lakes between them. When seen from some commanding eminence the country appears to be a maze of more or less regular conical hills among which the railway turns and twists to find a level pathway. As the traveler proceeds he will note that the depressions between the hills become more pronounced, and when he is within a mile of Lincoln, or at milepost 126, he can see on his right one of the largest depressions in the region, occupied by Lake Alexander. Evidently the character of the submerged surface is much the same as that around the lake, for the surface of the lake, although extensive, is broken by morainic islands that add greatly to the charm of the scene.

The rough topography reaches its culmination near Lincoln, where the hills range in height from 100 to 150 feet and are very steep. As described in the footnote on pages $26-30$, the morainic Lincoln. material forming these hills was brought by a great Elevation 1,304 feet. glacier (the middle ice sheet) that pushed into this St. Paul 129 miles.

region from the northeast. It extended only a little beyond Mississippi River, and the rough topography about Lincoln is due to the deposition of a part of its terminal moraine.

Lincoln is mainly a summer resort and is an attractive place for those who enjoy boating and other aquatic sports. The wooded

are thin layers of slate and paint rock, the paint rock usually resulting from the alteration of the slate.

At the east end of the range, near Birch Lake, the iron formation has been considerably metamorphosed in consequence of the intrusion of granite to the north and of gabbro to the south. As a result considerable amphibole has been developed in the ferruginous rocks, magnetite has segregated into layers, and the rocks have become hardened.

Thin beds of conglomerate and shale of Cretaceous age, lying nearly horizontal, cap the various Algonkian and Archean formations. The basal beds of the Cretaceous locally carry detrital iron ore derived from the weathered Biwabik formation.

Only small portions of the Biwabik formation are rich enough to constitute iron ore. These occur in isolated masses along the eroded surface of the formation and are generally not over 200 feet thick, although some are thicker. The workable deposits are secondary concentrations due to the action of surface waters, which have leached out the silica and some other elements and have left the iron in a more highly concentrated form. Concentration of this nature, in places to which water solutions have found more ready access, has been going on through long geologic periods. That it was well advanced in Cretaceous time is shown in the detrital zone of the Cretaceous rocks, in which iron ore is abundant in the form of polished pebbles.

The geologic conditions in the Cuyuna range appear to be almost identical with those in the Mesabi range, described above, but as the Cuyuna range has been only slightly developed its geology can not yet be described in detail. 
islands in Lake Alexander afford an almost unlimited number of camping places and sites for summer cottages.

The strong morainic topography continues for several miles beyond Lincoln but gradually becomes more subdued, and even the gently rolling ground that is noticeable around Phil-

\section{Philbrook.}

Elevation 1,269 feet. St. Paul 135 miles. brook soon gives place to a country that is flat and swampy as far as the eye can see. Philbrook is supposed to stand on the dividing line between the red drift of the middle ice sheet and the gray drift of the western sheet, but no distinction between the two drift sheets can be observed from the car window.

From Philbrook the land continues flat and swampy to Staples, which is a division point and one of the main junctions on the

\section{Staples.}

Elevation 1,298 feet. Population 2,558. St. Paul 141 miles. railway. Here the line from St. Paul joins the original main line of the Northern Pacific from Duluth. ${ }^{1}$ The country west of Staples is as flat as that to the south, over which the traveler has just passed,
${ }^{1}$ As early as 1853 the Government made a survey to determine the best location for a Pacific railroad, and one of the routes examined and recommended is practically that which the Northern Pacific follows, but after the survey was made the undertaking seemed so great that capital could not be found with which to make even a beginning. On the completion of the Union Pacinic Railroad in 1869 the faith of the public in the success of transcontinental roads seems to have revived, and in 1870 the construction of the Northern Pacific line was actually begun. Work was started at the two extremitiesnear Duluth, which was to be the eastern terminus, and between Kalama, on Columbia River, and Tacoma, the western terminus in Washington. In Minnesota the rails were laid in 1870 as far as Brainerd, on Mississippi River, 30 miles east of Staples, and in 1871 were extended entirely across the State.

At that time Duluth, on account of its location on one of the Great Lakes, was considered the most desirable place to connect with the East. Duluth is a convenient port for the westward traffic in coal and other heavy materials and for grain shipments eastward to the seaboard, but it then stood in a great wilderness, without railway communi- cation and at the head of a lake closed to navigation by ice for five months of the year. The Northern Pacific Co. early recognized that water transportation was losing its importance and that in the future St. Paul, with its unlimited possibilities of railroad connection with Chicago, was the natural eastern terminus of the road. Accordingly negotiations for a line to St. Paul were undertaken.

Sometime between 1864 and 1870 a railroad was built from St. Paul up Mississippi River to Sauk Rapids by an independent company. This line was purchased by the Northern Pacific Co. in 1870 with the understanding that the road was to be completed to Brainerd, where it would connect with the main line of that system. In the panic of 1873 the Northern Pacific could not fulfill its obligations and so lost control of this line. The road was completed to Brainerd on November 1,1877 , by other persons, and it afforded the first railroad connection between the Northern Pacific line and the cities of Minneapolis and St. Paul. The Northern Pacific Co. leased this line in 1878 and later acquired control of it through the purchase of its capital stock. Still later the company built the road from little Falls to Staples, giving it the through connection desired. 
and as far as the eye can see there are no hills to break the monotony of flat and swamp. The railway follows, in general, the valley

Aldrich.

Elevation 1,351 feet. Population 586.*

St. Paul 148 miles. of Leaf River, which lies north of the track. Like most of the other valleys of this region, this one has not been carved by the stream that occupies it but is merely a chain of low places along which the water finds an outlet. Such valleys have no definite shape or plan; and consequentlyat one place the railway may be in a fine rolling Verndale.

Elevation 1,369 feet. Population 538. St. Paul 152 miles. country that is well farmed and prosperous, as it is at Verndale, and at another place it may be in the most dismal expanse of swamps and shallow lakes.

In a general way the country becomes more rolling toward the west, and about the town of Wadena (see sheet 3, p. 32) there are fine farms on both sides of the railway. When the

\section{Wadena.}

Elevation 1,372 feet. Population 1,820. St. Paul 159 miles. crops wave green in the breeze or take on the golden tints of harvest time this country affords the traveler a pleasing contrast with the swamps and scrub oaks of the region to the east. Just east of the station at Wadena the Northern Pacific is crossed by a line of the Great Northern which runs from Sauk Center to Cass Lake, and about 2 miles west of Wadena a branch line of the Northern Pacific turns to the left and runs to Fergus Falls and Breckenridge.

Near milepost $169^{1}$ the railway approaches Leaf River on the right, and near the valley there is more decided evidence of morainic topography than there is between this point and

Bluffion.

Elevation 1,344 feet. Population 148. St. Paul 164 miles.

Staples. The hills are not high, but they have the peculiar conical or sugar-loaf shape that characterizes morainic hills, and they are separated in many places

by marked kettles or depressions. The hills in this region are formed of material that the ice brought in from the Red River valley. A brief history of the several invasions of Minnesota by the ice and a description of the drift deposited by them is given below by Frank Leverett. ${ }^{2}$

${ }^{1}$ Mileposts on the Northern Pacific are numbered from division points and not from the ends of the system.

2 Before the glacial epoch, or Great Ice Age, Minnesota presented a very different appearance from that which it presents to-day. Where there are now flat plains there were then rocky hills and ridges, separated by deep valleys. In the central and western parts of the State, from the Minnesota Valley northward, the bedrock is deeply buried. Deep drilling shows that it has an uneven surface and is composed chiefly of old crystalline rocks in which there are differences of altitude of at least 500 feet. In the northeastern part of the State the iron ranges and their associated rock formations stood out much more prominently than they do to-day. This old surface is now so deeply buried under glacial material in the greater part of the State that it is not possible, with our present knowledge, to outline the position and courses of even the principal streams of that time. Of the eastern and southern 

West of Bluffton the morainic character of the topography continues for some distance but gradually gives place to the rolling country about New York Mills. The less broken New York Mills. country here is well suited to agriculture, and fine Elevation 1,433 feet. farms may be seen on both sides of the track.

Population 474.

St. Paul 172 miles.

The railway is here on the divide between the Hudson Bay and Mississippi River drainage systems. It is not at all certain that before the glaciers covered this country the divide was at this place, as all the stream courses have been either materially modified or completely rearranged by the ice sheets that invaded the State. The present divide is not made evident by any well-marked ridge, and the appearance of the country will not probably show the traveler that he is crossing from one of the great drainage basins of the continent to another. 'The figures given for the elevation of the towns show that New York Mills is a little higher than the towns on either side and hence that the water parting is near that place.

At milepost 187 the railway crosses Otter Tail River, the first large stream passed in the Hudson Bay drainage basin. This stream has its origin in a number of beautiful lakes near the Northern Pacific line and flows southward through Rush Lake to Otter Tail Lake, the largest body of water in the region. Thence it flows westward and joins the Bois des Sioux at Breckenridge, forming Red River.

After crossing Otter Tail River, which meanders broadly in a swampy bottom about a mile in width, the railway traverses a rolling plain of rich agricultural land near the center Perham.

Elevation 1,390 feet. Population 1,376. St. Paul 182 miles. of which stands the prosperous town of Perham, so named for the first president of the Northern Pacific Railroad Co. The surface of this plain is formed of sand and gravel washed out from the front of the western ice sheet as the big moraine to the west and north was veing deposited. Pine, Little Pine, and Marion lakes lie a few miles from the track on the right, and the cottages and hotels along their

parts, however, enough is known to warrant the statement that the positions of the preglacial stream courses were not widely different from those of to-day. The Mississippi flows locally in a new ourse past St. Anthony Falls, at Little Falls, and at Sauk Rapids; but drilling has shown that a deeply buried valley, which is 200 feet or more below the present stream, lies near the river and in places crosses it.

The glacial epoch did not consist simply in the growth and disappearance of a single great continental glacier; there were stages of great extension of the ice, separated by stages in which it was greatly reduced if not entirely melted away. There were also several centers of exceptionally great snowfall and snow and ice accumulation, from which the ice radiated or flowed outward. From three of these centers of dispersion the ice spread into Minnesota in the Wisconsin stage. (See map on sheet 3 , p. 32.) The western and southern parts of the State were covered by ice 
shores offer many inducements to the sportsman or to the summer visitor who is in search of relaxation from the breathless hurry of . modern city life.

The plain extends along the railway to a point 4 miles northwest of Perham, where it gives place to rough, hummocky land that marks an eastern point of the great morainic ridge on the west of the track. When this moraine was formed the ice had disappeared from the country to the east but covered all that part of the State lying to the west. From Luce to Frazee the ground is generally swampy or dotted by small lakes or ponds.

At milepost 196 the railway crosses Otter Tail River, here flowing to the east. On account of the numerous ridges this stream wanders about from lake to lake, finding an outlet by an exceedingly roundabout course. Only a few of these lakes are visible from the train,

(western ice sheet) which came from central Canada. The eastern part as far south as the vicinity of St. Paul was covered by ice (middle ice sheet) from the region south of Hudson Bay, and a small area on the border of the Lake Superior basin was covered by ice (Superior ice sheet) which came in from the east through that basin. The western sheet brought in fragments of limestone and shale, the middle sheet carried southward much material from the iron ranges and also red sandstone from the west end of Lake Superior, and the eastern or Superior sheet transported to the limits of its advance large amounts of the red sarrdstone bordering that basin.

The effect of these invasions was to fill up and obliterate the valleys or to block them in such a manner as to produce chains of lakes along their courses. Large moraines or irregular, hummocky ridges of drift mark successive positions of the border of each of the ice sheets. Sand and gravel were spread out by water escaping from the ice front, fringing the moraines in extensive plains termed outwash aprons. In places where the ice border melted back rapidly no moraines were formed, but instead a nearly level surface, composed of bowlder clay or till.

The moraines of the Superior sheet encircle the west end of the Lake Superior basin in a series of concentric ridges, each ridge being later than the one without and earlier than the one within. Those formed by the western ice sheet lie in the high country along the valleys of Red River and Minnesota River. These streams are bordered by broad plains which owe their form to the fact that they lay under the deep part of the ice sheet and along its axis of movement.

The moraines of the middle ice sheet are well developed south and east of St. Paul and in central Minnesota. The Northern Pacific Railway traverses one of the most prominent moraines of this ice sheet, between Little Falls and Staples. The three advances of ice, though occurring in a single glacial stage, did not take place at the same time. After the middle sheet reached its maximum and melted back nearly if not quite to the Canadian line, the other sheets advanced into the district it had occupied and there covered its drift with their deposits. The western ice in places extended 75 miles or more into the district the middle sheet had abandoned.

The map on sheet 3 (p. 32) is intended to show the several glacial invasions of Minnesota during the Wisconsin stage, but as the three glaciers did not invade the State at the same time it is impossible to represent them accurately on a single map. The extent of the middle sheet is known only from the drift it deposited, and as much of this is covered by material brought in later by the western sheet its limit on the west can be only conjectured, but it probably covered much of the northern part of the State. 
but the map shows that great numbers of them lie on both sides of the road. The kettle-like depressions in a moraine, many of which

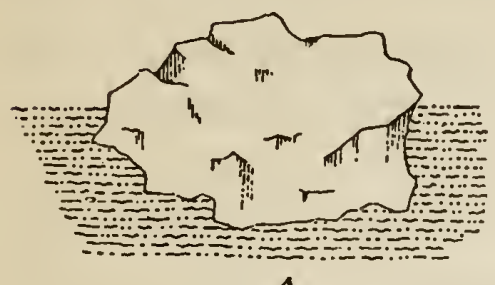

A.

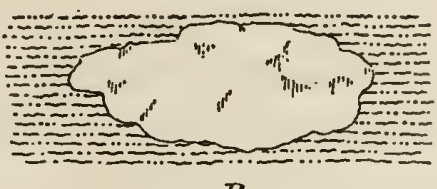

$\boldsymbol{B}$

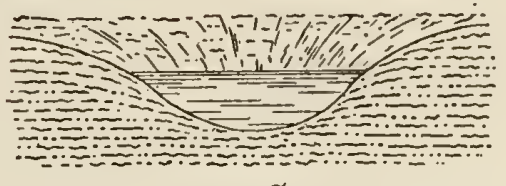

C

FIGURE 3.-Diagram showing probable origin of many kettle holes. $A$, Block of ice recently broken from a glacier; $B$, same block after part has been melted and the remainder covered with sand and mud; $C$, depression resulting from complete melting of the ice.

are filled with water and become ponds or lakes, are due either to irregularities in the deposition of the drift along the front of a glacier or to the melting of detached blocks of ice. ${ }^{1}$

The map is supposed to represent the State as it was when the western ice sheet extended southward along the Red River valley and deployed to the east into the open lands of Minnesota. Part of this great glacier found an outlet eastward into the upper Mississippi Valley and the valley of St. Louis River, but the main mass of the ice pushed southeastward along the valley of Minnesota River. A part overflowed northeastward, forming a lobe that covered much of the territory north of St. Paul. The main lobe swept on southward across the boundary of the State and as far as Des Moines, Iowa. After a time the melting at its front exceeded the supply of fresh ice coming from the north, and then the glacial margin began to retreat, and eventually the ice disappeared from the State.

When the ice of the Superior sheet melted back into that basin the ponding of water between the ice front and the highland bordering the basin formed a glacial lake, known as Lake Duluth, which discharged into the St. Croix Valley, in northern Wisconsin. Similarly, as the ice melted in the Red River valley, a lake known as Lake Agassiz (see p. 32) formed between the front of the glacier on the north and the high land to the south and discharged to the south through Browns Valley.

Over a large part of the surface of the drift of Minnesota there has been little change since the ice disappeared except the formation of soil and a slight leaching and weathering; but in some places notable changes have been wrought. Many of Minnesota's "ten thousand lakes" show beaches at higher levels than the present, their outlets having been cut down by the water at various stages. Many lakes have been so filled with sediment as to become marshes or even dry land, and many have been filled by the growth of peat. St. Anthony Falls, on the Mississippi, has retreated a few feet a year until recently checked by an artificial retaining wall. Minnehaha Falls, on a small tributary of the Mississippi, has retreated less than 400 feet in several thousand years. On the whole, the amount of stream erosion since the last glaciation is slight, and on many streams it is scarcely enough to be measurable.

${ }^{1}$ When a glacier reaches its greatest extension and begins to retreat, its pause and recession mean that the supply of fresh ice or snow back at the gathering ground, where it receives most of its material, is not sufficient to keep pace with the melting that goes on over its ontire surface, but more particularly at its outer margin. The result is that the ice near the extremity moves forward very slowly and finally ceases to move at all. The edge of the ice sheet becomes thin and irregular, and, owing to more rapid melting along cracks or crevasses, masses of ice become separated from the main body.

Part of such a block, as shown at $A$ in figure 3 , above, may be uncovered, but 
Near Frazee the surface is rough and broken and there are many deep valleys containing lakes, ponds, or swamps. A notable depression or old channel is crossed by the railway just

Frazee.

Elevation 1,410 feet. Population 1,645. St. Paul 194 miles. southeast of the town. This channel extends northwestward from Murphy Lake, 2 miles southeast of Frazee, and it is generally occupied by swamps or long, narrow lakes. The railway follows it for 3 miles beyond the town, and some of the views of the little lakes on both sides of the track are very pretty. Town Lake, close to Frazee, and Harold Lake, farther on, are in this channel on the left (south) of the track; and Chilton and Brink Lakes are irregular bodies of water on the other side.

Frazee is in the heart of a lake region, where large lakes abound on all sides of the town, but none of them are visible from the train for several miles beyond Harold Lake. It is also in a great morainic belt, which was formed by the ice sheet (western) that invaded this country from the Red River valley. The hills are steep and conical, and the depressions between them are very pronounced. To this glacier is largely due the lake region of central-western Minnesota, well known as a summer resort and as a paradise for sportsmen.

The largest and best-known sheet of water that is visible from the train in this vicinity is Detroit Lake, which can be seen on the left as the train skirts its banks between mileposts 208 and 209, a short time before reaching the station at Detroit. From Detroit Lake a river channel leads southward into and through a series of other lakes of equal beauty. This channel has been made navigable by a system of locks, and small steamers ply from lake to lake, passing the finest scenery of the lake region. The drinking water used on Northern

Detroit.

Elevation 1,386 feet. Population 2,807.

St. Paul 203 miles. Pacific dining cars comes from Pokegama Spring, on the shore of Detroit Lake.

Detroit is one of the most important towns in the lake region, and is a point of departure for many of

possibly the larger part will be buried in sand and gravel washed out from the front of the glacier. In the course of time the part above ground melts and disappears, but if the deposition of sand and gravel continues the part below the surface may become completely covered, and being protected it persists, as shown at $B$ in figure 3. Finally this also melts, and the surrounding sand and gravel fall into the hole left by the ice. This leaves such a depression as that shown in the diagram-a kettle, as it is generally called in a glaciated country.
If the material surrounding the kettle is open and porous, and if there is good underground drainage, the kettle may remain open and in much the same condition as it was when it was formed; but if the earth around the kettle is impervious, then most of the water falling into it or draining into it from the surrounding region is retained, and a lake or pond is the result. Some of the lakes of this region are many miles across, and if their basins were formed in this way the blocks of ice that caused the depressions in which they lie must have been correspondingly large. 
its resorts. Just west of the town the Northern Pacific is crossed by a branch of the Soo Line (Minneapolis, St. Paul \& Sault Ste. Marie Railway), which runs from Alexandria to Plummer.

The roughest part of the moraine seen from the railway, a part known as the Leaf Hills, lies east of Detroit, but west of that place the surface features become more and more subdued.

Audubon.

Elevation 1,332 feet. Population 300 .

St. Paul 210 miles.

As the morainic topography disappears farming becomes more general, and at Audubon field after field of grain stretches away over the rolling upland as far as the eye can see. Although the traveler may have enjoyed the ever-changing panorama of lakes, hills, and plains of the morainic belt, he may find it a relief to emerge into the fine farming region about Audubon and Lake Park.

Lake Park is another important town of the lake region, and although no water is visible from the train there are one or two ponds near by, and some of the finest lakes of

Lake Park.

Elevation 1,341 feet. Population 740.

St. Paul 216 miles.

the region lie a short distance to the south. Lake Park is on the edge of the prairies. The trees are small and are confined largely to the watercourses. Almost all the land is under a high state of cultivation, and fields of wheat and hay abound on every side.

The country here is a gently rolling upland with the valleys cut to a depth of 50 feet or more below the general level. At Manitoba Manitoba Junction. Junction the Northern Pacific line running to Crookston, Minn., Grand Forks, N. Dak., and Winnipeg, Canada, turns to the right (north). At this place the traveler enters the valley of Buffalo Creek Elevation 1,228 feet. St. Taul 224 miles.

and can not see the upland country, which, however, is much the same in character as the country east of the junction-that is, it is rolling, but is cut by the valleys of the larger streams.

\section{Hawley.}

Elevation 1,174 feet. Population 800.

St. Paul 228 miles.

The railway follows Buffalo Creek through the village of Hawley, but the valley grows deeper toward the west, and little of the country outside of the immediate valley can be seen from the train. If the traveler had been attempting to cross the continent in the closing stages of the glacial epoch by the route which he is now fol-

\section{Muskoda.}

Elevation 1,087 feet. St. Paul 234 miles. lowing, he would have been confronted, when he reached the place where Muskoda now stands (see sheet 4, p. 40), by a vast lake which then occupied the valley of Red River. The only passageway around it would have been by a wide detour to the south, for the lake extended into Canada for several hundred miles and was bounded on the north by the impassable front of the great continental glaciel. As the lake has completely disappeared the reader may be skeptical about its existence or wonder upon what evidence its presence in a 
former age has been determined. Unfortunately the track is so far below the general surface of the upland that there is little opportunity to observe details, but if the traveler could carefully examine the ground he would easily recognize the shore of this ancient lake just before he reaches the station at Muskoda. This old shore consists of a ridge of gravel which was heaped up by the waves that beat upon its western side. The large gravel pit which the railroad has excavated in this ridge to procure ballast can be seen from the Muskoda station.

The lake was named by the geologist Warren Upham in honor of Louis Agassiz, who was the first to make a systematic study of glaciers and glacial phenomena." The beach at Muskoda is called

${ }^{1}$ Lake Agassiz was a body of fresh water that existed during a late stage of the glacial epoch in the valley of Red River and extended northward (see map on sheet $4, p .40$ ) from the head of that stream for nearly 700 miles. The area of the lake at the time of its greatest expansion was about 110,000 square miles, exceeding the present aggregate area of the five great lakes tributary to the St. Lawrence.

The shore of this ancient lake is marked by well-defined beaches, and it is from these that the existence and the extent of the lake are known. The beach ridges are built upon typical bowlder clay, and hence it is known that the lake either followed the invasion of the ice or marked the closing stages of that episode.

The next question that arises is, What were the conditions that led to the formation of such a lake? It could not have been held in a landlocked basin, for no such basin exists at the present time, and there is no evidence that the surface features of that time differed, greatly from those of to-day. Warren Upham, who has studied this question most carefully, has come to the conclusion that it was held in place by the retreating front of the glacier, which blocked the natural outlet of the water to the north and forced it to accumulate in this basin. The ponding of the water in the Red River valley began as soon as the ice front retreated across the divide at the head of Lake Traverse, and the water found an outlet down the valley of Minnesota River, in a stream that has been called Warren River.
Lake Agassiz thus began as a small body of water and expanded northward as the ice melted until it became of great extent.

The water of Lake Agassiz continued to flow through Warren River until the Keewatin (ke-way'tin) ice had melted back northward far enough to permit an outlet eastward, perhaps at first to the Superior basin, but later to Hudson Bay. Recent studies have shown that the growth of Lake Agassiz was dependent upon the retreat of the western ice sheet. (See map opposite this page.) The moraines of this ice sheet that mark the successive positions of the ice border indicate two positions, marked $\mathrm{A}-\mathrm{A}$ and $\mathrm{B}-\mathrm{B}$ on the map opposite page 40 , with a fair degree of accuracy. The later positions, $\mathrm{C}-\mathrm{C}$ and $\mathrm{D}-\mathrm{D}$, are drawn to correspond with the topography. The western limits of Lake. Agassiz have been determined with considerable accuracy, but the eastern limits in Canada are in a forested region that has not been explored sufficiently to determine the extent of the lake. Apparently lower eastward outlets were opened successively as the ice retreated northward, for 31 shore lines were formed as the lake was drawn down to lower levels. All the outlets have not been mapped. It seems likely, however, that there was no discharge to Hudson Bay until the ice had melted back beyond the position $\mathrm{C}-\mathrm{C}$, but there may have been an outlet into the Superior basin before the ice had retreated so far north.

The shore lines are inconspicuous, but on the smooth slopes of the lake bed 

the Herman beach. It was formed when the water of Lake Agassiz stood at its highest level and consequently marks the line between the unmodified glacial topography above and the smooth surface of the old lake basin below. The difference in the topography may not be noticeable on the east side of the valley because of the unfavorable outlook, but on the opposite side of the valley west of Fargo the difference is very striking and can readily be seen from the train.

Between mileposts 242 and 243 the railway emerges from the now shallow valley of Buffalo River, and the traveler may obtain his first view of the famous Red River valley, which has been referred to frequently as the "granary of the world," but which was once a lake about 50 miles wide at this point and nearly 700 miles long.

they are generally easily traceable. The best-developed beach ridges of the lake commonly rise 10 to 20 feet above the adjoining land on the side that was next to the water and from 3 to 10 feet on the opposite side. They vary in width from 10 to 30 rods and are composed of interstratified gravel and sand, the gravel prevailing, including pebbles 2 to 4 inches in diameter.

The development of the beaches varies greatly from place to place, depending apparently upon the abundance and character of the materials which were within reach of the waves. Thus where the valley is crossed by the main line of the Northern Pacific Railway three beach ridges are clearly visible on the east side of the valley and two on the west. At Wahpeton (waw'pe-ton), on the Fergus Falls branch of the same road, there are four well-developed ridges on each side of the valley. At Grand Forks there are four ridges on the east, where they are crossed by the Great Northern Railway, and twelve on the west.

The Herman beach, which marks the highest stage of the lake and which is the one most easily recognized, has been traced for a long distance around the south and west sides of the lake, but the lower beaches are not so well marked and can not be traced continuously.

Sand and gravel deltas, so extensive as to be notable features of the topography, were formed by several streams that flowed into the lake while it stood at its highest stages. The Buffalo River delta, down which the Northern Pacific Railway runs immediately west of Muskoda, covers an area about 7 miles long from north to south and 2 to $3 \frac{1}{2}$ miles wide from east to west. The delta plain, as shown in figure 4 (p. 34), is terminated about 3 miles west of Muskoda by a steep slope, like the face of a terrace, 25 to 40 feet high.

The floor of this ancient lake is apparently a level plain, although it really has a slight slope toward the middle and a gentle northward inclination of about a foot to the mile.

The several shore lines are not parallel with one another or with sea level, but all show an ascent toward the north or northeast. Thus the upper or Herman beach rises 175 feet between Lake Traverse and the international boundary, but the grade is not regular, being 35 feet in the first 75 miles, 60 feet in the second, and 80 feet in the third. The lower beaches show a similar though less pronounced rise. As these beaches must have been horizontal when they were formed, it is evident that the crust of the earth has been elevated toward the north, and as the beaches show divergence among themselves, it is certain that this upward movement in the earth's crust began when Lake Agassiz was in existence and continued for some time after it was drained.

$40063^{\circ}-$ Bull. $611-16-3$ 
The silt deposited in this lake gives the valley its wonderfully smooth surface and its great fertility. During the highest stage of the lake Buffalo River built just below Muskoda a delta of considerable size, and it is from this delta that the first view of the valley may be obtained. At a later stage, when the water of the lake was at a lower level, the waves cut away the front of the delta and greatly increased the natural slope of the valley side, as shown in figure 4. The railway engineers found difficulty in getting down this slope without loops and curves, so a long, high fill has been made which gives a uniform grade from top to bottom. ${ }^{1}$ 'The weight of the fill, however, proved to be too great for the soft mud at the bottom of the old

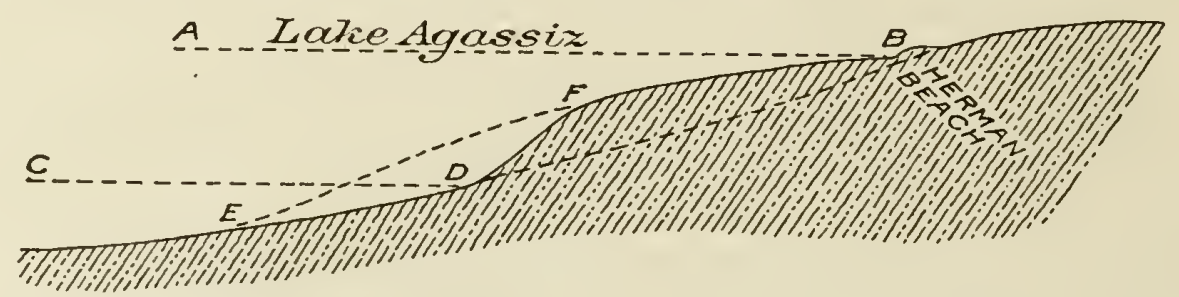

Figure 4.-Section of Buffalo River delta, Minn. $A B$, Surface of Lake $\Lambda$ gassiz at the Herman stage; $E F B$, delta profile; $C D$, level of water at Campbell stage; $E D F$, part of delta cut away by the waves, leaving the steep westward front $(D F)$.

lake bed, and it is still settling and throwing up a ridge of the soft material on each side.

From the high fill the traveler can see something of the great extent of the valley-its level floor stretching mile after mile without the least eminence or depression to break its regularity-and some of the fine farms that have made it famous. Drilling for water has shown that originally the surface of the valley was uneven, much like the country on both sides. At a later date the valley was filled by a great glacier that came down from the north, grinding and scouring away many of the projections and filling the depressions with the waste material; and then as the last smoothing process the fine mud carried by the streams settled in the lake, giving the valley its present smooth surface.

${ }^{1}$ In the original construction of the Northern Pacific Railway the standard maximum grade adopted was 52 feet to the mile except on the mountain sections, where the standard was 116 feet to the mile. As the traffic developed it was found necessary, for economy of operation and to increase the capacity of the line to handle the business of the country tributary to it, to adopt new standards of 18 and 21 feet to the mile except upon the mountain sections. This change necessitated a reduction in the original grades at many points, involving a large amount of expensive work, which has been going on actively for the last 15 years and is now nearly completed. The fill referred to in the text was constructed in connection with one of these reductions of grade. The grade was reduced from 48 to 18 feet to the mile, and freight-train loads were increased from 2,200 tons, with two locomotives to 2,550 tons with one locomotive. Many similar examples of grade reduction will be observed along the line. 
The material laid down in the waters of Lake Agassiz is so soft and fine that it is washed away with great rapidity when it is exposed to the action of the elements. Ordinarily the surface

Glyndon.

Elevation 946 feet. Population 295.

St. Paul 242 miles. vegetation protects it, but when this is removed disastrous results follow. In 1895 a wagon road was graded east of Red River and a short distance north of the railway near Glyndon for about 6 miles. The farmers at once began to drain their fields into the roadside ditch, which was deepened and widened so rapidly by the consequent erosion that in four years the road had been destroyed for nearly a mile and in its place there was a channel 80 foet wide and 25 feet deep.

Dilworth is a division terminal of the railway, established to relieve the congestion of the yards at Fargo, where the terminal was formerly

\section{Dilworth.}

Elevation 933 feet. St. Paul 248 miles. located. In the Red River valley. may be seen some of the magical effects of the mirage that is so striking a feature of an arid or semiarid region. Warren Upham describes it as follows:

The mirage, typical of plains country or the ocean, may be seen in the Red River valley almost any sunshiny day in spring, summer, or autumn. This queer phenomenon makes the high land at the sides of the valley, the tops of the distant trees, and houses appear to be raised a little above the horizon, with a narrow strip of sky between. The more complex and astonishing effect of mirage may be seen from the highland on either side of the lake-bed floor. There, in looking across the valley from one and one-half to two hours after sunrise on a hot morning following a cool night, the groves and houses, villages, and grain elevators loom up to two or three times their true height and places ordinarily hidden by the curvature of the earth are brought into view. Oftentimes, too, these objects are seen double, being repeated in an inverted image close above their real positions and separated from it by a foglike belt. In its most perfect development the mirage shows the upper and topsy-turvy portion of the view quite as distinctly as the lower and true portion.

These appearances are due to refraction and reflection from layers of air of different density, such as are often formed above a wide expanse of level country in warm weather.

The last town in Minnesota through which the train passes is Moorhead, named in honor of William G. Moorhead, a former director of the railway company. Between this town and Moorhead, Minn. Fargo, N. Dak., runs Red River, the boundary line Elevation 929 feet. Population 4,840. St. Paul 251 miles. between the two States, a deep, sluggish stream that is generally heavily charged with mud derived from soft materials deposited in the ancient lake. This mud gives to the water a brownish-red color. 
North Dakota comprises an area of 70,837 square miles. It was admitted to the Union in 1889, and at the census of 1910 it had a population of 577,056 . It is primarily an agricultural North Dakota. State, but from time to time, as conditions have changed, there has been a corresponding change in its leading industries. At the time of the first permanent settlement the whole State consisted of one vast open range which furnished grazing in abundance for the herds of wild animals that roamed over it. The white man saw the natural fitness of the region for grazing, and soon cattle, horses, and sheep were feeding in place of the deer and buffalo.

In the Red River valley farming early received a great stimulus from the officials of the Northern Pacific Railway, and before many years this valley, from its head to the Canadian line, was one vast sea of wheat. Farming was also carried on in other valleys to a minor extent, but for a long time the region west of Missouri River was considered suitable only for grazing, as the annual rainfall (16 inches) was thought to be too small for raising crops. The discovery in recent years that by proper methods of cultivation most of the moisture in the soil could be conserved and rendered available for agriculture has worked a wonderful change in the appearance of this country, for now almost all the land is under fence and the region west of Missouri River contains many fine farms and thriving towns.

The principal crops are wheat, oats, and flax, and the raising of domestic animals is still an important industry. According to the census of 1910 the value of all farm products for the year 1909 was $\$ 205,000,000$, of which $\$ 180,000,000$ was produced directly from the crops and $\$ 14,000,000$ from domestic animals. During the same year the value of manufactured products amounted to $\$ 19,000,000$.

North Dakota is well supplied with lignite. This is a low-grade fuel, but it is of very great value for domestic use on these treeless plains. Almost every section of land in the part of the State lying west of Missouri River is underlain by lignite, and it is estimated that the State contains 697,900,000,000 tons of this fuel. In 1913 the value of the lignite mined commercially amounted to $\$ 765,105$.

Fargo is the most important town in the Red River valley and the largest in the State of North Dakota. It was named for William G. Fargo, of Wells, Fargo \& Co.'s Express. Fargo is the Fargo, N. Dak. seat of the North Dakota Agricultural College and Elevation 926 feet. Experiment Station and is noted as one of the great Population 14,331. farm-machinery markets in the United States. The climate of Fargo is about the same as that of the Red River valley as a whole. The winters are frequently severe, the mercury registering $40^{\circ}$ below zero, and the summers are hot, ranging 
from $90^{\circ}$ to $105^{\circ}$. The mean annual precipitation is about 20 to 24 inches, compared with 28 inches at St. Paul and 15 or 16 inches in the western part of the State.

The Red River valley, including that part which lies in Canada, was one of the first to be explored in this part of the country. Lake Winnipeg, at its mouth, in Canada, was part of the great highway by which the French voyageurs penetrated the country west of Lake Superior in the early days of the trapper and trader. The earliest authentic record of exploration is that of Verandrye, who made an unsuccessful attempt to cross the continent in 1738-1742. French traders doubtless followed in his footsteps, but they left few if any records of their experiences or of the country traversed. In the early years of the nineteenth century David Thompson and Alexander Henry, of the Northwest Fur Co., pushed their way up the Red River valley into what is now North Dakota and Minnesota; and in 1812 the Earl of Selkirk made the first settlement in the vicinity of Winnipeg. Many French traders probably found their way south into that part of the Red River valley lying in North Dakota, for Lewis and Clark mention their presence on the Missouri as early as 1804 .

Not much is known of the rocks underlying the Red River valley, for they are effectually concealed by the glacial drift and by the sediment deposited in Lake Agassiz, but their presence here and there has been revealed by deep drilling. The deepest well which was sunk near Moorhead penetrated lake sediment and glacial drift to a depth of 220 feet, Cretaceous shale with some sandstone for 150 feet, and the underlying granite to a depth of more than 1,500 feet. This region is therefore near the eastern edge of the great mass of Cretaceous strata which extends as an unbroken sheet to the Rocky Mountains and which can be seen at many places along the Northern Pacific Railway. The sea in which these materials were laid down must at some stage of its existence have extended farther east than the Red River valley, for a few exposures of these rocks have been found in the valley of the Mississippi. (See route map, sheet 2, p. 26.)

A few years ago a traveler crossing the old lake bottom just-before the wheat harvest would have seen mile after mile of grain, which on a clear breezy day would have looked much like the waves rolling across the water, and he could almost have imagined Lake Agassiz to be still in existence. In recent years the crops in this region have become more diversified and now instead of the unbroken stand of wheat that stretched to the horizon line, the traveler sees interspersed with the wheat other grains and flax, and only here and there is the wheat grown in large areas. The rich black soil extends in almost unbroken regularity across the valley and it is under a high state of cultivation, even to the very edge of the railroad track. Probably there are few regions in the world in which the soil is more fertile than 
that of the Red River valley. The silt where it is wet and compacted has much the character of clay, but it differs from clay in that it contains fine sand, powdered limestone, and carbonaoeous matter, which make it less coherent.

There are some tracts of very compact and heavy soil upon the level bottoms, ranging in area from a few square yards to a few square miles, that are known as "gumbo spots." On account of the impermeable character of the clay, drainage is difficult and in places alkaline salts tend to accumulate.

West of Maple River, which the railway crosses near the village of Mapleton, the land rises steadily westward, but the surface of the old lake bed is so smooth and the ascent so regular that it is scarcely perceptible to the eye. This is a region of great Mapleton. farms, and one of the largest and most noted of these

Elevation 929 feet. Population 207. St. Paul 264 miles. is the Dalrymple farm, between Mapleton and Casselton, which comprises 21,000 acres of cultivated land. As these big holdings were the pioneers in the Red River valley and led directly to its agricultural development, their history may prove to be interesting at this place.

About 1870 the banking firm of Jay Cooke \& Co. became the financial agent of the Northern Pacific Railroad Co. and advertised widely the great agricultural possibilities of the region to be traversed by the railway. Its glowing statements were attacked through the press and otherwise, and much skepticism was expressed as to whether or not the country was of any value for agriculture. In order to meet these criticisms, oertain members of the Northern Pacific directorate determined that they themselves must furnish incontestable proof that the land could be farmed to advantage. 'T. H. Canfield purchased 5,500 acres at Lake Park, Minn.; Charlemagne Tower, 3,000 acres at Glyndon, Minn.; and Benjamin P. Cheney and George W. Cass, 6,000 acres at Casselton, N. Dak. These farms were at once put under expert cultivation, and the result of the experiment showed the Lake Park region and the Red River valley to contain some of the finest wheat lands in the world. The demonstration of this fact caused a large and steady immigration to this region in the years immediately following.

The town of Casselton is situated in the heart of the great wheat belt and was named for George W. Cass, a former president of the Northern Pacific Co. In the vicinity of Casselton and

Casseltion.

Elevation 961 feet. Population 1,553. St. Paul 272 miles. westward for some distance many flowing water wells have been drilled. These wells derive their supply from two sources-the glacial drift and the underlying Cretaceous rocks. The water obtained from the glacial drift is of fairly good quality and can be obtained at depths ranging from 40 to 200 feet, but the amount of water varies considerably 
and several of the wells have ceased to flow. The water from the Cretaceous rocks is slightly salty and not suited for irrigation, but can be used for domestic purposes. The depth of the producing wells ranges from 250 to 500 feet, and the flow of water is more constant than that from the glacial drift. The water-bearing rock is supposed to be the Dakota sandstone, which belongs at the base of the Upper Cretaceous. The water is supposed to enter the Dakota sandstone in Wyoming, where the sandstone is upturned against the Rocky Mountains, or in the region of the Black Hills. It follows the sandstone bed beneath the Great Plains and appears where the sandstone rises and approaches the surface in eastern North Dakota.

The village of Wheatland, appropriately named, is situated at the place where the railway crosses the lowest prominent beach of Lake Agassiz, the houses in the eastern part of the village

Wheatland.

Eleration 1,016 feet. Population 473.* St. Paul 278 miles. and a cemetery north of the track being situated on the beach ridge. When the surface of the lake stood at this level the water was 90 feet deep at Fargo, in the center of the valley, and it remained at this height long enough for the waves to heap up a distinct ridge of sand and fine gravel. This is known as the Campbell beach, from the town of that name in Wilkin County, Minn., through which it extends.

West of Wheatland there are, here and there, traces of similar beaches, showing that Lake Agassiz stood at different levels above

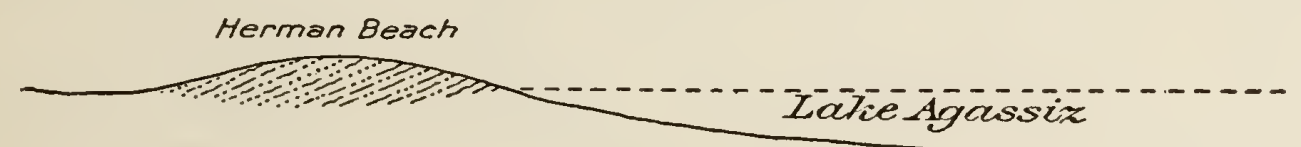

FIG RE 5.-Section of Herman beach ridge wast of Magnolia, N. Dak., showing the relation of the sand and gravel beds composing the beach to the surface of glacial Lake Agassiz.

that of the Campbell stage, but at none of them long enough to form a decided and well-marked beach, except at the highest of the series. This is known as the Herman beach. It can easily be seen from the train just 5 miles west of the Campbell beach, or three-fourths of a mile west of Magnolia. (See fig. 5.) This beach ridge is even better developed than the Campbell beach and is marked by an old gravel pit on the right (north) of the track. The ridge is 15 feet high and about 150 feet wide on top. In the pit the beds of gravel dip about $20^{\circ}$ to the west, or away from the open water of the lake, showing that the waves carried the sand and gravel over the top and deposited them on the back slope of the ridge. When Lake Agassiz stood at this level the water at Fargo was about 175 feet deep, but it rose no higher, because at that stage it found an outlet to the Mississippi through the valley of Minnesota River.

From the Herman beach a comprehensive view can be had of the broad expanse of the Red River valley. Above the level of the beach 
the old surface of till and outwash gravel is in its original condition, not having been smoothed and covered by a coating of mud, as was that of the submerged area.

West of the Herman beach the railway crosses a low, broad ridge by a deep cut in glacial tiil and sand. This cut is 4

Buffalo.

Elevation 1,226 feet. Population 241.

St. Paul 288 miles. miles long, extending as far as the village of Buffalo, and it affords excellent exposures of the materials transported by the ice. The low ridge through which the cut is made is a faint moraine, marking the position of the front of the glacier ${ }^{1}$ that occupied the valley of Red River before it became a lake, as described on page 32 .

${ }_{1}^{1}$ The glacial features of North Dakota are the result of the invasion of the ice sheet that originated west of Hudson Bay. At the time of its greatest expansion this glacier covered all of North and South Dakota east of Missouri River with ice probably hundreds and perhaps thousands of feet in thickness.

A study of the materials brought down from the north shows that glaciation was not confined to a single stage of growth and decadence of the ice sheets, but that there were several advances and retreats, and that the amount of movement accomplished in the various stages differed greatly. These fluctuations appear to have been due to the fact that at times the climate was favorable for the development and advance of the ice, and that at other times it was milder and the ice wasted away until large tracts previously covered were again in condition for the return of animal and vegetable life. During the warmer epochs soils were developed, and the glacial materials spread over the land were sculptured by newly established drainage systems. The return of colder weather and the advance of the ice over most of the area previously glaciated destroyed many of the new surface features and buried the whole under a new deposit of drift.

The extent of the several ice sheets which invaded the Dakotas during the Wisconsin stage of glaciation is shown on the sketch map on sheet 5 (p. 44). Northeastern Minnesota was covered by ice that came from the direction of Labrador. Sweeping southwestward and southward around the west end of this ice mass came another great glacier from the region west of Hudson Bay, which divided at the head of the Coteau des Prairies (for meaning of the word "coteau" see p. 45), or just south of the South Dakota line, into two great lobes, one of which, known as the Minnesota Glacier, passed southward up the broad valley of Red River and across Minnesota into Iowa as far as the present city of Des Moines, and the other, known as the Dakota Glacier, moved down the James River valley to the Missouri, spreadteau du Missouri. The farthest extent of these lobes is marked by a well-developed ridge, called the Altamont moraine.

The Altamont moraine is crossed by the Northern Pacific Railway between Sterling and Driscoll and from this point recedes far to the east, crossing the line between North and South Dakota about 75 miles east of Missouri River. In South Dakota its outline is somewhat irregular, showing that small lobes of ice pushed out here and there far beyond the principal mass. In general, however, the Altamont moraine bounds Missouri River on the east, and it is probable that the front of the ice and its accompanying moraine were largely instrumental in determining the course of that stream.

The Dakota lobe of the glacier filled all the country between Missouri and Big Sioux rivers, but east of the Big Sioux there was a strip of country free from ice, which extended, as shown on the map, nearly to the North Dakota line.

The marginal deposit indicating the first halt in the glacial wasting and retreat is the Gary moraine, which is ing westward upon the flanks of the Co- 


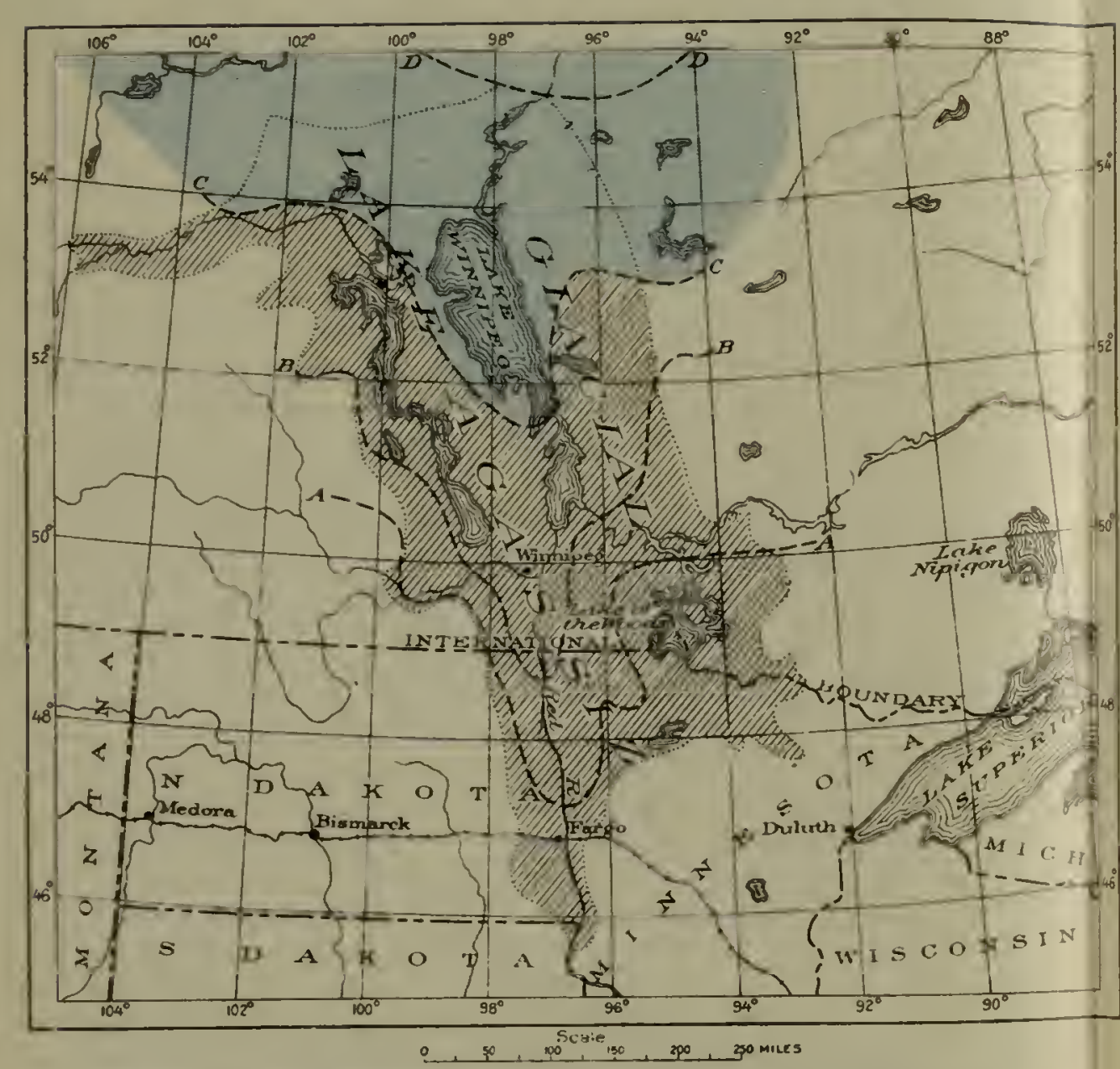

GLACIAL LAKE AGASSIZ SHOWING SUCCESSIVE POSITIONS OF THE RETREATING ICE DAM THAT HELD THE LAKE LAKE AREA BY UPHAM. ICE BORDERS BY LEVERETT





Just beyond Buffalo the traveler can obtain on the left the first extended view across the prairies and lowlands of the valley of Sheyenne River. 'This broad stretch of country is well farmed, and the fields of grain are a sure indication of its prosperity.

Near 'Tower City (see sheet 5, p. 44) the railway is located in a broad flat that is only imperfectly drained. by the headwaters of Maple River, as described on page 43 ; and then

Tower City.

Elevation 1,194 feet. Population 452. St. Paul 294 miles. begins the long, steady ascent to the summit of Alta Ridge, which can be seen in the distance from Oriska. This ridge, one of the most pronounced topographic features that will be seen between the Red River valley and Missouri River, is capped by drift which represents the crossed by the Northern Pacific Railway just west of Crystal Springs. It lies upon the Coteau du Missouri and is closely associated with the Altamont moraine, the high coteau front serving as a wall or dam which held back the ice in its forward movement. The great amount of material in these outer moraines and the large size of the hills indicate that the edge of the great ice sheet probably remained against the coteau for a considerable time. South of the Northern Pacific Railway the Gary moraine is roughly parallel with the Altamont moraine. In some places they coincide, but in others they are nearly 50 miles apart. The glacier at the time the Gary moraine was built extended as far south as it did during the greatest extension, but the lobe was narrower, averaging not more than 80 miles in width, and the point of division between this lobe and the Minnesota lobe had receded to the North Dakota line.

The next stage in the recession of the ice front is not marked by a single large and well-defined moraine, but by a belt of more or less disconnected ridges or heaps of morainal deposits, called the Antelope moraine. The number of these ridges indicates that the ice front fluctuated back and forth across the belt. The ridges of the Antelope moraine are crossed by the Northern Pacific line between Spiritwood and Eldridge, but they are not well marked on either side of James River. The glacier at the Antelope substage extended in a long tongue down the James River valley as far as Huron, S. Dak., but the point of division between the two great lobes had not changed its position appreciably from that which it occupied in the Gary substage. The Antelope moraine is here regarded as including the Kiester moraine, which has been recognized only for a few miles south of the Northern Pacific Railway and east of James River.

The next important moraine, which has been called the Waconia, is crossed by the railway between Eckelson and Fox lakes and forms the divide between Hudson Bay and the Gulf of Mexico. It marks the first definite and prolonged halt in the retreat of the ice front after the formation of the Gary moraine. The glacier at this stage of the retreat extended only a few miles across the State line into South Dakota, and its lobe, which at one time extended to the mouth of James River, was so reduced as to be scarcely recognizable and before the next halt had disappeared.

Two more halts in the recession of the western margin of the ice are recorded along the Northern Pacific line, but these were doubtless of slight duration and did not produce separate moraines south of the railway. The moraine marking the earlier of these halts is supposed to be the same as a moraine at Fergus Falls, Minn., and therefore is called by that name. It is well developed in Alta Ridge, 6 miles east of Valley City. The second moraine is the low ridge east of Buffalo. When the ice front retreated east of this moraine, the southern part of Red River valley became flooded with water, and Lake Agassiz was formed. 
Fergus Falls moraine. Its summit, which is crossed by the railway near milepost 59, attains an altitude of 1,454 feet, or 528 feet higher than Fargo on the east and 209 feet higher than Valley City on the west. On the west there is a sharp descent from Alta Ridge down to a broad plain formed by the outwash of material from the glacier when it lay just east of the ridge. It is supposed that at the time the moraine was formed Sheyenne River was flowing at the same level as this plain and that the present valley of that stream had not been cut.

West of Alta Ridge the old line of the railway turned slightly to the south and descended into the valley of Sheyenne River, crossing

Valley City.

Elevation 1,245 feet.1 Population 4,606 . St. Paul 310 miles. the stream but little above the general level of the valley bottom. Recently a new "high line" has been carried across the valley on a steel trestle 150 feet high. From this trestle a fine view of Valley City and the river can be had. (See Pl. III, p. 11.) Here the rock underlying the glacial drift is exposed, and it is the first exposure of this kind that can be seen from the train west of the Mississippi Valley. Soft dark shale may be seen in either bluff from the "high line" or in the sides of the coulee ${ }^{2}$ as the train descends by the "low line" to the bottom of the valley. This shale contains fossil shells, which are similar to those of animals living in the ocean of to-day; hence it is believed that it was deposited when this part of the country was beneath the waters of a sea. ${ }^{3}$

At Valley City the Northern Pacific is crossed by the branch of the Soo Line that connects Moose Jaw, on the main line of the Canadian Pacific Railway, with St. Paul.

1 This is the altitude at the old station, which is near river level. The new station is about 150 feet higher.

${ }^{2}$ The term "coulee" is generally applied throughout the northern tier of States to any steep-sided gulch or water channel and at times even to a stream valley of considerable length. The term was doubtless derived from the French verb couler, signifying to flow. This meaning of "coulee" should not be confused with the geologic meaning of the word, which signifies a solidified stream or sheet of lava.

${ }^{3}$ During the later half of the Cretaceous period the sea covered what is now the region of the Great Plains and the Rocky Mountains as far west as the Wasatch Range in Utah and extended from the Gulf of Mexico to the Arctic Ocean. The incursion of the sea ovor this area was due to the relative sinking of the land. As the land sank the waters advanced, and the waves and currents washed and sorted the sediments brought down by the streams. The coarser sand and gravel were left near the shore, but the finer silt was widely distributed over the sea bottom. As the sea gradually deepened and the shore line advanced the silt covered up the sand; the sand was cemented together as sandstone and the silt was compacted into shale. Varying conditions caused more or less commingling and interbedding of sand and silt, so that numerous beds of sandstone and of sandy shale are now encountered in drilling into the ancient deposits. The long duration of the period in which these beds were laid down is indicated by the great thickness of fine sediment which then accumulated. 
West of Valley City the surface is more or less irregular and hummocky, but no definite moraine has been recognized along the line of the railway. In this part of North Dakota many of the glacial features are not clear and distinct. It is supposed that this is due to the fact that the older ice sheets had left pronounced features that were only slightly modified by the Wisconsin glacier, and the result to-day is that one system of moraines is superimposed on others having different patterns, the features being therefore very much confused.

In the vicinity of Sanborn there are a number of lakes which can be seen from the train, but they are not so attractive as the

\section{Sanborn.}

Elevation 1,468 feet. Population 390. St. Paul 320 miles. lakes of Minnesota, for they are shallow and highly charged with alkali, which in seasons of drought is deposited around their margins as a white powder. This powder is composed largely of such substances as baking soda, washing soda, and other materials having similar properties. The water of these lakes is unsuitable for drinking but is not too strongly alkaline to be used for watering stock. The lakes are generally long and narrow, occupying depressions that resemble stream valleys, but the mode of formation of these depressions has not been determined. At Sanborn a branch line turns to the right, leading northward to Cooperstown and McHenry.

The Waconia moraine, crossed by the Northern

\section{Eckelson.}

Elevation 1,487 feet. Population 327.* St. Paul 326 miles. Pacific Railway west of Eckelson (see p. 4i), constitutes the divide between the Hudson Bay and Mississippi River drainage basins. ${ }^{1}$
1 This divide illustrates the poorly drained character of the glaciated prairies and the delicate balance between the drainage systems. Although Sheyenne and James rivers, the two principal streams of this region, flow in nearly parallel courses for 180 miles, and the relief of the land between them is generally not more than 20 feet, yet the Sheyenne ultimately discharges into Hudson Bay and the James into the Gulf of Mexico. These rivers are very small in proportion to the valleys in which they flow, there being barely sufficient water to maintain them as running streams during the summer season.

The drainage area of the Sheyenne embraces approximately 10,000 square miles, yet the volume of water it discharges into Red River is estimated to be less than that which flows through Valley City, nearly 150 miles upstream. The loss is due to evaporation and absorption as the stream meanders sluggishly over the broad, flat bottom of its valley.
Several broad and deep coulees enter the valley of the Sheyenne from the west, but they are occupied only by intermittent streams, insignificant in size even in times of heavy rain; and the only land that is really drained is that comprised in short, deep gorges which broaden out rapidly toward the Sheyenne as they deploy upon its flood plain.

The drainage basin of James River is much larger than that of the Sheyenne, but a gaging station established by the United States Geological Survey on the James a few miles south of the railway was abandoned because there was not, for a part of the year, sufficient current to turn a water meter.

In periods of heavy rains and melting snows a system of ancient channels is occupied by Maple River and its tributaries; but although these constitute the drainage system for an area of more than 1,000 square miles, ordinarily the run-off is insufficient to maintain a permanent stream. 
Between the Waconia moraine and Spiritwood there are no marked features. From Spiritwood westward for a distance of

Spiritwood.

Elevation 1,500 feet. Population 264.* St. Paul 333 miles. 48 miles no distinctly morainic ridges are visible from the train, but it is believed that the various ridges constituting the Antelope moraine are present in this region, for they have been identified in the country north and south of the railway.

Jamestown is a district terminal, and here a branch turns to the right to Pingree and Devils Lake, and another to the left down the valley of James River to La Moure and Oakes. The

Jamestown.

Elevation 1,429 feet. Population 4,358. St. Paul 344 miles. country is so thoroughly covered with glacial drift that the underlying rocks are not visible along the railway, but deep drilling for water showed that in general on the upland the drift is merely sufficient to conceal the rocks below, and in some of the larger stream valleys it is more than 100 feet deep. This indicates that the valleys of such streams as James River were in existence before the glacial epoch, that during the occupation of this region by the ice they were deeply filled with glacial material, and that since then the streams have succeeded only in partly clearing them of this material.

A deep well at the North Dakota Insane Hospital, in the southern part of Jamestown, passed through 118 feet of glacial drift, 1,330 feet of Cretaceous shale, and about 200 feet of sandstone that is supposed to be the Dakota sandstone, at the base of the Upper Cretaceous. The top of this sandstone is about at sea level, and rises eastward at the rate of about $8 \frac{1}{2}$ feet to the mile.

- The chief occupation in the country around Jamestown is agriculture, the crops being wheat, oats, flax, barley, and vegetables.

West of Jamestown the railway follows the valley of Pipestem Creek as far as milepost $94 .^{1}$ At this point the main valley followed by the branch road leading to Pingree and Devils Lake comes in from the north, but the main railway line keeps directly ahead up a small ravine and reaches the upland near Berner, about 2 miles farther on. In this ravine there are many cuts, which afford excellent opportunities to study the composition of the drift or till, beneath which in some of the cuts a few feet of Cretaceous shale may be seen. In this vicinity the railway is supposed to cross parts of the Antelope moraine, but nothing resembling a definite ridge is in sight.

1 The mileposts about Jamestown are confusing, as the last one to be seen as the train enters the yards, nearly a mile east of the depot, is 99 , and the one mentioned above, where the branch leaves the main line and turns up Pipestem Creek, is 94.
Evidently about 7 miles has been dropped out of the count, but the figures given for each town in the side notes in this bulletin represent the distances from St. Paul that are given in the Northern Pacific Railway folder for 1915 . 


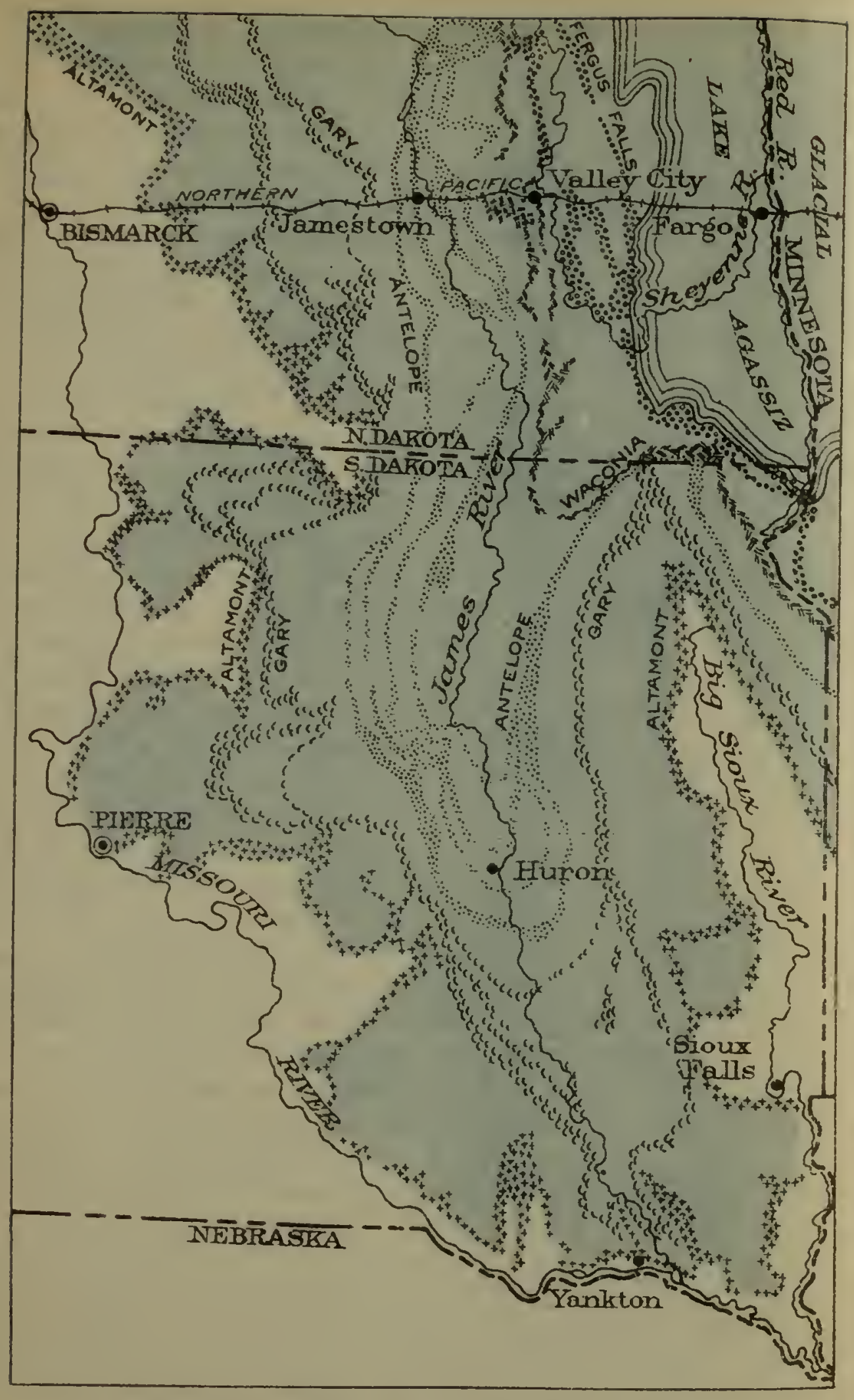

MORAINES FORMED BY THE ICE SHEET THAT CROSSED NORTH DAKOTA IN WISCONSIN TIME





A few miles west of Eldridge (see sheet 6, p. 46) is the easter'n front of a low plateau known as the Coteau du Missouri, ${ }^{1}$ which is mentioned in all the accounts of early explorations in this part

Eldridge.

Elevation 1,563 feet. Population 161.* St. Paul 351 miles. of the country. Doubtless in passing across the country on foot or with a wagon train the Coteau loomed up as a formidable obstacle, but the railway traveler of to-day, unless his attention is particularly directed to it, would probably cross it without realizing that it is a prominent topographic feature.

At milepost 103 the train begins the ascent of the east front of the Coteau, and it reaches the summit just east of Windsor. A comparison of altitudes shows that this summit is almost ex-

\section{Windsor.}

Elevation 1,864 feet. Population 112.* St. Paul 360 miles. actly 300 feet above Eldridge and 435 feet above Jamestown. In a mountainous region a ridge 300 feet high is hardly worth considering, but in eastern North Dakota a plateau of this height is of the first magnitude. The commanding position of the Coteau can better be appreciated by a view eastward from milepost 108, at the east end of the deep summit cut. This view commands a wide expanse of undulating plain, which is backed in the distance by the low swell of Alta Ridge, east of Valley City.

As shown on the sketch map on sheet 5 (p. 44), a small moraine marks the face of the Coteau north of the railroad. It is probable that this is represented by the deep till in the summit cut east of Windsor, but the features visible from the train are not strikingly morainic in character.

The glacial features along the line of the railway are not well marked, but from Cleveland nearly to Medina there are many

\section{Cleveland.}

Elevation 1,874 feet. St. Paul 364 miles.

\section{Medina.}

Elevation 1,816 feet. Population 343 . St. Paul 373 miles. indications, in the form of hummocks and undrained basins, of the morainic character of the topography. Beyond this belt the country is gently rolling. The scarcity of ranch houses is an indication that this is what was formerly called the "short-grass country," but now, in the days of successful dry farming, it has achieved a very different reputation.

Near Crystal Springs the aspect of the country appears to be distinctly morainic in character, but no definite ridge

${ }^{1}$ Coteau is a French term signifying a small hill or hillock. In the northern part of the United States it was generally applied by the early French travelers to a range of hills or to the escarpment form- ing the edge of a plateau. Such an escarpment is usually dissected, so that at a distance it resembles a range of hills. The Coteau des Prairies and Coteau du Missouri are escarpments of this character. 
can be seen from the train. The tracks cross the Gary moraine (see sketch map on sheet 5, p. 44) a short distance west

Crystal Springs.

Elevation 1,802 feet.

Population 216**

St. Paul 382 miks.

of this town, but as the railway follows an old outlet channel, the moraine, as seen from the train, does not appear to be particularly prominent. $\mathrm{A}$ mile or so to the left (south) of the track the moraine is strongly developed, consisting of a ridge at least 125 feet higher than the plain on the west. The gravel showing in big pits near Ladoga is outwash material from the front of the ice when it built the moraine.

Beyond Crystal Springs the country is drift covered but generally flat. This topography continues to Tappen, a flourTappen. ishing village in a belt of good farming land. SeemElevation 1,789 feet. ingly the glacier in passing over this country had Population 117.* St. Paul 389 miles.

little effect except to smooth off and fill up most of the irregularities in the old topography.

In the vicinity of Dawson the most pronounced geologic and topographic feature is the Altamont moraine, which was produced by the Wisconsin ice sheet at the time of its maxi-

Dawson.

mum extension. As shown on the sketch map on

Elevation 1,771 feet. St. Paul 394 miles.

sheet 5 (p. 44), there is a great reentrant angle in this moraine almost due east of Bismarck, at about the place where it is crossed by the Northern Pacific Railway. Owing to this reentrant the moraine trends parallel with the track and is visible for several miles. West of Dawson there are heavy deposits of drift which probably belong to this moraine. They are especially prominent in a cut a mile long between mileposts 147 and 148.

The same rolling topography occurs in the vicinity of Steele and as far west as the western margin of the Steele.

Elevation 1,880 feet. Population 500.

St. Paul 402 miles. moraine. Outwash gravel is also abundant about Steele, as is indicated by the hills of gravel and by the pits from which the railway has procured gravel for ballast.

At Driscoll (see sheet 7, p. 54) is the highest land that is crossed by the Northern Pacific Railway east of Missouri River. Near milepost 163 an old drainage channel, including a chain

Driscoll.

Elevation 1,895 feet. Population 372 .*

St. Paul 413 miles. tance. Beyond Driscoll the railway gradually descends to Missouri River, which in the early days was the great highway to the north- 



\section{western part of the United States and which was first thoroughly explored by Lewis and Clark. ${ }^{1}$}

${ }^{1}$ One of the most noteworthy explorations that was successfully carried out in the nineteenth century was that of the headwaters of Missouri and Columbia rivers by Meriwether Lewis and William Clark in the years 1804-1806, and as the Northern Pacific Railway follows in a general way a part of the same route and is the indirect result of their efforts it seems appropriate to give here a brief sketch of the expedition and of the commanders. It is so easy now to cross the continent in comfort and even in luxury that the difficulties and hardships of such a journey in 1804 can not readily be realized.

Meriwether Lewis was born August 18, 1774 , near Charlottesville, Va., of one of the distinguished families of the State. He had been for two years the private secretary of President Jefferson and was serving in that capacity when he was selected by the President as commander of the exploring expedition to the Pacific coast. Upon the completion of his long trip Capt. Lewis returned to Washington, but soon afterward (Mar. 3, 1807) he was appointed governor of Louisiana and departed for St. Louis to assume the duties of that office. These occupied his attention for two years, when he again found it necessary to visit Washington. He first planned the trip by water, but after going as far down the river as Chickasaw Bluffs (Memphis) he changed his mind and started east across the country. On the way he committed suicide or was murdered October 11, 1809, in Lewis County, Tenn.

William Clark was born in Caroline County, Va., August 1, 1770. He had a number of brothers and sisters, of whom George Rogers Clark, an elder brother, achieved distinction as a military commander. When William Clark was 14 years old the family moved to the place then called the Falls of the Ohio, now Louisville, Ky. The town at that time consisted merely of a few cabins clustered around a fortification which had been erected by Clark's elder brother. When the exploring trip to the Pacific coast was undertaken Clark was selected by Lewis as joint head of the party. Soon after his return he was made Indian agent for Louisiana, with headquarters at St. Louis, and on February 27, 1811, he was appointed by President Madison brigadier general of the militia of Louisiana. On July 1, 1813, he was made governor of Missouri, an office which he held until the Territory was admitted to the Union in 1821. In May, 1822, President Monroe appointed him Superintendent of Indian Affairs, and he held that post until his death at St. Louis September 1, 1838. His funeral was the most impressive that had ever been held in that city.

When Thomas Jefferson was inaugurated President of the United States, in 1801, our country did not extend west of Mississippi River, and already much friction had arisen between Spain and the United States regarding the navigation of that stream. Jefferson fully realized that for the complete development of the Mississippi Valley it was necessary that we should control the mouth of the river. Accordingly he began negotiations with Spain for the purchase of New Orleans and the Floridas.

Louisiana was originally a French possession through the discoveries of La Salle. It had been an expensive and troublesome province for France and for this reason it was secretly conveyed to Spain in 1762 . In the year 1800 , however, it was by another secret treaty ceded back to France. It was therefore a surprise to our negotiators to find that it was France and not Spain with which they would have to treat.

At the time negotiations were opened Napoleon was expecting a declaration of war by England and the seizure by her of the mouth of the Mississippi. This threatened his supremacy in America as well as in Europe, and in order to anticipate this move he decided to cede to the United States not only New Orleans and the Floridas but the entire province of Louisiana, which was an empire in extent. Out of it has been formed the States of Arkansas, 
The village of Sterling is situated at the outer border of the Altamont moraine, at the western limit of the great ice sheet that occupied this region in the last stage of the glacial epoch. Sterling.

Elevation 1,834 feet. Population 198**

St. Paul 421 miles. Below it and stretching far to the west is a plain which was formed of clay, sand, and gravel that were accumulated by the ice and swept along to its outer margin. From Sterling may be obtained an extended view of the outwash plain, toward the south, and far beyond the more rugged country bordering Missouri River.

Missouri, Iowa, Nebraska, North Dakota, and South Dakota; nearly all of Louisiana, Oklahoma, Kansas, Wyoming, and Montana, about one-third of Minnesota, and one-third of Colorado. The treaty by which all of this territory was acquired was executed in Paris April 30, 1803. The compensation was $\$ 11,250,000$ and the assumption by the United States of the "French spoliation claims," "estimated to amount to $\$ 3,750,000$. It is an interesting fact that some of these claims are still in process of adjudication.

The extent and boundaries of the province of Louisiana were never definitely stated. In the treaty the territory was described merely as being the same as that ceded by Spain to France by the treaty of San Ildefonso. From this it appears that the territory sold to the United States comprised that part of the drainage basin of the Mississippi which lies west of the river, with the exception of such parts as were then held by Spain. The lack of precise definition was not objected to by the American commissioners, as they probably foresaw that it might prove of service in future negotiations with other powers.

At that time all the territory on the Pacific coast now included in the State of California was claimed by Spain, and the great region later to be embraced in the States of Oregon, Washington, and Idaho was a sort of no man's land. Subsequently, in treating with Great Britain regarding the northern boundary of the United States, this region was claimed by the United States on three grounds: (1) Discovery and occupation, (2) Louisiana purchase, and (3) cession from Spain. At first none of these claims were recognized by Great Britain, and by the treaty of peace in 1818 it was agreed that the country immediately south of the fortyninth parallel and west of the "Stony" (Rocky) Mountains should remain open to both parties. In 1846 the WebsterAshburton treaty with Great Britain fixed the northern boundary of the United States west of the Rocky Mountains at the forty-ninth parallel as far as the Strait of Fuca, and thus Oregon, Washington, and Idaho finally were recognized as belonging to this country.

On the acquisition of Louisiana an expedition was planned by President Jefferson "to explore the Missouri River and such principal streams of it as, by its course and communication with the waters of the Pacific Ocean, whether the Columbia, Oregon [another name for the Columbia], Colorado, or any other river, may offer the most direct and practicable water communication across the continent for the purpose of commerce." After receiving the requisite instructions Capt. Lewis left Washington July 5, 1803, and proceeded to Louisville, where he was joined by Capt. Clark. They arrived at St. Louis in December, but found that the Spanish commandant of the province, not having received an official account of the transfer, was obliged by the general policy of his Government to prevent strangers from passing through Spanish territory. The party therefore camped on the east side of the Mississippi, where they passed the winter in making the necessary preparations for setting out early in the spring, but they did not leave until after the cession of Louisiana had been formally announced.

The party when it left St. Louis comprised, besides the two officers, nine young men from Kentucky, fourteen soldiers of 
The outwash plain with its silty soil is well adapted to the raising of flax, wheat, oats, and barley and supports a thriving farming community, the center of which is McKenzie, the juncMcKenzie.

Elevation 1,725 feet. Population 191.* St. Paul 427 miles. tion point of a branch line of railway running south to Linton, 45 miles distant. West of McKenzie the railway follows down Apple Creek to Missouri River. The width of the Apple Creek valley, which is much greater than that of even larger streams in the vicinity, indicates clearly that at some time in the past this stream must have been

the United States Army who had volunteered their services, two French water men, an interpreter and hunter, a black servant belonging to Capt. Clark, and a corporal, six soldiers, and nine water men who were to accompany the party as far as the Mandan villages.

The party finally embarked on the momentous voyage of discovery up Missouri River on May 14, 1804. The letter from President Jefferson instructed them to gather information on a great variety of subjects, including "the soil and face of the country, its growth and vegetable productions; the animals of the country, and especially those not known in the United States; the mineral productions of every kind, but more particularly metals, limestone, pit coal, saltpeter, salines, and mineral waters * * *; volcanic appearances; and climate." They were particularly advised to cultivate friendly relations with the Indians and to make exhaustive notes regarding their habits and customs, their family and tribal relations, and the extent and limits of their territorial possessions. They carried out these instructions so fully that the summer was passed and the autumn well advanced before they reached the North Dakota region. By October 26 the weather had become so severe that they went into winter quarters 7 or 8 miles below the mouth of Knife River and 50 miles or so above the present town of Bismarck. Here they built a stockade which they called Fort Mandan, after the tribe of Indians inhabiting this part of the country.

They spent the winter in procuring supplies for the camp, in friendly intercourse with the Indians, and in visiting the scattered French and English traders who were dealing with the Indians on both sides of the Canadian line. On April 7, 1805, the permanent party, which had been increased by the interpreter, Toussaint Charboneau, and his Indian wife, Sacajawea (sak-a-ja-we'a, meaning bird woman), again set out on their journey up the great river. They were soon beyond the range of the fur trader and they saw no white man until they returned to this region the following year. All went well until they came to the Great Falls of the Missouri, which the Indians had described to them. After a laborious portage around the falls they proceeded onward, searching for a path through the "Shining Mountains," which lay in rugged masses before them.

Their instructions were to explore the best route from the Missouri to the Columbia, but, although they had fairly reliable information from the Indians regarding the headwaters of the Missouri, they were completely at sea regarding the source of the Columbia. For this reason they desired very much to find Indian guides to pilot them across the mountains. Sacajawea, a member of the Snake tribe, who had been captured by the Mandans when she was a young girl and carried off to the Indian towns in North Dakota, hoped that she might see some of her people inhabiting the mountain region at the head of the Missouri and procure from them the necessary information and assistance.

Above Great Falls the river swings far to the west, approaching the mountains, and the leaders looked anxiously for signs of Indians, but none could be found. To make the matter worse, the river here 
much larger than it is at the present time. 'The increased volume of water in Apple Creek was due to the fact that it received a large part of the drainage of the ice sheet that piled up the Altamont moraine. Much of the clay, sand, and gravel washed out from the ice was carried down to Missouri River and swept southward by its mighty current, but a large amount was dropped along Apple Creek, filling the valley to a considerable depth. Since the disappearance of the ice the stream has cut a channel in this material 70 or 80 feet deep. 'The uplands on both sides of the valley of Apple Creek have only a thin veneer of glacial drift. (See footnote on p. 54.)

The great amount of cutting done by Apple Creek when it was flooded by water from the melting ice is shown by the width of its flood plain where the valley joins that of Missouri River. At the State penitentiary 2 miles east of Bismarck the valley of Apple Creek has a

changes its course and they were forced to travel away from the mountains for a long distance; but on coming to the three forks of the Missouri Sacajawea remembered the country and saw the spot where she had been captured many years before. The expedition proceeded up Jefferson River to its head and crossed the Continental Divide (at Lemhi Pass) into Idaho. Here they met the Snake Indians, Sacajawea even finding her brother and sister, but after repeated efforts they decided that it was impossible to make their way down Salmon River to the Columbia, so they turned northward, crossing the range again, and followed down the Bitterroot Valley until on September 10 they came within 8 miles of the place where Missoula, Mont., is now situated. Here they turned to the left up what is now known as the Lolo trail and crossed the Cour d'Alene Mountains, arriving at the mouth of Snake River October 16. From this point they rapidly drifted down the Columbia to the Pacific Ocean and went into winter quarters December 7 in a stockade which they named Fort Clatsop, near the site of Astoria, Oreg. They remained here, without seeing any vessel from which they could obtain supplies, until March 23, 1806, when they left Fort Clatsop on their eastward journэy.

The party returned over practically the same route to the Bitterroot Valley, where it was divided, Capt. Lewis making his way by Missoula and up Blackfoot River, along the route followed $\mathrm{ky}$ the Indians in going to the plains to hunt buffalo, and Capt. Clark going back to the head of Jefferson River to recover their canoes, which had been cached at that place. Capt. Lewis crossed the Continental Divide at Lewis and Clark Pass and then made an attempt to explore the pass at the head of Marias River (now utilized by the Great Northern Railway), but trouble with the Indians prevented him from reaching the mountains, so he embarked on the Missouri and floated down to the mouth of the Yellowstone, where the two parties were to meet again on their homeward journey.

Capt. Clark crossed through the Bighole country and, after getting the boats, floated down Jefferson River to Three Forks, where his party again divided, some going on down Missouri River to join Lewis, while Capt. Clark and a few others, including the faithful Sacajawea as guide, started across the country to Yellowstone River. They crossed Bozeman Pass July 15, 1806, and reached Missouri River at Livingston the same day. They passed rapidly down the stream, reaching the mouth of Tongue River (Miles City) on July 29 and the mouth of Yellowstone River August 3. They were slightly ahead of Capt. Lewis and the party was not united until August 12 , when they all came together at the mouth of Little Knife River, N. Dak. The rest of the journey was uneventful and they reached St. Louis Septemter $23,1806$. 
width of 4 miles, whereas the width of the Missouri Valley rarely exceeds 3 miles. On this flood plain, known as the "second bottom," is Fort Lincoln, to the left (south). This is the only military post now maintained near the Canadian border between Fort Snelling, at St. Paul, and Fort Assinniboine, at I Mont. Opposite the penitentiary the Northern Pacific crosses aranch of the Soo Line which extends up the river as far as Washburn.

Bismarck, the capital of the State, was named in honor of the great German chancellor. This town was the western Bismarck. terminus of the Northern Pacific Railway from Elevation 1,692 feet. 1873, when all construction work was stopped by Population 5,443.

St. Paul 446 miles. the financial panic, to 1878 , and was originally called Edwinton, for Edwin F. Johnson, the first chief engineer of the road.

Those who are in the habit of reading the daily weather reports may have noted that Bismarck has about as great a range of temperature throughout the year as any other place where observations are recorded. In summer the thermometer occasionally registers $100^{\circ}$ or more, and in winter it is frequently as low as $40^{\circ}$. below zero. The precipitation is only 18 or 19 inches a year, compared with 28 inches at Minneapolis. This difference in the amount of moisture received is largely the cause of the difference in the appearance of the two regions.

West of the station at Bismarck the railway skirts the eastern bluffs of the river for a distance of 2 miles upstream and then crosses on a steel bridge to the west side. ${ }^{1}$

1 At present Missouri River has little effect on the commercial and industrial life of the northwestern part of the United States, but before the construction of the transcontinental railways it was a most important factor, first in the exploration of that part of the country and second in its commercial development.

The country about Bismarck and Mandan was formerly inhabited by the Mandan Indians. The surviving remnant of this trike occupies the Fort Berthold Reservation, some 60 or 70 miles farther up the river, but almost every day groups of these Indians can be seen alout the station at Mandan or on the local trains of the river branch.

The earliest recorded visit of a white man to these Indians was that of Verandrye in 1738-1742, when he attempted to cross the continent to the Pacific coast. David Thompson, of the Northwest Fur
Co., was here in 1797, and Lewis and Clark wintered about 50 miles north of Bismarck in 1804-5. After that date many explorers and traders came this way, gradually extending their operations westward until they finally overran the whole region, even including the rougher parts of the Rocky Mountains. Supplies were sent to the fur-trading stations by boat up the Missouri from St. Louis, and the furs obtained from the Indians found their way to the outside world by the same route. The river at that time was a silt-laden shifting stream, just as it is to-day, and great difficulty was experienced in getting supplies to its upper waters. The river traffic was greatly stimulated by discoveries of gold in Montana in 1863, and light-draft steamboats were employed in the trade. This traffic continued to increase until the completion of the Northern Pacific Railway, when 
The town of Mandan, named for the tribe of Indians that formerly occupied this part of the country, is on the west side of the Missouri. It is essentially a railway town, being a division termiMandan.

Elevation 1,667 feet. Population 3,873. St. Paul 451 miles.

nal. In coming from the east the traveler has had very few opper the rocks underlying the glacial drift, west we wandan the drift is thin or lacking and the bedded rocks are much more conspicuous than they are east of that place. In places about Mandan they are exposed in badlands, as shown in Plate IV, $A$.

A deep well that was drilled at Mandan a number of years ago with the hope of obtaining water for railway and town use penetrated sandstone and shale much like the surface rocks to a depth of 470 feet and then nothing but shale like that seen at Jamestown to a depth of 2,000 feet. The drill probably went nearly to the Dakota sandstone, which furnishes artesian water farther east in North and South Dakota, but as it did not reach that rock the exact depth of the Dakota is not known.

In 1876, when the railway extended westward only as far as Bismarck, this town was a mere frontier settlement with a wide stretch of Indian country to the west. On the west side of the river was Fort Abraham Lincoln, one of the important military posts of the time. Although the days of Indian warfare in this vicinity had passed, it was the starting point for many military expeditions into the Indian country. An expedition of this kind which left the fort in 1876 was the most eventful in the history of the border warfare of the region, as it resulted in the Battle of the Little Bighorn and the slaughter of Gen. Custer and his immediate command. The Northern Pacific Railway has been built along or closely parallel with the route followed by the troops. (See p. 71.) At Mandan the railway changes from Central to Mountain time, and the westbound traveler should set his watch back one hour.

West of Mandan the railway follows the valley of Heart River, and for the first time in North Dakota the westbound traveler can see the hard rocks well exposed. These consist of shale and sandstone (Lance

the slow and unsatisfactory method of boat transportation was abandoned, so that to-day vessels are seldom seen upon the muddy waters of the river.

The Missouri is one of the great drainage channels of the United States. Its total length is about 2,400 miles, and that part above the crossing of the Northern Pacific has a langth of about 1,160 miles. The total area drained by this river is 527,155 square miles, a territory as great as that embraced in the States of
New Jersey, Pennsylvania, Ohio, Delaware, Maryland, Virginia, West Virginia, Kentucky, North Carolina, Tennessee, South Carolina, Georgia, Alabama, and Mississippi.

Although Missouri River may never again be utilized as a means of communication and transportation, it is destined to play a most important part in the better development of its drainage basin by furnishing water for irrigation and for the development of power. 


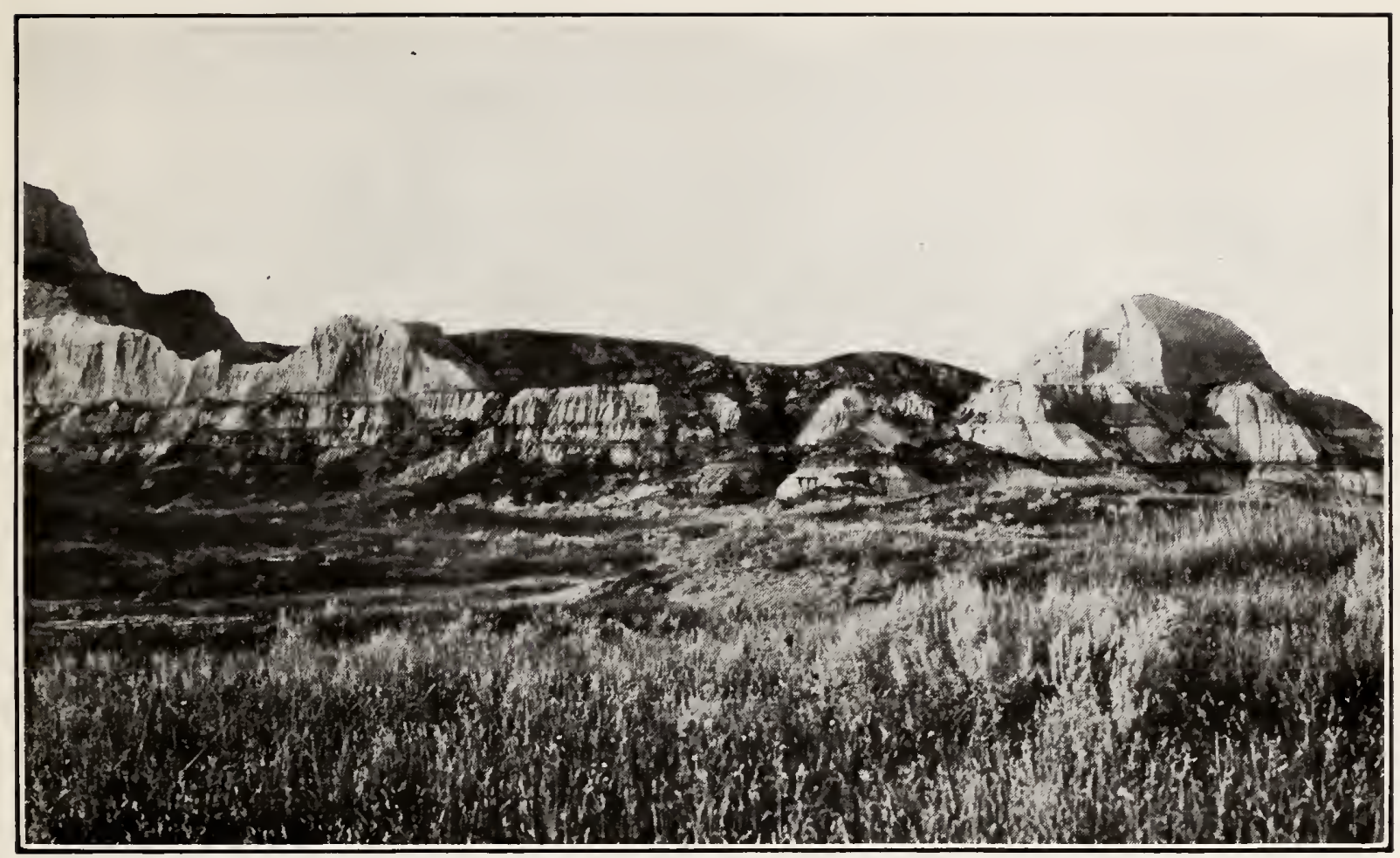

A. BADLANDS IN THE VICINITY OF MANDAN, N. DAK.

These are not so rugged or picturesque as those to be seen farther west, where the precipitation is less.

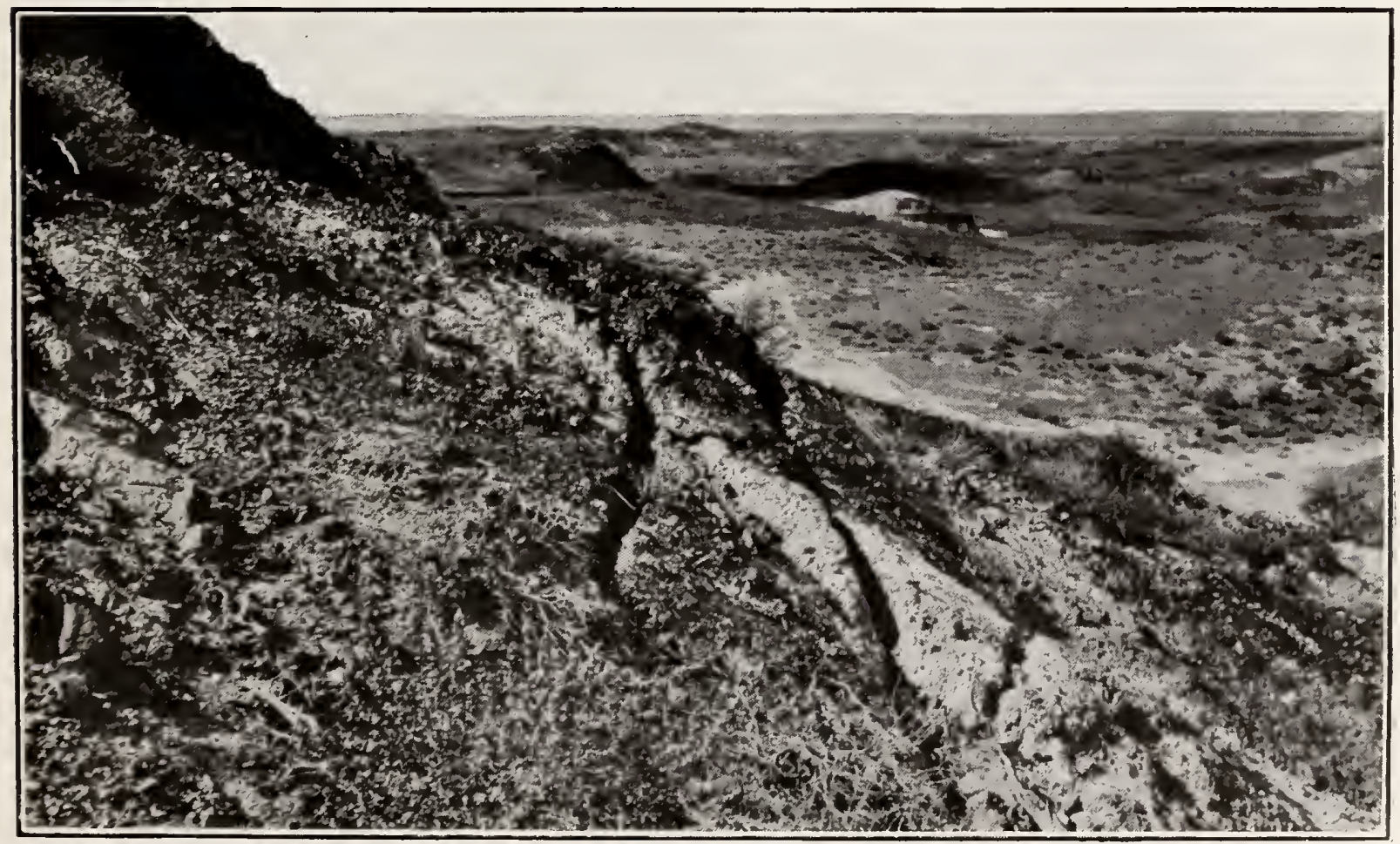

B. CRACKS PRODUCED BY THE BURNING OF A BED OF LIGNITE:

Where a bed of lignite many feet thick burns, the sandstone or shale overlying it breaks down, forming large cracks through which steam and smoke issue as long as the lignite is on fire. 




A.

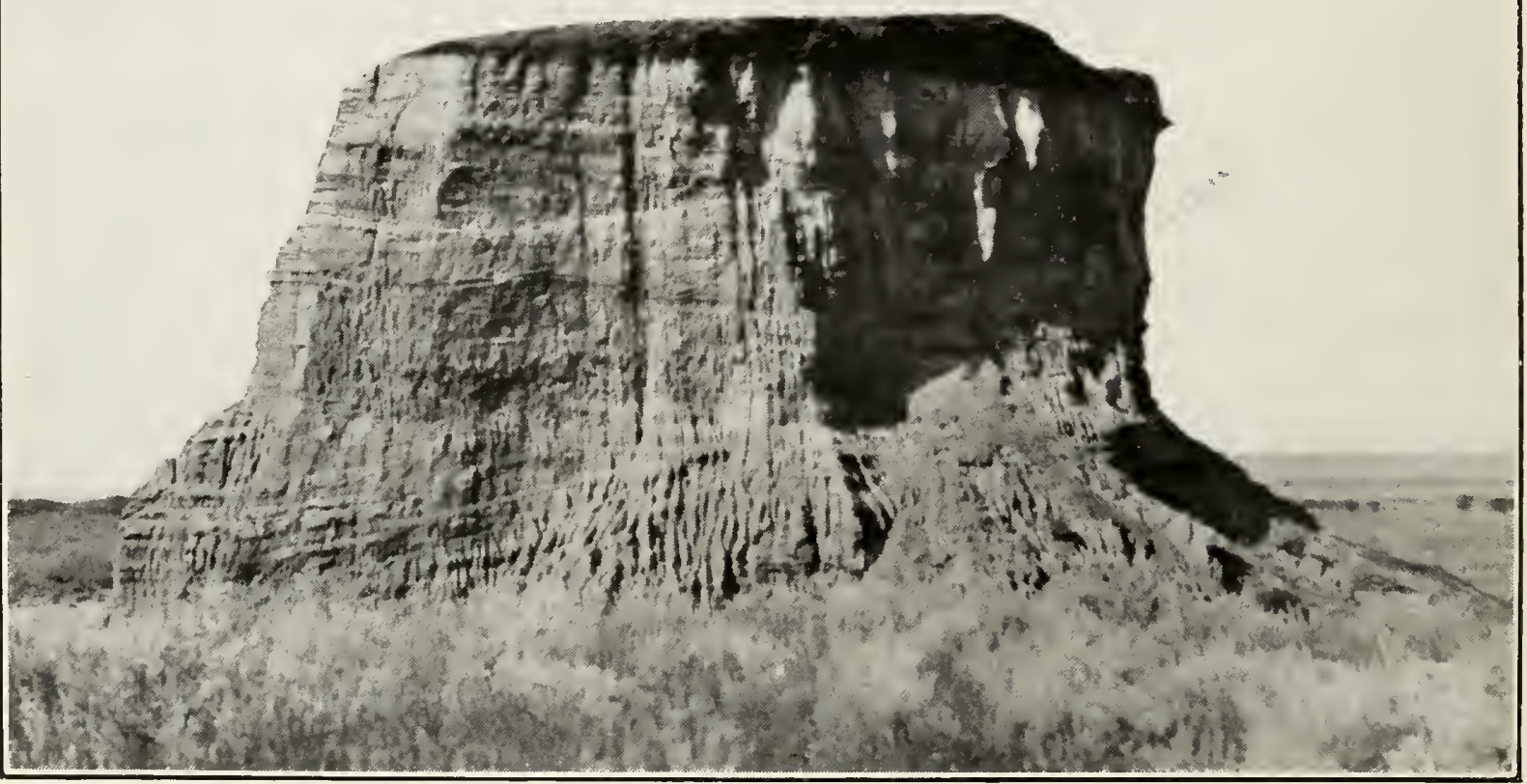

$P$.

EROSION FORMS OF NORTH DAKOTA.

As soon as the turi is rernoved from the sides of the ridges and hills the slopes are cut rapidly by the rain. Each little trickle of water cuts a hole vertically through the sand or clay, producing a surface which, when seen from above, resembles a gigantic sponge. Its general appearance is shown in the upper view. When erosion has reached a more advanced stage, the hill may be reduced to an isolated butte, as shown in the lower view, and the sides are covered with the most delicate tracery. 
formation), partly of marine origin, and represent the bottom of the sea that through later Cretaceous and part of Tertiary time covered the region. 1

The railway follows Heart River for some distance and then turns to the right and climbs to the upland along Sweetbriar Creek. Here large bowlders of granite and other similar rocks may

\section{Judson.}

Elevation 1,971 feet. St. Paul 473 miles. be seen on both sides of the track. These are particularly numerous and very large, some as much as 8 feet in diameter, in the vicinity of Judson, but scattered bowlders can be seen from the car window beyond New Salem. Rocks of this kind are not known to crop out in the State, so it is supposed that the bowlders must have been brought here by ice, but as

1 The rocks exposed along Missouri River from the vicinity of old Fort Pierre in South Dakota to and beyond the crossing of the Northern Pacific Railway at Bismarck dip slightly to the north or northwest and are encountered in going up the stream in ascending order. First is the Pierre shale, which consists of a great mass of fine dark shale that carries marine shells wherever it has been found from the Canadian line to New Mexico. It was doubtless laid down when the entire Rocky Mountain and Great Plains regions were sunk below the level of the ocean.

This formation is overlain by a coarse, generally clean white or brownish sandstone, called Fox Hills, which was evidently at one time the sandy shore that followed the retreat of the Pierre sea. Sandstone as a rule is not good material for the preservation of fossils, but here and there the Fox Hills sandstone contains marine shells and almost everywhere the casts of sea weeds, which now resemble fossil corncobs. Until very recently this has been regarded as the last formation in this region that was laid down in sea water.

The Fox Hills sandstone is followed by the Lance formation, which consists of sandstone, shale, and coal beds. Few shells occur in the Lance, but those that have been found in the larger part of the area are fresh-water forms. The presence of many coal beds (composed of vegetation that once grew on the land and was buried in swamps) and of fossil leaves and trunks of trees in the sandstone and shale shows clearly that the Iance formation accumulated above sea level as material either brought down by streams and spread out over the even surface of the land or deposited in lakes. This formation covers much of the mountain and plains country north of Colorado, and in most of this broad area it contains nothing but fresh-water material. Recently, however, marine and brackish-water shells have been found in the upper part of the Lance in south-central North Dakota and also along Little Missouri River in the southwest corner of the State, which indicate that after the recession of the sea to the east at the close of Fox Hills time it reappeared and reached as far west as the Montana line. Then at the close of Lance time the sea again disappeared from this region, never to return, as all succeeding formations are of fresh-water origin.

For many years the age of the Lance formation has been in dispute. The fossil shells and the great dinosaurs (see p. 73) indicate that the formation is Cretaceous in age, but the fossil plants are Tertiary in their relations, almost identical with those of the overlying Fort Union formation. Although the question is not finally settled, it seems probable that the Cannonball member of the Lance formation is Tertiary and that the Cretaceous fauna which occurs in it is merely a surviving remnant of an old Cretaceous fauna which formerly lived in the open sea but which as this sea became more and more restricted and eventually inclosed by land preserved its old form even into Tertiary time. 
little or no other drift accompanies them, they are supposed to represent an earlier ice invasion than that which brought the drift east of Missouri River-an invasion so long ago that most of the clay in the drift has been washed away, leaving only the coarser material. ${ }^{1}$

About half a mile east of the station at New Salem (see sheet 8, p. 60) the lignite mine of the Dakota Products Co. has been in operation for a number of years. The bed of lignite mined

New Salem.

Elevation 2,188 feet. Population 621.

St. Paul 479 miles. is 5 feet thick and lies about 30 feet below the surface. ${ }^{2}$ West of New Salem, which is situated on the surface of the upland plain, the railway goes down a small ravine in which scattered granite bowlders can be seen from the car window for a distance of 5 miles, or as far as milepost 33. Beyond this point no bowlders can be seen, but careful examination of the surrounding upland has shown that they are present as far to the southwest as Almont.

${ }^{1}$ West of the Altamont moraine, which marks the greatest extension of the glacial lobe that occupied the Red River valley in Wisconsin time, there is only a thin veneer of drift on the upland and in some of the valleys. This outer drift is not bordered by any well-marked moraine, but here and there indications of such a feature occur along its outer margin on the west side of Missouri River. In the vicinity of the Northern Pacific Railway the moraine is characterized by a low bowldery ridge which trends nearly south from Judson. Outside of this moraine there is a marginal fringe of bowlders which extend as far west as Almont.

The general thinness of the drift west of the Altamont moraine indicates that the material which was brought by the ice has almost all been washed away, except the large bowlders; and this means that a much longer time has elapsed since it was deposited thian there has since the material east of the Altamont moraine was laid down. Some geologists have argued that this outer drift represents a stage of glaciation very much older than the Wisconsin and have assigned it provisionally to the Kansan (one of the earliest stages known). Others have maintained that the granite bowlders which can be seen from the Northern Pacific Railway are too fresh and unweathered to have been dropped here during the Kansan stage, many thousand years ago; but the unweathered condition of the granite is due to the dryness of the climate and therefore is not a reliable criterion as to the age of the drift.

From all the facts at hand it is evident that the glacier which crossed Missouri River was older and thinner than the one which occupied the Red River valley, but the difference in age is problematic.

2 The lignite bed is reached by a slope, and from the bottom of the slope the workings extend north about 2,100 feet. The lignite bed is almost horizontal. It ranges in thickness from $4 \frac{1}{2}$ to 6 feet and is underlain by a bed of gray clay. Most of the lignite produced at this mine is either hauled by wagon to the surrounding country and used by the farmers or shipped by rail to the neighboring towns. North Dakota lignite represents one of the early stages in the transformation of vegetable matter into coal. The products of the various stages now recognized are (1) wood, (2) peat, (3) lignite, (4) subbituminous coal, (5) bituminous coal, (6) semibituminous coal, (7) semianthracite, and (8) anthracite. Much of the lignite is woody, and frequently logs and stumps are found in the mines. It is generally brown, and the woody parts will bend without breaking. The lignite of this State, as it comes from the mine, carries about 40 per cent of water. It will readily dry down to 8 or 10 per cent if stored in a dry place with good ventilation, but in so doing it shrinks and falls to picces. This falling to pieces is generally 

Some 10 years ago several lignite mines were in operation at Sims, but now all but one of these are closed and abandoned. The bed of lignite mined here is 7 or 8 feet thick, and in drilling Sims.

Elevation 1,982 feet. nesses of about 5 feet each were found. According Population 86. St. Paul 487 miles.

to the $\log$ of this well there is 29 feet of lignite below the surface at Sims in beds thick enough to work, and the lowest is at a depth of 710 feet.

Below Sims the railway follows the small valley of Hailstorm Creek and affords no general view of the country. Just east of Almont the valley of Hailstorm Creek joins that of Muddy Creek, Almont.

Elevation 1,933 feet. St. Paul 492 miles. which the railway, making a sharp turn to the right, ascends practically to its head. This valley shows excellent examples of stream meanders, the creek making great loops whose ends in places nearly connect.

called slacking (from its likeness to the slacking of lime, though lime slacks by taking up moisture and lignite by parting with it), and the process takes place rapidly where it is exposed to alternate moisture and dryness.

Manifestly a fuel containing 40 per cent of water can not be shipped any great distance, as the purchaser can not afford to pay transportation charges on so much water. The lignite is also difficult to handle on account of the slacking or breaking up, and when stored it is likely to ignite spontaneously by its rapid combination with the oxygen of the atmosphere or of water. Altogether it is far from an ideal fuel, though very useful for domestic purposes in this treeless country. Although lignite is a poor fuel for raising steam, it is well adapted to making producer gas that can be used economically in a gas engine for the production of power, and probably in the future it will be utilized largely in this way. The chief difficulty at present is that there is only a small demand in this thinly settled country for power, and hence there would be little market for the product, but it is possible that with the growing use of long-distance transmission lines the lignite could be utilized for the production of electric power at the mine and the current carried to distant towns and cities or even to ranches for utilization. Lignite has been found to be an excellent fuel for burning brick and is now used extensively at Dickinson and other towns in the State for that purpose.

Lignite occurs most abundantly in the Fort Union formation (the lowest formation in the Eocene series of the Tertiary system), which underlies almost all the western part of North Dakota. It is estimated that the State contains the enormous amount of $697,900,000,000$ short tons of lignite in beds over 3 feet thick and within 1,000 feet of the surface, and it seems probable that there is workable lignite within this limit under every section of the land in the western part of the State. It is difficult to form an idea of a mass containing even 1,000,000 tons, and hence the figures given above are practically impossible of comprehension, but if the amount is put in the form of a cube a better conception of its magnitude may be obtained. The lignite of the State, if gathered into one mass in the compact form in which it lies in the ground, would make a cube 5 miles long, 5 miles broad, and 5 miles high. Such a cube would cover nearly a township of land and would be almost as high as the highest mountain on the globe.

The lignite, although of poor quality and at present used only in a small way, constitutes a vast fuel resource which will in time become of great value, not only to the individual citizens of the State but to the corporations that are seeking power for use in manufacturing or in transportation. 
About 11 miles from Almont, at milepost 51, there are on the right (north) about a mile distant many knobs and spurs having a brightred color. When examined closely the color is seen to run in more or less regular horizontal bands, like the rock, but it is not continuous, and in places it affects the whole hillside. This color is due to the burning of beds of lignite, which has baked and reddened the originally dark strata on either side, as clays originally brown or gray in color turn red when burned into brick. ${ }^{1}$

The success of dry farming has led to the settlement of almost all of western North Dakota, and towns have sprung up along the railroads like magic. Glenullen is one of the newer Glenullen.

Elevation 2,090 feet. Population 921.

St. Paul 509 miles. towns, and from its general appearance it is evident that in this region dry farming is a success. Although grassy slopes or fields of grain predominate in this part of the State, the appearance at intervals of bare knobs or buttes indicates that everywhere under the surface are the same lignite-bearing rocks that were seen farther east, those of the Fort Union formation. These rocks, when searched carefully, are found to contain many impressions of fossil leaves which show that the sands and muds, now hardened to rock, were laid down in shallow water near a land surface upon which trees and smaller plants grew in abundance. Where the land was swampy the vegetation was covered as it fell and in time was changed into lignite. In this part of the country the lignite is generally concealed by the grassy slopes,

${ }^{1}$ All through the lignite region and the fields of low-grade coal of the Rocky Mountains and Great Plains the coal beds have burned extensively along their outcrops, the resulting red color giving a touch of brightness to some otherwise dull and monotonous landscapes. In some places the burning has been just sufficient to color the shale and sandstone to a bright red, but in others, where the lignite bed is thicker or where more than one bed has burned, the heat has been so intense that the rocks have been melted into a sort of slag or scoria, good examples of which will be seen farther west. When a thick bed of coal or lignite burns, the overlying material settles, and frequently great cracks are formed, out of which issue smoke and steam from the burning lignite below. An example of such cracking is shown in Plate IV, $B$ (p. 52).

As the lignite retains much of its original woody character it ignites readily when dry, and the fires may have begun in any one of several ways. For instance, they may have been started by prairie fires, by lightning, by camp fires, or even by alternate wetting and drying, which causes very rapid oxidation and a consequent rise in temperature. The last suggestion may appear improbable, but the writer has seen a large pile of low-grade coal take fire after a rain and be entirely consumed. The burning of a dump of waste material is a common experience at many mines, and rarely is the fire started by man. Once started, the burning of a coal bed will continue as long as air is available. Near the outcrop the coal burns readily, but back under cover the amount of air is not sufficient for combustion and the fire dies out. Many coal and lignite beds are burning to-day, and it is possible that one may be seen in the badlands called Pyramid Park, farther west, near Sully Springs, N. Dak. 
but farther west many beds are exposed in the hillsides. The fossil plants of the Fort Union formation indicate very different conditions during the Eocene epoch from those which prevail to-day. A brief sketch of the flora, together with an interpretation of its meaning, is given below by F. H. Knowlton. ${ }^{1}$

The railway gradually ascends the valley of Muddy Creek, and if the traveler is not looking carefully he will cross the divide and enter the valley of Knife River without being aware that he has passed out of the valley in which he has been traveling from Almont. As a matter of fact the two valleys are continuous, and it seems probable that originally the drainage from the vicinity of the summit at Antelope came into Muddy Creek, but that some change has occurred by which the drainage about Hebron has been turned northward into Knife River. The details of this change have not been

${ }^{1}$ As the traveler rides mile after mile over the almost barren plains of Dakota and eastern Montana and sees them shimmering in the heat of midsummer, with only an occasional cottonwood or box elder along the streams or sprawling, stunted junipers on the rocky slopes to relieve the monotony, he finds it difficult indeed to realize that this country once supported a vegetation as luxuriant and varied as that now growing in any of the Southern States. However, it will require only a brief examination of the rocks to convince him of the truth of this statement, as they contain in many places the remains of vast numbers of branches, leaves, fruits, and even a flower here and there. Fossil remains have aptly been called the illustrations in the world's history, of which the pages are the layers of rock forming the outer part of the crust of the earth. - It is the purpose now to look at a few of these illustrations and by this means restore in imagination the ancient vegetation.

Fossil plants are very abundant in the Fort Union formation and are found in the sandstone, in the harder concretions or lenses, and in the clay between the sandstone beds. Most of them, especially those in clay, are preserved with remarkable fidelity. About 300 species have been described, and it is probable that the total number may be found to reach 500 or more species.
Beginning with the plants of the most simple structure, we may first consider the ferns. One of the most abundant and widespread forms, having been found at hundreds of localities, is the beautiful sensitive fern Onoclea. This can not be distinguished from the living species, which now grows so widely over eastern North America. There is also a chain fern (Woodwardia) very closely resembling a living species, and numbers of others that are more or less closely related to forms now growing in the Eastern States.

The conifers, though not numerous in species, were very abundant and were of the types that must have been of rather imposing appearance. The most abundant form is a redwood (Sequoia) that is very closely related to the redwood which is now confined to the coast regions of California. There was also another Sequoia nearly related to the big trees of California, but it was not so abundant as the other form. With these was a cypress (Taxodium) that must have been much more beautiful than the common cypress of our southern swamps. There was also a cedar(Thuya), with delicate juniper-like foliage, that must have been very numerous, as its fossil remains are widespread in the Fort Union formation. In strange contrast to these conifers is what appears to have been the immediate ancestor of the celebrated ginkgo, or maiden-hair tree 
worked out, but it was doubtless caused by glaciers which crossed Missouri River and extended to the southwest as far as this valley, damming the streams and compelling them to find new outlets.

Hebron, one of the new towns of western North Dakota, is the center of a prosperous agricultural district and is noted for the manufacture of fire and pressed brick, the clay for

\section{Hebron.}

Elevation 2,180 feet. Population 597.

St. Paul 522 miles.

which is derived from the Fort Union formation. The bed of clay utilized is at least 50 feet thick. Beyond Hebron the railway follows the broad, open valley of Knife River to its head, where there is a steep climb to the summit of the dividing ridge between that stream and Heart River on the southwest. The highest point is reached a short distance beyond Antelope, where a good view can be obtained of the upland surface of this part of North Dakota. The surface is gently undulating, but here and there on the principal divides there is a high knob that has not been reduced by erosion to the general level. The sides of these knobs are generally bare, and they have been sculptured by the rain, the frost, and the wind into most beautiful and intricate forms. (See Pl. V, p. 53.)

of China and Japan. The ginkgo has had in many ways a more wonderful geologic history than any other tree now living, as it has come down to us practically un-

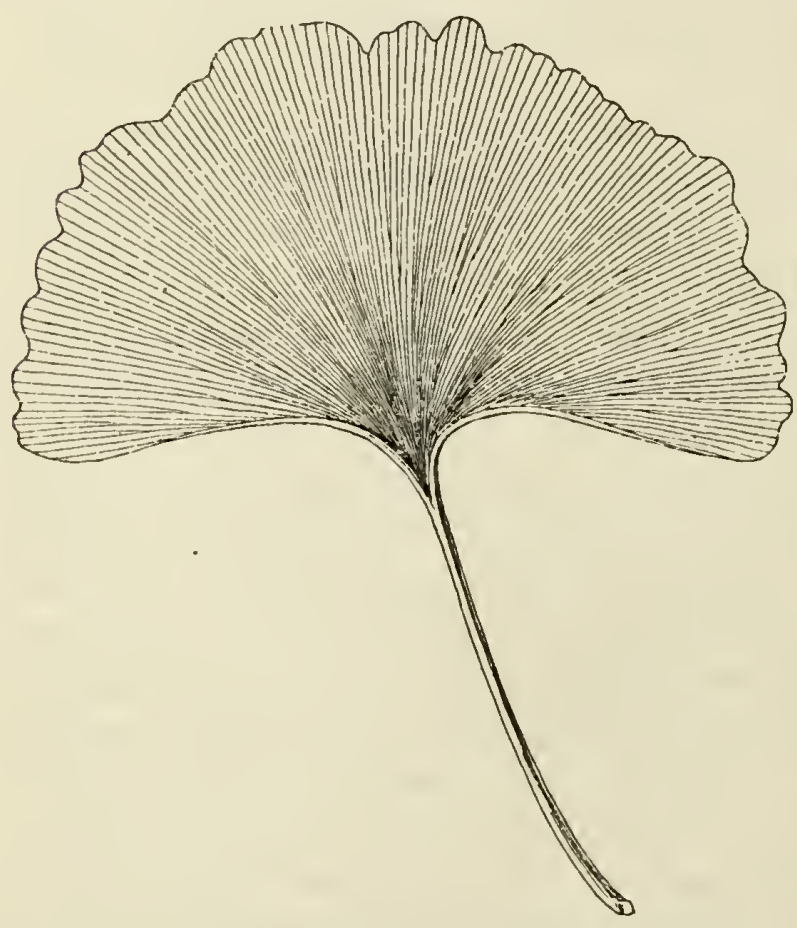

Figure 6.-Ginkgo leaf.

changed from earliest Mesozoic time. It apparently saw its heyday during what is known as the Jurassic period (see table on p. 2), when it was widely spread from the
Arctic regions over most of the globe, but since that time it has been gradually dwindling until it is now represented by a single living species in Japan and China. It is regarded as a sacred tree in the Far East and as such is planted about the temples and sanctuaries, but there is great doubt as to its existence in a truly wild state. It is not likely to become extinct, however, for its fascinating history and curious fernlike foliage (see fig. 6) have made it of so great interest that it has been extensively planted in many parts of the world, notably southern Europe and eastern United States. It is a familiar shade tree on the streets of Washington, D. C.

Among the so-called higher flowering plants there were many grass and sedgelike plants during Fort Union time, but none that were very conspicuous or otherwise remarkable. Other monocotyledonous plants included a fan palm with leaves that must have been 5 or 6 feet across, which once grew along the lower reaches of Yellowstone River in Montana, as shown on Plate XI, $B$ (p. 75).

The plants with deciduous leaves (dicotyledons) flourished in great numbers in Fort Union time, as they do now. They 
West of the summit the surface descends to Richardton, the largest town between Mandan and Dickinson. This town has grown up as a result of the success of dry farming. It is attracRichardton.

Elevation 2,487 feet. Population 647. St. Paul 536 miles. tively situated on the rolling upland plateau of western North Dakota and has abundant supplies of clay and lignite ready to be utilized in the building of a large town.

From Richardton the railway winds through a gently rolling country and gradually descends to Heart River, which is reached Gladstone.

Elevation 2,373 foet. St. Paul 550 miles. at the village of Gladstone. Here the railway is in the same valley that it left a few miles west of Mandan, but the climb out of the valley and the descent back in again saved the railway several miles of track, although it involves some rather heavy grades.

The valley of Heart River is comparatively narrow and is bounded by steep bluffs in which the rocks of the Fort Union formation are

Lehigh.

Elevation 2,372 feet. St. Paul 556 miles. well exposed. At the little village of Lehigh (see sheet 9, p. 64) a lignite mine has been in operation for a number of years. The bed of lignite, which is from 6 to 7 feet thick, lies horizontal and is reached

included trees of many kinds, shrubs, vines, and probably herbs of more humble growth. Among the trees one of the most abundant types as regards kinds as well as individuals was the poplar (Populus). These were of an ancient type, with small rounded or heart-shaped leaves, and were most closely related to the living quaking aspen. Of the willow several species are known. Oaks of several kinds were present, as well as two species of hazelnut, both of which are still living in the eastern United States and Canada. Walnut, allied to our common black walnut, was present, together with sycamores so like the living species as to be separated with difficulty. Figs were present, though not so numerous in North Dakota as they were in other areas where the same formation prevails, notably in Colorado. There were also elms, maples, birches, alders, dogwoods, hickories, box elders, buckthorns, viburnums, wax berries, witchhazels, horse-chestnuts, bittersweets, and many that are without common names.

From this abundant flora it is evident that what is now an almost treeless plain was then covered with splendid forests of hardwoods, interspersed with scattered conifers and ginkgos. From the presence of numerous and in many places thick beds of lignite it is clear that there were great swamps, and that these must have continued with but little change for long periods of time. It has been estimated that the product of heavily timbered woodland, when compressed to the specific gravity of coal, would only amount to about one-fourth of an inch in thickness during a century. If this statement is even approximately correct, it is easy to calculate that a 4 -foot bed of coal must have required about 20,000 years for its accumulation.

Except for the presence of palms and an occasional fig, it might be presumed that the climate was not greatly different from that now prevailing on the Atlantic slope of North America-that is, cool temperate. The palms which are found in the lower part of the formation imply, so far as the present distribution of palms indicates, a somewhat warmer climate, just as the numerous thick beds of lignite throughout the formation imply longcontinued marsh conditions. 
by an entry driven into the hillside. The workings extend 2,000 feet or more into the hill, and the lignite is brought to the tipple in cars hauled by horses. ${ }^{1}$

A few miles west of Lehigh is Dickinson, a district terminal and a thriving town in the midst of an extensive district of dry farms. This place was named for W. S. Dickinson, of Malone,

\section{Dickinson.}

Elevation 2,430 feet. Population 3,678. St. Paul 561 miles.

$\mathrm{N}$. Y., a former State senator and an enthusiastic advocate of the value of the country west of Missouri River. The clay beds worked near Hebron are well developed along the valley of Heart River in the vicinity of Dickinson and are extensively worked a mile south of the town. The clay from this pit is manufactured into dry-press brick and fire brick near the railway just east of the town.

The valley of Heart River is broad and shallow, and few exposures of rocks are to be seen in it, but here and there the bare side of a butte or a freshly cut ravine shows the yellowish sandstone or a bed of lignite of the Fort Union formation.

The climate of the region about South Heart is marked by great extremes in temperature, the mercury ranging from $30^{\circ}$ or $40^{\circ}$ below

\section{South Heart.}

Elevation 2,499 feet. St. Paul 571 miles. zero in the winter to $100^{\circ}$ or more in the summer, but these extremes are not so trying as they would be in a more humid climate. The total precipitation for the year in the part of this region west of Missouri River is about 14 inches, but nearly half of this falls in the winter, leaving only 8 or 10 inches for the growing season. Formerly this amount of rain was considered entirely inadequate for agriculture, but in the last five or six years it has been demonstrated that good crops of grain can be obtained here about three years out of four, if the ground is properly treated. This discovery has changed the activities of the country from stock raising on the open range to the cultivation of grain and the consequent fencing of the country into 160 -acre or 320 -acre tracts.

1 The lignite as it comes from the mine contains about 42 per cent of moisture, but on drying parts with most of it, the percentage being reduced to about 10 . The composition of an average sample of this lignite after it had been dried at a temperature of $86^{\circ}$ to $95^{\circ} \mathrm{F}$. until the sample attained a constant weight is as follows: Moisture, 9.1 per cent; volatile matter, 38.2 per cent; fixed carbon, 42.1 per cent; ash, 10.6 per cent. Its heating value is 9,640 British thermal units. A British thermal unit is the amount of heat required to raise 1 pound of water $1^{\circ} \mathrm{F}$., or it may be considered as the ratio of weight of coal burned to the weight of water that will be raised $1^{\circ}$ by the burning of the coal. Thus the burning of 1 pound of air-dried Lehigh lignite would raise the temperature of 9,640 pounds of water $1^{\circ}$. Coals range in their heating value from the amount given in this analysis, which is about the lowest, to as much as 15,500 British thermal units, a value shown by the best Pocahontas and New River coals of West Virginia. 




GEOLOGIC AND TOPOGRAPHIC MAP OF THE

NORTHERN PACIFIC ROUTE

From St. Paul, Minnesota, to Seattle, Washington

Base compiled from United States Geological Survey Atlas

Sheets, from railroad alignments and profiles supplied by

the Northern Pacific Railway Company and from ampany

information collected with the

UNITED STATES GEOLOGICAL SURVEY

GEORGE OTIS SMITH, DIRECTOR

David White, Chief Geologist

R. B. Marshall, Chief Geographer 1915

Each quadrangle shown on the map with a name in parenthesis in the

lower left corner is mapped in detail on the U.S. G. S. Toppert
BULLETIN 611

SHEET NO. 8

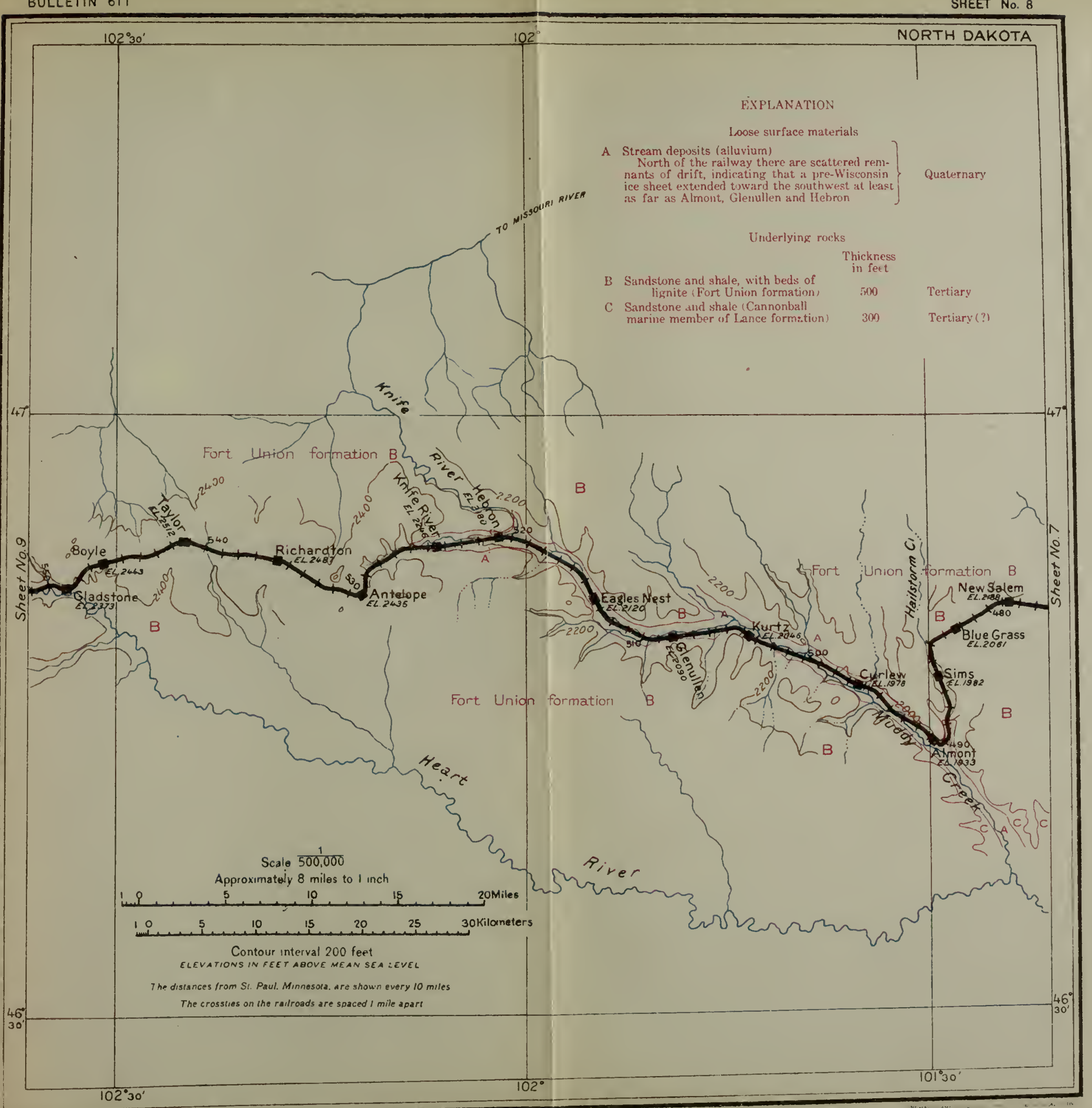



The railway rises steadily up the regular slope by Belfield to the divide between Knife River and Little Missouri River. The valley Belfield. of the Little Missouri is noted for its scenery, but it is Elevation 2,603 feet. St. Paul 581 miles. of even greater interest on account of some of the distinguished people who inhabited it in the days of the open range, when the "cow puncher" was in his glory. Col. Theodore Roosevelt resided for a number of years on a ranch in this valley about 20 miles south of the railway, and here he acquired that knowledge of and sympathy for the free life of the plains that has so endeared him to the western people.

Fryburg is situated on the summit between the drainage basins of Knife River and Little Missouri River. The descent to the Little Missouri is made through a maze of badland forms that Fryburg. stand out in striking contrast to the gentle rolling Elevation 2,790 feet. Population, 288*. St. Paul 587 miles. surface of the upland east of the divide. Little Missouri River has cut its valley about 500 feet deep, and all its tributaries have made similar sharp cuts in the upland, so that the main stream is bordered by a belt of rough country from 10 to 15 miles in width. As the early French explorers and traders had difficulty in crossing these belts they called them "mauvais terres à traverser" or bad lands to cross. From this has come the common appellation "badlands."

The change from the grassy upland east of Fryburg to the badlands of Pyramid Park on Sully Creek is very abrupt, and the traveler is likely to be bewildered by the seemingly endless Sully Springs. variety of form, arrangement, and color. There is Elevation 2,599 feet. an apparent lack of plan in the arrangement of the St. Paul 592 miles.

forms, as if some giant hand had fashioned these monuments and then strewn them about without plan or purpose. Views of the badlands are shown in Plates VI-IX. The natural color is a somber gray, but this is enlivened by bands and splotches of red where beds of lignite have burned. In some places, as at Scoria siding, the burning has been so intense that all the rocks are deep red and huge blocks of half-fused material are abundant. From the evidence on every side one might imagine that at some previous time this place had been an inferno rivaling that of Dante's most vivid imagination, but it is probable that the burning took place so slowly that the general temperature was no greater than it is to-day. It is reported that one of the lignite beds is now on fire at no great distance from the track. If the traveler should come this way on a hot day in August he might well believe that he felt the added heat of the burning lignite, for there is no place hotter than badlands of this character on a hot day, but a cold day in winter would give him a different impression. 
In the badlands many beds of lignite can be seen outcropping as black bands along the faces of the buttes and "temples," and petrified stumps and logs are especially abundant about Sully Springs and near the lower end of the valley. (See Pl. VI, A.) The reason why some of the stumps and logs are petrified is that when the trees fell they were covered by mud before they could decay and for ages were soaked with water charged with silica. This silica replaced the vegetable tissues, preserving even the most minute structures of the plants, so that it is possible to tell to what kind of tree the wood belonged. The petrified logs give a good idea of the size of the trees composing the forests of that day.

The village of Medora is situated on Little Missouri River at the point where it is crossed by the Northern Pacific Railway. The river flows here in a deep, rugged canyon, which seems to Medora.

Elevation 2,290 feet. St. Paul 601 miles. be about the last place in which to establish a settlement. The village was founded in the early eighties by the Marquis De Mores, who named it after his wife. On an eminence on the west bank of the river he built a "chateau," which can be seen on the left (south) from the passing train. The marquis evidently expected that Medora would become a busy center, for he built a large packing house, the remains of which can be seen on the right. He left the country and met a tragic death a few years ago in the Far East.

- There are two prominent beds of lignite in the bluff at Medora, one 40 feet above river level and the other 30 feet higher. The upper bed is 4 feet 6 inches thick and the lower one 9 feet 4 inches, with 3 inches of clay near the bottom. ${ }^{1}$

After crossing the river the road follows Andrews Creek and climbs to the upland in about 16 miles. For most of this distance the rocks of the Fort Union formation are well exposed, and near the river there are exposed the same thick beds of lignite that were seen at Medora. (See Pl. VII, B.)

\footnotetext{
1 The $\log$ of a deep well at Medora, sunk by the railway company for water, records the occurrence of a lignite bed 23 feet thick at a depth of 120 feet. Although beds of lignite from 8 to 9 feet thick are known farther up the river at nearly the same depth and may extend under the town, too much confidence should not be placed on the thickness given in the log of the Medora well, as drillers are not

always careful to distinguish dark shale from lignite. As reported in this $\log$, there is altogether 29 feet of lignite in beds 3 feet or more thick.

The lignite here has been mined only for local use, but when improved methods for the utilization of this kind of fuel have been devised, the canyon of Little Missouri River will offer exceptional opportunities for cheap mining on a large scale.
} 


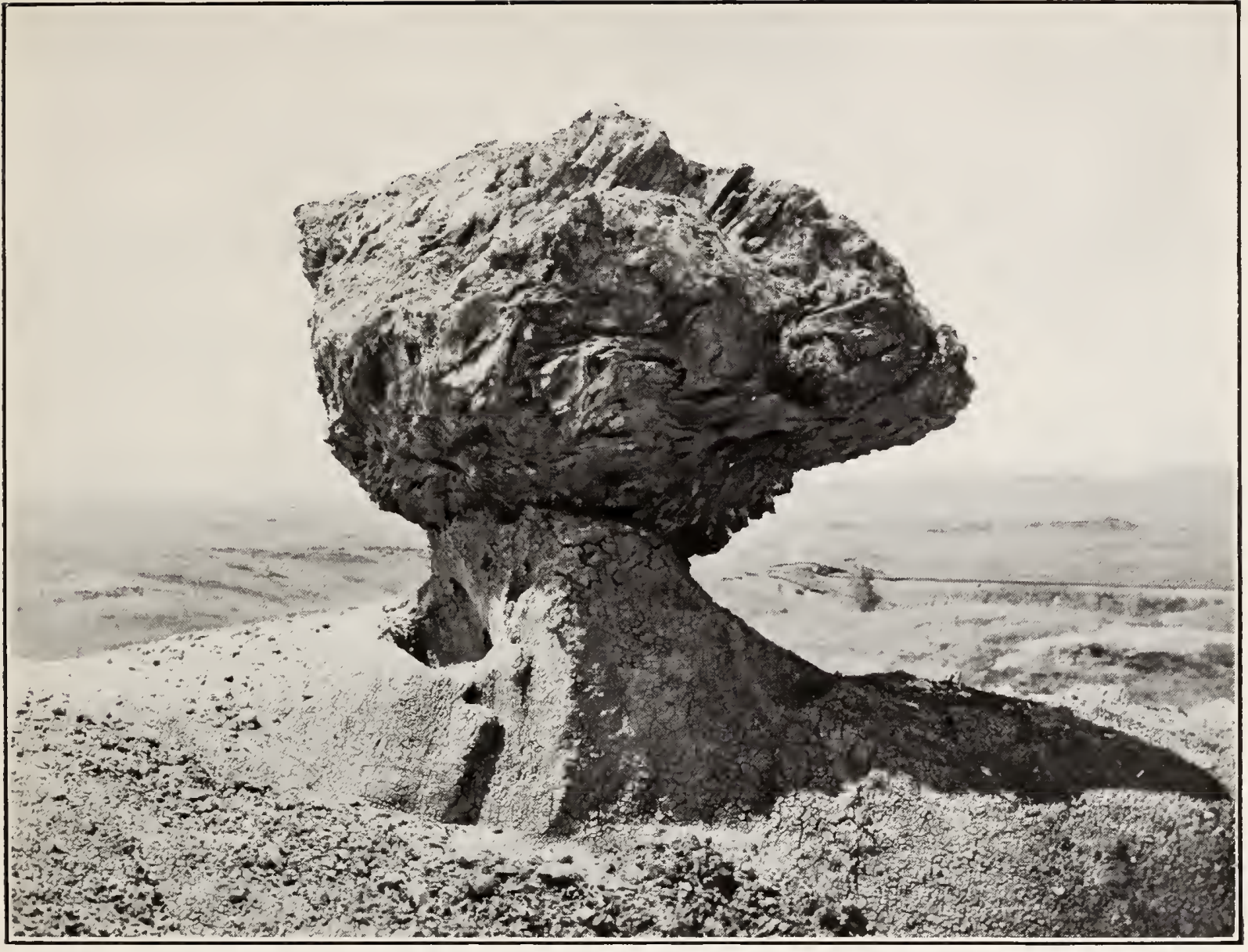

A. SILICIFIED STUMP IN PYRAMID PARK, N. DAK.

A remnant of one of the big trees of the Fort Union forest, now a mass of stone resting on a pedestal cf soft clay. Photograph by Haynes, St. Paul, Minn.

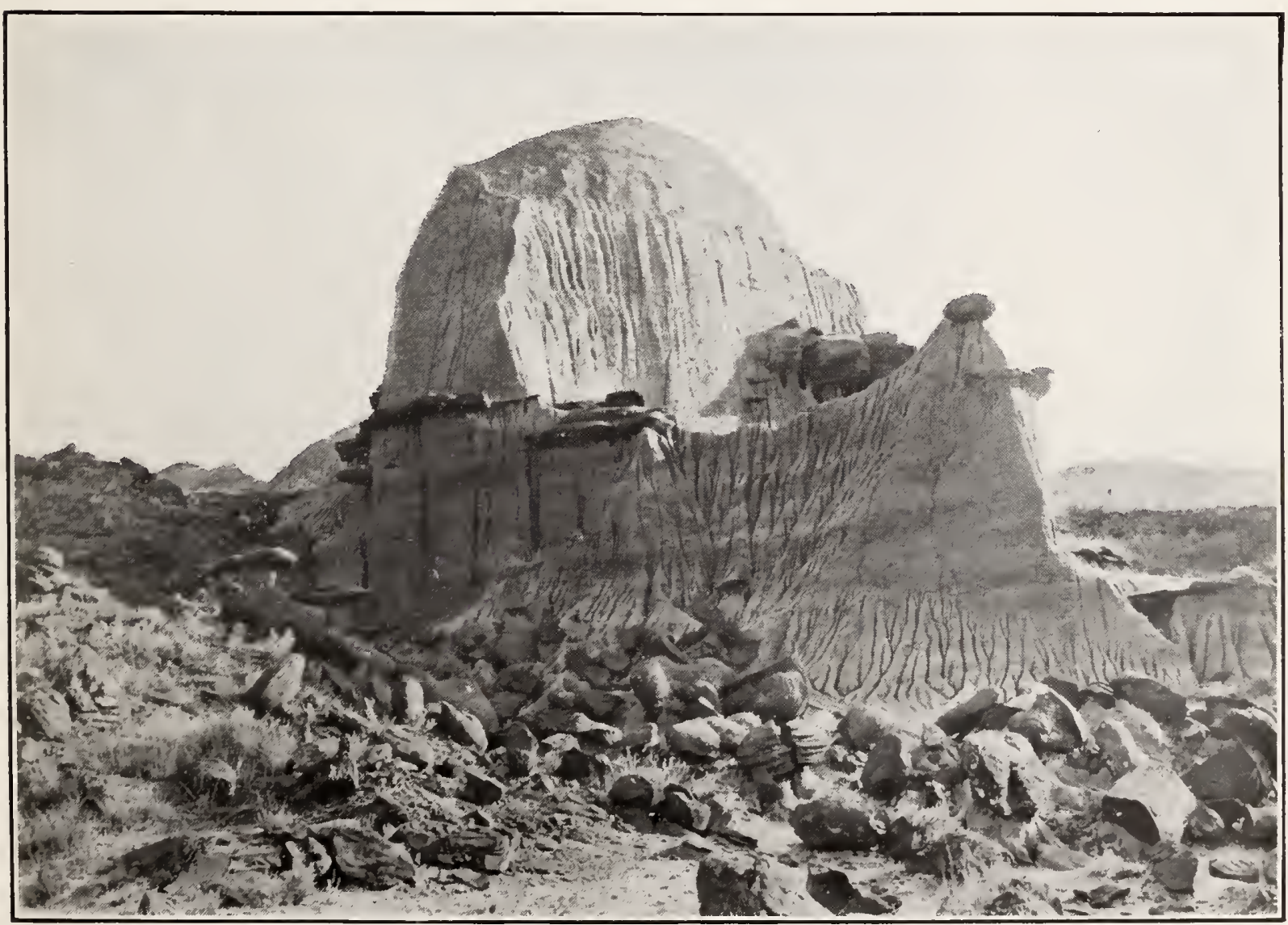

B. THE "PROW OF THE BATTLESHIP," ONE OF THE BUTTES OF PYRAMID PARK, N. DAK.

Note the concretions which weather out of the sandstone and cover the ground long after the main mass has been removed. Photograph by Haynes, St. Paul, Minn. 




A. VIEW OF THE BADLANDS OF NORTH DAKOTA.

Away from the main stream the small side branches and headwater streams are just beginning to cut into the level upland. The wealth of detail in such natural sculpture is beyond description.

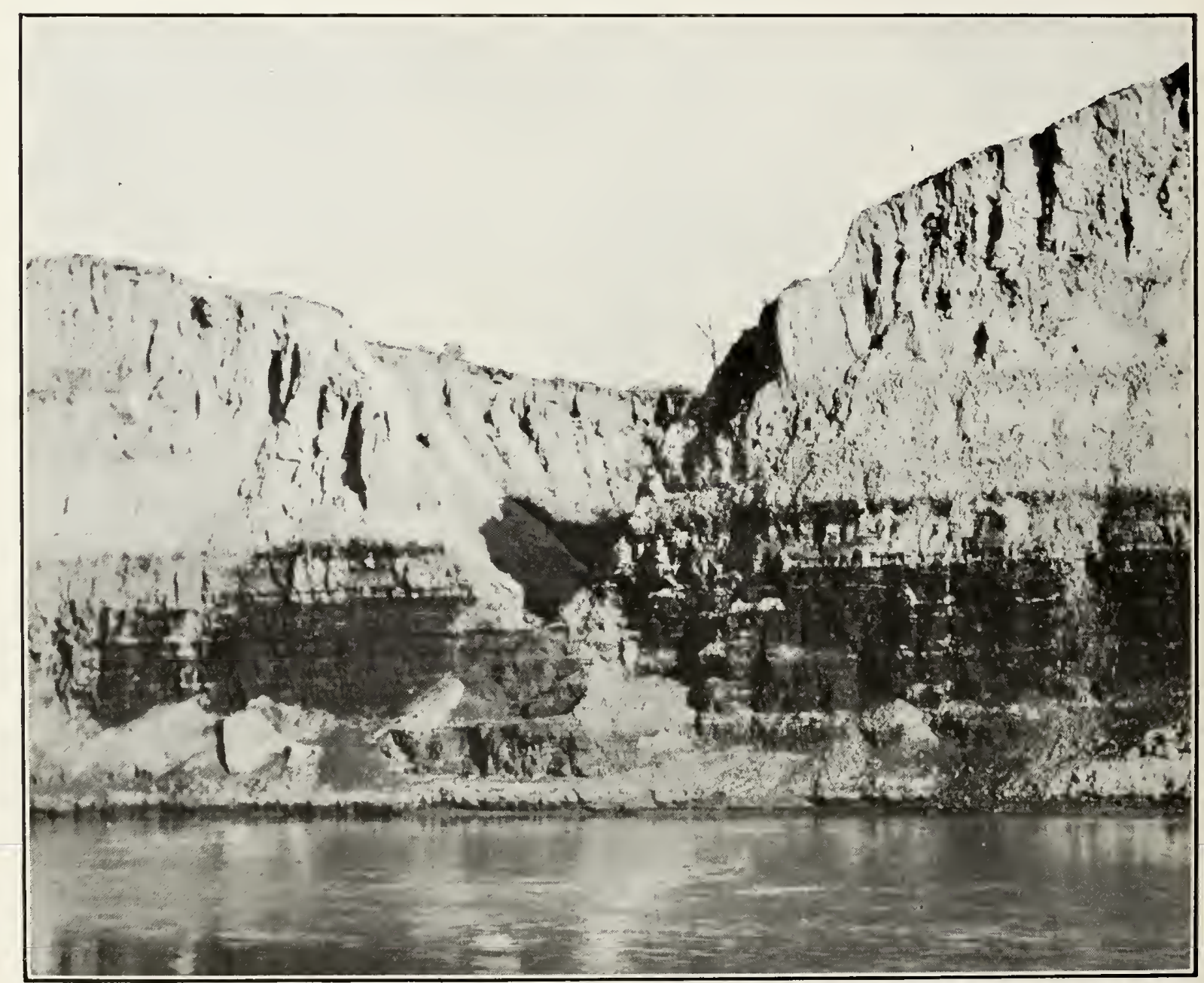

B. A BED OF LIGNITE 15 FEET THICK IN THE CANYON OF LITTLE MISSOURI RIVER, N. DAK. 




A.

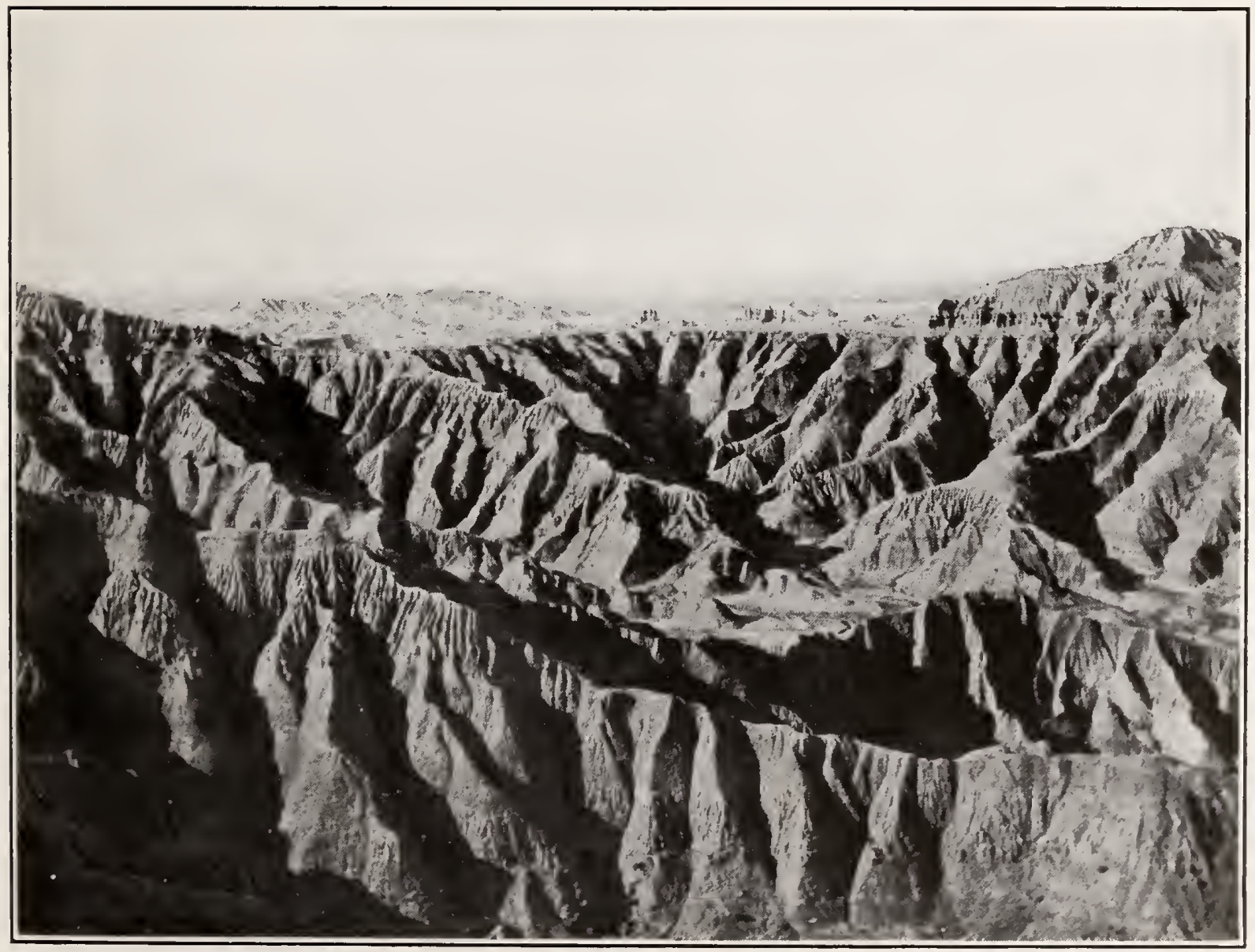

$B$.

VIEWS OF THE BADLANDS OF NORTH DAKOTA.

As shown in the upper view, fantastic shapes abound in every valley and ravine. In places flying buttresses support the slender columns and gargoyles may be seen projecting from beneath the roof. Even with the scanty rainfall of this region, every stream has carved for itself a channel-great ones for the large streams and small, almost infinitesimal ones for the tiny rivulets that trickle down the slope-as shown in the lower view. 


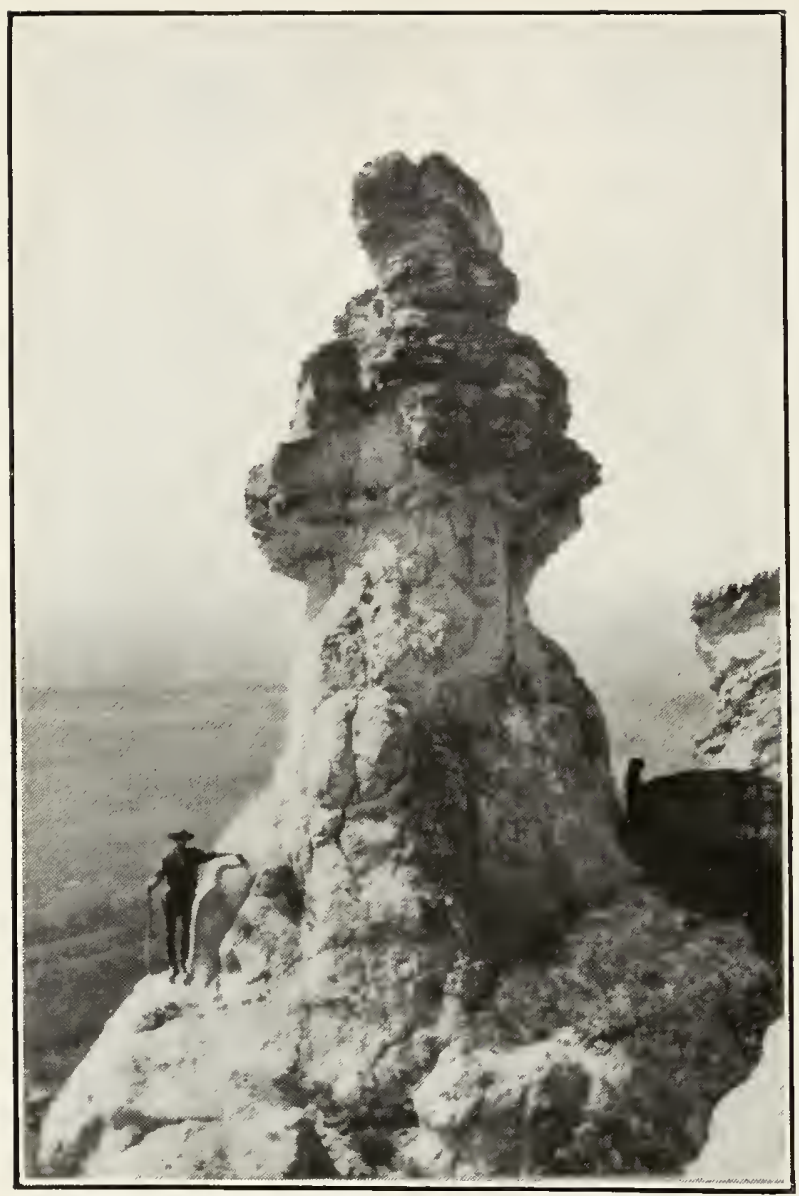

A.

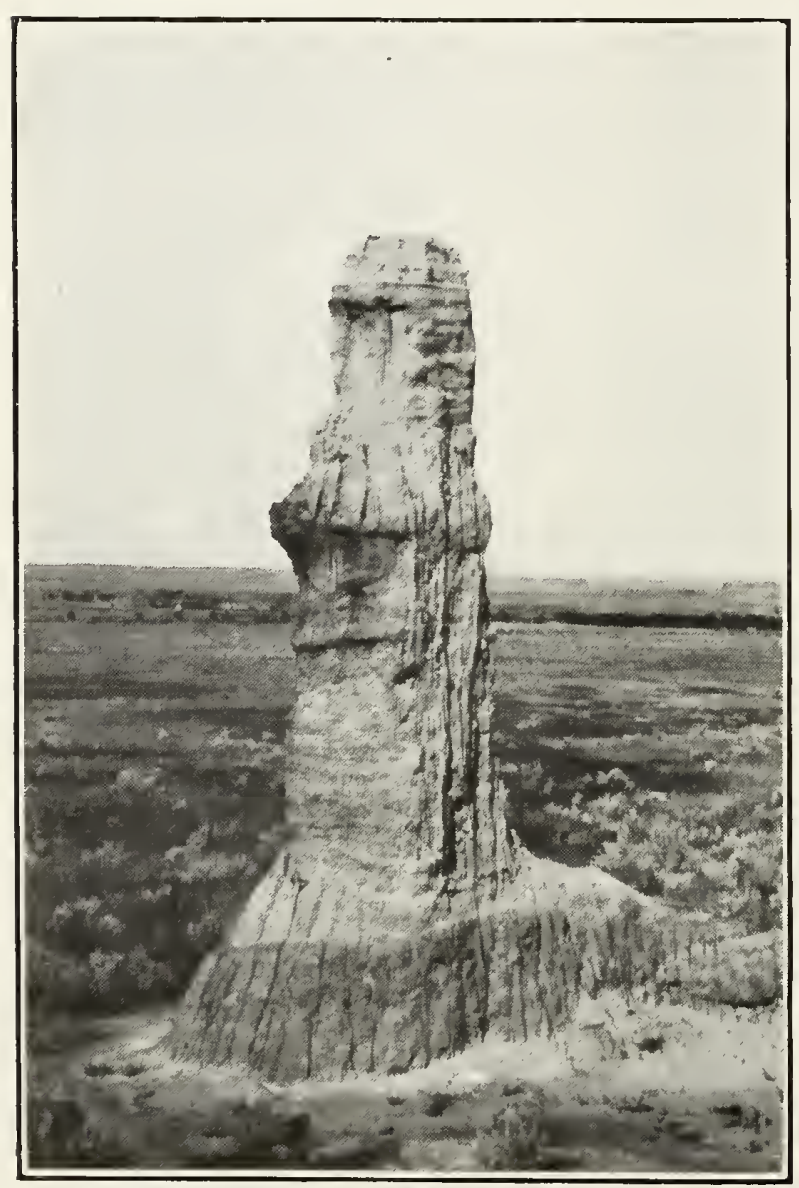

C.

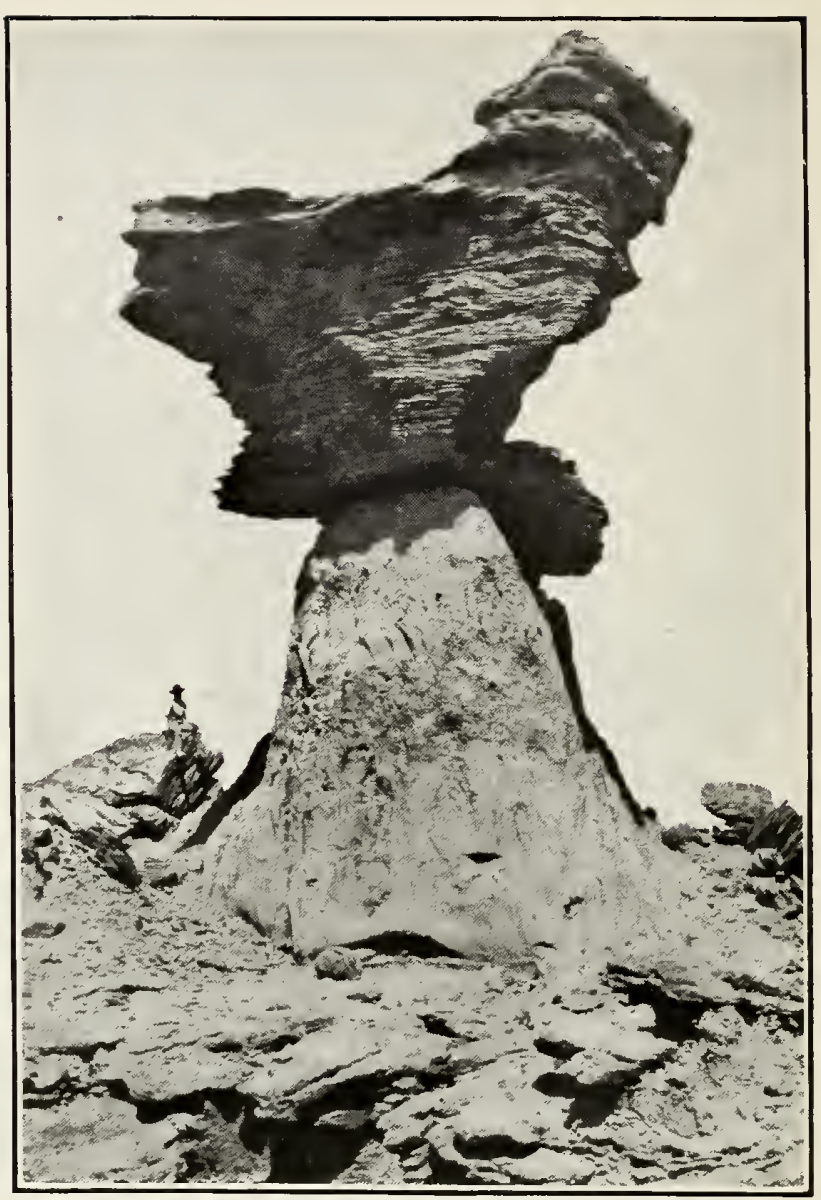

B.

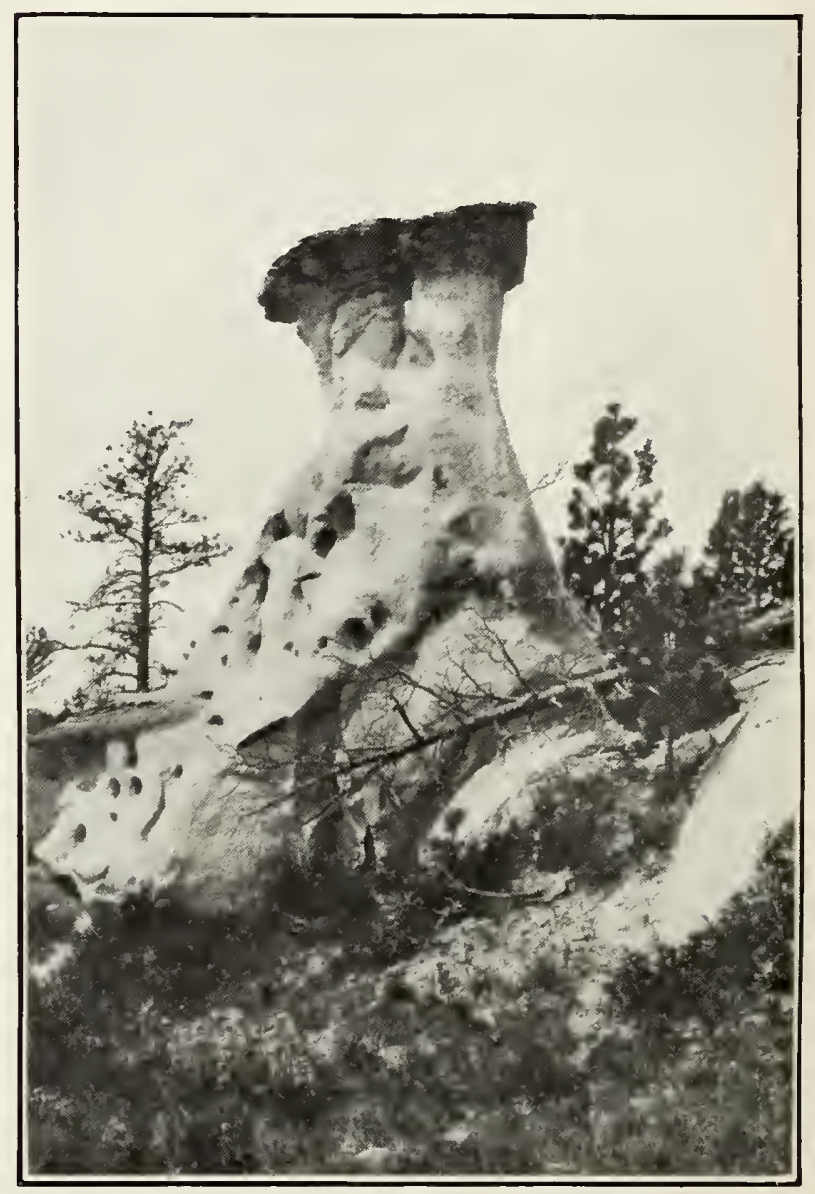

D.

VIEWS OF THE BADLANDS OF NORTH DAKOTA AND MONTANA.

Towers and pinnacles abound on every side. These are the remnants of hills or buttes or of a ledge of sandstone that now remains only as protecting caps to the columns of softer material beneath. 
Near milepost 160 (Demores station) a flat-topped butte can be seen on the left (south) that stands far above most of the other surface features. 'This is known as Square Butte. An irregSentinel Butte. ular, two-crested butte, which is about as high as Elevation 2,731 feet. Square Butte and visible on the right (north), is called St. Paul 617 miles.

Camels Hump. The most prominent and best known of the high knobs in this vicinity is Sentinel Butte, which has an altitude of 3,350 feet, or 620 feet above the town of the same name, and is the highest point of land in North Dakota. These buttes are composed mainly of the Fort Union formation, but they are capped by a thin bed of shale that is supposed to belong to the White River formation, of Oligocene age. The land about the base of Sentinel Butte was a few years ago only a sagebrush plain, but is now divided into farms that in appearance resemble those of the older farming regions farther east.

Beach (see sheet 10, p. 68) is one of the towns that have recently Beach, N. Dak. Elevation 2,779 feet. Population 1,003. St. Paul 626 miles. grown up as a result of the successful farming of this region. West of Beach the railway crosses the State line into Montana, a little west of milepost 176 . The position of the State line is indicated by a sign on the left of the track.

The State of Montana has an area of 146,572 square miles, or a little more than that of the States of New York, New Jersey, Delaware, Pennsylvania, and Ohio. It was admitted to the Montana.

Union in 1889 and according to the census of 1910 had a population of 376,053 . Montana has long been known as a metal-producing State, and many have thought of it as being entirely mountainous and as suited only for mining. As a matter of fact, the western half alone is mountainous; the eastern half, an area nearly as large as North Dakota, is in the Great Plains.

Although placer gold was discovered in Montana in 1852, it was not until 10 or 12 years had elapsed that the "gold rush" began and the outside world was made acquainted with the wondrous wealth of its mountain gravel. Many persons starting for the new gold diggings stopped in the more promising valleys, such as the Gallatin and the Bitterroot, and farming began almost as soon as the panning of gold. The mining industry of the State has passed through a number of changes from placer mining to lode mining of gold and silver and, finally, of copper as the leading metal. Before the development of the great copper mines at Butte, Michigan was the leading State in the production of copper, but it soon gave place to Montana, which for a number of years stood at the head. Recently Arizona has forged to the front and Montana has dropped to second place in the rank of copper producers. Despite the fact that Montana ranks second in 
the amount of copper produced annually, it still is first in the total amount produced. The total for the three leading States up to the close of 1913 is as follows: Montana, 3,214,775 tons; Michigan, 2,759,721 tons; Arizona, 2,324,719 tons.

At first agriculture flourished only in the mountain valleys, where there was protection from the frost and the wind, and the plains portion of the State was devoted to the grazing of stock. Immense herds of cattle roamed the plains, and for a number of years Montana held first place in the number of sheep and the value of the wool shipped out of the State. Irrigation was finally undertaken in many of the valleys, and large crops of wheat, oats, alfalfa, and sugar beets are now being raised. The most recent change has been the influx of the dry-land farmer and the taking up and fencing of most of the land in the eastern and central parts of the State. This has materially decreased the number of live stock, and in the sheep industry Montana has dropped to second place, Wyoming taking the lead. Dry farming has not been universally successful, but sufficient has been accomplished to demonstrate that it is feasible when rightly carried on and with sufficient capital to enable the farmer to tide over years of drought and crop failure. The most important crop in the State is forage, amounting in 1909 to over $\$ 12,000,000$.

Probably few persons realize that the value of manufactured articles in Montana exceeds that of the output of the mines, but such is the case. The smelting and refining of copper are the leading industries, but the value of the manufactured product is not given in the census reports. It is, however, roughly the same as the output of the mines. Aside from the manufacture of copper, the leading manufacturing industry is that of lumber and timber, which in 1909 amounted to over $\$ 6,000,000$. The values of the products of the State, exclusive of the copper smelted and refined, are about as follows: Manufacturing (1909), $\$ 73,000,000$; mining (1913), $\$ 69,000,000$; agriculture, (1909), $\$ 63,000,000$.

The country continues to be rolling to the valley of Beaver Creek, a tributary of Little Missouri River, on which is situated the town of Wibaux (we'bo), in the midst of an excellent farming Wibaux, Mont. district. Four miles west of Wibaux the railway Elevation 2,674 feet. crosses the summit between the drainage basin of Population 487.

St. Paul 636 miles.

Little Missouri River on the east and that of Yellowstone River on the west, and then begins a long descent down Glendive Creek to the Yellowstone. This valley was a famous hunting ground in early days, and the name Glendive was applied to it by Sir George Gore, an Irish nobleman, who hunted buffalo here in the winter of $1855-56$. 


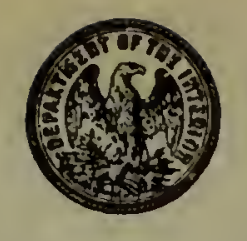

GEOLOGIC AND TOPOGRAPHIC MAP OF THE

NORTHERN PACIFIC ROUTE

From St. Paul, Minnesota, to Seattle, Washington

Base compiled from United States Geological Survey Atlas Sheets, from railroad alignments and profiles supplied by

the Norther Pacific Railway Company and from addition

UNITED STATES GEOLOGICAL SURVEY

GEORGE OTIS SMITH, DIRECTOR

David White, Chief Geologist R. B. Marshall, Chief Geographer

1915

Eaoh quadrangle shown on the map with a name in parenthesis in the lower le/l cormer is maphed ind doll on ane U. S. C.

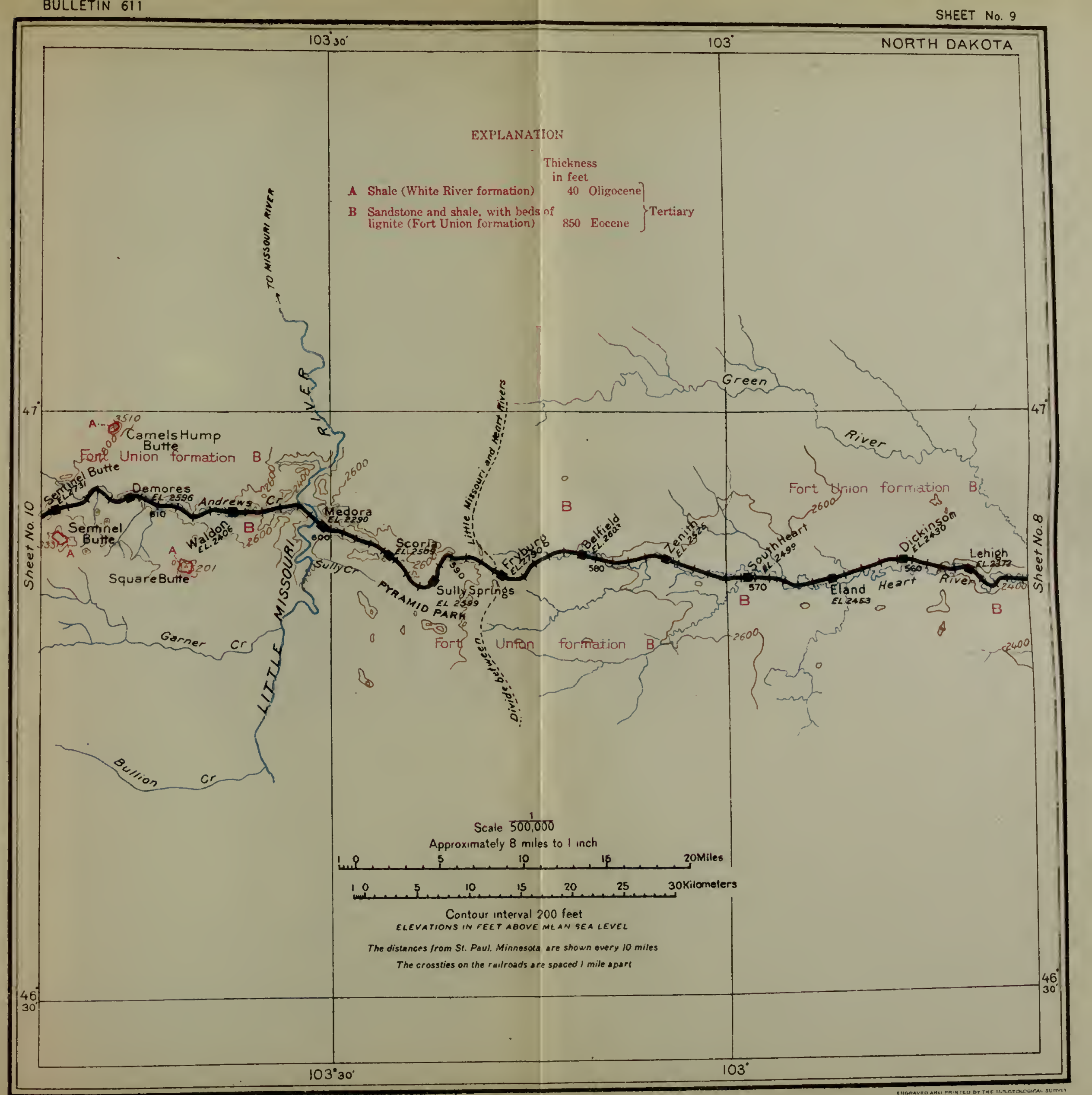



The rocks, which to the eye appear to be horizontal, in reality rise steadily toward the southwest as part of a broad and gently curved arch in the strata, more fully described on page 68 . The rise of the rocks in this direction brings to the surface those crossed in the badlands east of Medora and others that lie below the level of Little Missouri River at that place, but the country is so generally grass covered that the traveler can not see them all.

At Hodges there is a bed of lignite which is supposed to mark the base of the Fort Union formation, and may be the same as the bed reported to be 23 feet thick under Medora. The rocks below this bed, which are scarcely distinguishable from the rocks above, belong to the Lance formation, in which the valley of Glendive Creek is cut from Hodges to Yellowstone River. In most places the valley is bounded by bare walls of somber-colored rocks and subdued badlands, but they are neither so imposing nor so picturesque as those of Pyramid Park. The Lance formation carries some beds of lignite, but generally they are too thin to mine.

Below Allard the Lance formation constitutes the valley walls as far as Yellowstone River. Along this part of the valley no two of the Allard. topographic forms are the same, but there is a simiElevation 2,269 feet. St. Paul 657 miles. larity of type and color that soon becomes extremely monotonous. There are, however, some well-defined terraces which in a measure tend to relieve the dullness of the landscape. The upper terrace probably records an epoch when the stream was flowing at a higher level than it is to-day, these terraces being remnants of the old valley floor. The lower terraces, which are well developed near the river, may record flood stages of the Yellowstone, when slack water from the river backed up into all the tributary valleys and caused sand and mud to be deposited.

At milepost 213 the train swings out from the mouth of Glendive Creek into the broad valley of the Yellowstone and in a few minutes reaches Glendive, the end of the division, the county

Glendive.

Elevation 2,091 feet. Population 2,428 . St. Paul 667 miles. seat of Dawson County, and one of the largest towns in eastern Montana. In building the main line of the Northern Pacific Railway in 1879-80 this was the most important town between Missouri River and Helena, for it was the point from which construction was carried on in both directions. This was made possible by the transportation of supplies from Bismarck by way of Missouri and Yellowstone rivers. When through travel was established, however, Glendive lost most of its importance, and for a long time its growth was slow, as the country roundabout was but sparsely settled and its principal business was that of a division terminal of the railroad. Recently, with the impetus given to agriculture by the introduction of dry-farming $40063^{\circ}-$ Bull. $611-16-5$ 
methods and with the completion of the Lower Yellowstone irrigation project by the United States Reclamation Service, ${ }^{1}$ settlers have flocked in, and the country which 10 years ago was an open range is now almost all cut up into small farms. This change has removed from this region one of the picturesque types of western life-the "cow-puncher" of the early days. The traveler may still see a few poor imitations or caricatures, but the real article-the fearless, daredevil rider who was an equally fearless "booze fighter" when he came to town-is no more. The big herds are gone, and with them the men who tended them.

At Glendive the railway route again touches the trail of Lewis and Clark, for in their homeward journey Capt. Clark with a small party descended Yellowstone River. ${ }^{2}$ As nearly as can be determined, they passed the site of Glendive on August 1, 1806.

South of Glendive there can be seen on the left (east) badland bluffs and on the right the muddy river, which, a short distance above the town, is crossed by the new branch railway leading to Intake and other towns established under the Lower Yellowstone irrigation project. Still farther south the railway passes through deep cuts in massive white sandstone and skirts a prominent pinnacle of the same rock,

${ }^{1}$ In the Yellowstone Valley in eastern Montana, tributary to the Northern Pacific and Great Northern railways, the Government has built an irrigation system to cover a strip of land 70 miles long lying on both sides of the river and extending over the boundary line into North Dakota. The irrigable area consists of about 60,000 acres of land lying in the midst of one of the best and largest grazing areas in the United States.

The soil is a deep sandy loam and when properly cultivated produces abundant crops of hay and grain. Alfalfa, the great forage crop of the West, grows to perfection here, and dairying and the winter feeding and fattening of stock are profitable industries.

The towns of Intake, Burns, Savage, Craneville, Sidney, and Fairview, Mont., and Dore, N. Dak., are in the area covered by the project. Nearly all the Government lands have been filed upon, but several hundred farms are for sale on easy terms and at reasonable prices. The cost of water right is $\$ 45$ an acre, payable in annual installments to the Government.

The general el evation is 1,900 feet above sea level, and the temperature ranges from $30^{\circ}$ below to $100^{\circ}$ above zero. The advantages of the valley in the way of fertile soil, assured water supply, favorable climate, low prices, and transportation facilities make it one of the most desirable locations in the Northwest.

2 The name Yellowstone was doubtless given to the river because of some outcrop of yellow rocks along its banks; but where do such rocks occur? The traveler in passing up the valley sees no distinctly yellow rocks between Glendive and Livingston, and if he goes to Yellowstone Park he will see none as far as Gardiner, the northern entrance to the park. Within the park the conditions are different. The canyon of the Yellowstone below the falls is noted the world over for its gorgeous display of colors, among which the most brilliant and dominating tint is yellow. Here is the only place on the river where the rocks are so distinctly yellow as to have suggested a name for the stream, and the conclusion seems inevitable that here the name originated.

As the evidence available seems to indicate that the name did not originate with the English explorers, it must have been given by some early French traveler 
known as Eagle Butte. This white sandstone with a buff layer at the bottom is known to geologists by the local name of Colgate sandstone. The lower part contains in places casts of sea weeds and marine shells, so that it is believed to represent the sandy shore of an ancient sea. It is supposed to be in part equivalent to the Fox Hills sandstone of South Dakota. The rocks overlying the Colgate sandstone in this region are all of fresh-water origin. At Eagle Butte the sandstone appears to be nearly horizontal, but it rises gently toward the southwest and near milepost 7 it is high in the hills, and the shale below it appears at railroad level. The hill near milepost 7 , known as Iron Bluff, is noted for the beauty and abundance of the fossil shells that occur in limestone concretions ${ }^{1}$ in the dark shale. The shells are so perfectly preserved that they retain their pearly luster. From the kinds of shells occurring in the shale and from its character it is known to be the same as the dark shale that is poorly exposed in the river bluffs at Valley City, N. Dak. It is called the Pierre shale and is of Upper Cretaceous age. The fossil shells show clearly that the sea must have occupied this part of the country when the shale was deposited. At that time, instead of rolling prairies across North Dakota and eastern Montana, there were rolling waves and abundant marine life.

or by the Indians who inhabited the region. The only Frenchman who is thought to have seen the upper part of the Yellowstone Valley before the time of Lewis and Clark was Verandrye, who, between the years 1738 and 1742 , penetrated the wilderness far to the west of Lake Winnipeg and who wandered for a long time among the mountains in an ineffectual attempt to reach the Pacific slope. It is said that he reached the headwaters of the Missouri and even penetrated as far south as the central part of Wyoming, where he was so beset by hostile Indians that he was forced to return to the east.

None of the points described by Verandrye have been recognized, so the identity of the country which he traversed will always remain a matter of doubt. It seems incredible, however, that he should have visited the site of the present Yellowstone Park without noting at least some of the wonderful geysers and hot springs. On this negative evidence it is reasonable to conclude that he did not visit the canyon of the Yellowstone, and therefore that the Indians were the first people to apply the name.
${ }^{1}$ The term concretion is applied to rounded bodies of rock that are somewhat harder and more resistant than the main mass of the formation in which they are contained and for that reason remain on the surface after the rest of the formation has decayed. In many places they are nearly spherical, but as a rule they are irregular in outline, either elongated in a mass resembling the trunk of a tree or flattened like a disk.

The material composing concretions differs greatly; in sandstone or sandy shale it is generally sand, or sand containing a large amount of iron; in limestone it is generally chert (a form of silica); in shale it consists of limestone or ironstone. The concretions of Iron Bluff are doubly interesting because they are made up almost exchusively of fossil shells. It seems probable that the shells grew in colonies and thus provided the lime of which the concretions are composed. The result is very beautiful and many of the coiled shells are so perfect that they might inspire another IIolmes to write a poem on the chambered nautilus of the ancient sea. 
The Pierre shale continues to Cedar Creek, 11 miles beyond Glendive, where, if the traveler looks ahead on the left at milopost 11, he will see on the far side of the valley a large ridge in which the rocks dip as much as $20^{\circ}$ in the direction in which he is going, the opposite direction from their dip between Glendive and Cedar Creek. In other words, the train has crossed a great arch or anticline in the rocks, the highest point of which is at Cedar Creek. The Glendive anticline is the most pronounced fold in eastern Montana. It extends from Yellowstone River in a straight line southeastward into the extreme northwest corner of South Dakota. It brings to the surface the Pierre shale on the center of the arch, and as this shale is softer than the rocks on either side, it gives rise to a belt of country having little relief. For this reason it was followed by the Chicago, Milwaukee \& St. Paul Railway from Marmarth, N. Dak., to Baker, Mont. The shale is everywhere rimmed about by the hard Colgate sandstone, and this in turn by the Lance and Fort Union formations. The form of this fold is shown in figure 7, which represents

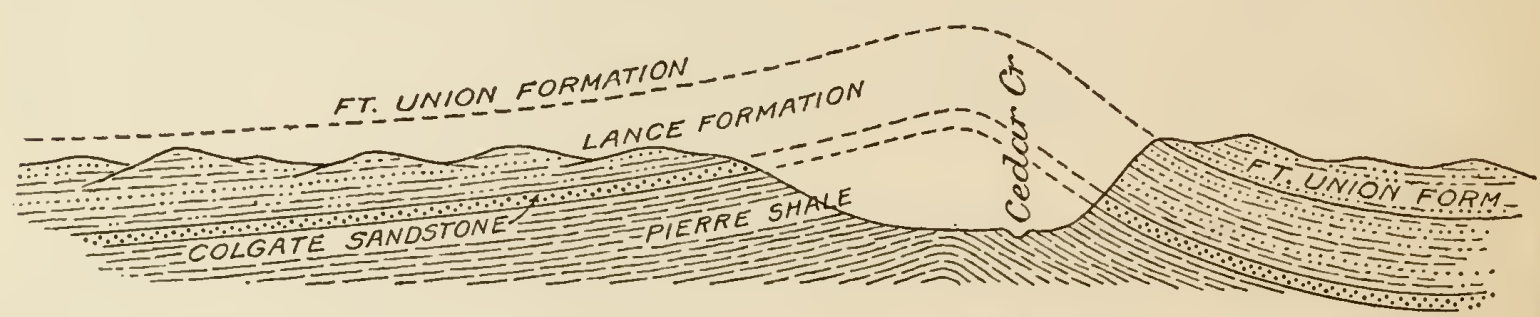

FIGURE 7.-Diagram of Glendive anticline, Mont., looking east. Gentle dips on northeast side; steep dips on southwest side.

the strata as thoy would appear if the observer were in an airplane hovering over the flat on the far side of the river and looking up the valley of Cedar Creek to the southeast. A short distance beyond the mouth of the creek the steep dips die out and the rocks are so nearly flat that they seem to be horizontal.

At milepost 17, between Hoyt and Marsh, there is a large gravel pit on the left from which ballast has been hauled as far east as Richardton, N. Dak. This gravel, as well as that occurring at other places along the river, contains many moss agates which have been washed down from the mountains in the vicinity of Yellowstone Park, and many fine specimens have been picked up along the track. Just beyond the village of Fallon (see sheet 11, p. 72) the Chicago, Milwaukee \& St. Paul Railway enters the valley of Yellowstone River from Fallon Creek, and near milepost 36 it

\section{Fallon.}

Elevation 2,231 feet. Population 531.* St. Paul 697 miles. crosses the Northern Pacific tracks by an overhead bridge. In this vicinity, as elsewhere in the Yollowstone Valley, two plants characteristic of the semiarid West are very abundant, the cottonwood tree (Populus) and the sage (Artemisia). The courses of the river and its tributaries can be followed across the prairies where the bluffs 

are low by the lines of cottonwood trees, and even in the lower part of the mountains these trees are generally found where there is running water. Sagebrush originally covered most of the bottom land of the valley, but it has been removed in many places to make room for valuable crops. Many people suppose that the growth of sagebrush is indicative of poor soil, but such is not the case, and a person familiar with the habits of the plant will always prefer a plot of land on which the sagebrush grows to large size.

The village of Terry, named in honor of Gen. Alfred H. Terry, who commanded the expedition of 1876 in what is commonly known as the Custer campaign, is served by both the North-

Terry.

Elevation 2,264 feet. Population 775.* St. Paul 706 miles.

ern Pacific and St. Paul roads. The light-colored sandstones which give to the Fort Union formation its distinctive color are well developed between Cedar Creek and Terry, but at Terry, in the lower part of the formation, there begins a change in color and composition that will become more evident as the traveler proceeds westward. ${ }^{1}$

About 2 miles above Terry the Chicago, Milwaukee \& St. Paul Railway crosses Yellowstone River, and it remains on the far side nearly to Miles City. The big coal bed at the base of the Lebo shale may be observed on both sides of the valley as far as the mouth of Powder River and on the opposite side of the river for some distance beyond that point. The rocks rise gradually upstream, and within a short distance the Lebo shale, which is only a little above river level at Terry, rises so high that it disappears from the adjacent bluffs and the underlying Lance forms all the hills that are in sight between Powder and Tongue rivers.

In the vicinity of Miles City is Signal Butte, a high knob about 4 miles southwest of the railway, which can be seen from passing

1 The large lignite bed on the west side of the river, which can readily be seen fiom the train near Terry, is regarded as the base of the Fort Union formation. Beginning a short distance down the river below Terry, there appears just above this bed a band of dark shale which increases in thickness up the river to 50 feet in the bluff opposite the town and to 200 feet a mile or so farther west. The traveler, if he looks closely, can recognize this more somber-colored belt. It is made up of dark shale and sandstone, which, when examined under a microscope, are found to contain a large quantity of volcanic material in the form of lava fragments and volcanic dust or ash. These particles have been washed and rolled over in water until all have been reduced to fine mud or sand. This band of dark material has been followed westward nearly to its source, which must have been somewhere in the vicinity of Yellowstone Park. In that region the formation is much thicker than it is farther east and the materials composing it are coarser, as would naturally be expected of material dropped near the shore. South or southwest of Livingston there were at one time great volcanic outbursts, and the material thus thrown out was swept away by the currents of water and deposited in a layer that extended for a great distance toward the east. This widespread sheet of volcanic sedimentary material is known as the Lebo shale member of the Fort Union formation. 
trains. It is reported that in the early days, before the railway had been built into this region, officers from Fort Keogh (ke'o) used this butte for sending and recciving messages from the Black Hills, 175 miles distant. The signaling was done with a heliograph, an instrument for reflecting the sun's rays in any desired direction and flashing messages in the Morse code. On account of this use the knob reccived its name.

Miles City, at the mouth of 'Tongue River, was named in honor of Gen. Nelson A. Miles, an expcricnced Indian fighter, who had already established Fort Keogh on the river bottom

Miles City.

Elevation 2,377 feet Population 4,697 .

St. Paul 746 miles. about 2 miles farther west. Miles City is said to be the greatest horse market in the West, and is also an important wool-shipping point. In the early days the principal industry was the hunting of the buffalo or bison, and it is reported that as many as 250,000 hides were shipped

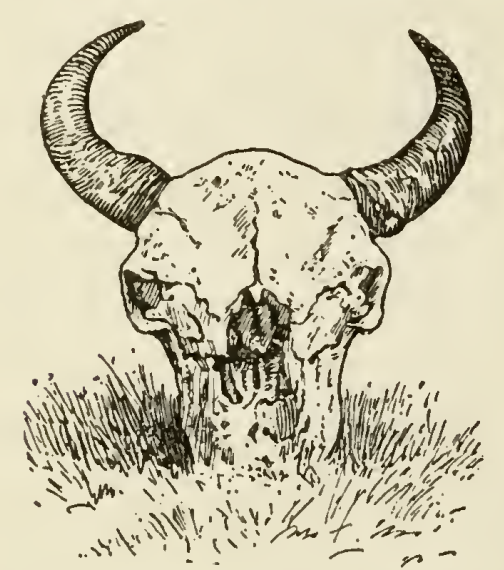

Figure 8. - Sun-bleached skull near Miles City, Mont. The skulls and bones are all that remain of the great herds of buffalo that once roamed these plains.

from this place in one scason. Such numbers are almost inconceivable, but it is well known that the buffalo roamed the plains in great herds, and when the slaughter was carried on in wholesale fashion the number killed must have been very great. Capt. Clark and his party, in descending the Ycllowstone in boats, were forced to wait near Glendive until a herd of buffalo numbering, by his estimate, 80,000 had crossed the river. Now all traces of the buffalo are gone from these plains except an occasional sun-blcached skull or a few weather-beaten horns. (Sec fig. 8.)

Some distance below Tongue River the St. Paul road crosses the Yellowstone, and Miles City has the advantage of two transcontinental railways.

West of Tongue River, on the right (north), is Fort Keogh, which was built by Gen. Miles in 1877 and named in honor of Capt. Myles W. Keogh, who perished in the Battle of the Little Bighorn the year before. For a long time this was probably the most important post in the Indian country, but now it is used only as a remount station, where horses are trained for cavalry service.

The St. Paul road crosses to the north side of the Yellowstone again a short distance above Fort Keogh, and it remains on that side of the stream to Forsyth, where it turns northwestward and crosses the divide to Musselshell River. The Northern Pacific line continues on the south side, running in places along the wide, flat bottoms and in others on the river bank, where it is overhung by cliffs and steep slopes of sandstone, shale, and coal beds of the Lance 
formation. Generally the coal beds are thin or variable in thickness; but in places they thicken, as between mileposts 92 and 93 , where four beds are visible from the train. Two or three of these beds are thick enough to work and some day may be mined, although the coal is not of very high quality. It is much better, however, than the lignite of North Dakota or that around Glendive and is classed as subbituminous-a grade between lignite and ordinary bituminous coal.

A similar change in the character of the coal or lignite can be found in almost all the fields of the Rocky Mountains and the Pacific coast. In every field the coal improves in quality toward the mountains, in places ranging from lignite to subbituminous coal or from subbituminous coal to anthracite within the limits of a single field. Such changes are doubtless due to greater stresses in the rocky crust of the earth in the mountains than in the plains, and as the coal is the weakest member of the rocks forming that crust it was most compressed and changed.

The chief interest in the trip from Miles City to Rosebud lies in the fact that the railroad was constructed along the same route as that followed by Custer in his approach to the great battle that terminated his career. ${ }^{1}$

${ }^{1}$ In the spring of 1876 the Sioux Indians exhibited signs of unrest, and some of the more adventurous spirits among them deserted their reservations and began to assemble a force which the Government feared might at any time take the warpath and cause pillage and slaughter along the frontier. Sitting Bull was the leader of the insurrection. Gen. Crook with 1,000 men at Fort Fetterman (near Douglas), on North Platte River, Wyo.; Gen. Terry with another 1,000 at Fort Abraham Lincoln, near Mandan, N. Dak.; and Gen. Gibbon with 450 men at Fort Ellis, near Bozeman, Mont., were ordered to force the Sioux back to their reservations.

The command of Gen. Crook, the greatest Indian fighter of his time, was defeated by the Indians in a battle on the headwaters of Rosebud River June 17, before he could effect a junction with the other parts of the expedition. He tried to notify Terry and Custer of his defeat and to warn them of the great number of Indians engaged in the campaign, but his scouts failed to reach them, and Cus- ter proceeded from the mouth of Tongue River (Miles City) June 19, supposing the Indian force to be a small one which he could overcome in a single daring charge. Custer had just returned from Washington, where he had had difficulty with his superior officers, and, doubtless smarting under the charges made against him and the indignity of a threatened court-martial, he was in the mood to stake all on the chance of winning an immediate and brilliant victory. Maj. Reno, of his command, had been on a scouting trip into the Rosebud Valley, where he found abundant indications of a party of Indians who had recently moved westward toward the Little Bighorn.

On June 21 Custer's command camped at the mouth of Rosebud River, where they were joined by the troops under the command of Gen. Gibbon. The plan of the battle was for Custer to move up the Rosebud until he found the trail reported by Reno and then to follow it until he reached the Indian camp, which was supposed to be on the Little Bighorn. Gibbon's command was to march back on 
West of Fort Keogh the railway follows the river past the small villages of Hathaway and Joppa to Rosebud, at the mouth of Rosebud River. (See sheet 12, p. 78.) The scenery along

\section{Rosebud.}

Elevation 2,501 feet. Population 370.*

St. Paul 778 miles. this part of Yellowstone River is not particularly striking, but many interesting views may be obtained, especially if the trip is made late in the season, when the water is low, for at that time it is generally clear, whereas in June the stream, swollen by the melting snow in the mountains, becomes a muddy torrent. Streams in this condition may be interesting as vehicles for the transportation of earthy material, but they are certainly not attractive.

Where the river swings close against the rocky bluffs the traveler may obtain through the soft foliage of the willows and cottonwoods vistas of deep, quiet pools that reflect all the colors of the clouds and sky, or of tumbling rapids where accumulated bowlders interfere with the progress of the stream. These views have for a setting on one side bold and rugged cliffs and on the other the upland stretching away to the horizon in a monotonous expanse of dry and dusty plain. In other places the outlook is over the wide valley bottom, which irrigation has made an oasis in the desert of sagebrush hills and broken cliffs.

the north side of the Yellowstone to the mouth of Bighorn River, and there Terry and Gibbon were to meet them on the steamer Far West and ferry them across the river. Gibbon was then to lead his command up the Bighorn and strike the enemy from the north at the same time that Custer made his attack on the east and south.

Custer did not pause at the mouth of the Rosebud but was away the next morning on his march up that stream. After following it for about 70 miles he found the great trail that the Indians had made across the ridge toward the Little Bighorn. He did not wait to give Gibbon time to move his troops up from the mouth of Bighorn River but pressed on until the Indians were actually sighted in an enormous camp on the Little Bighorn. Here he divided his forces, directing Reno to descend to the stream at the upper end of the camp and sweep down the valley, while he scouted along the hills on the east, apparently intending to attack the Sioux from that side simulta- neously with Reno's charge and put them to flight.

Reno failed in his effort to drive the Indians down the valley and early in the action took to the hills on the east, where after considerable fighting he managed to secure a position that he held throughout the engagement. The whole force of the Indians was then directed against Custer, and he, as well as his entire command, with the exception of an Indian guide, were slain. Reno was besieged in the hills until he was rescued by the force under Gibbon, which arrived, howevar, too late to take an active part in the battle. When Gibbon's troops arrived the Indians left the valley and after some skirmishes with the soldicrs returned to their reservations.

The soldiers killed in this battle numbered 265. They are buried in a national cemetery on the spot where they fell, with fitting monuments commemorating the bravery of their last fight against overwhelming numbers. 

The Lance formation makes rugged bluffs along the river frorn Miles City to Forsyth. This formation extends across North Dakota, Montana, South Dakota, and Wyoming. The coal or lignite beds that characterize it in many places and the fossil leaves and branches that have been found almost everywhere in the sandstone and shale composing it show clearly that it was laid down in lakes and ponds. It is also certain that at the time it was deposited great forests flourished over much of the area of the States mentioned, where are now the treeless wastes of the Great Plains. The trees of that time were similar to those of the Fort Union epoch, as described on page 57. The formation of coal beds means that the land was flat and probably at low level. The plains country and much of that which is now mountainous was at that time low and swampy, supporting a luxuriant tangle of large trees, underbrush, vines, and water plants. The strange creatures that roamed through that ancient forest or swam in its shallow lakes are described below by Charles W. Gilmore, of the United States National Museum. ${ }^{1}$

${ }^{1}$ Where vegetation grew as luxuriantly as in the swamps and lowlands of Lance time there must have been animals to subsist upon it and in turn other animals to feed upon them. The Lance formation is noted for the remains of great reptiles that it contains, and all the large museums of the country have skeletons or models of these wonderful dinosaurs, as they are called.

One of the best-known dinosaurs is called Triceratops (meaning literally three-horned face), so named because he had over each eye a massive horn directed forward and terminating in a long, sharp point and a third, but much smaller horn, on the nose, not unlike that of the modern rhinoceros. A mounted skeleton of Triceratops in the National Museum in Washington is about 20 feet long and stands 8 feet high at the hips. Some of the skulls that have been found measure more than 8 feet, or nearly one-third of the length of the entire animal, including the tail. The great length of skull is due to the fact that the neck was protected by a bony frill, which projected backward from the skull like a fireman's helmet or like the large ruffs that were worn in Queen Elizabeth's time. Although the brain of this dinosaur is large, it is, when the size of the skull is taken in to consideration, relatively smaller than that of any other known land animal.

That Triceratops was a fighter is shown by the finding of broken and healed bones. A pair of horns in the National Museum bear mute witness to such an encounter, for they had been broken and then rounded over and healed while the animal was alive.

In the earlier restorations or models of this animal, as shown in Plate X (p. 74), the skin was represented as being smooth and leathery, but in a specimen recently discovered the well-preserved skin shows that it was made up of a series of scales of various sizes.

Triceratops, as indicated by the structure of his teeth, was manifestly a planteating animal, his food probably being leaves and branches of low trees and shrubs. Hatcher, the most noted collector of Triceratops in the United States, has pictured the country at the time these animals lived as being made up of vast swamps with wide watercourses that were constantly shifting their channels, the whole resembling the Everglades of Florida. The entire region, where the waters were not too deep, was covered by an abundant vegetation and inhabited by the huge dinosaurs as well as by crocodiles, alligators, turtles, and diminutive 
During Lance time the crossing of the continent must have been atiended by dangers beside which those of the African wilds seem trivial indeed. The traveler may be glad that he is safely ensconced in a railway car instead of facing the terrible ferocity of some wandering dinosaur as big as a house. But the days of these monsters have passed away, and their former presence is recorded only in the skeletons which here and there are found embedded in the rocks. Just across the river from Forsyth a skeleton of Triceratops was found

animals, fossil remains of which are now found embedded in the sand and mud that were deposited in those old swamps.

There lived at the same time the great duck-billed reptile Trachodon, the bestknown and presumably the commonest dinosaur of its time. The length of an average-sized individual, measured from the end of the nose to the tip of the tail, was 30 feet, and as he walked erect on his huge three-toed hind feet, the tip of the head, which was nearly a yard long, was from 12 to 15 feet above the ground. The nose expanded into a broad duck-billed beak, which was covered with a horny sheath, as in birds and turtles, and was admirably adapted to pulling up the rushes and other water plants upon which the creature lived. That 'Trachodon lived in the water is shown by the webbed fingers of the fore foot and the long, deep, flattened tail, which was a most efficient swimming organ and equally useful as a counterbalance to the weight of his body when he was striding about on his hind legs on the land. The skin, as shown by specimens that have been found, was thin and covered with tubercles of two sizes, the larger ones predominating on surfaces exposed to the sun. One of the most remarkable features of this great brute was the set of teeth with which he was provided. In that respect he was much better off than the human being, for as soon as a tooth was worn out or lost, it was replaced by another pushed up from below. Each jaw had from 40 to 60 rows on each side and from 10 to 14 teeth in each row, hence there must have been more than 2,000 teeth in the mouth of one individual.

There were also fiesh-eating and consequently armored reptiles in Lance time.
The most highly specialized of the armored reptiles was Ankylosaurus, which was covered by a great number of flattened ridged-skin plates of bone, arranged in rows across the broad back. The reptile was low of stature and had at the end of his stout, heavy tail a great triangular club of bone, which when he moved about must have dragged on the ground. The head was short and blunt, and the eye was provided with a cup-shaped bony shutter that could be closed over the eyeball when the creature was harassed by his enemies. With all vulnerable parts thus protected by bony armor, this living fortress had little to fear from his bloodthirsty contemporaries. Ankylosaurus doubtless had need of his armor, for there were many other flesh-eating dinosaurs that swarmed in the forests or swam in the sluggish waters. The most striking of these was Tyrannosaurus, or tyrant lizard, the largest land-walking carnivorous animal the world has ever known. He was 40 feet long and, in a standing position on his hind legs, was 18 or 20 feet high. The fore legs were exceedingly small, and he must have walked entirely upon his powerful hind legs, the knee joint of which was 6 feet above the ground. At the American Museum of Natural History, New York, there is a perfect skull of this animal. It is with a feeling of awe that the spectator stands before the huge head with jaws 4 feet long, filled with bristling rows of sharp-pointed teeth, several of which project at least 6 inches from their socket, and he can not help wondering what part such a creature played in the economy of nature and whether he was as important to his time and place as the animals that live to-day. 


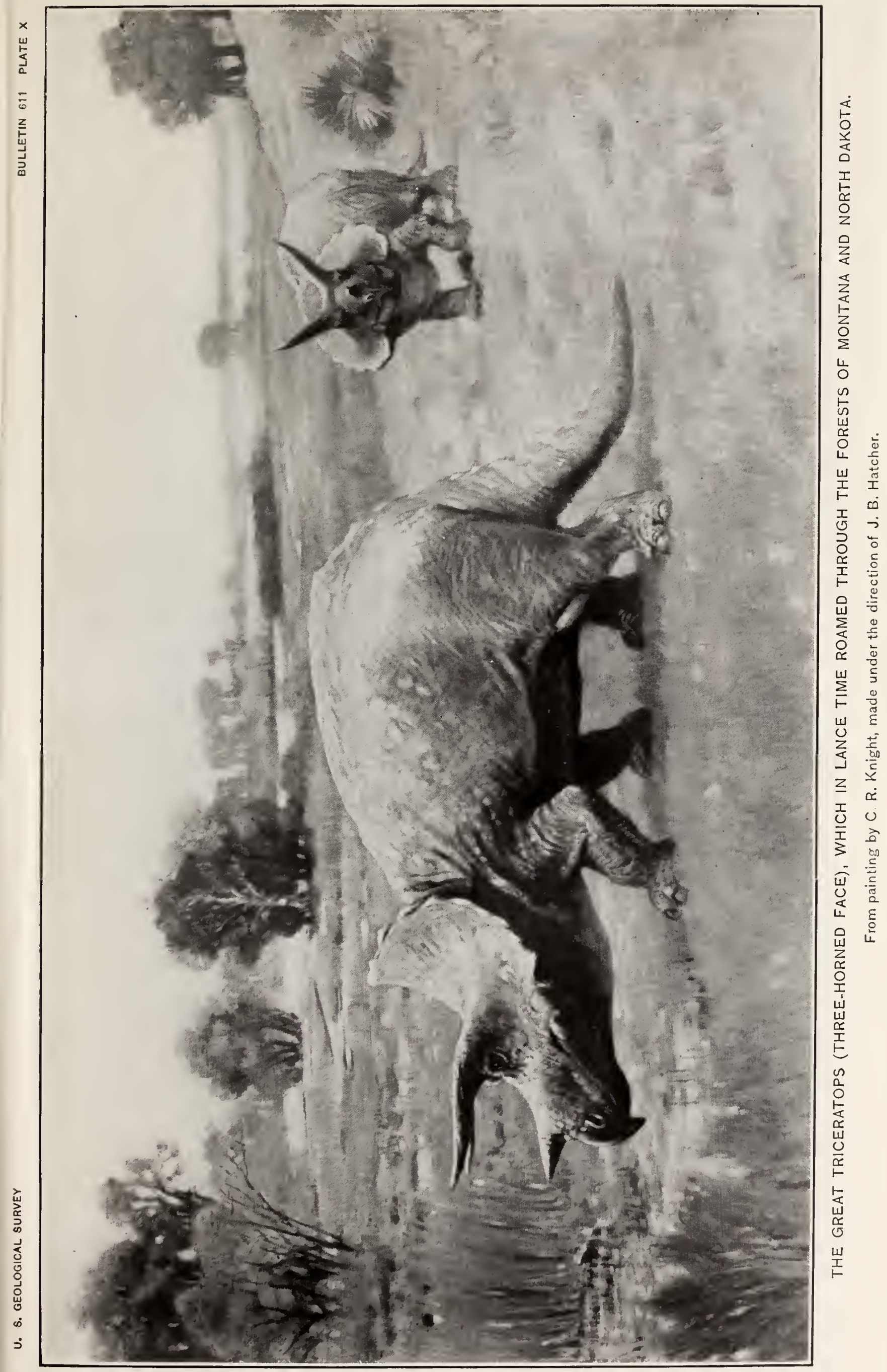




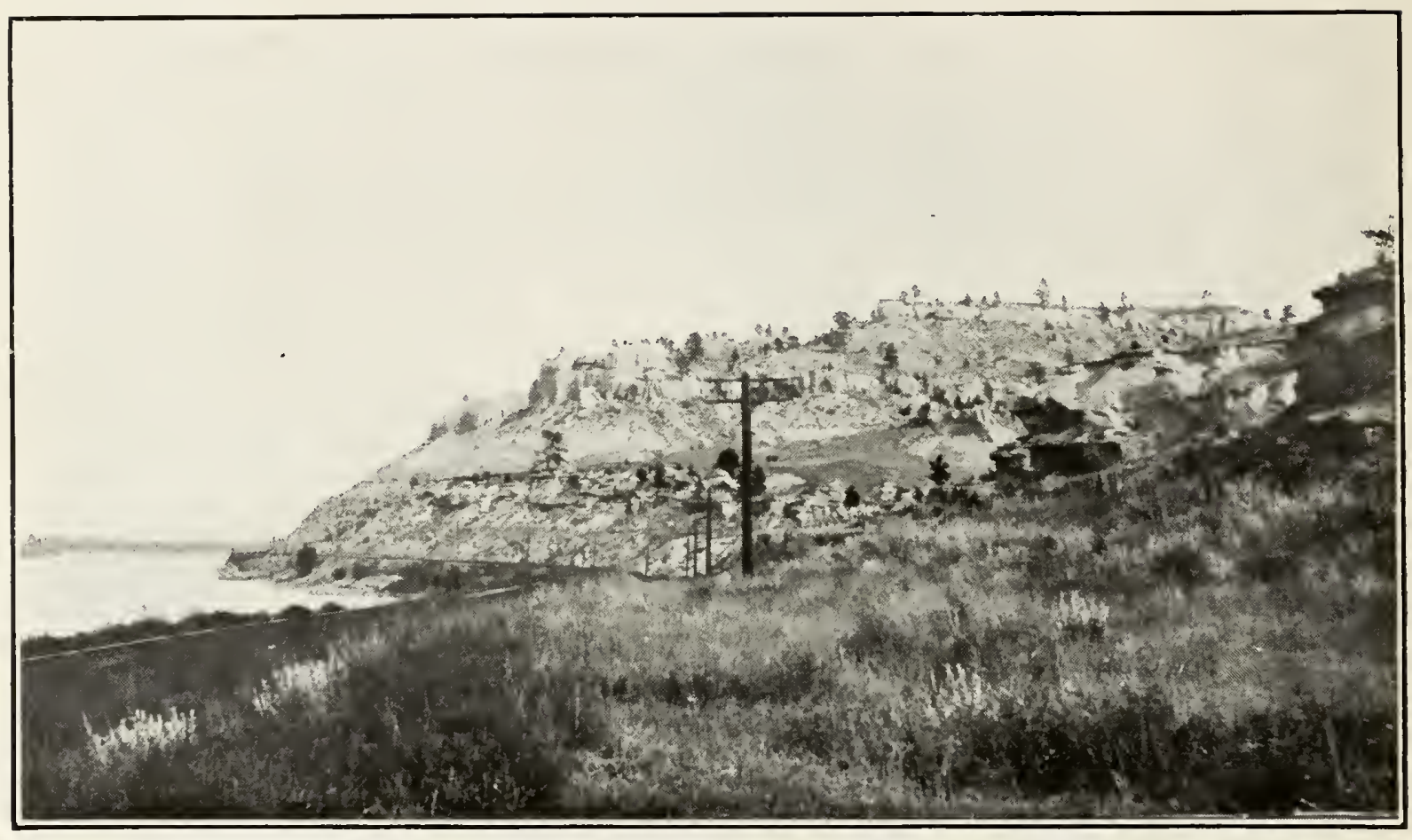

A. BLUFFS OF LANCE FORMATION ON YELLOWSTONE RIVER WEST OF HYSHAM, MONT.

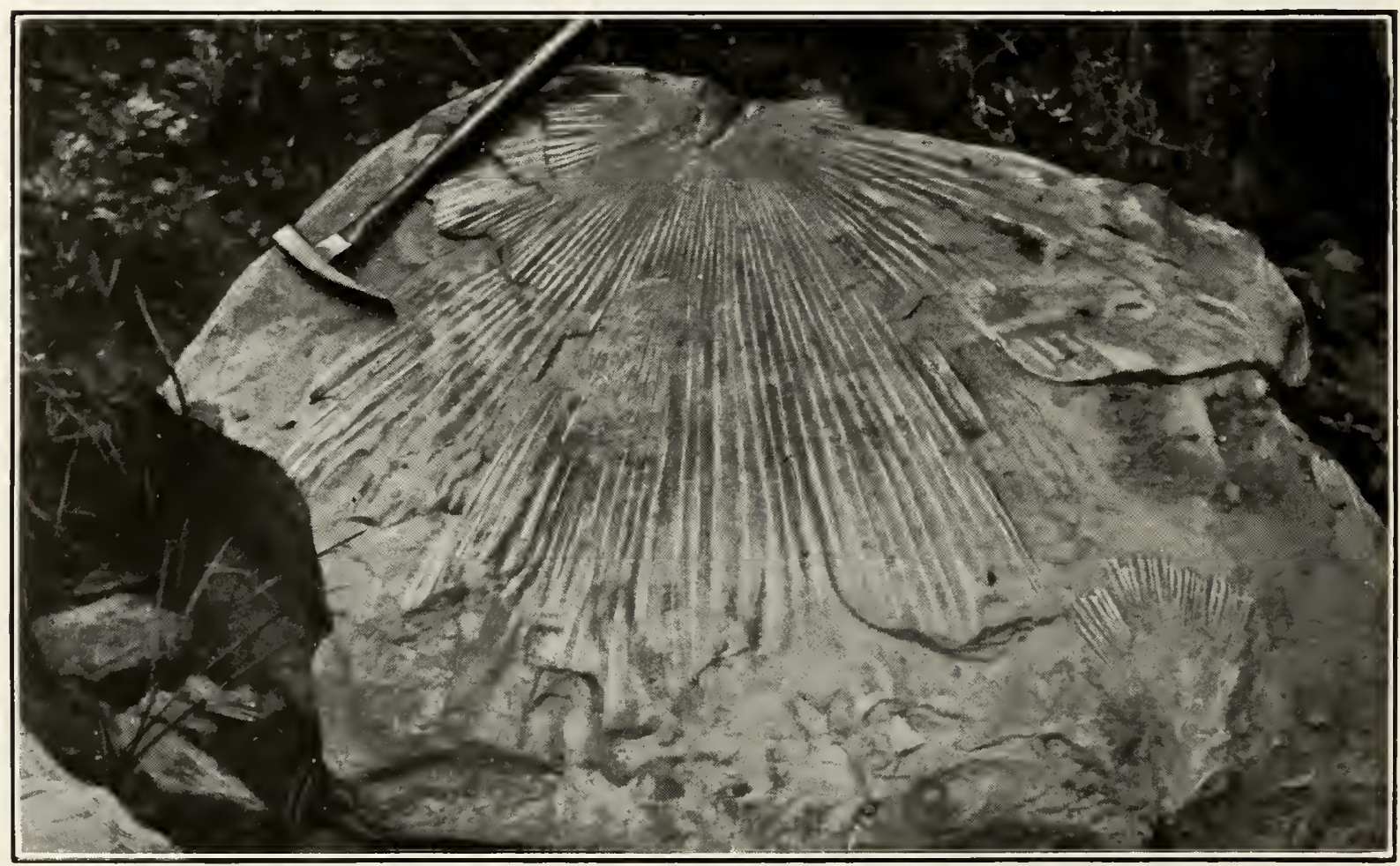

B. FOSSIL PALM LEAF OF EOCENE AGE FOUND NEAR HYSHAM, MONT.

The climate of Montana must have been warmer and more moist than it is to-day to have permitted the growth of palms and other subtropical plants. 
several years ago, and bones of these animals may be scen occasionally in riding about the country.

Forsyth, the county seat of Rosebud County, a district terminal of the Northern Pacific Railway, is one of the thriving towns in the Yellowstone Valley. It was named for Gen. J. W.

Forsyth.

Flevation 2535 feet $\quad$ try. Opposite the town the Chicaso, Mitwaukeo Population 1,393. try. Opposite the town the Chicago, Milwaukee \& St. Pau] 791 miles.

St. Paul Railway, which has followed Yellowstone River from Terry, leaves the valley and goes in a northwesterly direction to the Musselshell Valley in the vicinity of the new towns of Musselshell and Roundup.

Beyond Forsyth an anticline crosses the Yellowstone Valley, but it is not so distinct as the one above Glendive. The first indication that the traveler may observe of a change from the Lance formation, which is at railway level from Terry to Forsyth, is that after passing Armells Creek, just beyond milepost 130, the width of the valley suddenly increases and the bluffs lose their rugged character. These features indicate the presence of softer rocks, and while the formation containing them is not visible from the train a close examination of the bluffs would show that they are composed of dark shalc-the same dark shale that the traveler saw at Cedar Creek, above Glendive. This shale normally underlies the Lance, and its presence near railway level here means that the rocks rise west of Forsyth and the next lower formation is brought to view. ${ }^{1}$

1 The dark shale noted near Glendive is called the Pierre shale, but the dark shale that makes its appearance near Howard and is said to be the same as the Pierre, is called Bearpaw. The change

supposed to represent the cut edges of the formations as they lie in the ground.

In the Black Hills, and so far as known at Glendive, the Upper Cretaceous rocks begin with the Dakota sandstone at the

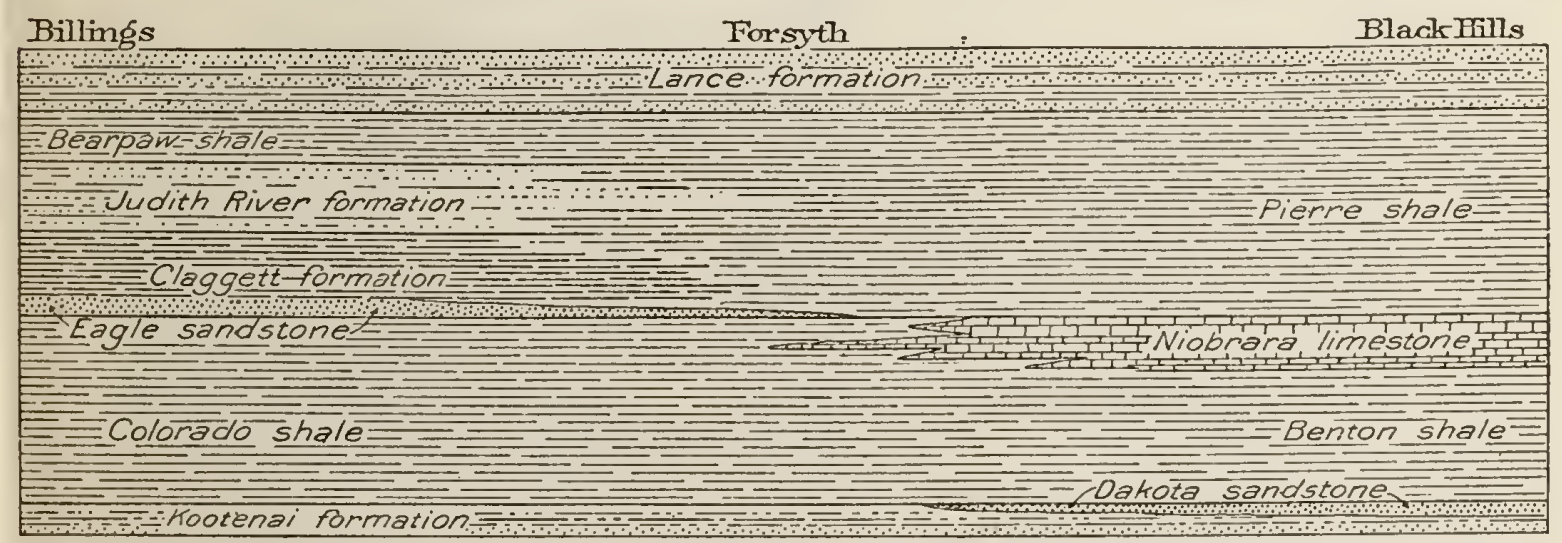

FIGURE 9.-Diagram showing the thinning out and coming in of formations from the Black Hills, S. Dak., to Billings, Mont.

in the Cretaceous formations along an east-west line from the Black Hills to Billings, Mont., and the reason for the introduction of new names for the formations are explained by figure 9 , which is base, resting upon the Lower Cretaceous. Over this are two great shales (Benton and Pierre) and a limestone (Niobrara) of marine origin, and capping all is the Lance, a fresh-water deposit. 
The high hills composed of Lance sandstones (see Pl. XI, A, p. 75), as shown on sheet 12 (p. 78), récede from the river until at Howard they are more than 2 miles from the railway, and Howard. the low hills near by are made up of the Bearpaw Elovation 2,600 feet. Population 139.* St. Paul 800 miles. shale. The outcrop of the shale crosses the river and then swings far to the northeast around a domeshaped structure in the rocks that brings this and lower formations up to the surface.

The valley increases in width until in the vicinity of Finch the Lance sandstones are so far back from the river that they are hidden by the low hills of shale at the margin of the valley

Finch.

Elevation 2,595 feet. St. Paul 806 miles. bottom. At milepost 141, a short distance east of Sanders, a massive gray sandstone rises from river level until it attains a height above the railway of about 30 feet. Beyond this point it descends toward the west and within a short distance disappears below railway level. The highest point on this sandstone marks the axis of a large irregular uplift which lies almost entirely north of the railway.

This sandstone is known to be the extreme eastern point of the Judith River, a coal-bearing formation (see fig. 9) that is exposed in many places in the central part of the State. In its best development it is a fresh-water deposit, but the sandstone near Sanders contains marine shells, showing that the shore of the land upon which the fresh-water sediments of the central part of the State were laid down was near this place, and that to the east of that shore line sand was deposited in the waters of the sea. A deep well recently drilled for water at Vananda, on the Chicago, Milwaukee \& St. Paul Railway about 16 miles northwest of Forsyth, started in this sandstone and struck the red shale of the Kootenai formation (see fig. 9) at a depth of about 3,200 feet.

The relatively flat land in the bottom of this valley, although originally only a sagebrush plain, was attractive to farmers, and an extensive private irrigation project has been developed. Water is taken from the river at Myers, between Hysham and Rancher, and

Westward from the Black Hills the Niobrara fades out as a limestone, and at Billings it can not be identified and separated from the Benton. The entire mass of shale is called the Colorado, and this is equivalent to both the Benton and the Niobrara. The Dakota disappears west of the Black Hills and the Colorado shale rests upon the Kootenai (Lower Cretaceous).

In the east the great marine deposit above the Niobrara is known as the Pierre shale. Toward the west this changes in character in its lower part, and three more or less sandy formations-the Eagle sandstone and the Claggett and Judith River formations-have been recognized and named. The dark shale above the Judith River is in composition and appearance like the Pierre, but as it represents only a small part of that formation it is given another name (Bearpaw). The Lance formation is apparently continuous and regular throughout the section here described. 




$A$.



B.

VIEWS IN THE SHEEP RANGE OF MONTANA.

As shown in the upper view, the watchful herder and the equally vigilant sheep dogs guard the defenseless flock. The covered wagon shown in the lower view has been developed to meet the special needs of the sheep herder. It is light in weight and commodious and in bad weather affords protection from the fierce storms which sweep over the Montana plains 




A. POMPEYS PILLAR, MONT, AS SEEN FROM THE NORTHERN PACIFIC RAILWAY.

The inscription shown below is on the other side of the pillar.

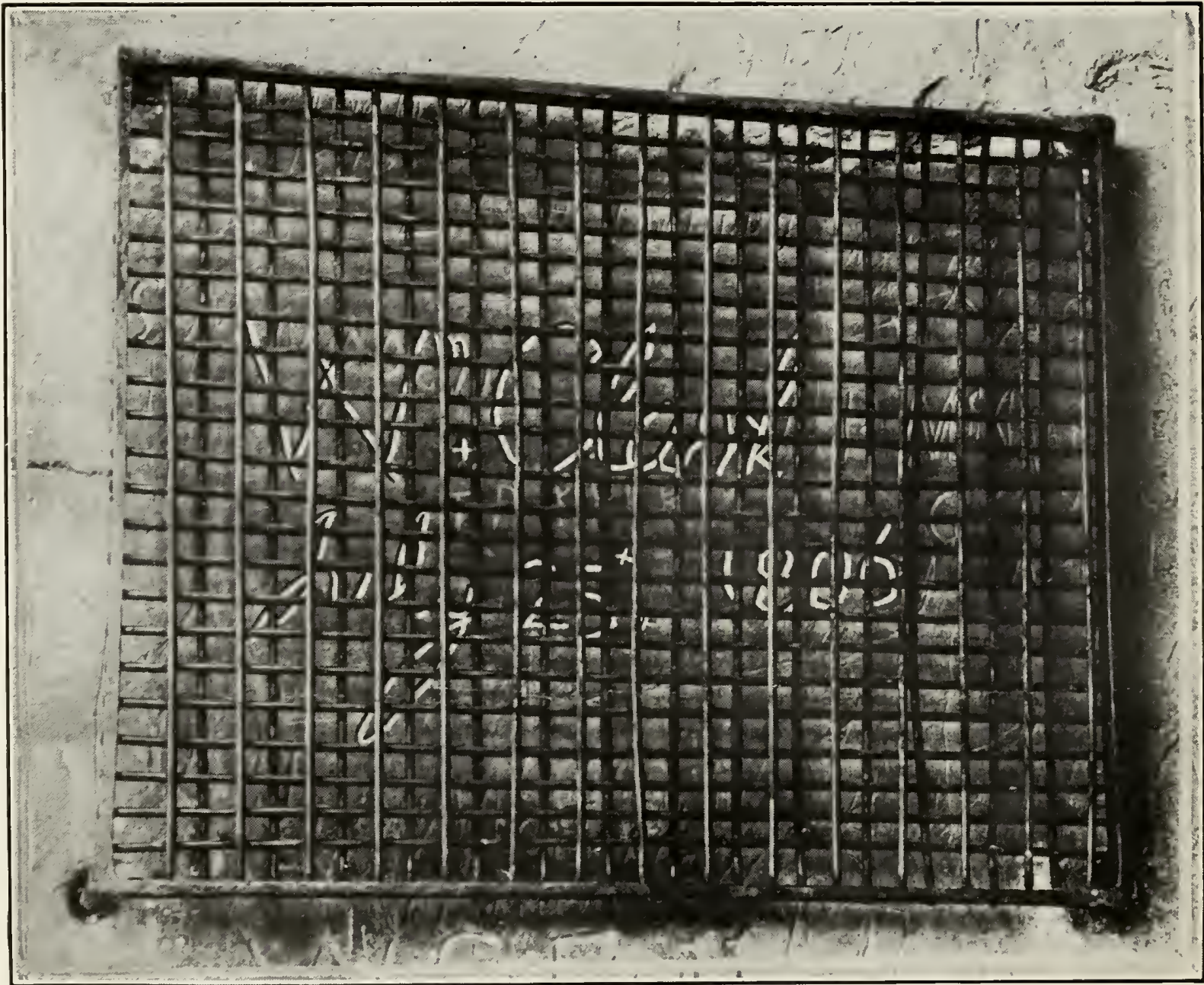

B. INSCRIPTION MADE BY CAPTAIN CLARK ON POMPEYS PILLAR JULY 25, 1806.

Now protected by an iron grating. Photograph furnished by the Northern Pacific Railway. 
carried by a gravity system down the valley for a distance of 30 miles. Part of this system has only recently been opened, so that all the land is not cultivated, but in the older parts fine crops are raised.

West of the sandstone outcrop the valley floor is again smooth, showing that the soft shale forms it as well as the low hills that appear far to the left (south). A little beyond

Sanders.

Elevation 2,618 feet. Population 281.* St. Paul 812 miles. Sanders the railway crosses Sarpy Creek, one of the well-known places of the early days, for here was located Fort Sarpy, an important trading post of the American Fur Co. and the headquarters of many of the hunters and trappers of the Northwest. The post was ramed for if not established by Col. Peter Sarpy, who was an agent of the fur company for 30 years after its organization.

At Hysham the valley is very wide, the hills being at least 2 miles back from

\section{Hysham.}

Elevation 2,667 feet. Population 162.* St. Paul 818 miles. the Lance formation coming in close to the track, and for several miles the road follows the river bank under a towering cliff that rises to a height of 300 feet.

The traveler is now in what was a few years ago the great open sheep range of Montana. Single ranches had flocks ranging from a few hundred to as many as 40,000 sheep. These were not kept in



Figure 10.-Monument built by sheep herder. a fenced inclosure as is done in the East but were herded in bands of a few hundred or a few thousand each. To each band was assigned one or two herders who with horses to draw a covered wagon and a faithful dog followed the sheep for months at a time without returning to the home ranch. (See Pl. XII.) Hour after hour, day after day, and week after week were spent in watching the sheep, with absolutely nothing to break the monotony of the rolling treeless plain except here and there low hills of barren rock. The herder would stand upon such eminences when the sheep were quietly feeding and no coyotes near to cause uneasiness and, to amuse himself, would build monuments of the loose rocks (fig. 10). In the course of time monuments of this kind were erected on almost every hill and on all the commanding points of the river bluffs, and the traveler can doubtless see them from the passing train. 
The dry-land farmer has gradually encroached upon the open range, and before long large flocks feeding upon it will be seen no more. Conditions will become more and more like those in the East, and finally the sheep herder, like his enemy the cowboy, will pass out of existence and will live only on the canvas of some Remington or Russell.

The next station is Bighorn, which is only a short distance east of Bighorn River. This is historic ground also, for it has been occupied almost continuously since it was first visited by Capt. Bighorn.

Elevation 2,712 feet. St. Paul 834 miles. Clark July 26, 1806 . In the year immediately following Clark's visit Manuel Lisa, one of the restless, adventurous spirits of the frontier, established a trading post here which afforded a rendezvous for many of the hunters of the region. In $1822 \mathrm{Col}$. William H. Ashley, president of the Rocky Mountain Fur Co., built a trading post 2 miles below the mouth of Bighorn River which he called Fort Van Buren. It was here also that Gen. Gibbon, in 1876, crossed the Yellowstone and proceeded overland with his detachment of 450 men to cooperate in the Battle of the Little Bighorn, which Custer had already lost.

A little beyond Bighorn station the train crosses Bighorn River and, skirting the base of sandstone bluffs for a distanca of 3 miles, plunges into the blackness of the Bighorn tunnel, to

\section{Custer.}

Elevation 2,749 feet. lopulation 335 .* St. Paul 839 miles. emerge at the town of Custer. 'This town derived its name from the fact that it was the stopping place for persons going to old Fort Custer, at the mouth of Little Bighorn River, but, despite the fact that the post has been abandoned, Custer retains its importance on account of its situation in the center of a fine agricultural district. Several years ago the skeleton of a Triceratops was found in the Lance formation which makes the river bluff opposite this place.

West of Custer the bluffs on both sides of the river are composed of sandstone of the Lance formation, but they are not so prominent as those below the mouth of Bighorn River. In places the low hills rise abruptly from the water's edge and the roadbed of the railway was made by blasting the solid rock. Generally, however, the hills are back half a mile or so from the track.

From Waco (see sheet 13, p. 82) to Bull Mountain the same kind of topography prevails, except that the bluffs on the north side of the river are more pronounced and rise abruptly

\section{Bull Mountain.}

Elevation 2,\$67 feet. St. Paul 856 miles. from the water level. Near Bull Mountain the hills on the south are farther from the track, lower, and less rugged than they are farther east. Such changes in the appearance of surface features are due to the presence of softer rocks. Here the formations are rising westward, and at Bull Mountain the Bearpaw shale, underlying the Lance formation, is again brought 

to the surface, but because of its softness it soon weathers down to a dark mud that so conceals the rock from which it was derived that the rock can not be seen from the train.

West of Bull Mountain the Northern Pacific Railway crosses the northern point of one of the great mountain-making folds of the Rocky Mountains. The rocky layers or formations have been forced up into a great arch which has a breadth, where crossed by the railway, of 75 miles and a length of about 180 miles. In the region of its greatest development in Wyoming it forms the Bighorn Mountains, and it is generally spoken of as the Bighorn uplift or anticline, but the northern projection into Montana has a local development in Pryor Mountain and for that reason is known as the Pryor Mountain anticline.

As the railway crosses the fold at its north end, where the formations swing around in broad curves, it cuts the outcrops at oblique angles or follows them for a considerable distance. It is because of this fact that the hills on the left are smooth and low, indicative of shale, and the bluffs on the opposite side of the river are rugged, being composed of sandstone.

One of the most striking mementos of the early exploration of the Yellowstone Valley is Pompeys Pillar (Pl. XIII, p. 77), a lone butte, 200 feet high, between mileposts 196 and 197. In descending the Yellowstone Capt. Clark noted this butte and from its isolated position and vertical walls called it Pompeys Pillar. He states concerning it, "I marked my name and the day of the month and year." Halfway up on the side near the river is to be seen Clark's rude inscription, now protected by an iron grating. The sandstone forming Pompeys Pillar is near the base of the Lance formation, and the westward rise of the rocks soon brings up the dark marine Bearpaw shale, but near the railway this shale is covered by soil and can not be seen from the train.

From Pompeys Pillar to Huntley the railway line is in the middle of a broad, flat bottom, which is irrigated by water taken from the river a short distance above the mouth of Pryor

Newton.

Elevation 2,915 feet. St. Paul 866 miles. Creek, under the Huntley project of the United States Reclamation Service. ${ }^{1}$ The underlying rocks are not visible from the train except at a great distance on the right. As shown on sheet 13 (p. 82), the first formation to be passed over beyond Pompeys Pillar is dark shale (Bearpaw) of

\footnotetext{
${ }^{1}$ The Huntley project covers an area of 33,000 acres in the broad valley of Yellowstone River. In 1907 this region was a part of the Crow Indian Reservation and was uninhabited. To-day it contains 400 farm families and six towns. The trans-

formation wrought by Government irrigation is apparent in the present compact, intensively cultivated farms, in substantial farm buildings, and in growing towns.

A few farms under this project are open to homestead entry under the terms of the
} 
marine origin. Next is a formation (Judith River) which in many places carries coal beds and was laid down on the land or in shallow lakes. It is soft and mostly light colored, but at a distance it can not be distinguished from the overlying Bearpaw shale.

At Huntley the Northern Pacific is joined by the Kansas City line of the Chicago, Burlington \& Quincy Railroad, and the two systems uso the same tracks from Huntley to Billings. Pryor

Huntley.

Elevation 3,038 feet. Population 1,746.* St. Paul 880 miles. Creek, which is crossed by the train soon after leaving Huntley, was named by Capt. Clark for one of his party. West of the creek the railway is at the foot of a precipitous bluff of greenish sandstone, in places thick bedded, which is the upper part of the Claggett formation. This underlies the Judith River formation and from the fossils that it contains is known to have been laid down in the sea. Thus, under the influence of the great Pryor Mountain anticline, lower and lower rocks are in turn brought to the surface. Beyond the bluff the sandstone rises until near milepost 220 it can be seen on the left (south) just capping the highest hills. The rock underlying the sandstone is not exposed here, but it is known to consist of soft shale, the lower part of the same formation. Where it is crossed by the line of the railway, the valley is broad and the slopes on either side are smooth and gentle.

West of the open part of the valley just described the hills close in on the river, especially from the south, until it seems as if the stream would be blocked, but on close approach it is apparent that the water has cut a narrow passage through what appears to be a barrier across its path. The railway is crowded close to the bank of the river, and west of milepost 223 hillside cuts show that the constriction of the valley is due to a thick bed of coarse sandstone (Eagle) which crosses the river nearly at right angles and dips $15^{\circ}$ or $20^{\circ}$ to the east. Immediately west of this outcrop the railway crosses Yellowstone River to the broad flat upon which the town of Billings is situated. As the train enters the yards just west of the river the Eagle sandstone can be seen on both sides of the valley.

reclamation act, and full particulars may be obtained at Huntley from the project manager. The cost of the water right is $\$ 45$ and $\$ 60$ an acre, payable in 20 annual installments without interest, and an additional charge of $\$ 4$ an acre, which is turned over to the Indians, is made for the land.

The climate is healthful and the soil fertile, producing abundant crops when watered. Cereals and alfalfa are the principal crops, but the growing of sugar beets is becoming profitable. There is a sugar factory at Billings, and more land has been put into beets each year.

Probably no section in the West has experienced the freedom from speculators enjoyed by the area under the Huntley project. As a result, this is to-day one of the most prosperous and up-to-date communities in the Northwest. Its progressive spirit is shown by its centralized graded schools, its churches, the steady substantial growth of its towns, and its clubs and cooperative organizations. 
On the south side it forms a prominent cliff and on the north it swings to the west and borders the valley with a precipitous wall.

Billings, a division terminal, is the most important city in the eastern half of the State. It was named in honor of Frederick Bil-

Billings.

Elevation 3,139 feet. Population 10,031. St. Paul 892 miles.

lings, one of the early presidents of the Northern Pacific Railway Co. For a long time it was the greatest wool-shipping point in the United States, if not in the world, but in recent years much of the wool from the north has been diverted by the St. Paul road and the dry-land farmers have taken up so much of the open range that the raising of sheep has been greatly reduced and is likely to become one of the vanishing industries of this region.

The earliest authentic record of exploration in the vicinity of Billings is that of Capt. Clark, who on his return from the Pacific coast passed the site of the city July 24, 1806. Soon afterward fur traders and trappers explored most of the streams of this country in search of beavers, and in so doing they frequently passed up and down the valley of the Yellowstone, but they left no record except possibly their names attached to some of the old trading posts or to the streams. The first permanent settlement in this vicinity appears to have been made about 1876, when a place called Coulson wạs established as a stage station and steamboat landing. Coulson continued to be of importance until the railway was built in 1881-82. In 1883 a street railway, the first in Montana, was built connecting this town with Billings, then recently established. The new town soon outgrew its rival, and to-day Coulson has disappeared.

Originally the valley outside of the lower land was clothed only with sagebrush, and for a number of years after the completion of the railway but little farming was done. As the annual rainfall is only about 14 inches and the summer season short it was thought that even the hardier grains could not be successfully raised here. About 1892 agricultural development started in earnest, ditches were dug, and water was taken to the land, and to-day there is no more fertile and productive valley in the State than that of the Yellowstone about Billings. Sugar beets are the principal crop, but alfalfa and grains are also grown in abundance. Farming is now the main occupation of the people about Billings. A large sugar factory has been erected at Billings which manufactures sugar from beets grown in many of the irrigated valleys in this part of the State.

Near milepost 3, west of Billings, the traveler may, if the day is clear, catch his first glimpse of the Rocky Mountains, directly ahead, nearly 100 miles away. In midsummer the outline of the mountains may be faint and scarcely discernible, but early in the summer or in the autumn the snow on their summits should cause them to stand $40063^{\circ}-$ Bull. $611-16-6$ 
out clear and distinct. If the traveler is fortunate enough to obtain such a view, he will understand why, in the early descriptions, they were always referred to as the "Shining Mountains." The mountains that can be seen from this point are the ranges that lie just south of Livingston and bound Yellowstone Park on the east.

At this point also the setting of the valley can be well seen. Billings has for a background a high bluff capped by massive šandstone or "rim rock" (Eagle). This can be followed to the east by the eye until it dips below water level and then reappears on the south side of the river in equal boldness and ruggedness, but instead of following parallel with the valley it strikes due south across country to Pryor Creek, the next stream in that direction. Its outcrop is everywhere marked by an escarpment, and at the last point at which it can be seen it makes an abrupt break in the sky line. On the right (north) the cliff trends nearly due west, as shown on the map (sheet 13), but the railway runs toward the southwest and consequently departs more and more from the cliff. 'The rim rock is visible as far as milepost 8 , but beyond that point it is obscured by the edge of the terrace on the right.

The traveler may notice that the river bluffs on the left (south) look very different from the rim rock. There are no ledges on these bluffs and they are composed of dark shale (Colorado shale), which underlies the rim rock. This shale is the lowest and oldest formation that has yet been seen on this trip west of Minnesota.

Near milepost 12 a branch of the Great Northern Railway which uses the tracks of the Northern Pacific from Billings to this place turns northward, going to Great Falls and Shelby, where it unites with the Great Northern main line.

From Laurel a branch of the Northern Pacific Railway leads to the south across the Yellowstone and up the valley of Clark Fork to the towns of Bridger and Red Lodge. Red Lodge is the

Laurel.

Elevation 3,311 foet Population 806.

St. Paul 908 miles. largest town in a coal field that supplies most of the fuel used by this railway in its mountain divisions from Butte and Helena on the west to Mandan on the east. ${ }^{1}$
${ }^{1}$ The Red Lodge coal field, at the foot of the Beartooth Mountains in Carbon County, supplies fuel for the railway, for the big smelter at Anaconda, and for a large domestic trade.

In quality the Red Lodge coal is distinctly below most of the eastern coals but compares favorably with many of the Rocky Mountain coals. It shows a tendency to slack on exposure to the weather and consequently is classed by the United
States Geological Survey as subbituminous, but this tendency is so slight that the coal evidently belongs at the top of its class, which is near the dividing line between the bituminous and subbituminous coals. Its heating value ranges from 10,570 to 11,440 British thermal units.

The field comprises only about 40 square miles, but the number and thickness of the coal beds compensate in some degree for the small area. According 


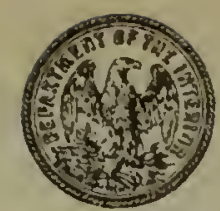

GEOLOGIC AND TOPOGRAPHIC MAP OF THE

\section{NORTHERN PACIFIC ROUTE}

From St. Paul, Minnesota, to Seattle, Washington

Base compiled from United States Geological Survey Atlas Sheets, from railroad alignments and profiles supplied by the Northern Pacife Rallway Company and trom additional

UNITED STATES GEOLOGICAL SURVEY GEORGE OTIS SMITU, DIRECTOR

David White, Chief Geologist $\quad$ R. B. Marshall, Chief Geographer

$$
1915
$$

Eash quadrangle shown on the map with a name in parenthesis in the





The traveler has now passed the axis of the great Pryor Mountain anticline, which brings to light the Colorado shale south of Billings, and the rocks dip gently and regularly toward the west. Under the influence of this westward dip the shale (Colorado) visible in the bluffs on the south side of the river soon passes below water level, and the cliffs of sandstone (Eagle) on the north begin to approach the railway. Near milepost 20 the cliff is about 2 miles distant and consists of three beds of sandstone with intervening shale or soft sandstone, as shown in figure 11. As the dip is

\section{Park City.}

Elevation 3,410 feet. Population 903.* St. Paul 915 miles. low, only about $10^{\circ}$, the Eagle sandstone approaches the river slowly, but at milepost 25 it can be seen in the hills on the south side of the river.



Figure 11.- Eagle sandstone north of Park City, Mont.

The top of the sandstone passes below water level at a siding called Youngs Point, beyond Park City (see sheet 14, p. 86), and here about 300 feet of shale and another sandstone inmediately overlying the Eagle are visible across the river. These beds make up the lower part of the Claggett formation, which dips gently westward and gradually disappears beneath water level. At milepost 32 all the white sandstone has passed from view and the hill slopes are comprised of the overlying Judith River formation. This formation has no decided

to a section measured in the bluffs on the east side of Rock Creek in and below the town of Red Iodge and in the mine workings there is 90 feet of coal in beds 3 feet or more in thickness. The beds vary greatly in size, being thicker near Red Lodge than in any other part of the field so far explored, but the quality is somewhat better about Bear Creek, in the eastern part.

These coal beds (in the Fort Union formation) are made up of the same sort of vegetation as the great lignite beds of North Dakota, but being nearer to the mountains the coal is of much better quality, for the reason given on page 71 . The coal beds dip from $10^{\circ}$ to $20^{\circ}$ toward the southwest, or into the mountain, which is separated from the coal field by an immense fault.

Although mining at Red Lodge was begun before 1882, it was conducted on a small scale until 1889 , when railway connection was established and some large mines opened. Since then the field has been developed steadily until now it is first in point of production in the State. The coal production of Carbon County, which includes the Red Lorlge field, in 1913 amounted to 1,304,524 short tons.

It is estimated that the amount of coal in the Red Lodge field before mining began was $1,691,800,000$ short tons. If from this is deducted 12,544,796 short tons, the total amount mined to the end of 1913 (the latest statistics yet compiled), and about $4,000,000$ tons that was rendered unavailable through mining operations, there would still remain about $1,675,000,000$ short tons. Not all of this can be regarded as minable, for in mining some coal is almost always left in the ground or rendered unavailable on account of breaking down of the roof. According to present practice only from 60 to 80 per cent of the coal in the ground is mined, but as methods improve more and more of the coal will become available. 
characteristics by which it may be recognized and identified, but it contains fewer beds of sandstone, and consequently makes smoother hill slopes than the underlying Claggett formation. 'The slopes composed of the Judith River formation have a whitish-gray tint and are rather monotonous in color and appearance. The rocks composing the upper part of this formation are well exposed in Countrymans Bluff, between mileposts 37 and 38 . Here the rocks are undoubtedly of fresh-water origin, as they contain numerous fragments of fossil plants such as could have been deposited only either on land or in bodies of fresh water.

The continued westward dip of the rocks brings the next higher formation (Bearpaw shale) to water level in the vicinity of Columbus.

It can not be seen near the railway, but is well exposed

Columbus.

Elevation 3,624 feet. Population 521.

St. Paul 933 miles. a mile north of the town. This shale crops out in the valley of Keyser Creek north of the railway and along the foot of the ridge that begins just across the river from Columbus and extends southeastward as far as

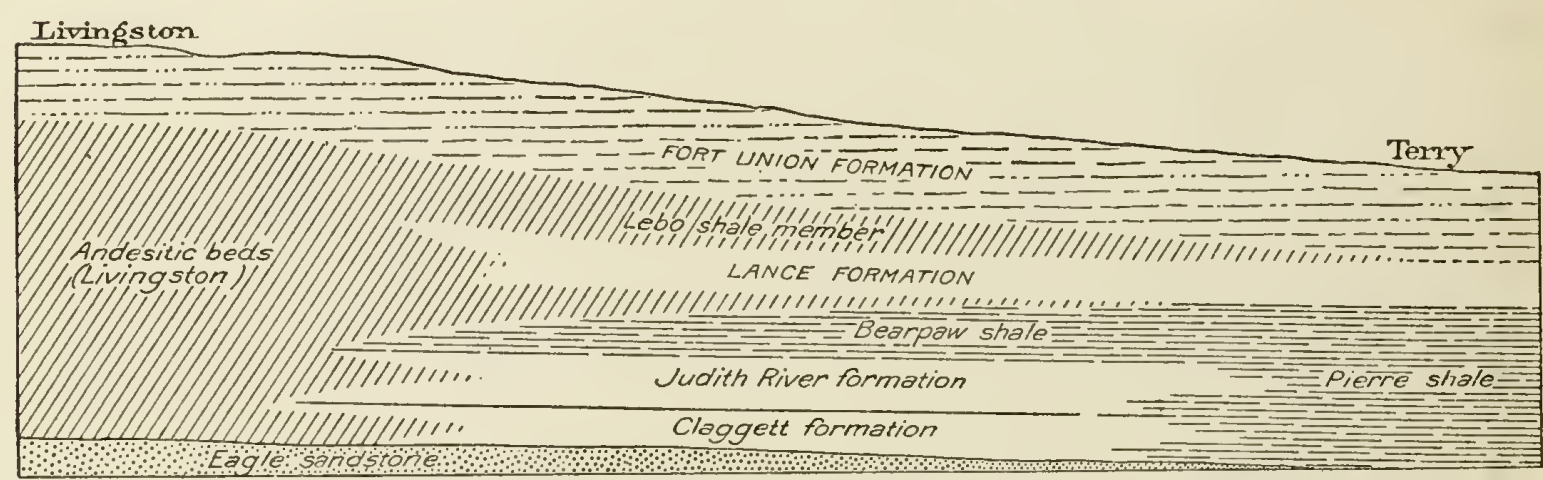

FIGURE 12,-Cross section to illustrate the change in the formations between Terry and Livingston, Mont.

the eye can see. This ridge is composed of beds of light-colored sandstone (Lance formation) which are almost identical with those seen in the vicinity of Hysham. In one of these beds a large quarry has been opened a mile north of Columbus, which furnishes a building stone of great excellence. This stone has been used in the construction of buildings in the neighboring towns and in the State capitol at Helena.

These sandstones cap Bensons Bluff, $2 \frac{1}{2}$ miles west of Columbus, and come down to water level near milepost 43 . The dips here are $6^{\circ}$ to $8^{\circ}$ to the west, but they flatten within a short distance and the rocks are practically horizontal.

The traveler may remember that at Terry he saw a wedge of somber-colored shale and sandstone immediately overlying the Lance and that the dark color of this wedge is due to the presence of volcanic material, which was washed far to the east from its place of origin somewhere near the Yellowstone Park. The relation of this wedge of volcanic material to the adjacent formations is shown in figure 12 . 
The train is now approaching the place of origin of this material. The gray sandstone of the Lance forms most of the slopes at milepost 50 , just beyond Merrill, and about 300 feet above the river the hills have a brownish appearance which indicates that some other formation makes their upper slopes. After crossing the river the same relations may be observed, except that as the train moves westward the brown Lebo shale can be seen at lower and lower levels, owing to the slight westward dip of the rocks.

At Reed Point the white beds of the Lance extend up the slopes only 100 to 150 feet, and above that all the rocks are brown. The

\section{Reed Point.}

Elevation 3,762 feet. St. Paul 950 miles.
Lance probably goes under river level near milepost 60 , and beyond that point the hillsides are much smoother and the general tone of the rocks is brown, indicating that the Lebo shale forms the hills at least for a height of 800 or 1,000 feet.

About three-fourths of a mile beyond milepost 63 a large dike, visible on the right (north), cuts directly through the bedded rocks in a direction nearly parallel with the railway. The dike is composed of a dark igneous rock which was injected in a melted condition into an extensive crack in the bedded rocks. It stands up like a wall, and where it cuts across a bed of light-colored sandstone it is easily recognized.

As the train rounds the curve at milepost 66 , the traveler looking forward and to the right can get his first good view of the Crazy Mountains (originally called Crazy Woman Mountains). This mountain group stands by itself in the plains and contains the first high peaks which the traveler can see at close range. Its mode of origin is described in the footnote beginning on page 86 .

East of this place the volcanic material of the Lebo shale has been so thoroughly washed and sorted by water that it is evenly bedded like ordinary shale and friable sandstone, but near the mountains and the source of supply this material is coarser and some of it has the appearance of being only a little modified by water after it was blown out of some old volcanic vent in the vicinity. Such material, known as volcanic agglomerate, is composed of fragments of lava ranging from minute pieces to blocks 4 feet in diameter. The agglomerate beds have in general a warm gray tint, and a mass of such material gave the name of Greycliff to a siding that was formerly located under the cliff but now has been moved 3 miles to the west. The cliff is fully 100 feet high, but the base of the agglomerate is not exposed and hence its full thickness may greatly exceed that amount. As it is reported to be 2,000 feet thick a few miles to the southwest, it seems reasonably certain that the old volcano which furnished the material was located in that direction, but no trace of it has been discovered. 
At Greycliff an upland stretching far to the north is visible across the river on the right. This is underlain by light-colored sandstones

\section{Greycliff.}

Elevation 3,940 feet. St. Paul 963 miles.

of the Fort Union formation, which show here and there, giving to the surface a light-gray appearance. As these rocks dip slightly westward, they should appear near railway level east of Big Timber, but no such rocks occur near the track. This is due to the fact that on approaching Yellowstone Park more and more of the volcanic material is present in the sandstones, giving to them a dark color that makes them indistinguishable from the underlying Lebo. ${ }^{1}$

After passing Big Timber the traveler obtains on the right (north) his best view of the Crazy Mountains, ${ }^{2}$ an isolated

Big Timber.

Elevation 4,095 feet. Population 1,022 . St. Paul 974 miles. group of sawtoothed peaks which rise sharply to a height of 6,000 feet above the generally even surface of the plain and 7,000 feet above the level of the railway.

Springdale (see sheet 15, p. 98) is the stopping place for those going to Hunters Hot Springs, which are visible on the right at a distance of about $1 \frac{1}{2}$ miles. These springs are reported to have Springdale.

Elevation 4,234 feet. St. Paul 989 miles. been well known to the Indians before the advent of the white man. They were discovered in 1864 by Dr. J. A. Hunter, who, with his family, was on his way to the newly discovered gold fields of Montana. The springs

1 The change in character of the materials composing the Fort Union may not be apparent from the train, but north of the Crazy Mountains, on Musselshell River, all the formations from the Colorado shale (the shale that is exposed across the river from Billings) to the Fort Union change toward the west to an andesitic mass in which formations are not distinguishable. This mass is generally known as the Livingston formation, and when it was named it was supposed to be younger than any formation so far described and to rest unconformably on all the older formations up to and including the Fort Union. This idea was based on its supposed relation to the other formations about Livingston and to the fact that the fossil plants which it carries are different from those in the Fort Union and also in the underlying formations. The anomalous character of the fossil flora has not yet been explained, but the apparent merging of the formations into one great mass of andesitic material toward the west is so apparent that it is now generally regarded as established that the Livingston is not a separate formation, but a peculiar near-shore phase of the other formations, produced by a great supply of volcanic material from an upland on the south.

2 The Crazy Mountains can not in any sense be considered as a range, for in form they are merely a group of peaks and in structure they are unlike any other range in this part of the country. The highest point, Crazy Peak, has an altitude of 11,178 feet, or about 6,000 feet above the general level of the plateau or bench land at its foot. The Crazy Mountains are therefore higher than many of the more noted mountains of Montana, and they are certainly more conspicuous on account of their compactness and isolation.

Structurally they have no relation to the ranges of the Rocky Mountains, for those ranges in general are formed of upturned or faulted strata, whereas the Crazy Mountains are merely the remains of a great irregular mass, called a stock, 
SHEET No. 14



GEOLOGIC AND TOOPOGRAPHIC MAP OF THE

NORTHERN PACIFIC ROUTE

From St. Paul, Minnesota, to Seattle, Washington

Base compiled from United States Geological Survey Atlas Sheets, from railroad alignments and profiles supplied by Co this company

UNITED STATES GEOLOGICAL SURVEY GEORGE OTIS SMITH. DIRECTOR

David White, Chief Geologist $\quad$ R. B. Marshall, Chief Gengrapher 1915

Each quadrangle shown on the map with a name in paronthesis in the lower lift corner is masped in detail on the U. S. Q. S. Topographic
Sheet of that name

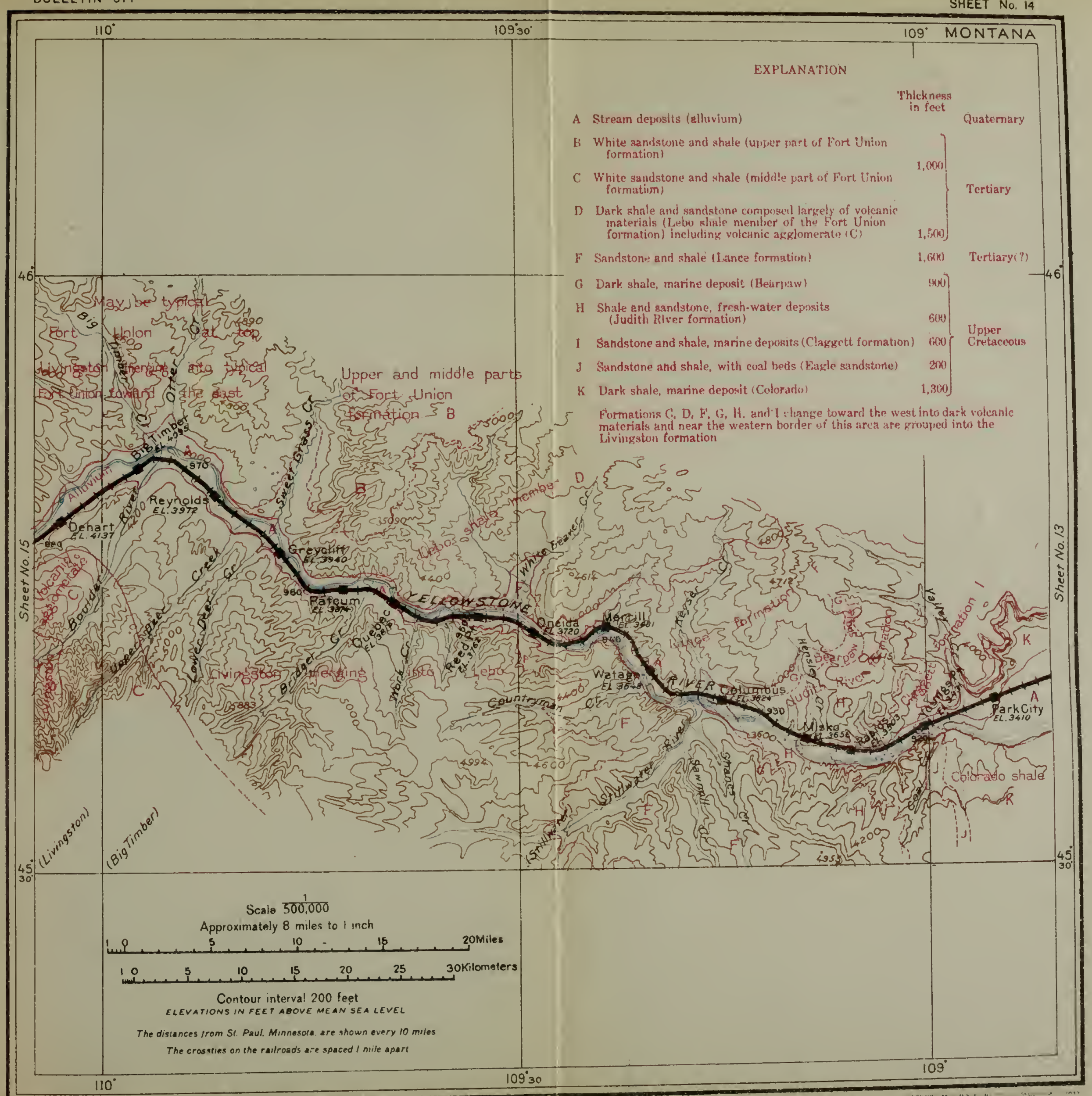



discharge 90,000 gallons of water an hour at a temperature of $148^{\circ}$ to $168^{\circ} \mathrm{F}$.

Beyond Springdale the river passes through a narrow gorge known as McAdows Canyon. In this canyon the rocks, which are well exposed, show many wrinkles or minor folds that were undoubtedly formed by the upheaval of the great Absaroka Range, on the south. The mountain range is high and rugged, indicating a youthful stage in its development, for if the range were old it would have been worn down by erosion and its rugged features would have been smoothed and rounded off. Another proof that the Absaroka Range has been recently formed is found in the fact that the rocks along its flanks have been wrinkled and upturned by the same forces as those that folded and raised the mountain rocks into their present positions. From this it is evident that the mountains must have been formed since the deposition of the youngest of the plains rocks, and as the Fort Union formation, which is early Tertiary, is involved in the folding, the mountains must have been formed in middle or late Tertiary time.

On the right (north) near milepost 103 a near-by view may be obtained of the Sheep Cliffs, which, as seen from the train, are very prominent. They are the result of an intrusion of molten lava between beds of sedimentary rocks, probably from some of the dikes

of igneous rock that was forced in molten condition into the soft shale and sandstone of the upper Mesozoic and lower Tertiary formation. At the time this great mass of igneous material pushed into the soft sedimentary beds, the surface must have been above the present top of the mountains. J. P. Iddings, who has given the most study to this mountain mass, says that it is not at all certain that the molten material ever poured over or even reached the surface. It is exposed to view now because the beds that once covered it have gradually been washed away by rain and streams.

The stock is 4 miles wide and 6 miles long. It consists of a very coarse grained diorite which disintegrates rapidly when exposed to the weather. In this condition it is easily eroded, and the slopes are very steep, as can be seen from the train. The present mountains are made up not only of the igneous rock, but also of the shale and sandstone into which it was forced. These rocks were heated so intensely that the shale has been baked into a porcelain-like mass that is very hard and resists weathering much more successfully than the diorite. These baked rocks form a zone nearly a mile wide around the core. Through this zone and beyond it the rocks have been cut and hardened by a countless number of dikes that radiate from the central mass in all directions. Here and there the molten matter has found an outlet between the beds of sandstone, resulting in great sheets or sills of the hardened lava. These are very dense and serve as protecting caps to the softer strata beneath. -The forcing of so much material between the layers of the sedimentary rocks has raised them up around the stock until they dip from it in all directions.

Nearly the last stage in the evolution of this group of mountains is the sculpturing they have received from local glaciers during the Great Ice Age. These were so small that they did not even coalesce and form an ice cap, but each little glacier scoured out the valley in which it lay and built a moraine at its cuter end, where it came down nearly to the level of the bench land. 
connected with the core of the Crazy Mountains. When this sheet of igneous material was forced in between the beds they were in all probability deep in the earth, but the cutting of the streams has revealed the igneous rock, and owing to its superior hardness it stands up almost like a mountain.

West of milepost 105 a glimpse can be obtained on the right, ahead, of the highest part of the Bridger Range, which, though small, has a very sharp crest and which separates the valley of the Yellowstone from the headwaters of Missouri River on the west. The structure and character of this range are illustrated by figure 17 (p. 98).

At Mission station a branch leaves the main line and after crossing Yellowstone River follows up Shields River, so named by Capt. Clark for a member of his party. This valley has the reputation of producing some of the finest oats grown in the State.

Just before the train enters Livingston it crosses Yellowstone River for the last time on the main line. Here the Yellowstone is a clear, rushing mountain stream, very different from the turbid river farther east. The traveler now comes face to face with the great mountain wall that forms the north front of the Absarokas and can look up at the commanding heights, which tower nearly a mile above him and which during much of the year are covered with snow.

Livingston, originally called Clarks City, was named in honor of Charles Livingston, of New York, one of the directors of the Northern Pacific Railway. The main line of the road was fin-

\section{Livingston.}

Elevation 4,510 feet. Population 5,359. St. Paul 1,008 miles. ished to this place on January 15, 1883, and the branch line to Yellowstone Park, which now carries many thousands of tourists annually, began operation in August of the same year. Livingston is a division terminal and essentially a railway town.

\section{LIVINGSTON TO GARDINER (YELLOWSTONE NATIONAL PARK).}

The train for Yellowstone Park, on leaving Livingston, turns to the left (south) and heads directly for the mountains, through a wide bottom which, though composed largely of gravel brought down by the river, is mostly under a high state of cultivation. For some distance the rocks are not well exposed, as the railway is built on alluvial material (material laid down by running water) and the rocks can be seen only in the cut edge of a low terrace on the right (west). The formations are upturned against the mountains at an angle of about $20^{\circ}$, and as the railway runs at right angles to their upturned edges the train passes them in quick succession. 
The main outer range which forms the gateway through which the train enters the mountains is composed of very old (Paleozoic) rocks, chiefly limestone, shale, and quartzite. ${ }^{1}$

The great mountain mass beyond this outer range is anticlinal in structure; that is, it once formed an immense arch. The top of the arch is eroded and the traveler can not see the formations rising on one side of the fold, curving over the top, and descending on the other side, but they once formed such an arch, and the flanks and

1 The smooth slopes of the terrace on the west are composed of the Eagle sandstone, which is not well exposed and probably not recognizable from the train, and the underlying dark shale of the Colorado, which is well exposed south of Billings. The relation of the various beds can be better understood by consulting figure 13, which shows the rocks as the traveler sees them on the right. Opposite milepost 3 are sandstone and red shale, which underlie the dark shale of the Colorado. These beds constitute one of the most re-
The next formation to attract attention consists of a great mass of limestone, which makes the mountain front and which is one of the most conspicuous sedimentary formations in the Rocky Mountain region. It will be seen many times on the trip and the traveler will doubtless learn to recognize it wherever seen. This thick-bedded formation is of early Carboniferous age and is known as the Madison limestone. It makes the front of the mountain on the east side of the river as far as the eye can see and on the west side for a distance of



FIGURE 13.-Cross section showing the rim of the mountains south of Livingston, Mont. The rocks were crowded together until they bent into great folds, which later broke, resulting in overthrust faults.

sistant formations of the plains and on the east si de of the river they make a hogback ridg thich is a fine example of its kind. This formation was at one time regarded as the Dakota sandstone, but is now known to be the Kootenai, of Lower Cretaceous age. It is the same formation as that carrying the coal beds at Sand Coulee and Belt, southeast of Great Falls, but in the vicinity of Livingston no coal has yet been found in it. Below the Kootenai there are shale and limestone containing fossil sea shells of Jurassic age.
7 or 8 miles. Its base can be seen about $4 \frac{3}{4}$ miles south of Livingston, or just opposite the county bridge across the river. Beneath the Madison is a great mass of shale, limestone, and quartzite embracing formations of Devonian, Silurian, and Cambrian age, but as these various formations can not be distinguished from the train they will not be described in detail. Some of these are very old rocks, even older than the St. Peter sandstone, which was seen at St. Paul. 
core of it still remain to tell the story to the geologist. There are on the flanks of the large fold a number of small folds, and the rocks that have just been described constitute such a wrinkle. This minor fold, as shown in the section (fig. 13), has been pushed over toward the south beyond the vertical, so that the beds on the south side dip toward the anticline instead of away from it, as they would had they not been overturned. This fold is bounded on the south

\section{Brisbin.}

Elevation, 4,717 feet. St. Paul 1,018 miles.

by a fault (a break in the rocks), and near Brisbin it is succeeded by a smaller fold of the same type. The Madison limestone making the core of this smaller fold forms the high, straight ridge or spur that trends at right angles to the railway. Beyond this ridge there are traces of another kind of fold-a trough or syncline which lies at the base of the limestone ridge and extends far to the northwest where it contains the Trail Creek coal field. Coal is being mined from Cretaceous rocks in this syncline at the present time, but the product of the mines reaches the railway on the other side of Bozeman Pass.

Beyond Brisbin the rocks on the west forming the Gallatin Range are made up of volcanic materials, some of which consist of fine fragment (tuffs) blown out of some crater with explosive violence or of coarse angular blocks derived from the same source or from the breaking up of partly cooled lava flows.

The rocks on the east side of the valley from Deep Creek, opposite Brisbin, on the north to Mill Creek on the south are very ancient gneiss and schist. This great mass of crystalline rock constitutes the central part of the large anticline already described, from which all the younger sedimentary formations have been removed by erosion. Traces of the sandstones and limestones that once constituted the south flank of the fold are to be found up Mill Creek, but they are so badly faulted and covered with volcanic breccia (rock composed of angular fragments) that they can not be easily recognized from the train. The most prominent peak in this part of the valley is Mount Cowen, which has an altitude of 11,190 feet and stands 6,400 feet above the bottom of the valley.

As far as milepost 16 the railway is on the flat surface of a terrace 50 to 75 feet above river level. This was formed by the glaciers that, long ago, came down Yellowstone and Mill Creek

\section{Chicory.}

Elevation 4,872 feet. St. Paul 1,028 miles. valleys and joined near the village of Chicory. The streams flowing from the melting ice carried large quantities of gravel and sand and dropped them in the open valley, filling it to a considerable depth. Since the ice melted away the river has cut a deep channel in this filling, leaving remnants of it here and there in the form of terraces. As the terrace was built only below the limit of the glacier, the railway is forced, 


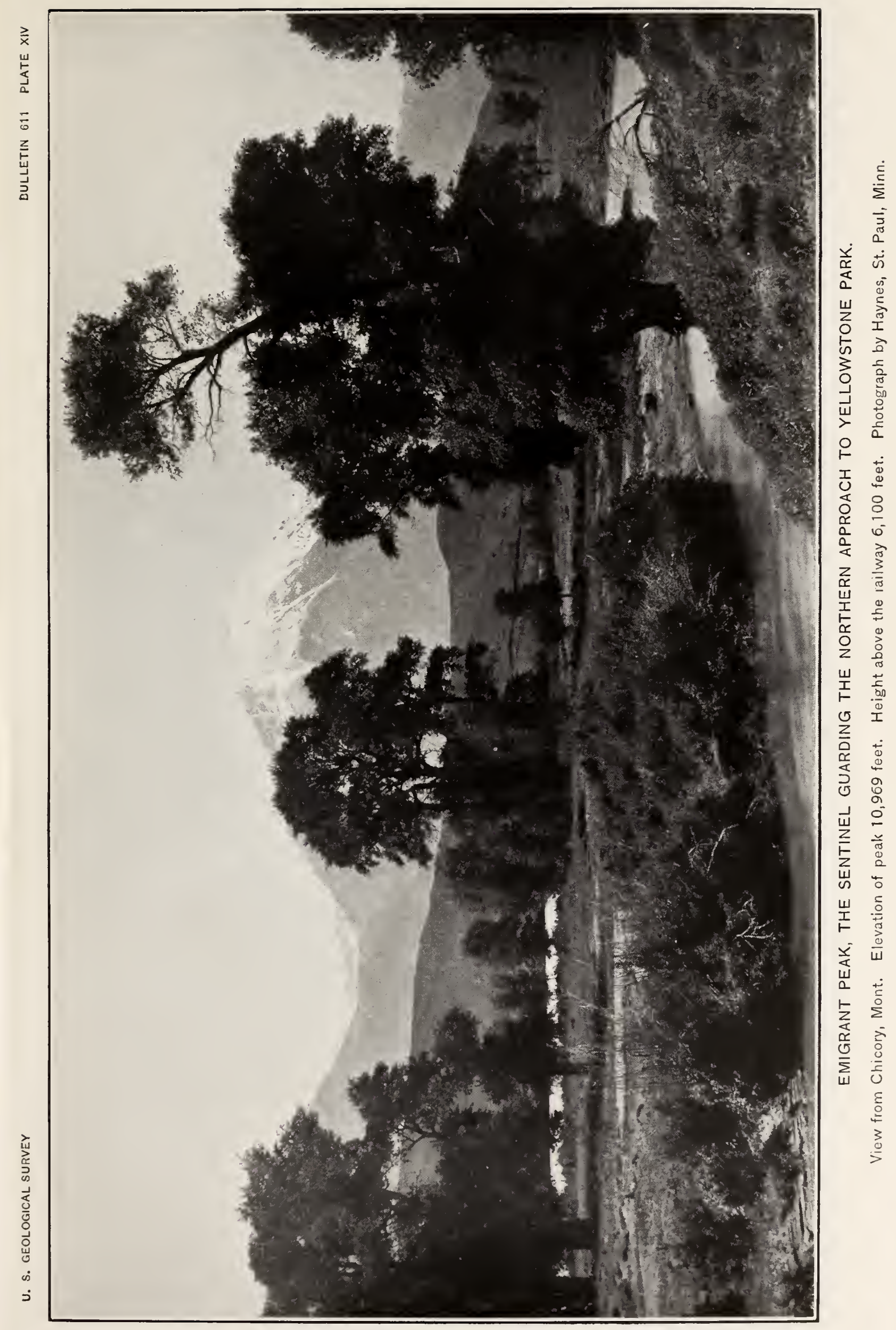







opposite the mouth of Mill Creek, to leave the terrace and descend to the valley bottom on which lay the great mass of ice.

In the vicinity of Emigrant there is a thin sheet of basalt (a dark massive volcanic rock) capping the terrace on the right. This rock exhibits the vertical columnar structure common to

\section{Emigrant.}

Elevation 4,887 feet. St. Paul 1,031 miles. such material, and it is probable that the several masses of basalt which can be seen up the canyon are parts of one lava flow that originated somewhere in the park and extended down the valley as far as this place. It can be followed on the right for 3 miles, but beyond that it has been eroded for some distance, leaving no trace of its presence.

In the vicinity of Emigrant the most prominent topographic feature is Emigrant Peak (Pl. XIV), which dominates the entire valley. From the train this appears to be an isolated mountain, but the map shows that it is merely a prominent spur projecting from the mountain mass. The peak has an altitude of 10,960 feet, and its summit stands 6,000 feet above the valley. The base of the peak is composed of old gneiss, a rock which the traveler will have a good chance to see at close range farther up the canyon, and its summit of the andesitic breccia and lava flows that at one time probably almost engulfed the range on the east and completely submerged that on the west. At milepost 24 the high, sharp summits of the Gallatin Range show on the right (west), but they are neither so rugged nor so imposing as the peaks on the east.

The sheet of basalt capping the terrace on the right in the vicinity of Emigrant disappears for a mile or more, but opposite milepost 28 it reappears on the other side of the river, capping a finely developed terrace at a height of about 150 feet above the river.

At Daileys, a little farther on, a complete section of the rocks forming the terrace can be seen, and these rocks record an entirely

Daileys.

Elevation 4,941 feet. St. Paul 1,039 miles. new chapter in the geologic history of this region. They consist of white marl and conglomerate overlain by dark gravel and the whole covered with the sheet of basalt that was poured out upon the surface as molten lava. The white materials are known, from their composition and the fossils they contain, to have been deposited in a lake or lakes in Miocene or Pliocene time. A brief description of these lake beds is given on page 113 .

The sheet of basalt capping the terrace can be followed as far as milepost 33, but from that point nearly to the entrance to the park the terrace and the basalt are not present. At Point of Rocks, only a short distance farther on, the traveler can obtain a good idea of the kind of material composing a volcanic breccia, for the railway cuts through a projecting point of the breccia and it can be seen at close 
range. Here it is tinted a deep, rich red, which adds a warmth and beauty to the otherwise somber mountain slope.

At Miner the river valley makes an abrupt bend to the southeast and the rocks on the right show clearly the smoothing action of the Miner.

Elevation 5,021 feet. St. Paul 1,045 miles. glacier that once passed over them. Each projecting mass of rock has been rounded and smoothed, especially on the upriver side, which the glacier struck first in its course down the valley.

A short distance above Miner the stream passes through a narrow rugged canyon, the walls of which are composed of gneiss and show clearly the intricate folds into which this rock has been bent and the character of the different layers composing it. Through most of this canyon the tracks are on the very brink of the river channel, and the traveler can look down on the left in to the boiling flood which dashes and foams about the bowlders that have fallen into it from the rocky slopes above. The grade through this canyon is very steep, but the gorge is short and the slope of the valley beyond is more gentle.

At Corwin Springs is a hotel for the accommodation of those who wish to use the hot waters. Above this place Cinnabar Mountain, on the west, is the most conspicuous object, Corwin Springs. but the wonderful structure of the mountain and Elevation 5,133 feet. its peculiar appearance can not be fully appreciated St. Paul 1,055 miles.

until the traveler reaches Electric. Cinnabar Mountain was named in the early days, when the bright-red streak that marks it from top to bottom was supposed to be due to the mineral cinnabar, a red ore of mercury. It is now known that this red streak, called the Devil's Slide, is a bed of shale and that there is no cinnabar in the mountain. Almost the entire geologic column of this part of Montana is here exposed, and the rocks are turned up on edge so that they can be studied without the exertion of making a difficult climb. The oldest rocks are seen first, as one ascends the valley, and then others come in orderly succession, ranging from Cambrian to Upper Cretaceous. ${ }^{1}$

\footnotetext{
${ }^{1}$ The geologic section exposed at Electric, if placed in its correct position, would be as follows:

Feet.

Montana formation (Upper Cretaceous)..................... 955

Colorado shale (Upper Cretaceous) . . . . . . . . . . . . . . . . 2, 2,775

Kootenai formation (Lower Cretaceous)................ 577

Morrison formation (Jurassic or Cretaceous).................. 185

Ellis formation (Jurassic)............................. 277

Quadrant formation (Carboniferous) .................... 200

Madison limestone (Carboniferous) ...................... 1, 500

Threeforks shale (Devonian).......................... 240

Jefferson limestone (Devonian)..................... 200

Cambrian............................................ 700 
The town of Electric was established and extensive coal mines were opened at this place a number of years ago by the Montana Coal $\&$ Coke Co. Some of the mines were opened Electric. directly back of the town and some near the town Elevation 5.185 feet. but on the other side of the mountain, and the St. Paul 1,057 miles. coal was brought to the tipple by an aerial tramway. The coal is of excellent quality, apparently having been improved by the heat of igneous intrusions or by the intense pressures developed when the rocks were thrown into the great folds that are so apparent to-day, but the cost and difficulties of mining caused the undertaking to be abandoned. ${ }^{1}$

At Electric station Electric Peak (elevation 11,000 feet), one of the highest mountains in the vicinity, may be seen on the right. The peak was so named because of a severe electric storm during its ascent by members of the Hayden Survey in 1872. One of the men was severely shocked, and all the others experienced prickly sensations as if they were receiving the discharge from an electric machine. The station and coal field took their names from the mountain.

1 The coal beds in this field are probably the same as those mined in the Trail Creek field and at Bridger, near Red Lodge, and formerly mined extensively at Cokedale, west of Livingston, but the coal of the Electric field is probably the best in Montana. 'The coal beds occur near the base of the Montana formation, probably in the Eagle sand- sills of igneous rocks as to be scarcely identifiable. As shown by the map (sheet 15) and the section (fig. 14), the rocks are nearly flat in the southern part of the block, but are sharply upturned at the north end, forming Cinnabar Mountain. The great block of strata constituting the coal field is bounded on all sides by faults, and within this block

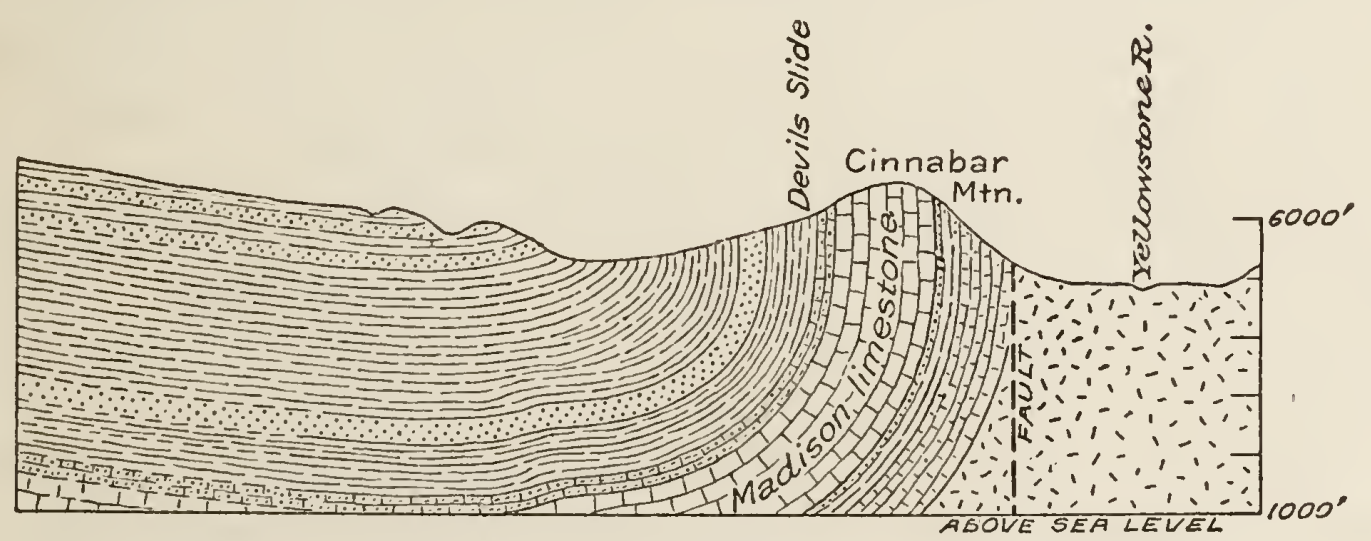

FigURE 14.-Diagram showing the structure of Cinnabar Mountain, Mont.

stone. The coal field consists of a great block of the earth's crust, containing not only the Cretaceous coal-bearing rocks but also all the older formations known in the region. This block of strata extends from Cinnabar Mountain (Yellowstone River) on the north to Electric Peak on the south, but in the south end the formation is so altered by dikes and another and small block has been broken from the larger mass and dropped about 1,000 feet. The smaller block contains the coal mine directly back of the town of Electric. Practicaliy all the coal mined in this field was coked, the market being chiefly the smelters at Butte and Anaconda. The heating value of the coal is 12,270 British thermal units. 
Above Electric bowlders of dark basalt and the outcropping edge of a sheet of similar material on the far side of the river indicate that a stream of basaltic lava once flowed down the river valley at least as far as Emigrant. Since it solidified the river has cut most of it away, leaving the two or three remnants noted.

At Gardiner the traveler has arrived at the northern entrance to Yellowstone Park. Descriptions of the park and the

\section{Gardiner.}

Elevation 5,287 feet. Population 346.\% St. Paul 1,062 miles.

of the western United States, Part B). principal routes through it are given in other Government and private publications. The railroad route to Yellowstone, Mont., the western entrance to the park, is described in Survey Bulletin 612 (Guidebook MAIN LINE WEST OF LIVINGSTON.

As the train leaves Livingston for the continuation of the westward journey, an excellent view can be obtained on the south of the entrance to the valley of the upper Yellowstone, sometimes called the "gate of the mountains." West of Livingston the railway crosses the northern point of the Gallatin Range at Bozeman Pass. This pass was discovered by Capt. Clark, who crossed the summit on his return journey July 15, 1806. He expressed surprise at the ease with which he passed from the Gallatin Valley on the west to that of the Yellowstone on the east. Although this is a low summit and an easy one to cross with a wagon or on foot, it offered a considerable obstacle to the railway, as it involved a climb from Livingston of 996 feet in 12.2 miles. Originally the railway followed the creek with an easy grade nearly to its head and then reached the summit by a very stéep ascent, but a few years ago a new roadbed having a regular grade from Livingston to the summit at Muir was established.

The mountain side on the left (south) presents many interesting features, especially to one not familiar with mountains. Early in the summer light-green grassy slopes interspersed with patches of brush or groves of aspen extend partway up the mountain to the forest of evergreen trees that thrives upon the upper slopes. At the lower margin of the forest the trees appear singly or in groups, but higher up they cover the entire surface with their dense foliage. Here and there are the marks of old burns in which the tree trunks stand out as whitened skeletons that later fall headlong in a hopeless tangle and then are concealed by the second growth of trees. Late in the summer the lower slopes may be brown, but with the coming of the early frosts the woods are bright with color, the soft yellow of the aspens blending with the reds and browns of the scrub maple and the oak. The lower limit of the timber, which seems to be fairly definite, is not 
controlled directly by the altitude but by the greater precipitation on the mountain slopes than on the plains below them.

Along the new grade many exposures of the Livingston formation can be seen in the deep cuts. It consists of chocolate-colored shale and sandstone of a lighter shade but still showing a brownish tinge, which is due to the fragments of volcanic matter of which it is composed. The beds are somewhat wrinkled and disturbed but generally dip to the right, away from the mountain, at an angle of about $20^{\circ} .{ }^{1}$

About half a mile beyond milepost 121, in a deep cut, two dikes of igneous rock are exposed cutting directly across the bedded sandstone and shale. In places where such dikes have cut through coal beds, or have taken the form of a sheet or sill below the coal, as illustrated in figure 15, the heat of the molten rock has changed the coal, the resultant material deponding upon the conditions attending

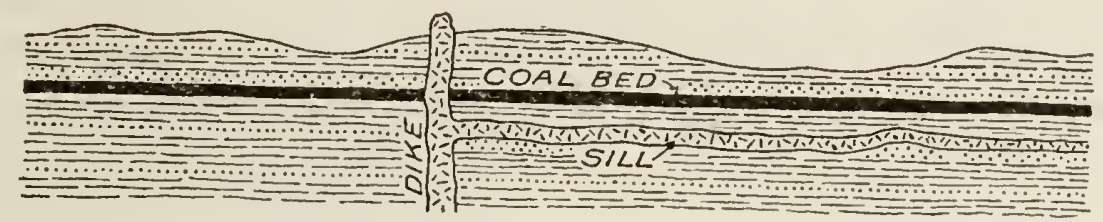

FIGURE 15.-Dike cutting coal bed and sill intruded in a position to affect the quality of the coal.

the intrusion. If air is present, the coal will burn out completely; if only a moderate amount of air is available, natural coke will be formed; and if little or no air is present, the coal will be baked into anthracite. Anthracite produced in this manner occurs in Colorado, New Mexico, and Washington.

After a long climb the summit is reached at Muir, a station at the east end of the Bozeman tunnel, which has a length of 3,610 feet.

\section{Muir.}

Flevation 5,506 feet. St. Paul 1,020 miles. The summit of the pass is only a few hundred feet above the level of the railway. Beyond the tumnel the Eagle sandstone, which was seen back of Billings and again obscurely at Livingston, carries coal beds which have been prospected and mined at various places west of Livingston. As a general rule the coal crops out along the base of

${ }^{1}$ As the rocks dip away from the mountains, as shown in figure 13 (p. 89), lower formations than those exposed in the railway cuts appear toward the south. 'These lower rocks include the coal-bearing formation which crops out in a continuous band from Livingston across the summit to Chestnut. This formation overlies the Colorado shale and is about equivalent to the Eagle sandstone which is so prominent in the rim rock back of Billings. In most places the formation is only 100 feet thick, but about Livingston the sandstone with its accompanying shale beds is about 1,000 feet thick.

Formerly the Cokedale mine, one of the most productive in the State, was in operation about 7 miles west of Livingston and coke was manufactured from part of the coal, but the mine has been abandoned for a number of years and the railway spur leading to it has been removed. 
the mountain on the south, and the remains of old mines can be seen on both sides of the track as far as Chestnut. The coal is of good quality, but on account of the heary percentage Chestnut.

Elevation 5,270 feet. Population 261.* St. Paul 1,024 miles. of ash and the expense of mining, all of these operations have ceased. Just east of Chestnut, however, a branch line turns to the left up Meadow Creek and goes southeastward across the summit to the Trail Creek field, in which mining is still carried on.

About a mile beyond Chestnut the railway cuts through the point of a closely folded anticline in which the Madison limestone forms the core, as shown in figure 16. (See Pl. XV, p. 91.) The exposures are not good enough for the traveler to see all the formations that are involved in the fold, but after passing some coal beds he may see sandstone with red shale (Kootenai, Lower Cretaceous), and then on his right hand a broad band of the same red shale as that which produces the Devil's Slide at Electric. These rocks are standing vertical. Next comes the Madison limestone (Carboniferous), which

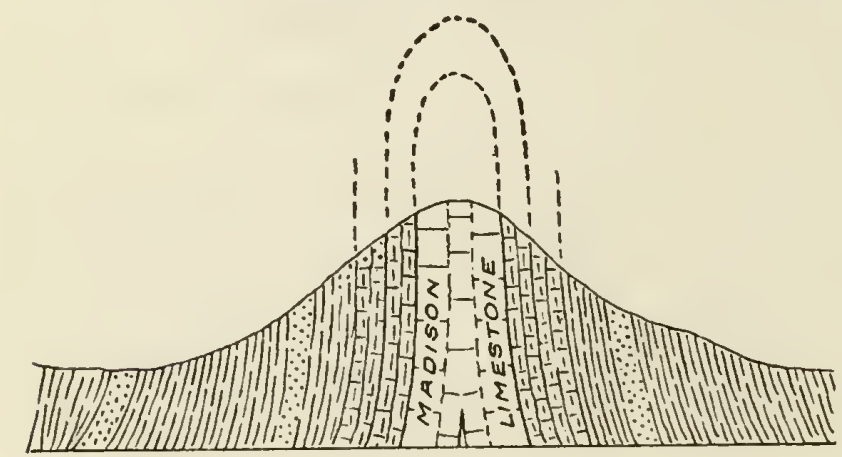

FIGURE 16.--Vertical fold in Madison limestone west of Chestnut, Mont. is the oldest rock exposed. This massive limestone is dissolved and cut by the streams into curious towers and pinnacles, and by the exercise of his imagination the traveler may see resemblances to almost any form he desires. West of this maze of sculptured towers and crags the rocks that were seen on the east side of the fold are crossed in reverse order. This fold, although small in comparison with those that make up the mountains, may give the traveler some idea of the great forces which have crumpled the rocky crust of the earth like paper. No formation is massive enough to resist them.

At milepost 136 the train emerges from the narrow defile of Rocky Canyon and the traveler obtains his first view of the Gallatin Valley. On the left between mileposts 137 and 138 are a few old buildings that once constituted a part of Fort Ellis, an important military post during the Indian wars. This post was established by order of Gen. Terry in 1867 and abandoned in 1887. A little

\section{Bozeman.}

Elevation 4,773 feet. Population 5,107. St. Paul 1,033 miles. is the Gallatin Valley, which is widely known on account of the fine farms it contains and the excellent and diversified crops it produces. The Montana State Agricultural College, situated at Bozeman, has 
assisted materially in the prosperity of the region by the introduction of scientific methods of farming and of handling the crops.

It seems rather strange that a part of the State so far removed from the regular westward routes of early travel and so walled in by the mountains should have been one of the first to be occupied by settlers. This was doubtless due to the description of the valley given by Capt. Clark, who discovered it in 1806. The first effort of the whites to obtain a foothold here was made by fur traders in the vicinity of Three Forks, on Missouri River, but that region, like Kentucky in the early days, was the common hunting and fighting ground of many Indian tribes, and the trading posts were soon swept away.

The first permanent settlement in the valley was made by John M. Bozeman, for whom the town was named, and a party of settlers whom he led into the valley in 1864. Another pioneer who entered the same year was James Bridger, ${ }^{1}$ one of the best-known guides, fur

1 Of all the men who renounced the conventionalities of civilization and cast their lot with the fur traders and trappers of the West, one of the most remarkable was James Bridger. He was well known to almost every western explorer and settler in the first half of the nineteenth century, but there are few written records of the man himself or of his many wanderings from Mexico on the south to the British possessions on the north. He was born in March, 1804. His father, who was a poor tavern keeper in Richmond, Va., moved to St. Louis in 1812, and so the boy grew up in the stirring atmosphere of romance and adventure of what was then the very edge of the great "Wild West." It is therefore of little wonder that at the age of 18 he joined a party under William Ashley to go to the mountains to hunt beaver for the Rocky Mountain Fur Co., which was organized in 1822 at St. Louis. By 1832 he had become a resident partner in this company and was generally recognized as a leader among the explorers and Indian traders of the time.

In the years from 1822 to 1870 Bridger roamed the country from Montana to Mexico and from the Rocky Mountains to the Pacific coast, but his headquarters were at a trading post built by him on the Black Fork of Green River, Wyo., generally known as Fort Bridger. It is said that he was the first white man to see Great Salt Lake (in the winter of 1824-25), but this statement has never been fully substantiated.

Unquestionably Bridger played a most important part in the exploration of the West, and his chief claim for recognition by posterity will rest upon this service. He was probably the best guide in this region and his services were sought by almost every leader of an exploring expedition in the Rocky Mountains. Capt. Gunnison says: "With a buffalo hide and a piece of charcoal he will map out any portion of this immense region and delineate mountains, streams, and circular valleys, called 'holes,' with wonderful accuracy." His name has been perpetuated in many of the natural features of the region, but the interesting personality of the man is largely lost in the hazy distance of a rapidly vanishing past.

Of James Bridger's last years little is known except that on losing his eyesight in 1870 he retired to a farm which he had previously purchased at Washington, Mo., about 5 miles east of Kansas City. Here the once eagle-eyed frontiersman lived in almost total blindness until his death July 17, 1881. Some years ago his body was rescued from an unnamed grave and a marble shaft was erected over his last resting place. 
traders, and scouts of the Rocky Mountain region from 1830 to 1870. His visit here is perpetuated by the names Bridger Range, Bridger Peak, and Bridger Creek.

Recently an effort has been made to apply the name Sacajawea Peak to one of the peaks in the Bridger Range, in honor of the Indian woman who accompanied Lewis and Clark in their journey to the Pacific coast and return and who guided Clark through the Bozeman Pass.

The Bridger Range, which is a conspicuous feature from the vicinity of Belgrade, consists of the upturned edges (see fig. 17) of the rocks of the Great Plains and so is really the Belgrade.

Elevation 4,467 feet. Population 561. St. Paul 1,042 miles. Front Range of the Rocky Mountains. On its east side are the Cretaceous and Jurassic formations that were seen above Livingston, and the crest of the range is made up of the massive and resistant Madison and associated limestones of Paleozoic age. On the western



Figure 17.-Upturned Madison limestone and associated rocks, forming the Bridger Range, Mont., looking north.

slope gneiss similar to that seen on the road to Gardiner and argillite (hard shale) and sandstone of the Belt series are exposed, but within a short distance these rocks are buried beneath the soft clay and sand of the Tertiary lake beds. The Gallatin Valley, like that of the Yellowstone and also other intermountain valleys of Montana, at one time in the past was occupied by a lake. Into this lake were washed clay, sand, and gravel from the surrounding uplands and volcanic ash blown out from the craters of active volcanoes in the vicinity. The ash had the appearance of white dust, being composed of fine particles of glassy lava. On account of the abundance of volcanic ash the sediments deposited in this lake have a light color, which is readily recognized even at a distance of several miles.

At Central Park the railway crosses West Gallatin River and on the left is a beautiful rolling upland country, every Central Park. acre of which is under good cultivation. This upland Elevation 4,324 feet. is on the lake beds and rises toward the southwest, Population 178.* St. Paul 1,047 miles. with the rise of the beds composing it, to a height of at least 500 feet above the railway. Near Manhattan (see sheet 16, p. 112) a branch line turns to the left (south) to 

Anceney. The plain continues northwestward almost as far as Logan,

Manhattan.

Elevation 4,255 feet. Population 570.* St. Paul 1,052 miles.

and throughout that distance the only rocks which are exposed are the gravel and sand of the liver flood plain and the slightly more indurated materials of the old lake beds.

Near Logan the whole of the Paleozoic succession present in this region is exposed across Gallatin River, on the north. The first rocks to be seen are those of the Belt series (Algonkian),

\section{Logan.}

Elevation 4,114 feet. Population 481.* St. Paul 1,057 miles. which are so far away that their character can not be determined from the train, but the traveler, in the course of his journey farther west will see this series in many places and will have opportunity to study it at close range. The rocks across the river near Logan constitute the southeastern limb of a great synclinal trough (see fig. 25, p. 116) and therefore dip toward the northwest, or away from the observer. The next system above the Algonkian is the Cambrian, which is represented by two formations. The lower one (Flathead) is composed mostly of shale and sandstone, but includes a layer of massive limestone through which the railway passes in a deep cut near milepost 164. The Gallatin limestone, overlying the Flathead formation, makes a prominent bluff across the river which can be seen just as

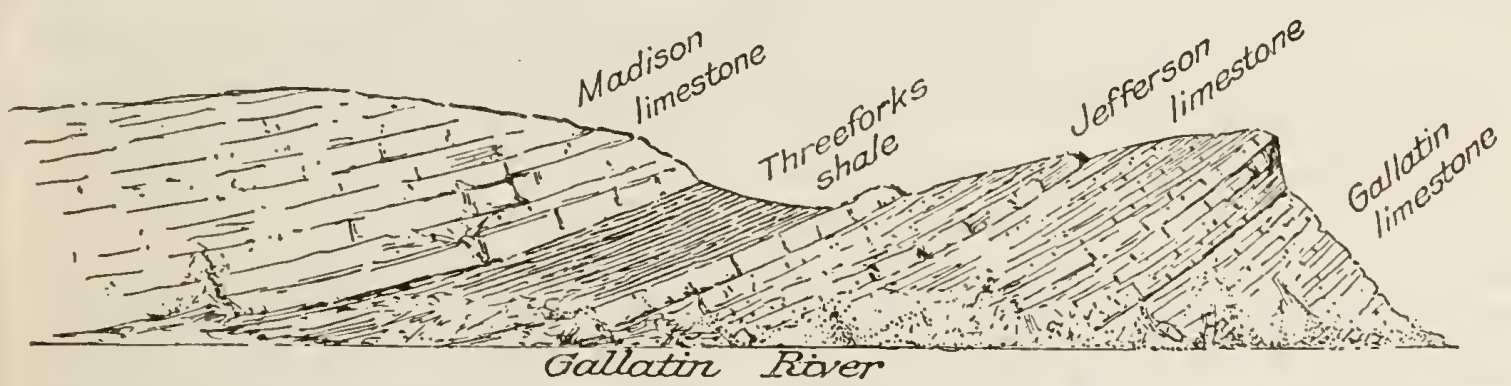

FIGURE 18.-Southeast side of the great synclinal basin north of Logan, Mont., as seen from the station.

the train enters the yards at Logan. The section as seen from the station is represented in figure 18. The Gallatin limestone, at the extreme right of the section, is generally light blue or gray and is easily distinguishable from the overlying Jefferson limestone (Devonian), which is dark and more resistant. 'The Jefferson limestone is one of the most conspicuous members of the section, for it is much darker than any of the other limestones, and as it lies directly below a fairly soft shale it forms a distinct ridge or prominent spurs. It is overlain by the Threeforks shale, which is conspicuous only in that, as it is softer than the limestones on either side, it forms valleys or ravines. Overlying the shale is the massive bluish-gray Madison limestone, which forms the bluff opposite the station and extends westward on both lines of the railway for a distance of at least half a mile.

From Logan to Garrison the Northern Pacific has two lines, the original line turning to the right and running by way of Helena and the other keeping to the left by way of Butte. A description of the Helena line begins on page 116 . 


\section{LOGAN TO GARRISON BY WAY OF BUTTE.}

West of the station at Logan a few outcrops of Madison limestone occur near the track, but these are soon passed; and then the only surface features visible from the train are the broad flood plain of Gallatin River on the north and a bluff composed of Tertiary lake beds on the south. 'The character and composition of these beds and also of similar beds found in most of the other broad valleys of the mountain region are well shown by the bluffs on the east side of the valley of Madison Rives and can be seen by looking baok after passing milepost 3. Here the material is largely sand and the lower layers exposed along the terrace front are hardened into real sandstone. The coarse sand above is less coherent and is being used in the manufacture of cement blocks. Farther south the sandstone is limited to the upper part of the terrave, and all the material below consists of white volcanic ash.

At milepost 5 the railway crosses Madison River. ${ }^{1}$ On the right (north) is the thriving town of Threeforks, situated near and named

Threeforks.

Elevation 4,081 feet. Population 674 .

St. Paul 1,063 miles. from the three forks of the Missouri. This place was first visited in 1805 by Lewis and Clark, ${ }^{2}$ who named the easternmost branch for Albert Gallatin, Secretary of the Treasury; the middle branch for James Madison, Sccretary of State; and the largest and western-

1 Fifty miles to the south Madison River cuts through gneiss in a narrow, rocky canyon. Here the river has been dammed and two hydroelectric plants installed, which develop about 15,000 horsepower and supply current to the cities of Butte, Bozeman, Livingston, and Billings; to placer mines in the vicinity of the plant; and to the cement mill at Trident, below Threeforks. A dam is under construction on Madison River which will store about 350,000 acre-feet of water in what is known as the Hebgen reservoir. It is estimated that this reservoir when completed will increase the total present development along Madison River by about 23,000 horsepower.

2 When Lewis and Clark reached this point in their journey up the Missouri River, they were greatly worried by their inability to find a pass through the mountains or to meet Indians from whom they might obtain information regarding such a pass. They knew not where the river would lead them, nor whether the mountains that lay in their pathway could be crossed. The reader mav obtain some conception of the difficulties that beset them by reading a brief quotation from their" notes written while they were at Threeforks:

"We are now very anxious to see the Snake Indians. After advancing screral hundred miles into this wild, mountainous country, we may soon expect that the game will abandon us. With no information of the route, we may be unable to find a passage across the mountains when we reach the head of the riverat least such a pass as will lead us to the Columbia. Even are we so fortunate as to find a branch of that river, the timber which we have hitherto seen in these mountains does not promise us any fit to make canoes, so that our chief dependence is on meeting some tribe from whom we may procure horses. Our consolation is that the southwest branch [Jefferson River] can scarcely head with any other river than the Columbia, and that if any nation of Indians can live in the mountains we are able to endure as much as they can and have even better means of procuring subsistence." 
most branch in honor of President Jefferson. The western branch, by reason of the volume of water and its greater length, is generally regarded as the real head of the Missouri.

It was here that Sacajawea, the Indian woman who was the real guide of the expedition, found the place of her capture several years before. In recognition of her services in the early exploration of the country a bronze tablet, presented by former Senator W. A. Clark, has recently been placed on a large bowlder in the public park of Threeforks by the Montana Daughters of the American Revolution.

Beyond Threeforks the railway leads up the broad flood plain of Jefferson River and is paralleled by the Chicago, Milwaukee \& St. Paul Railway as far as Cardwell. The flood plain is com-

\section{Willow Creek.}

Elevation 4,165 feet. Population 333.* St. Paul 1,070 miles. posed largely of sand and gravel washed down from the mountains on either side, consequently the soil is thin and the region not well adapted to farming. At Willow Creek, however, soft lake beds cover the coarse gravel, and the country is more fertile.

Beyond Willow Creek the railway approaches the bluffs on the south side of the valley, which consist of quartzite, shale, and limestone, of the Quadrant formation, backed by a higher ridge of Madison limestone. At milepost 17 the river flows in a narrow canyon through a point of this limestone which projects into the valley, and the two railways follow the passageway that the river has cut through the hard rock. ${ }^{1}$

${ }^{1}$ It is by no means uncommon to find that a river has cut its way through hard rock which it might have avoided by pursuing a slightly different course. The explanation for Jefferson River lies in the fact that when the present course was established the valley was not cut to its a deep channel in the soft rocks of its valley bottom and revealed the hard rock beneath, but it was confined by walls of its own slow cutting and could not dodge aside when it encountered a more resistant rock. As the channel was worn lower, the stream became intrenched so deeply in

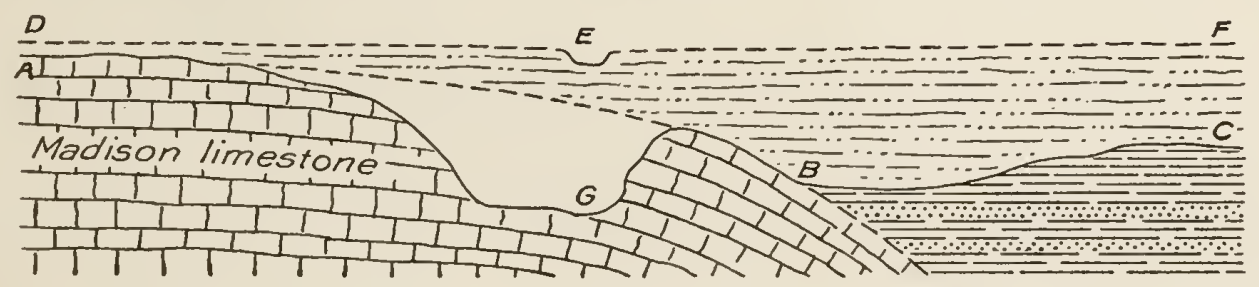

Figure 19.-Diagram to explain the course of Jefferson River west of Willow Creek, Mont. The river cut through soft lake beds $(D E F)$ to hard limastone $(A B)$, but was then so deeply intrenched that it could not avoid the hard rock.

present depth, and the hard limestone that now seems like a barrier in the pathway of the stream lay concealed below the surface. Under such conditions the stream was free to meander from side to side of its flat-bottomed valley, and one of its loops was located directly above the limestone ledge. In time the stream cut this hard rock as to make direct escape impossible, even after the whole aspect of the country had been changed by erosion and easier routes which the river might have taken had become evident.

The situation is represented by figure 19, in which $A B C$ represents the cross section of the valley which one sees on 
From Sappington a branch line continues up the south side of the river for a mile or so and then turns up Antelope Creek to Norris and Sappington.

Elevation 4,205 feet. St. Paul 1,076 miles.

Pony. A short distance beyond the station the Northern Pacific crosses the St. Paul line, and from this point on through the canyon the Northern Pacific is on the north side of the river. About 2 miles above Sappington the river again cuts through a ridge of the hard rocks which project from the great mass on the left. In this canyon the formations composing the earth's crust have been greatly disturbed and tilted up on edge, but it is not easy to understand just how the originally horizontal beds of limestone and quartzite were forced into their present positions. ${ }^{1}$ Here again the stream has cut a canyon across a spur of hard rock projecting from the left, and here, as below Sappington, the stream could have avoided the obstruction by keeping on the soft rocks farther north.

Beyond this canyon the river flows through an open valley composed of Jurassic and Cretaceous rocks which the traveler will hardly

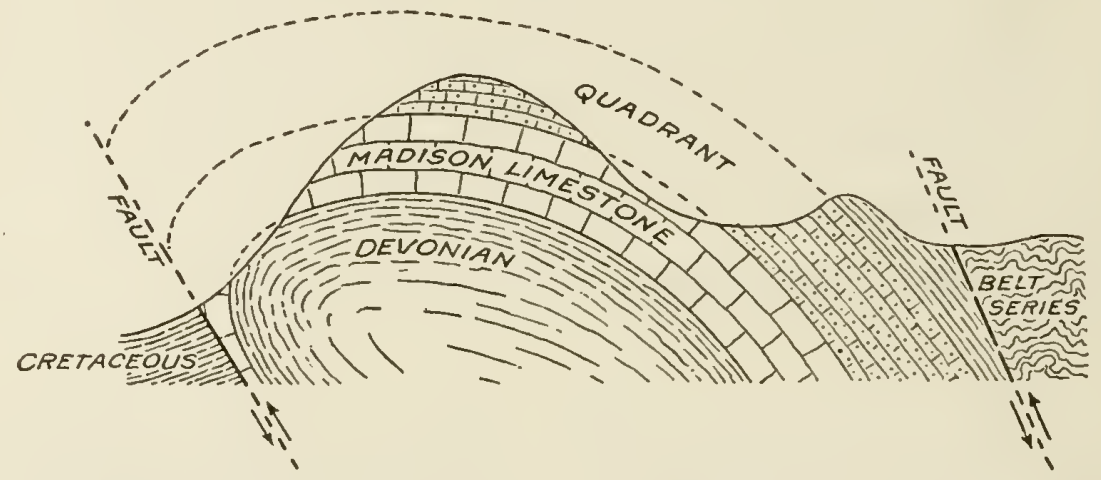

FIGURE 20.-Section of great anticlinal fold near Lime Spur, Mont., as seen from the Northern Pacific Railway, looking west.

be able to distinguish from the train. At milepost 26 he enters the deepest and most picturesque canyon on this part of the line. The rocks in this canyon are in the form of a great anticline, as shown in figure 20, but the fold is so large and so badly broken that its form is difficult to determine. This fold has been produced by

looking west, with the limestone ridge $A B$ projecting into it from the left. When the present location of the river was determined it was flowing on the top of the lake beds, on a surface represented by $D E F$ which was smooth and with no irregularities to prevent the stream flowing in any part of the valley. Let us suppose that it was located at $E$; then some change occurred, such as an elevation of the land or an increase in the volume of water, either one of which would give the stream greater cutting power, and it began to trench the soft material over which it flowed. As it cut deeper it came into contact with the limestone, but the stream was intrenched in its course and so maintained its position, cutting its way down to $G$, its present level.

The soft rocks upon which Jefferson River assumed its present course are the Tertiary lake beds, which probably filled the valley to a depth of several hundred feet.

${ }^{1}$ The peculiar relations of the several formations, as seen in the small canyon 
pressure from the north so great that the rocks have broken, as shown in the diagram, and the Paleozoic formations on the north have been pushed over the Cretaceous formations on the south. Such a break is called an overthrust fault.

The main part of the arch visible from the train is composed of Madison limestone, which is first seen from a westbound train at a point between mileposts 25 and 26 . As shown in the diagram, the limestone at this place is only the broken fragment of the south side of the fold which has been nearly removed by the fault that crosses at the small loading platform on the right. The limestone at this place is overturned, dipping to the north, and it is probable that if it could be followed downward it would be found to grow thinner (beveled) and finally to be cut off altogether by the fault.

At milepost 26 the Madison limestone gives place to the underlying Threeforks shale (Devonian). The upper shaly part of this formation is covered so that it can scarcely be seen, but the lower part, consisting of a conglomerate composed largely of red granite débris, is seen in rugged cliffs on the east side of the track.

In the high mountain on the right there is said to be a wonderful cave in the Madison limestone, which has not yet been thoroughly explored. A quarter section (160 acres) of land, including the cave, was set aside by President Roosevelt on May 11, 1908, as the Lewis and Clark Cavern National Monument. The cavern, however, is so nearly inaccessible that it has been visited by only a few of the more hardy travelers.

Opposite Lime Spur, 8 miles west of Sappington, the beds of Madison limestone outcrop along the canyon wall like great white ribs, making some of the most rugged scenery to be Lime Spur.

Elevation, 4,260 feet. St. Paul, 1,084 miles. found on the road. The limestone is quarried extensively at this place and shipped for the manufacture of cement.

West of Lime Spur the Madison limestone gives place to the Quadrant formation, which is well marked by the bright-red color of some of the limestone and shale beds that it contains. Beyond this band of bright color is a small exposure of Jurassic rocks which are cut off by an immense overthrust fault, shown in figure 20. This fault separates the rocks already described from conglomerate and argillite

west of Sappington, could have been produced only by folding and faulting, which were the results of strong forces that crowded the rocky layers into this region from both the north and the south. This caused them to buckle along east-west lines, much as a pad of paper will buckle when grasped by the hands along two opposite edges and compressed. The great compression which affected the rocks in this canyon produced at least three upward folds or anticlines, and as the movement was strongest from the north the folds were pushed over toward the south. As the pressure continued the rocky folds were broken, crushed, and crowded together into the positions shown on the west side of the river. 
(slate or hardened shale) of the Belt series (Algonkian). The railway follows the west base of a mountain slope of this formation for nearly a mile and then enters the broad valley at the junction of Boulder and Jefferson rivers.

On looking back from the vicinity of Cardwell one is impressed with the abrupt ending of the broad valley a little east of this place

\section{Cardwell.}

and the mountainous barrier that has apparently

Elevation 4,291 feet.

St. Paul 1,088 miles.

been thrown across the pathway of the stream. It is evident that either the mountains have risen across the valley, or the valley about Cardwell has been depressed far below its former level, or perhaps both of these movements have taken place. As the river has succeeded in cutting a canyon through the uplifted mass, the movement must have been very slow, else the stream would have been ponded and found an outlet in some other place.

The valley of Jefferson River, although little above water level, is very fertile, and good crops are raised in the vicinity of Cardwell. In flowing through this flat-bottomed valley the river is not confined to a single channel but breaks up into a number of channels, which

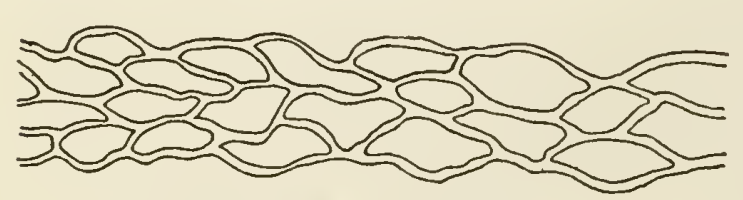

FIGURE 21.-Diagram of braided stream. in turn branch and unite in a complex and confusing manner. Such a system of interlacing channels is called a braided stream. It is caused by the slight fall of the stream, which prevents it from carrying away all the sediment swept in by the numerous tributaries. This material chokes the stream and forces, it to spread into numerous shallow and shifting channels, resembling the strands of a braid, as shown in figure 21 .

The Tobacco Root Mountains are prominent on the south, at Cardwell, and Bull Mountain on the north, though the latter is less conspicuous than the former. The end of Bull Mountain nearest the railway is composed of the Belt series, with the Tertiary lake beds lapping in around its base. The geology of the Tobacco Root Mountains is too complicated to describe here, and the rocks are so far distant that they can not be recognized from the train.

'The railway for a long distance west of Cardwell is on an island in the braided stream, but beyond milepost 36 it crosses to the mainland, and Jefferson River is seen no more in the westward journey. At this place the railway leaves the trail of Lewis and Clark, for they followed up the main river toward the southwest, whereas the Northern Pacific strikes across the range to the west, though it means a climb that even to the modern, high-power locomotive is a severe test. The St. Paul road also turns to the left, but merely to seek another pass in the same range ahead. 
At Whitehall a branch of the Northern Pacific turns to the left, going up the valley of Jefferson River to Twin Bridges and Alder. The town at the end of the line was named from

Whitehall.

Elevation 4,371 feet. Population 417.

St. Paul 1,095 miles. Alder Gulch, which was one of the most noted placer camps in the years immediately following its discovery in 1863 . It is said to have yielded at least $\$ 60,000,000$ and is still producing in a small way. Alder Gulch lies near Virginia City, at one time the capital of Montana. West of Whitehall the road begins the ascent of about 2,000 feet to Homestake Pass, on the Continental Divide 23 miles away.

Just beyond Whitchall the low hills on both sides of the track are composed of soft lake beds which are particularly well exposed just west of Pipestone. In the valley some distance to

Pipestone.

Elevation 4,720 feet. St. Paul 1,012 miles. the south there are hot springs and a hotel. West of Pipestone the cuts along the railway show a finegrained, dense igneous rock (andesite). This is part of a large body of similar rock that lies to the right (north) of the railway and east of the great mass of granite that forms the Continental Divide. Most of the andesite was poured out over this region as lava when the surface was very different from that which the traveler sees to-day, but some of it was intruded from below into the older sedimentary rocks. The volcanic activity which gave rise to the andesite took place long before the granite was intruded, as is proved by the fact that near Pipestone the granite includes fragments of the older rock which were broken off and mixed with the molten granite as it ascended through a fissure in the rocky crust of the earth.

Near milepost 48 the railway enters the great area of granite which extends northward along the range to Mullan Pass, west of Helena. The granite (quartz monzonite) came up from below in a molten condition, forcing the rocks asunder or melting them as it came. It probably did not reach the surface, but since it cooled and solidified it has been exposed by the streams, which have removed the overlying rocks and cut deep ravines in the granitic mass.

As the slope is too steep for a direct ascent, the road winds out and in, around projecting spurs, and up into the heads of valleys, but ever climbing toward the top. On the hills and upland the slopes are smooth and gentle, but in the gulches they are rocky in the extreme.

Near milepost 50 the traveler, by looking ahead on the left, can see a bare dome of granite, known as Spire Rock, the base of which the train will pass farther up the grade. Other knobs or domes of gray granite appear from time to time, standing above the general surface. These landmarks resemble the domes of Yosemite Valley, which are formed of similar rock. Such domes and indeed the great 
number of rounded forms which the granite assumes on weathering are due to the facts that the corners and edges are more exposed to the attacks of weather than broad surfaces are, and that this rock, which is popularly regarded as the type of stability, readily disintegrates or falls to pieces on exposure to the atmosphere. At many places along the track the granite has been reduced by weathering to fine fragments called "sand."

The general slope leading to the summit seems to be an old surface, on which the granite is deeply decayed, indicating long exposure to the weather, but the ravines, which have been cut more recently, are jagged and irregular. The difference in the two surfaces may be seen near milepost 56, where the railway leaves the smooth surface of the upland and enters a gorge which is cut below the general level and which is marked by blocks of all sizes and shapes, including domes, towers, and pinnacles that seem to be scattered over the ground in hopeless confusion.

This combination of smooth upland and rocky canyons continues to the top, which is remarkably free from rugged peaks. Although there is a short tunnel here, the real summit of the mountain is only about 100 or 150 feet above the railway track.

This is the backbone of the continent, the height toward which the train has been climbing since leaving Missouri River at Mandan. The traveler may be disappointed in the Continental Homestake.

Elevation 6,345 feet. St. Paul 1,118 miles.

Divide, for it is no more conspicuous than many of the other ranges in sight. In fact, the Rocky Mountains are a great complex of mountain ranges, no one of which dominates the others to any extent. On the west side of the Homestake tunnel can be obtained a better realization of height, for the descent to Butte is made along a rugged mountain side, and one can look down to the left 1,000 feet to the valley, seemingly almost vertically below. ${ }^{1}$ (See PI. XVI.)

1 The difference in the appearance of the two sides of the Continental Divide is very striking. On the east side the slopes are gradual, so that the railway can follow almost directly up the old smooth slope, but on the west the slope is so precipitous that the road must be graded along the rocky mountain side for 8 or 9 miles in order to get down to the valley floor. So steep and regular a front bordering a broad, flat valley suggests some other mode of origin than erosion, which is the normal agency in the production of mountains and valleys. It gives the impression that this range, instead of owing its relative height to the carving out of the valley by rain and streams, is really separated from the lowland by an actual break in the rocks and has been lifted bodily to its present position, or the valley has been depressed with reference to the mountain. If the rocks along the mountain front south of Butte are examined, evidence will be found to show that there has been recent movement in them and a break (fault) or series of breaks along the west face which allowed the great block of strata on the east side of the fault to be raised at least 1,000 feet with reference to the strata on the other side. The steep mountain front is therefore the cut edge of a great 


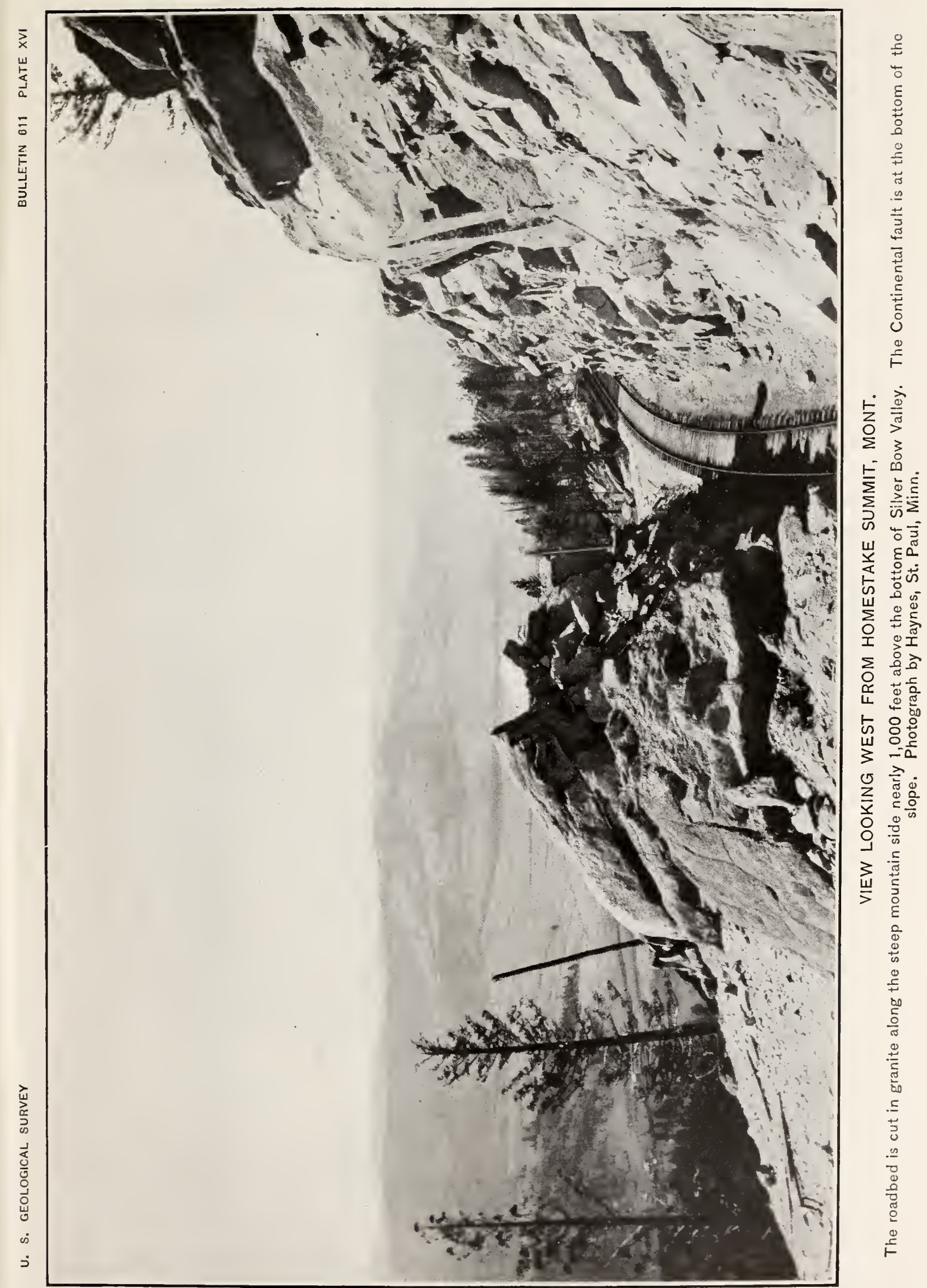




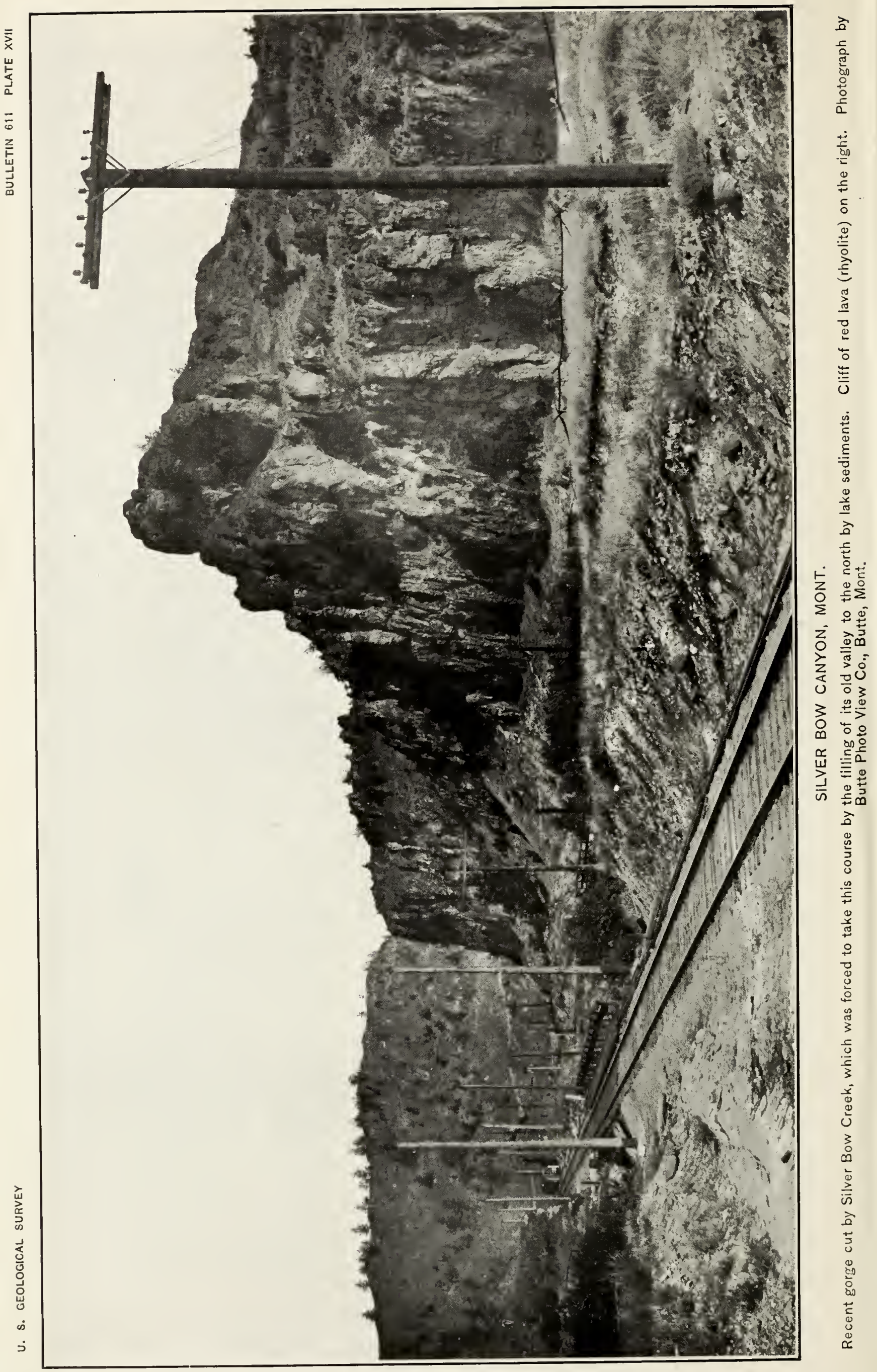


The train winds in and out around the spurs of the mountain, plunging through deep cuts and speeding over high trestles. In the course of a few miles the city of Butte comes into Butte. view on the side of a barren hill. Its general appearElevation 5,490 feet. ance is most desolate. Bare, brown slopes, burnt Population 39,165 . St. Paul 1,128 miles and forbidding, from which all vegetation was long ago driven by the fumes from the smelters, rise from an almost equally barren valley. The slopes, even in the city, are gridironed by railway tracks leading to the different mines, and great mine buildings, tall smokestacks, steel hoist frames, and the heaps of gray waste rock from the mines are the most conspicuous features of the landscape. West of the city is the sharply conical hill, Big Butte, from which the city takes its name. If the traveler enters Butte in the evening he may obtain a beautiful view of the lights of

block of rock that has been tilted gently to the east, and the time since it was raised to its present position has not been sufficient to permit the streams to cut deep ravines on it.

The tilting and lifting of this block of strata have disarranged many of the streams, causing some of them to flow in opposite directions from those which they pursued prior to the uplift. It seems probable also that the block west of the fault was depressed at the same time, for it is difficult to understand how the part on the right rising about 1,000 feet. Now the mountain top, instead of being at $B$, is at $D$, more than 1,000 feet above the valley.

Although the main movement that raised the Continental Divide to its present position is supposed to have ceased, there still appears to be slight movement in the rocks under Butte. Many underground water pipes have been broken, and considerable difficulty has been experienced from the irregular settling of foundations. For a long time

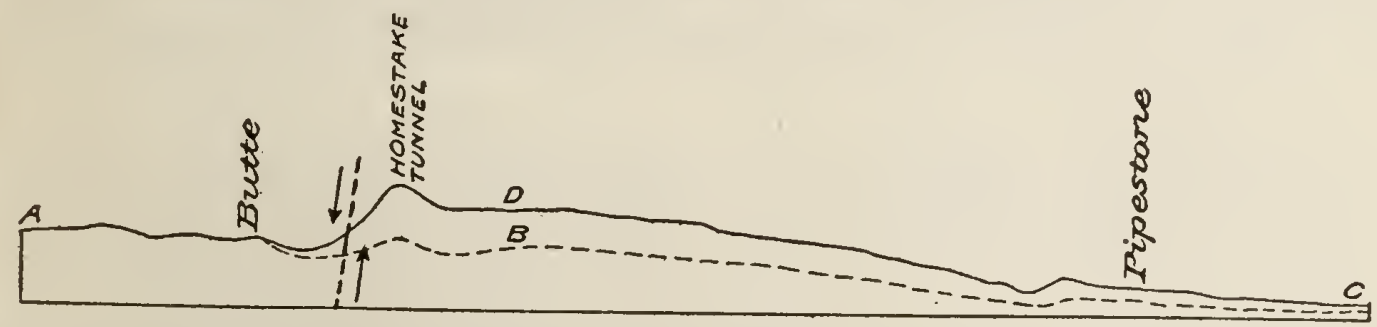

Figure 22.-Diagram of Continental Divide east of Butte, Mont. Before faulting occurred the divide, as shown by the broken line $A B C$, was an upland of slight relief and no higher than Butte is to-day.

the headwaters of Silver Bow Creek could be ponded and produce the flat that can be seen from the train, unless it were the result of the downward tilting of the block west of the fault. The condition is illustrated by figure 22 , in which the cross profile of the range before the faulting occurred is represented by the line $A B C$. The surface around Butte showed little relief, the mountain north of Homestake Pass being only a few hundred feet high. Then came the break along the line indicated by the arrows, these slight movements have been attributed to the extensive mine workings beneath the city, but on close study it was found that water pipes were broken in parts of the town far removed from any mine. This suggests that there may be movement along some of the old fault planes. The United States Geological Survey has run some very exact levels and has set a number of bench marks, so that in the future it can be told positively whether the rocks under the town are moving and, if so, at what rate. 
the city twinkling through the smoke and haze, but in the daylight all beauty disappears.

When the smelters were pouring out their destructive fumes there was not a spear of grass nor a green leaf visibie, but now most of the ore is smelted at Anaconda and Great Falls, and the valley is gradually recovering some of its vegetation. Of the city itself perhaps no better description can be given than that contained in "Along the scenic highway," a pamphlet issued by the Northern Pacific Co.:

Butte is unique among the cities of the world, *** possessing all the united wealth of its tremendous copper deposits, with thousands of well-paid miners. With a large and growing trade in commercial lines, it is an odd and interesting combination of frontier mining camp and modern city, smoke-begrimed manufacturing point, and an orderly, well-kept residential center. It is a city of glaring, violent contrasts, where money seems quite the easiest thing to obtain, where men work furiously and spend the proceeds of their labor with open hand, where the fine instincts of modern city life struggle constantly with the old order of things, and where the mining camp and twentieth-century municipality have been mixed into one rugged mass but have not yet quite blended. Butte boasts with reason that it is the greatest mining camp in the world and may with equal reason boast of its achievement as a modern city.

The positions of the famous copper mines are indicated by the great shaft buildings and tall smokestacks in and about the town. Underground the rocks are honeycombed with workings, and day and night, without cessation, the work goes on at depths which in some of the mines reach 3,000 feet. Up to the present time the value of the metal output of the district has reached the enormous sum of over $\$ 1,000,000,000$. The ore is found in the granite, but the highly mineralized rocks are confined to an area only a few square miles in extent. The mining conditions are described below by B. S. Butler. ${ }^{1}$

${ }^{1}$ Butte was at first a placer camp, and the district was named the Summit Valley district on account of its nearness to the Continental Divide. This is still the official name of what is commonly called the Butte district. Gold was discovered in gravel near the present site of Main Street in 1864, and in the next few years the district produced gold to the value of about $\$ 1,500,000$. While the placers were being operated, efforts were made to work the quartz veins for silver, but without success. About 1875, however, attempts to work these ores were renewed, and the Dexter 10-stamp mill was erected, but important production did not begin till 1876, when the mill was completed by W. A. Clark, later United States Senator from Montana. About the same

time Marcus Daly arrived in the district and began operations in the Alice mine. The camp developed rapidly, and for many years these two men were prominent in mining enterprises in this district. The district continued to be a large producer of silver ore until the decrease in price of that metal in 1893 caused many companies in Butte, as elsewhere in the West, to cease operations.

The presence of copper minerals was noted in the district probably as early as placer gold or the silver veins, but under existing conditions there was little inducement for prospecting the copper veins. Nevertheless some unsuccessful attempts to smelt the copper ores were made in 1866, and early in the seventies some copper ore was hauled 400 miles to 
In the early days Butte, like the other mining camps of Montana, suffered greatly from the lack of transportation facilities, as the only way to get supplies was to have them brought up the Missouri or Yellowstone River as far as steamboats could come and then by team over the mountains to the camp, and the metals produced had

Corinne, Utah, whence it was shipped by rail to smelters in other parts of the country.

The first successful smelter in this district was put into operation about 1880 by the Colorado \& Montana Smelting Co., and this was followed by a rapid development of the copper industry. Production was greatly stimulated in 1881 by the completion of the Utah Northern Railroad (now Oregon Short Line) to Butte, followed a few years later by other railroad connections. The first smelting plants were near Butte, but in 1883 the Anaconda Co. began the construction at Anaconda, in Deer Lodge Valley, about 27 miles from Butte, of a plant which has bəcome one of the largest copper smelters in the world, its capacity being 12,500 tons of ore a day. It was rebuilt in 1902 at a cost of $\$ 7,500,000$. About 1892 the Boston \& Montana Co. erected a plant having a daily capacity of 4,500 tons at Great Falls, where the water power of the Missouri is available. At present there is but one smelter near Butte, that of the East Butte Copper Co.

In recent years the development of large bodies of zinc ore at Butte has led to the construction of plants for its concentration, and the mill of the Butte \& Superior Co. has successfully demonstrated the economic importance of these ores.

The efforts to apply to the complex and enormously valuable veins at Butte that provision of our mining law which permits the owner of the upper part (apex) of a vein to follow his ore under the surface of adjoining claims has burdened the district with protracted and costly litigation, to an extent probably unequaled in the history of mining in other parts of the world.

The Butte district has yielded more copper than any other district in the world, the total output to the close of 1913 being $6,154,196,000$ pounds, or about one-third of the total copper output of the United States. It has produced also $\$ 26,268,500$ in gold, $275,119,000$ ounces of silver, $11,300,000$ pounds of lead, and $181,540,000$ pounds of zinc. The values of these metals are as follows:

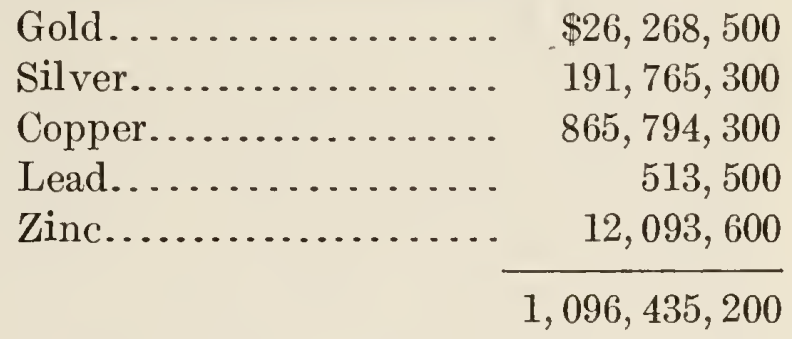

A large part of the output has come from an area of but a few square miles, which so far as value is concerned, has undoubtedly been the most productive metalliferous area of its size in the world.

In recent years some arsenic has been recovered from the smelter fumes and small quantities of the rarer metals have been recovered in the electrolytic refining of the copper.

The metallic deposits at Butte occur near the western border of an area of the granitic rock technically known as quartz monzonite. Near Butte this rock has been intruded by dikes of light-colored siliceous rocks known as aplite and rhyolite. The Big Butte and a large area northwest of it are composed of rhyolite that has risen through openings in the older rocks and covered the surface.

The rocks in the vicinity of Butte have been broken by many faults and fissures, the greatest of which is the Continental fault, described on page 107. Long before the break of the Continental fault and soon after the intrusion and solidification of the granite, the rocks were broken by one series of fissures and faults having a general northwesterly direction and another series having a general northeasterly direction. Water carrying minerals in solution rose along these fissures and deposited the ore in part as a filling of the fissures and in part as a gradual replacement of the rock adjacent to the fissures. 
to be sent out by the same slow, expensive way. 'The city is now served by five railways, three of which are transcontinental lines. ${ }^{1}$

After leaving Butte the railway follows down Silver Bow Creek, which received its name from a party of prospectors who, in 1864, reached the valley in the vicinity of Butte. 'They had an extended discussion regarding the best name for the stream, and while they were talking the clouds broke away and the sunshine falling on the creek as it circled around the mountain suggested the name Silver Bow. At that time the creek may have looked like a silver bow, but now there is little similarity.

The composition of the veins shows a progressive change in metal and mineral composition from a central area outward. The central area contains mainly copper ores. These grade outward into ores containing increasing quantities of zinc, lead, and silver, together with abundant manganese minerals, and showing a decrease in copper, until in the outer zone the ores are valuable chiefly for their silver, gold, and zinc content.

The veins at the surface have all been highly oxidized, and from some the copper has been leached to depths of several hundred feet. In mining some of the veins have been followed to a depth of 3,000 feet and show little change in mineral composition after the first few hundred feet. In fact, in many veins the change in depth is less striking than in an equal distance horizontally.

In the early days of copper mining in the district the ores extracted were of high grade and were smelted direct. Later large bodies of low-grade ores were mined and concentrated at the plants at Anaconda and Great Falls, and the resultant concentrates smelted to recover the metal. More recently a plant has been constructed at Anaconda for leaching the tailings from the concentrating plant to recover the copper lost in the operation. A plant has also been placed in operation at East Butte, by the Butte \& Duluth Co., to leach the copper from oxidized ores. A portion of the copper from Butte is electrolytically refined at Great Falls, but the greater part is sent to the Atlantic seaboard for refining. The water from the mines carries a considerable quantity of copper in solution, the metal being recovered by precipitation on old iron.
1 The railroads were naturally anxious to get the trade of such places as Butte and made every effort to reach them at the earliest moment possible. While the Northern Pacific was pushing its line from the east and from the west, the Utah Northern, now the Oregon Short Line, built into the district from the south, the first train arriving December 21,1881 . This road gave direct connection with the Union Pacific. Although the Northern Pacific had through trains running by way of Helena in 1883, not until 1888 did it make a vigorous effort to reach Butte. At the same time the Montana Central Railroad Co. was organized, and both it and the Northern Pacific began to build parallel lines from Helena to Butte. There was great rivalry in the construction work, but as the Montana Central, now the Great Northern, succeeded in getting its line through first, the Northern Pacific line was abandoned after it had been built as far as Boulder. The Montana Central line from Helena to Butte was opened for traffic on July 12, 1888.

The Northern Pacific, however, did not give up the project of reaching Butte and a few years later built a line from Logan, giving the camp a direct outlet to the east, but still there was no main line through the camp. On September 8, 1893, the Montana Union Railroad was completed by Union Pacific interests from Butte to Garrison, thus giving a direct outlet to the west. This line was used jointly by both the Union Pacific and the Northern Pacific for a few years, but eventually it passed into the hands of the latter, and it is now one of the main lines of the system. 
The valley is wide, the immediate hills are low, and the slopes are gentle and rolling. At Silver Bow station, 7 miles from Butte, the Oregon Short Line (Union Pacific) turns to the Silver Bow.

Elevation 5,345 feet. St. Paul 1,135 miles.

left (south) and after a short climb crosses the summit at Deer Lodge Pass. Beyond Silver Bow station the valley continues open for a distance of 4 miles to a point where the stream enters a very narrow, rugged canyon cut in massive rhyolite, a volcanic rock that covers much of the country west of Butte. The rock when freshly broken is nearly white, but under the influence of the weather it turns to a deep, rich red, which gives a pleasing relief to the somber-gray color of the granite to the east. The Butte, Anaconda \& Pacific Railroad (recently electrified) and the Chicago, Milwaukee \& St. Paul and Northern Pacific railways also occupy the canyon, which, on account of its narrowness, is very much congested. (See Pl. XVII, p. 107.)

Aside from its ruggedness and picturesqueness this canyon has an added interest because it owes its origin to the filling of the original valley on the north with lake sediment and the cutting of a new course by the stream, similar to that of Jefferson River, described on page 101. After the disappearance of the lake Silver Bow Creek came into existence, and on the swampy bottom of the lake it meandered broadly. In its windings it had assumed its present position, when, through the elevation of the land, it gained cutting power and began to deepen its channel. In doing so it encountered the rhyolite, but it continued to cut, and the canyon is the result.

At Durant the train emerges from the canyon into a valley much broader than the one at Butte or Silver Bow. This, the renowned

\section{Durant.}

Elevation 5,174 feet. St. Paul 1,142 miles.

Deer Lodge Valley, is much too large to have been carved by the stream now occupying it. The eastern traveler has doubtless noticed that the valleys in this region are generally different from those with which he is familiar. Valleys that are the result of stream erosion have generally a width that is roughly proportional to the size of the stream, and as a rule they decrease in size toward the head of the stream. In the northern part of the Rocky

Stuart.

Elevation 5,006 feet. St. Paul 1.146 miles.

Mountains many of the larger valleys are out of proportion to the size of the streams occupying them, and hence it does not seem probable that they were formed alone by the erosive action of the streams. ${ }^{1}$

The most conspicuous artificial object in the Deer Lodge Valley is the giant stack of the Anaconda smelter on the left (west), 350

${ }^{1}$ As the origin of many of the broad valleys of the northern Rocky Mountains can not be attributed to erosion, it is manifest that they must have been pro- duced by movement in the earth's crust, either the direct subsidence of the valley itself or the elevation of the surrounding mountain masses. Subsidence may 
fect high, from which issues a never-failing cloud of yellow smoke. The train does not pass close enough to Anaconda for the traveler to see much of the town, which is reached by a spur from the main line at Durant, but he is soon made aware of the effect of the waste waters from the concentration plant, which have flowed down the creek and killed most of the vegetation. Back of the smelter is Mount Haggin, named for James B. Haggin, who for many years was prominent in the mining industry of Butte. On the west side of the valley farther north is Racetrack Peak, which stands like a sentinel keeping guard over the entire valley. In 1910 Anaconda had a population of 10,134 .

have been accomplished in one of three ways, as illustrated by figure 23 . In this diagram $A B$ represents a section across a country with a hilly surface. A broad valley may be formed by a simple depression of the region, as illustrated fault, as shown in $F G$. Here the block of strata on the left has been tilted toward the right and at the same time dropped along the fault $H I$ until a depression and lake are formed. The third and last case is that of a block of the earth's crust


FIGURE 23.-Diagrams illustrating the ways in which the broad ralleys of the Rocky Mountain region were formed.

by $C E$, in which the center $D$ is depressed so much that the tops of the hills fall below drainage level. In such a case the depressed portion becomes a lake, and the lake is finally filled by waste material washed in from the surrounding region. Similar results may be produced by a dropped between two nearly parallel faults, as shown in $J K$.

Deer Lodge Valley was probably produced by one of the three methods described above, but by which one can be told only by close examination and mapping. 


\section{(10.2)}

GEOLOGIC AND TOPOGRAPHIC MAP or THE

\section{NORTHERN PACIFIC ROUTE}

From St. Paul, Minnesota, to Seattle, Washington

Base compiled from United States Geological Survey Atlas

Sheets, from railroad alignments and porfles supplied by

the Northern Pacific Railway Company an:d from addition

information collected with the assistance of this company

UNITED STATES GEOLOGICAL SURVEY

GEORGE OTIS SMITH. DIRECTOR

David White, Chief Geologist $\quad$ R. B. Marshall, Chief Geographer

1915

Each quadrangle shown on the map with a name in parenthesis in the
lower leftc corner is mapped in dotall on the U. S. G. S. Topographic

Sheet of that name

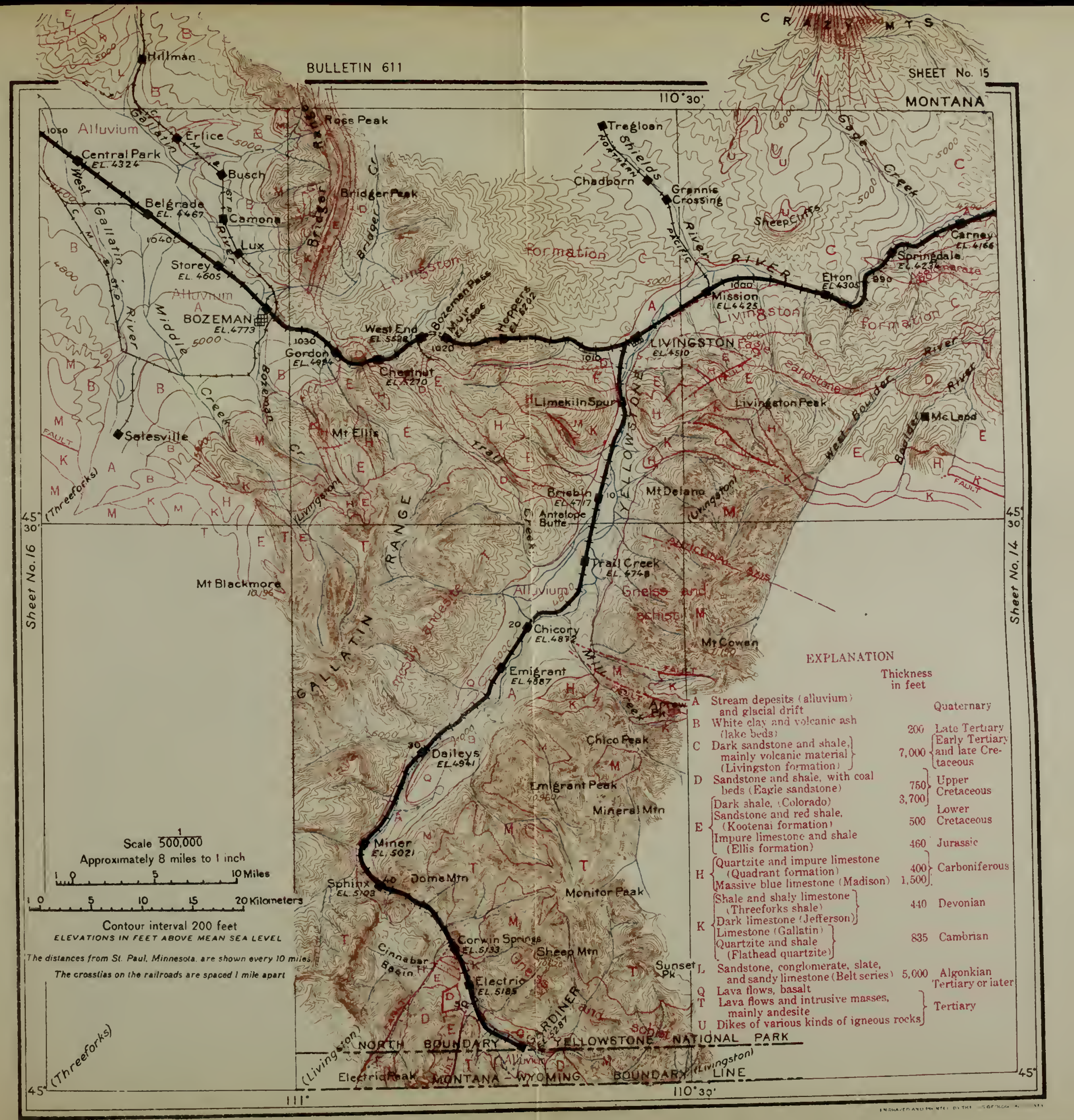



The town of Warm Springs (see sheet 18, p. 134) is built around a group of springs having a temperature of about $150^{\circ}$ and affording a copious flow of water. The valley floor is several Warm Springs. miles wide and is so flat that much of it is swampy. Elevation 4,832 feet. The hills on the right (east), about 500 feet high, Population $866 . *$ are composed of light-colored clay and volcanic ash st. Paul 1,153 miles. and are remnants of the Tertiary lake beds that once filled the valley at least as high as the top of these hills. These materials were deposited in a great lake, which occupied this valley at the same time that similar lakes occupied the Gallatin and Madison valleys to the east. ${ }^{1}$

1 There is no more interesting subject in the geology of the mountain region of Montana than that of the lake beds. They imply conditions which at first sight seem to be anomalous-that is, extensive bodies of water in a rough mountainous region. As shown by the map of western Montana on sheet 18 (p. 134), lake beds have been found in practically every valley from the Yellowstone on the east to the Bitterroot on the west, but they have not been observed in many of the valleys north of Blackfoot River. It therefore seems fairly safe to assume that in Tertiary time lakes existed in nearly every mountain valley in the State. Many of the valleys that to-day are separated were doubtless connected through the canyons, but in such locations the material deposited in the lakes has been removed by the swiftly flowing streams. In other valleys the lake sediments that were once continuous have been separated by the breaking of the earth's crust into great blocks and the tilting of these blocks in various directions. Although the distribution of the materials that were laid down in these lakes indicates that many of them were connected, a study of the bones of animals that lived at the time and were buried in the mud and sand of the lakes indicates that the lake-forming conditions extended over a long period of time, some of the fossils being of Oligocene, some of Miocene, and some of Pliocene age. It is generally supposed, however, that most of the lakes were in existence in the Miocene epoch.

Lakes are abnormal features and have no place in the orderly development of a drainage system-that is, when a drainage system is established on the land there is no tendency in the action of the streams to form lakes, and when such features are formed they are the direct result of some interference with the work of the streams.

Most lakes in mountainous regions are due to the action of glaciers, either in scouring out rock basins or in damming valleys with moraines or with the outwash of sand and gravel from the front of the ice. If the old lakes of Montana were due to the action of ice, there would remain some trace of the glaciers that did the work and of the great dams which they must have built. Dams formed by landslides or lava flows would likewise leave some evidence of their existence, and they could not have been so extensive as to pond the water in all the principal valleys opening out on both sides of the range.

The wide extent of the lakes seems at once to rule out all local causes, so it is necessary to appeal to some cause that would have been operative throughout a wide region and that would have been adequate to produce such results. The great regional cause that is fully competent to pond rivers or produce lake basins is movement within the crust of the earth whereby one area is raised or depressed with relation to another. To the geologist the history of the earth, so far as it has $40063^{\circ}-$ Bull. $611-16-8$ 
Beyond Warm Springs the valley of Clark Fork continues broad and flat; in many places near the stream it is swampy, but on the terraces

\section{Race Tracī.}

Elevation 4,710 feet. St. Paul 1,160 miles. on each side there is good farm land. On the left (west) from.Race Track there are many deep canyons in the side of Flint Creek Mountain, through which glaciers, long past, have flowed down from the high summits even to the level of the main valley. This indicates that most if not all of the side ravines were cut before the glaciers were developed, and that since their disappearance there has been little change in the surface features.

At Deer Lodge terraces about 200 feet high are well developed on both sides of the valley. Apparently these terraces are remnants of the floor of the valley at a much earlier epoch, and

\section{Deer Lodge.}

Elevation 4,530 foet. Population 2,570.

St. Paul 1,169 miles. possibly they may correspond with those observed on the east side of the valley near Warm Springs. North of Deer Lodge there is a terrace on the left, but the one on the right has disappeared and is replaced by low hills composed of soft Cretaceous rock. ${ }^{1}$ been interpreted, consists of the record of an almost infinite number of such oscillations, with accompanying changes in the outline of the land and water.

A regional subsidence in the Rocky Mountains of Montana relative to the plains would readily account for the formation of lakes in all the valleys that were deep enough to lie below drainage level, and this will be accepted as at least a reasonable working hypothesis. According to this view a rough mountain region, probably as mountainous as it is to-day, was depressed hundreds or perhaps thousands of feet, until the streams failed to flow out in their accustomed courses, as the plains beyond were higher than the mountain valleys. The water from the rains and melting snows of the mountains soon filled the valleys until the water rose high enough to discharge over the plains country. Under such conditions there may have been many lakes or there may have been one large lake with ramifications in the valleys among the mountains.

Into the lakes thus formed the mountain streams poured mud, sand, and gravel, the mud being carried far out in the lake to settle as fine clay while the sand and gravel were dropped near shore. At least 600 feet of such material has bien measured in some of the valleys, and probably it was originally much thicker. In some valleys the lakes were evidently filled, and the surface became a swamp in which vegetation flourished and finally was converted into coal or lignite. Such beds have been found near Drummond and Missoula, along the line of the Northern Pacific Railway, and in the vicinity of the Glacier National Park, near the Great Northern Railway.

The climate of this region in the lake period, as indicated by the animals and plants that lived then, seems to have been much like that of central or southern Africa at the present time. The lake beds have not been searched thoroughly, but it is known that mastodons, horses, camels, and rhinoceroses roamed the hills in that far-off time, and that the filled basins were swamps in which flourished a luxuriant vegetation.

1 The broad Deer Lodge Valley extends from Durant northwestward to Drummond, but its continuation beyond Garrison may not be apparent from the train. 
Garrison was named in honor of William Lloyd Garrison. Here the railway line through Butte unites with the original line of the Northern Pacific through Helena. The valley at Garrison

Garrison.

Elevation 4,344 feot. St. Paul 1,180 miles. is much narrower than it is above that place, the cliff on the west being composed of a volcanic rock (andesite) and that on the east of sandstone, shale, (andesite) and that on the east of
lcanic tuff ${ }^{1}$ of Upper Cretaceous age.

[The itinerary west of Garrison is continued on page 127.]

The present condition and possible mode of formation of the valley are illustrated by figure 24 , which represents a section along the railway from Durant on the south to Drummond on the north. As first formed, this valley was a great structural depression in the hard rocks, as represented by $A B$. In that basin sediment accumulated in Miocene time until the depression was filled, as shown in the diagram. The place where Garrison now stands was then near the middle of the basin, and probably only soft lake sediments showed at the surface from Durant to Drummond.

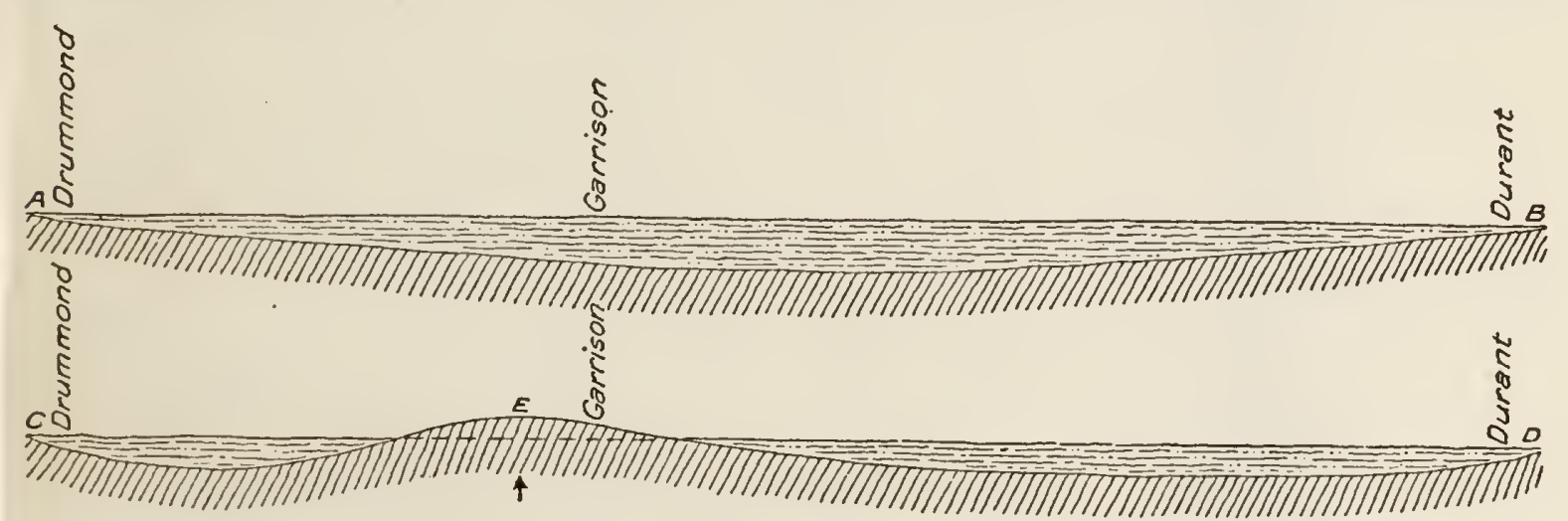

Figure 24.-Sections along Northern Pacific Railway between Durant and Drummond, Mont., showing probable mode of formation of Deer Lodge Valley.

At some later stage the floor of the basin was upraised midway between these two ends (see $C D$ ), so that the lake beds were exposed to erosion. The soft, incoherent lake sediments were soon washed away, and the stream trenched the underlying Cretaceous rocks to a depth of several hundred feet. 'The upraising of the middle part of the trough left a depression at either end, and at the present time these structural depressions are marked by broad valleys, such as can be seen at Deer Lodge and at Drummond. The presence of a broad valley connecting these two marked depressions can be realized only by a study of a contoured map or by a view from some commanding summit on the valley rim.

On account of the deformation of the old basin or trough, the immediate stream channel below Garrison for several miles is a veritable canyon in the Cretaceous rocks, but farther down it opens out into another wide expanse deeply covered by material laid down in the lake.

${ }^{1}$ Tuff is a rock composed of fragments of lava, as a rule more or less distinctly bedded. These fragments may have been blown from a volcanic vent and may have settled down on dry land or in water. Even if deposited on land, the material 


\section{LOGAN TO GARRISON BY WAY OF HELENA.}

A short distance west of the station at Logan (see sheet 16, p. 112) the Helena line crosses Gallatin River and then follows this stream to its junction with the other rivers that form the Missouri. At the

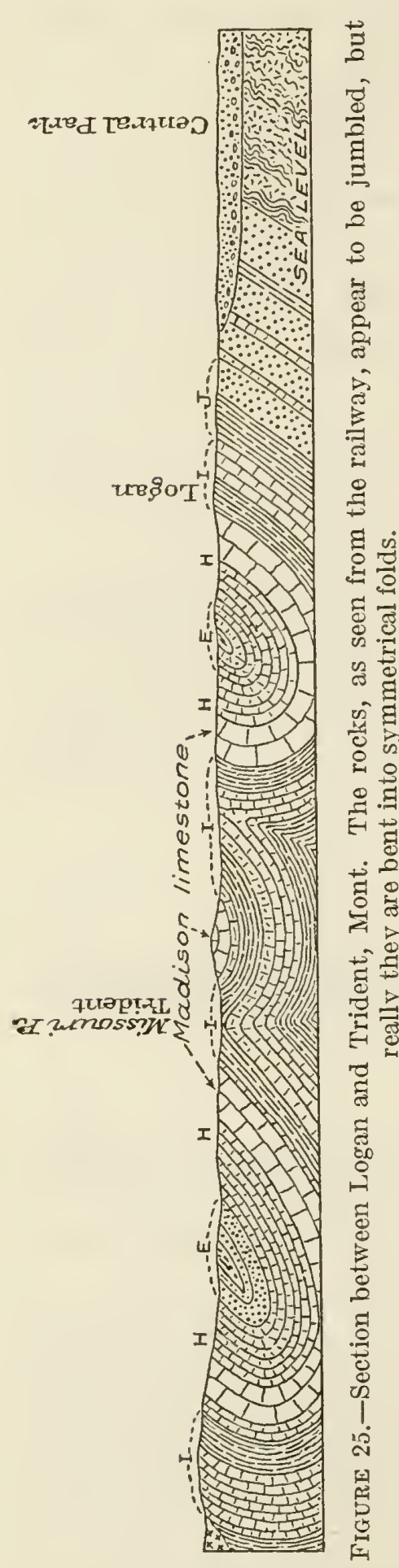

bridge and for a short distance beyond it the railway skirts the foot of a bluff of Madison limestone, but this rock dips below river level and beyond it the bluff is composed of the overlying Quadrant formation. Although the Quadrant resembles limestone it contains little of that rock, being generally composed of quartzite or flinty beds that are much harder and generally of a lighter color than the limestone. These beds in turn dip below water level and the rocky bluffs give way to a low rolling country with swampy land near the track.

The railway follows the flat bottom of Gallatin River for some distance and thence once more follows the cliffs of the Madison limestone, which is brought up from below water level by a great anticlinal fold. On the left (west) there is an extensive flat valley through which Gallatin, Madison, and Jefferson rivers flow on their way to join forces and form Missouri River. They unite at the entrance to the gorge which the combined stream has cut through the limestone and which the train is about to enter. This junction, known as Threeforks, has attracted the attention of every traveler who has entered this region since 1805 , when it was first seen by Lewis and Clark. (See p. 100.)

North of 'Threeforks the river has cut a canyon along a great arch or anticline which at the entrance to the canyon brings up to view only the Madison limestone, but the fold increases in magnitude northward (downstream) and lower formations are successively brought above water level. As shown in figure 25 this fold is not a simple arch, but the force which bent the rocks was so great that the fold was pushed over to the east, or overturned. The rocks were then broken or faulted, as shown in figure 26 (p. 117). 
At Trident, in the canyon of the Missouri, there is a large plant for the manufacture of cement from the Threeforks (Devonian) shale, ${ }^{1}$

Trident. which is obtained from the crushed rock in the overElevation, 4,045 feet. turned anticline shown in the diagram. From ThreeSt. Paul, 1,063 miles. forks.to Lombard, a distance of 15 miles, the Chicago, Milwaukee \& St. Paul Railway parallels the Northern Pacific, on the opposite side of the river.

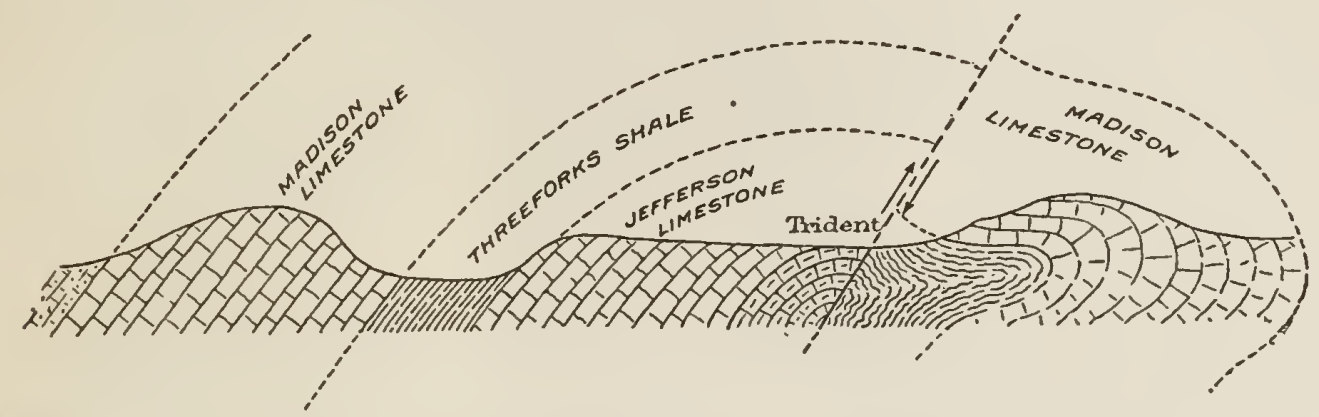

FigURE 26.-Faulted fold at Trident, Mont., looking northeast.

For 5 miles beyond Trident the railway winds in and out on the flanks of the anticline, making a long cut in the Madison limestone at the sharp bend of the river. From this point the river turns back toward the southeast, cutting down through the formations, until it reaches the Belt series - the lowest in the section. Beyond this point the soft material of the lake beds obscures the hard rocks, and the hills formed by those rocks recede a mile or more from the river.

The valley on the right (east) is wide and the hills are low as far as Clarkston siding, but on the opposite side of the river and rudely

\section{Clarkston.}

Elevation 4,002 feet. St. Paul 1,071 miles. parallel with it there is a mountainous ridge, formed by the overturned northwest side of a syncline which lies parallel with the general course of the road and which is shown in figure 25. The southeast side of this fold is obscured by the lake beds, which cover all older forma-

1 The mill at Trident has a daily capacity of 1,600 to 1,800 barrels of cement and is modern in all its equipment, having been erected in 1910. Material most suitable for the manufacture of Portland cement contains approximately 75 per cent carbonate of lime, 15 per cent silica, and 5 to 7 per cent alumina and iron oxides, with very little magnesia and no sulphur. This combination is found in the Threeforks (Devonian) shale, which is quarried extensively along the east bluff of the river. The shale varies considerably in composition, that from the upper end of the cut being very limy and that from the lower end earthy and sandy.
Rock is taken from all parts of the cut and then mixed until the proper proportions of the constituents are procured for the manufacture of cement. The raw material is burned in a revolving steel cylinder, with Red Lodge coal as a fuel. (For a description of Red Lodge coal see footnote on p. 82.) The coal, crushed until 95 per cent of it will pass through a 100 mesh sieve, is blown into the front ends of the revolving cylinders. It burns like gas, producing a temperature of about $3,000^{\circ} \mathrm{F}$. The burned cement is crushed and mixed with a little gypsum to regulate the setting time and is then ready for the market. 
tions as with a mantle, but in the vicinity of Clarkston the Madison limestone is exposed, dipping to the northwest. At milepost 181 begins a long hillside cut in the upper part of this limestone, but as the beds trend in nearly the same direction as the track not much of the formation can be seen. The cut continues to milepost 183, where the valley opens out. On the right the hard formations are covered by clay deposited in the old lake, but on the left the Madison limestone swings across the river and makes a bluff more than 100 feet high above the St. Paul road. Before reaching Lombard the river makes a sharp bend to the left (north) and enters a box canyon ${ }^{1}$ in the Madison limestone. (See Pl. XVIII.) The height of the walls



FIGURE 27.-Fold and fault in the rocks near Lombard, Mont.

of this canyon is about 300 feet, but it decreases downstream, owing to the fact that rocks dip in that direction.

At Lombard the St. Paul line crosses the Northern Pacific and turns to the east up Sixteen Mile Creek, crossing the divide to the head of Musselshell River. Beyond Lombard the thick beds Lombard. of the Madison limestone descend rapidly and pass Elevation 3,977 feet. below water level about a mile from the station. The Population 155.* St. Paul 1,077 miles.

Quadrant formation does likewise, and at milepost 186 attempts have been made to open a mine on a coal bed either in this formation or in the overlying Kootenai formation, but the coal is badly crushed and dirty and the project has been abandoned.

A short distance beyond the coal mine there is a fault that brings the coal-bearing rocks into contact with the Belt series, which consists of red and green shale and argillite, very much broken and disturbed. (See fig. 27.) The Belt rocks form the surface along the river for about 3 miles, including the large bend which the river makes to the left. At milepost 189 the railway crosses this fault again and an igneous mass that was intruded along the fault. The road then enters the Quadrant formation, the lower part of which is generally characterized by very brilliant red limestone and clay. This color is well shown on the right as the train rounds a sharp bend of

1 The term box canyon is applied in many parts of the West to a narrow canyon having vertical or nearly vertical walls. 


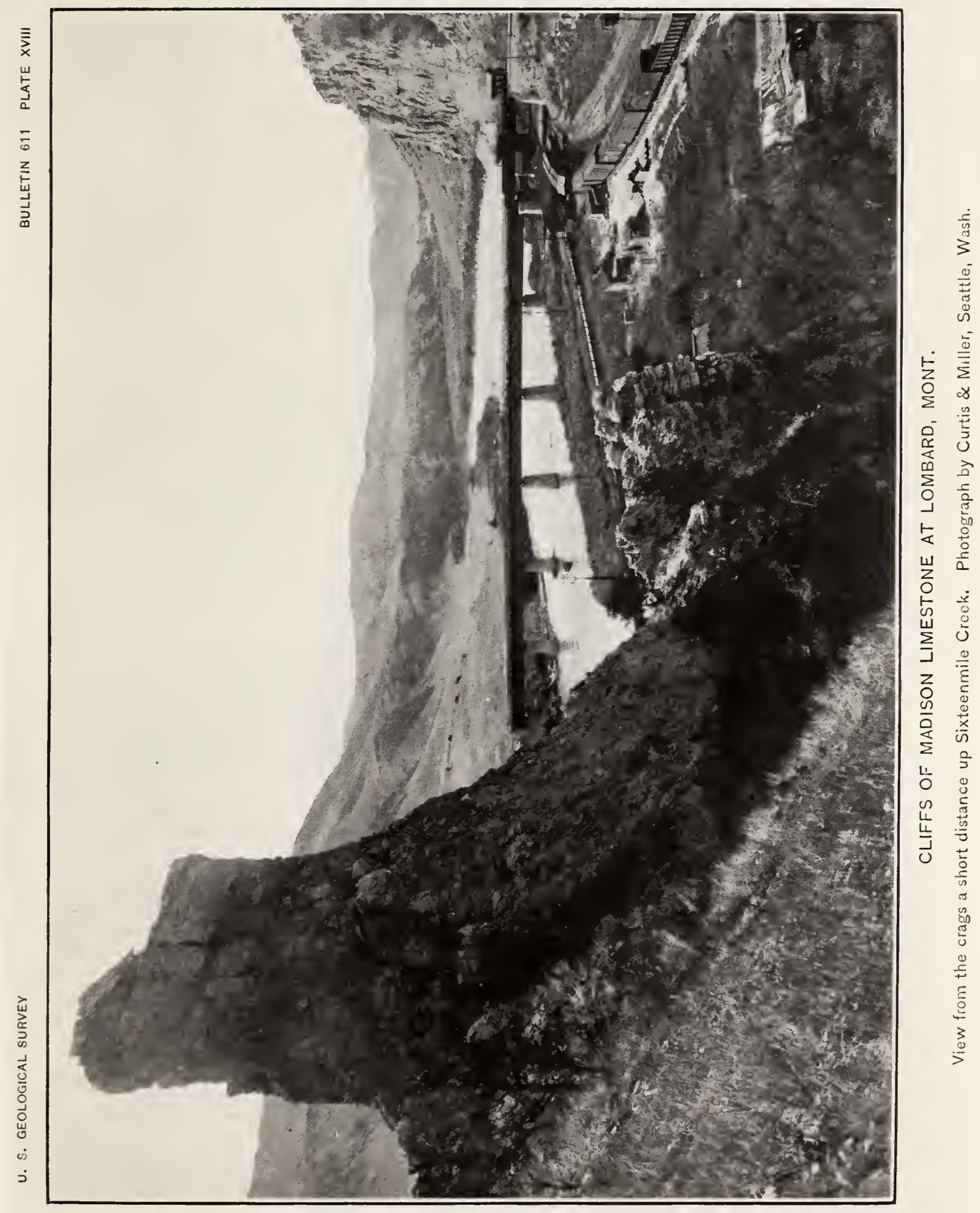




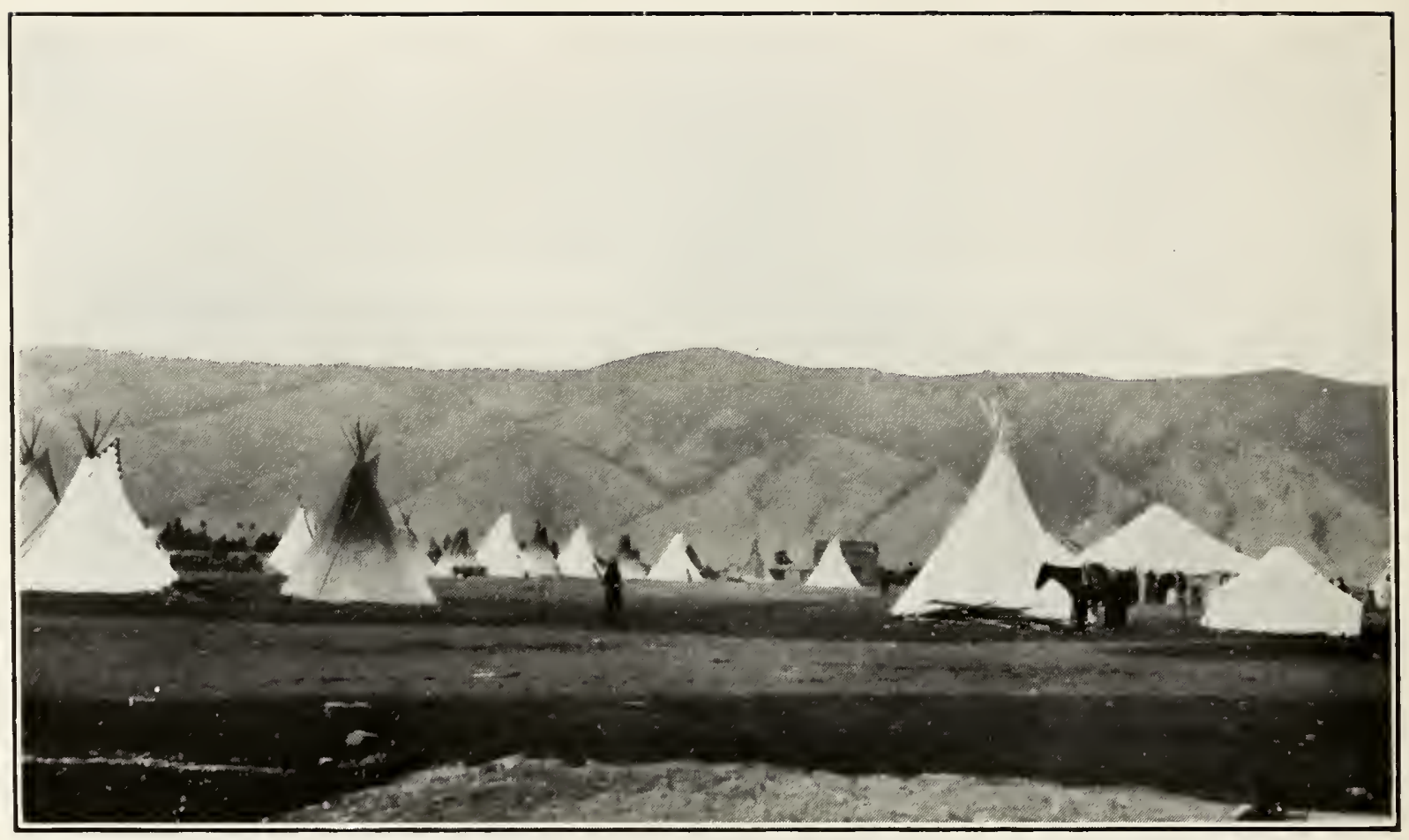

A. SUMMER CAMP OF THE FLATHEAD INDIANS, A FAMILIAR SCENE IN THE JOCKO VALLEY, MONT.

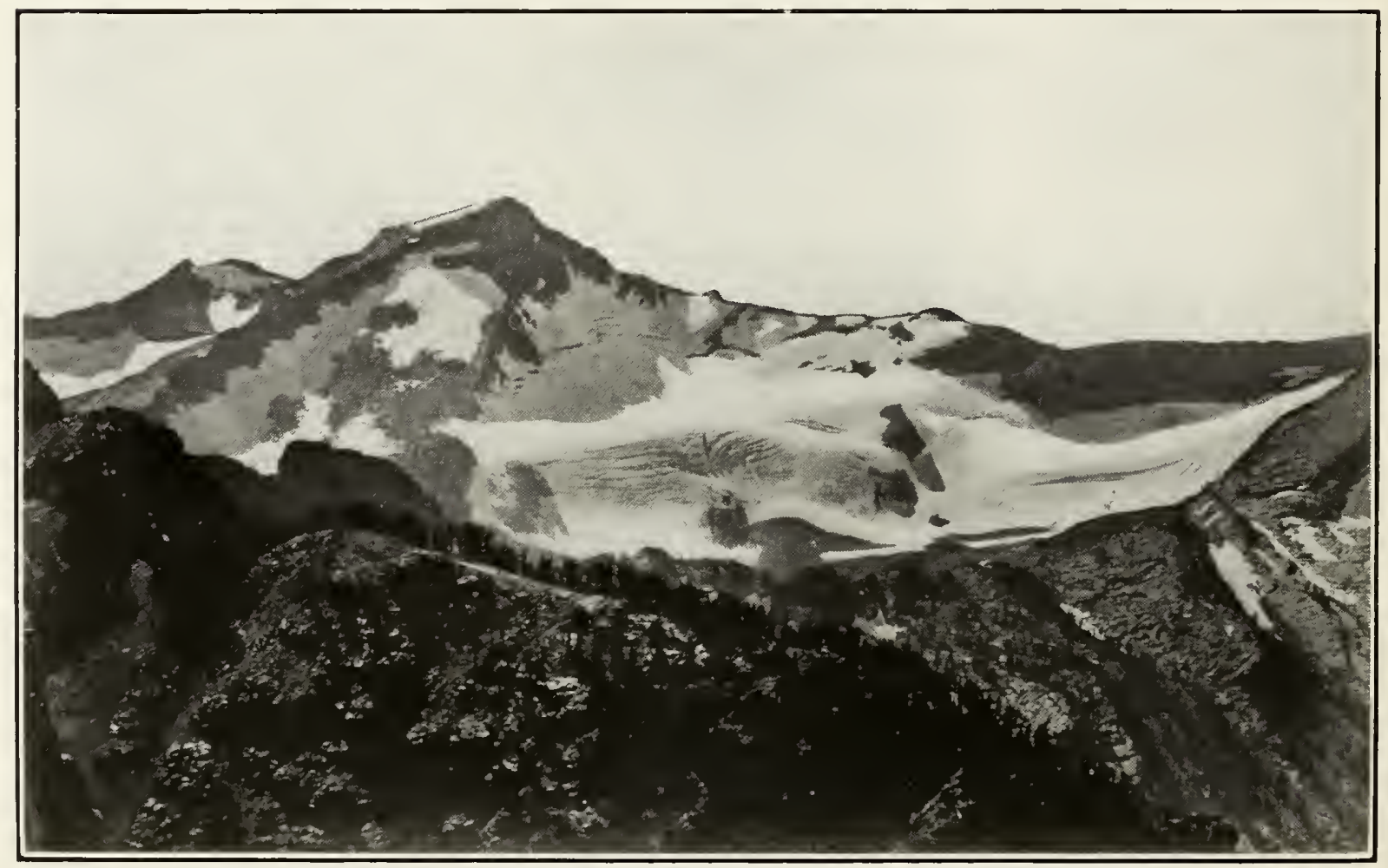

B. GLACIER ON THE NORTH SLOPE OF MCDONALD PEAK, MONT. Photograph by C. D. Walcott. 
the river and it is visible up the hill slope beyond milepost 190, where the train crosses a spring that wells up in large volume from the limestone. The spring forms a beautiful pool, and the stream that flows from it is carried in ditches for a long distance and used to irrigate the bottom land farther down the river.

About 1,000 feet beyond milepost 191 the fault is crossed for the last time, and here the conditions are much like those that prevail at the other crossings. The rocks south of the fault carry a coal bed similar to the one opened near Lombard, and the formation is in contact with a large mass of igneous rock which on the other side rests against the rocks of the Belt series. The Belt rocks are considerably altered, apparently by the heat of the intruded mass, and some mineralization of the rocks has been the result, but although many prospect pits can be seen on the hillsides, little of value has been found.

The hard rocks that form the high hills soon give way to the soft clay of the lake beds, and at Toston the valley opens out on both sides nearly as far as the eye can reach. The river has no

Toston.

Elevation 3,925 feet. Population 384.*

St. Paul 1,086 miles. well-marked channel, and its surface is only a few feet below the general level of the plain. This is the result of the washing in of fine silty material, in which the valley has been cut. The valley was originally formed by some downward movement in the crust of the earth (see p. 112) and then it was occupied by a lake, probably an extension of the body of water that occupied Gallatin Valley in Miocene time. After the lake basin was filled or drained the land was raised, and Missouri River has carved its present valley almost entirely in the soft materials laid down in the old lake. Owing to the softness of this material it is washed into the river at every shower and so the stream is supplied with more sediment than it can carry. This material therefore settles to the bottom, and the channel of the stream is kept at nearly the same level as the bottom land on either side.

Opposite milepost 201 the hills on the left closely approach the river bank and for a height of 400 feet they appear to be composed entirely of clay deposited in the old lake.

The flourishing town of Townsend (see sheet 17, p. 126) is in the heart of a prosperous agricultural region which stretches up and down the river valley for a long distance. A little beyond

Townsend.

Elevation 3,833 feet. Population 759 .

St. Paul 1,098 miles. ing across the level bottom of the Missouri and broken only by lines 
of trees through which the stream sweeps down the valley in broad, graceful curves.

On attaining the top of the terrace it is found to be a sloping plain which rises gradually to the foot of the mountain on the west. The train soon passes Bedford siding, from which the old town, established in 1864, can be seen on the right. This was one of the placer camps in the early days, and it is said that the heaps of gravel marking the location of the old workings are still visible.

The train climbs steadily up the sloping surface of the smooth plain and at Winston the traveler can see a wide sweep of the river valley and the Big Belt Mountains on the right.

\section{Winston.}

Elevation 4,375 feet. Population 127.*

St. Paul 1,111 miles. Across the river on the east, at the foot of the mountain, far in the distance, is Confederate Gulch, from the sand and gravel of which more than $\$ 10,000,000$ in gold has been taken. It is said that in the autumn of 1866 a four-mule team hauled to Fort Benton, for transportation down the river, $2 \frac{1}{2}$ tons of gold, worth $\$ 1,500,000$, nearly all of which had been taken out at Montana Bar and vicinity, near Confederate Gulch.

No hard rocks have been found at the surface near the track, and it is supposed that they are deeply covered by sediment deposited in the great lake previously described. At the summit between Beaver and Spokane creeks a part of the Belt series can be seen in a knob on the north, but its constituent formations are not distinct enough to be recognized from the train. Charles $\mathrm{D}$. Walcott has described this ridge as a syncline composed of the same rocks (the Belt series) as those that are exposed in Helena on the west and the Big Belt Mountains on the east.

The railway follows in a general way the old stage road along which the gold seekers rushed in 1864-65 to the newly discovered Last Chance Gulch, where the city of Helena now stands, and along this road there may still be seen many old houses that resemble the taverns found along some of the famous old stage roads of the Eastern States.

On the right (north) is the broad valley of the lower part of Prickly Pear Creek, its irrigated and well-tilled fields contrasting with the background of rugged mountains. The gently undulating upland upon which the railroad is built is composed of sand and gravel, which are exposed in every cut. Beneath this surface cover are Tertiary lake beds, as shown by a well a little east of East Helena, which passed through 1,200 feet of soft lake beds before reaching the bedrock. 
At East Helena there is a smelter on the left (south), established when this district was a large producer of silver-lead ores, but recently most of the ore smelted here has come from the Coeur

\section{East Helena.}

Elevation 3,902 feet. Population 1,139.* St. Paul 1,126 miles. d'Alene district in Idaho. The railway on the left is the Great Northern line that runs from Great Falls by way of Helena to Butte. At East Helena the Northern Pacific crosses a number of long-distance electric-power transmission lines which extend from the large power plants at Great Falls, Canyon Ferry, and Hauser Lake, to Helena, Butte, and Anaconda, furnishing light and power not only for municipal purposes but also for the great mining and smelting plants at or near these towns.

The traveler has now arrived at Helena, the capital of Montana and a division terminal of the railway, and while the

\section{Helena.}

Elevation 3,055 feet. Population 12,515. engine is being shifted he may be interested in reading a sketch of the early history of the city by Adolph Knopf. ${ }^{1}$

${ }^{1}$ Helena is situated in Lewis and Clark County at the eastern foot of the Continental Divide. Its history dates from 1864, when the town sprang into existence as the result of the finding of extraordinarily rich gold-bearing placers where it now stands. At that time Virginia City, on Alder Gulch, 125 miles to the south, was the great center of population in Montana, as the discovery of gold there in almost fabulous quantities in the previous year had drawn many people into the region. In the spring of 1864 reports reached Alder Gulch of a great strike in the Kootenai Valley, and among those who had taken the trail for the new Eldorado was a party of four prospectors under the leadership of John Cowan. They had crossed the Continental Divide west of the site of Helena when they learned from a party of returning prospectors that Kootenai was "played out." They then decided to turn eastward and continue prospecting, but after a season's fruitless effort they proceeded toward Alder Gulch, determined to make one more attempt to discover gold on a small creek at which some indications of precious metal had been obtained on the outward journey. As one of them expressed it, "That little gulch on the Prickly Pear is our last chance"; and the place thus became known to the party as Last Chance Gulch before the actual discovery of its wealth was made. Gold in paying quantities was found here about July 15, 1864.

The news of the discovery spread quickly and the town grew with the rapidity characteristic of placer camps. On October 30 a meeting was held for the purpose of appointing commissioners to lay out a town, as well as to adopt a name for the settlement. During the following winter 115 cabins were erected in the gulch, and within two years the town had a population of 7,500. In 1867 the telegraph had been extended to Helena from Salt Lake City.

Helena, aided by its situation 140 miles from Fort Benton, the head of navigation on the Missouri, soon became the chief mart of commerce in Montana. Virginia City, then the Territorial capital, had already passed its zenith, but it was not until 1874 that the seat of government was permanently removed to its northern rival.

Gold to the value of $\$ 16,000,000$ was taken from the gravel of Last Chance Gulch, mostly before 1868. In the fall of 1864 gold-bearing quartz veins had been discovered 5 miles south of Helena at the heads of Oro Fino and Grizzly gulches, branches of Last Chance Gulch. The finding of placer and lode gold were thus nearly contemporaneous. The finding of gold in its bedrock source stimu- 


\section{On leaving Helena the traveler has a good view of the setting of} the city at the mouth of Last Chance Gulch, with the prominent

lated the quest for the precious metals all over the Territory.

Silver-bearing lead ores in the vicinity of Wickes, Jefferson, and Clancy, 20 miles southeast of Helena, were discovered simultaneously with the finding of the gold placers. The Gregory lode, one of the earliest finds, was located in 1864, and here, in 1867, was built the second smelter established in Montana.

By 1870 the placers had been largely exhausted and a period of stagnation set in, for lode mining could not flourish without adequate and cheap transportation. The great need of the Territory at this time was an adequate system of railway transportation, connesting with the centers of civilization. Freight rates during the first decade were an enormous drain on the resources of the Territory, costing between $\$ 1,500,000$ and $\$ 2,000,000$ every year, even after the population had shrunk to 18,000 . The chief overland transportation route was Missouri River, by which steamers could reach Fort Benton during high-water stages. But this period of high water lasted from four to six weeks only, and steamers were often forced to stop at the mouth of the Yellowstone, 450 miles distant. On the completion of the Union Pacific Railroad in 1869 , much of the traffic was diverted to this route, Corinne, Utah, being the initial point for freight bound for Montana. This, however, involved a haul by teams of 450 miles, and the tolls were oppressive, costing $\$ 37.50$ for each wagon from Salt Lake to Helena.

In 1883 the Northern Pacific Railway was completed to Helena, and the first train crossed the Continental Divide west of Helena on August 7 of that year. The arrival of the first regular train at Helena on July 4, 1883, was the occasion of a great celebration; but the special feature of the day was the departure of the first "bullion train," carrying $1,000,000$ pounds of silver bullion from Montana's mines.

During the later part of 1883 the Helena \& Jefferson Railroad was built. This line, which is now a part of the
Havre-Butte branch of the Great Northern Railway, connected Helena and Wickes, 20 miles apart. The lead smelter at Wickes was rebuilt and enlarged, so that it was for some years the most extensive reduction plant in Montana and drew ores from a large area, including the Cœur d'Alene district of Idaho. In 1889 it was shut down and dismantled. The same fate has overtaken the many small smelters built in the region tributary to Helena, and at present the only smelter in operation is the East Helena plant of the American Smelting \& Refining Co.

The period from 1883 to 1893 comprises the years during which a large output of silver and lead was maintained. The gold obtained from veins during this period came largely from the district at the heads of Oro Fino and Grizzly gulches and from the Marysville district, 17 miles northwest of Helena, which began to come into prominence in 1880. At present mining activity is, on the whole, at a rather low ebb throughout the region tributary to Helena, the annual production fluctuating around $\$ 1,000,000$. The total yield in gold, silver, lead, and copper aggregates between $\$ 150,000,000$ and $\$ 200,000,000$.

Helena lies on the south side of a great dome-shaped uplift, whose center is somewhere north of the Scratch Gravel Hills, which can be seen on the right (north) from Helena. The rocks dip away from the center of this uplift, but there are many minor folds or wrinkles on the flanks of the dome that in places even produce dips in the opposite direction. About Helena the general dip is toward the south, whereas at Mullan Pass it is toward the southwest. The rocks about Helena are broken by a number of faulta, which in general ray out like the spokes of a wheel from the center of the uplift. The rocks here are much like those exposed about Threeforks, but they have been intruded in many places by masses of igneous rock that have come up from below, and they have been altered by the heat and pressure thus developed. 
peak Mount Helena on the west. About $2 \frac{1}{2}$ miles out the railway crosses the Great Northern line to Great Falls and Havre, and near this crossing the Red Mountain branch of the Northern Pacific turns to the south to a mining district up the valley of Tenmile Creek. Beyond milepost 3 Fort Harrison, the largest military post in the State, is seen on the left (south).

Just west of Helena begins the long grade to the summit of Mullan Pass. The ascent, 1,618 feet, is accomplished in about 20 miles.

From Clough Junction, just beyond Birdseye, a branch line leads northward to Marysville, ${ }^{1}$ one of the most productive mining camps

\section{Birdseye.}

Elevation, 4,231 feet. St. Paul 1,139 miles. in this vicinity, situated just below the crest of the Continental Divide, about 17 miles northwest of Helena.

The rocks in the Front Range in the vicinity of Mullan Pass lie on the southwest flank of the great dome whose center is north of the Scratch Gravel Hills. The regular southwestward dip of the rocks away from the center of this dome is interrupted by a small syncline (a downward fold of the rocks) which lies west of the summit and also by many intrusions of igneous rock, some of which are of great extent, whereas others are small and have had little effect upon the general structure. As the rocks on the east side of the summit dip toward the range, the westbound traveler passes over the several formations in ascending order.

The rocks are poorly exposed about Birdseye and Clough Junction, and the traveler will have difficulty in identifying the Belt series and the Cambrian and Devonian formations. Near milepost 11 the

1 The prosperity of the Marysville mining camp has hinged largely on the fortunes of the Drumlummon mine, the oldest, most steadily operated, and most productive property of the district. The Drumlummon lode was discovered in 1876 by Thomas Cruse, who had been working some placers along Silver Creek below the present site of Marysville, and the mine was gradually developed by him antil 1880, when a 5-stamp mill was erected. In 1882 the property was sold to an English company known as the Montana Mining Co. (Ltd.) for $\$ 1,500,000$. During the operations of this company $\$ 15,000,000$ worth of gold and silver was extracted. In the early nineties the property became involved in protracted litigation, and in recent years the mine has been worked only intermittently. In 1911 the property was sold to the St.
Louis Mining \& Milling Co., which commenced to rehabilitate the milling plant, to operate the old workings, then badly caved, and to search for new ore bodies.

Other notable mines in the district are the Belmont, Cruse, Penobscot, Bald Butte, Empire, and Piegan-Gloster. The district has produced about $\$ 30,000,000$.

The presence of ore at Marysville is due to a small mass of granite that has been forced up from below through the limestone and shale of the Belt series. Some of the ore was probably deposited soon after the intrusion, but the richest veins are supposed to have been formed at a later date. The sedimentary rocks around the granite have been so thoroughly baked that they are changed into hard flinty rocks known as hornstone. The ore occurs along the contact of the granite and the hornstone. 
massive light-colored Madison limestone (Carboniferous) will attract attention on account of its many exposures on the hill slopes. West of the limestone is an intrusive mass of granite (quartz monzonite), which is very extensive, being the same as that which constitutes the mountains about Boulder and the summit over which the Northern Pacific passes east of Butte. It is noteworthy on account of the peculiar way in which it weathers. Some parts seem to be harder than others and less subject to the action of the weather, and these parts stand up as towers and pinnacles. The projecting crags are particularly numerous and fantastic in the vicinity of Austin.

The railway engineers, in order to obtain a regular grade to the summit, found it necessary to make large loops, and the open country about Austin gave them the opportunity they de-

Austin.

Elevation 4,771 feet. St. Paul 1,144 miles.

sired. Just east of the station two stretches of track, one above the other, are visible on the right. The steepness of the grade may be appreciated by listening to the laboring of the engine or by looking back after making the sharp turn above Austin. The track here runs along the contact of the limestone and the granite, and such localities are generally favorable for the deposition of ores. Many prospect pits have been sunk in search of the precious metals, but apparently without success. Above the great loops near Austin the track winds in and out, up the ravines and around the spurs, steadily climbing on the Madison limestone until it arrives at the east end of the Mullan tunnel. Originally the road was carried over the summit, but on the completion of the tunnel the high line was abandoned. The upgrade continues through the tunnel, which is 3,875 feet long, and Blossburg.

Elevation 5,573 feet. St. Paul 1,151 miles. reaches the highest point at Blossburg, at the far end. The tunnel was constructed entirely in the granite, although the limestone extends to the eastern portal and the sandstone and shale of the Cretaceous appear only a short distance west of the other portal.

The traveler has now crossed the backbone of the continent, and as he starts down the Pacific slope and looks back at the summit he is probably surprised at the smoothness of the tops and the absence of the rugged features which most people have, in their minds, associated with Mullan Pass ${ }^{1}$ and the Continental Divide.

1 The first authentic account of a trip through Mullan Pass is that contained in the report of the Government engineers who, in 1853, conducted systematic explorations in order to find the best route for a Pacific railroad. This expedition, under the command of Gov. Isaac I. Stevens, of Washington Territory, established field headquarters at the old mis- sion of St. Mary (now Stevensville), in the Bitterroot Valley south of Missoula. From this camp engineers explored the passes through the mountains and reported on their feasibility for railroad construction.

The two men connected with this work who are best known to the public were Capt. George B. McClellan, who had 
West of the summit the rock is not well exposed, partly for the reason that it is shale (Cretaceous) which is not hard enough to form ridges or knobs. This shale is the youngest rock crossed by the railway in this vicinity. It lies in the middle of the great syncline previously referred to and constitutes the core of the fold. West of this place the rocks should be crossed in reverse order, but they are so badly faulted and cut by intrusive masses that it is very difficult to determine the structure. The most prominent rock on this side of the fold is the Madison limestone which is quarried at Calcium, between mileposts 26 and 27 , and burned into lime.

West of Calcium the rocks are badly broken by faults so that it is almost impossible to identify the various formations from the moving train, but near milepost 28 there is a prominent ledge of quartzite (Quadrant) on the right (north) which carries at its top a valuable bed of rock phosphate. Analysis shows this rock to contain from 40 to 60 per cent of phosphate of lime. This material is valuable as a fertilizer, and the United States Geological Survey has been actively engaged in the last few years in mapping deposits of such rock. It is described by $\mathrm{R}$. W. Stone below. ${ }^{1}$

charge of surveys on the Pacific coast and who afterward came into prominence in the Civil War, and Lieut. John Mullan, who was in charge of an exploring party in the Rocky Mountains and who later achieved local distinction through the building of a military road from Fort Benton to Walla Walla. (See p. 131.)

Late in the summer of 1853 Lieut. Mullan made a scouting expedition to Fort Benton and from that place to Musselshell River by way of the Judith Basin. He tried to induce some Indians to guide him through a low pass that had been reported west of the place where Helena now stands, but the Indians were on a hunting trip for their winter supply of meat and could not be induced to join him. Failing in this, he ascended the Musselshell and crossed the Big Belt Mountains to the site of Helena. He crossed the summit west of this place on September 24, 1853, with little difficulty, through what is now known as Mullan Pass. Twenty years later the same route was followed by the locating engineers of the Northern Pacific and the original line was built across the summit at this place.

1 The bed of phosphate rock just east of Elliston is over 5 feet thick and carries
61.6 per cent of tricalcic phosphate. Detailed examination has shown that within 8 miles of Elliston, on the north of the railway, there is available within easy mining depth approximately $86,000,000$ tons of rock phosphate, or an equivalent of 5,440 acres underlain by a bed 4 feet thick. The phosphate is in a definite layer and is interbedded with other rocks, as coal is. At Elliston the phosphate bed is nearer the railway than elsewhere in western Montana. Phosphate is found in the same formation in the hills 5 miles north of Garrison; near Philipsburg, a town at the end of the branch south of Drummond; at Lime Spur; and at Melrose, 30 miles south of Butte.

When rock phosphate was discovered in the Rocky Mountains a number of years ago, the United States Geological Survey undertook the determination of the geographic extent and quantity of available material. It has been found that rock phosphate occurs in the mountains of Montana, Idaho, Wyoming, and Utah, in quantities so stupendous that when expressed in tons the amount is almost inconceivable. The estimated total in the areas examined in the years 19091913 is approximately 7,777,000,000 long 
At Elliston the red shale of the Kootenai (Lower Cretaceous), followed by the dark shale of the Colorado, is visible on both sides of the valley. A short distance below the town there is a

Elliston.

Elevation 5,061 feet. St. Paul 1,160 miles.

large area of dark-red lava (rhyolite) which extends as far as milepost 35. From this point westward for some distance the valley is much broader than it is near Elliston, and at some stage of the Tertiary period contained a lake. The sediment deposited in this lake can be seen on the right (north) along the track as far as Avon (see sheet 18, p. 134), except where a sharp ridge of rhyolite east of the town Avon.

Elevation 4,702 feet. St. Paul 1,169 miles.

extends from the right and just crosses the railway track. Beyond Avon Little Blackfoot River enters a rugged canyon, at first in red rhyolite and then in thin-bedded red sandstone of the Belt series (Algonkian). These rocks continue a short distance beyond milepost 41 and are separated from the Cretaceous rocks to the west by a small mass of igneous rock (andesite) that has been intruded along the fault.

The lowest formation of the Cretaceous and the first to be seen in traveling westward is the Kootenai, which is visible on the left. This formation, characterized by bands of bright-red shale, is only a few hundred feet thick and is overlain by Upper Cretaceous rocks which extend continuously from this place to Garrison. This overlying formation is undoubtedly the same as the Colorado shale farther east, but its composition is different. In the eastern localities it is mostly a dark shale with only here and there a bed of thin sandstone, but along the Little Blackfoot it is composed of a succession of beds of sandstone and shale with sandstone predominating.

tons, or triple the quantity of anthracite mined in Pennsylvania in the last century. When all the known deposits in these four States have been examined in detail, the estimated available tonnage will considerably exceed these figures.

The most noteworthy characteristic of western rock phosphate is its oolitic texture. (Oolite, from the Greek, meaning egg stone, is applied to certain limestones whose texture suggests the roe of a fish.) The rock is composed of rounded grains ranging in size from the tiniest specks to bodies half an inch or more in diameter. The freshly mined rock usually has a dark-brown or black color, but the weathered material found along the outcrop is a light or dark gray with a whitish to bluish coating that has a tendency to concentrate in a netlike pattern. Rock phosphate is appreciably heavier than ordinary limestone, and some varieties give off a fetid odor when struck with a hammer.

On account of the high cost of transportation the present market of the western phosphates is confined to the Pacific coast States. In 1914 the western phosphate field furnished 5,030 tons, valued at $\$ 15,488$, or an average price of $\$ 3.08$ a ton. This is about one-fifth of 1 per cent of the total phosphate production of the United States, which in 1914 amounted to $2,734,043$ long tons, valued at $\$ 9,608,041$. Phosphate rock is converted into more soluble phosphates for use in the manufacture of fertilizers by treatment with sulphuric acid. As this acid can be made from smelter fumes which ordinarily go to waste, the proximity of phosphate deposits to the great smelting centers of the West is likely to prove beneficial not only to the miners of phosphate but also to the smelter men and the farmers. 

The Cretaceous beds dip gently in various directions, but in general they lie nearly flat and constitute the bottom of a great sag or syncline 15 to 20 miles wide. Although this syncline is flat and broad, it has been subjected to much minor folding or wrinkling, which locally has tilted the beds or even broken them, where the pressure has been more severe.

The Cretaceous rocks are much softer than the older rocks, and

\section{Garrison.}

Elevation 4,344 feet. St. Paul 1,182 miles.

line through Butte. weathering has reduced them to low hills and rounded slopes that are a marked feature of the topography in the vicinity of Garrison. At this village the old main line is joined by the more recent

\section{LINE WEST OF GARRISON.}

The famous Deer Lodge Valley, which is so conspicuous on the Butte line, continues west of Garrison as far as Drummond, but for some distance it is not apparent from the train. When viewed from some commanding eminence the valley is distinctly outlined, but when seen from the river level the immediate bluffs conceal and obscure the background, so that the traveler will probably fail to recognize the broader, more open valley. in the bottom of which the stream has cut its present channel. The broad valley is underlain by soft Cretaceous rocks similar to those which border it on both lines above their junction at Garrison. As explained on page 115, the bottom of the valley bulged up north of the place where Garrison is now located. Clark Fork had already established a meandering course on the sediments filling the old lake basin, and when the bulge occurred the stream simply persisted in its old course, cutting deeply into the underlying harder rocks and preserving all its former sinuosities. The railway can not follow the swings of the stream, because they are too short, so it strikes straight through, tunneling wherever necessary. The St. Paul road lies near the Northern Pacific on the left.

Halfway between mileposts 53 and 54 there is a sign on the left which calls attention to the fact that here on September 8, 1883, was driven the last spike that established the connection between the eastern and the western ends of the Northern Pacific Railway. The event was celebrated in an elaborate manner, and prominent people, including William M. Evarts (as orator), Henry M. Teller, Secretary of the Interior, and Gen. Ulysses S. Grant, were present. The completion of the Union Pacific Railroad, in 1869, had been celebrated by similar ceremonies at Promontory, west of Ogden, Utah, and the gathering in Montana marked the completion of the second great transcontinental line. Since that time other roads have been constructed across the continent without creating any marked attention, but these two roads were the pioneers and the completion of each was an event of nation-wide importance. 
The rocks north of Garrison are mostly of Cretaceous age and correspond to the Colorado shale, which is exposed in the bluff south of Billings. At Billings the formation consists of dark shale containing many marine fossils, but about Garrison it is composed largely of sandstone, conglomerate, and tuff, and no marine fossils have been found in it. The kind of material composing the formation and the character of the fossils indicate shore conditions and fresh or brackish water, instead of the salt water that prevailed farther east. North of Garrison the Cretaceous rocks are cut by igneous rocks that have been forced up through them in great masses and in narrow dikes. The most prominent igneous mass that can be seen from the train is one that crosses the track at milepost 56 . This rock has been quarried for material with which to riprap the slopes of the roadbed where it is washed by the stream. At milepost 57 there is a high, rocky wall on the left composed of sandstone in which there is the standing stump of a tree. It is now silicified but remains as a mute record of a time, long ago, when this country, now so barren of timber, was covered with trees several feet in diameter. About halfway between mileposts 57 and 58 is the mouth of Gold Creek, the creek upon which gold was first discovered in Montana. ${ }^{1}$ The placers are at Pioneer, 5 miles up the creek, and it is reported that at least $\$ 12,000,000$ has been taken from them. They are still producing in a small way. Cretaceous rocks form the surface here, but they are generally soft and give rise to low hills and gently rounded slopes.

At the station of Gold Creek the valley floor merges into the rolling upland that stretches far northeastward to the foot of the Garnet Range, which is composed of Paleozoic limeGold Creek.

Elevation 4,20i feet. Population $730 . *$

St. Paul 1,187 miles. stones and quartzites. At milepost 61 the valley widens, and 2 miles farther west the harder rocks disappear and the valley floor and the slopes are composed solely of the lake beds, which mantle all the older formations. The lake beds continue to milepost 68 , where the Cretaceous rock is again visible on the north.

${ }^{1}$ It is reported that gold was first discovered in Montana in 1852 by a half-breed named François, but better known to his associates as Benetsee. On his return from the gold fields of California Benetsee began prospecting on what is now known as Gold Creek, in Powell County. He found some gold, but did not obtain enough to pay for operations.

The finding of gold at this locality soon became known among the few mountaineers in the country, and in 1856 a party on their way from the Bitterroot Valley, where they had spent the winter trading with the Indians, visited Gold Creek and found more gold than Benetsee had been able to obtain, but not enough to induce them to remain.

Desultory prospecting was done in the years following the visit of this party, but without any definite result until 1862, when rich pay gravel was discovered. Soon after this the extraordinarily rich placers of Alder Gulch, at Virginia City (1863), and Last Chance Gulch, at Helena (1864), were discovered, and these so far overshadowed the deposit on Gold Creek that it was almost forgotten. 
Drummond lies at the intersection of two very broad, flat valleys,

\section{Drummond.}

Elevation 3,967 feet. Population 383.* St. Paul 1,200 miles. one along the main line of the Northern Pacific and the other leading off to the southwest along a branch line running to the mining district of Philipsburg. These valleys are filled with lake sediments, which show that a great lake existed here in Tertiary time.

In the region above Drummond the rocks form a great flat syncline, with the Cretaceous occupying a wide area in the middle. In this central region the rocks were only slightly disturbed, but near Drummond, on the margin of the basin, the rocks are thrown in to great folds which carry the limestone and quartzite beds of the Carboniferous and Devonian high into the mountain tops. In fact the Garnet Range consists of a series of such folds, trending in a northwesterly direction, which become more and more complicated toward the northwest. Clark Fork cuts into the foothills of the range west of Drummond, and the great folds can be seen and studied from the moving train.

From Drummond the railway follows closely the axial line of a large syncline for a distance of about 7 miles. The youngest rocks exposed

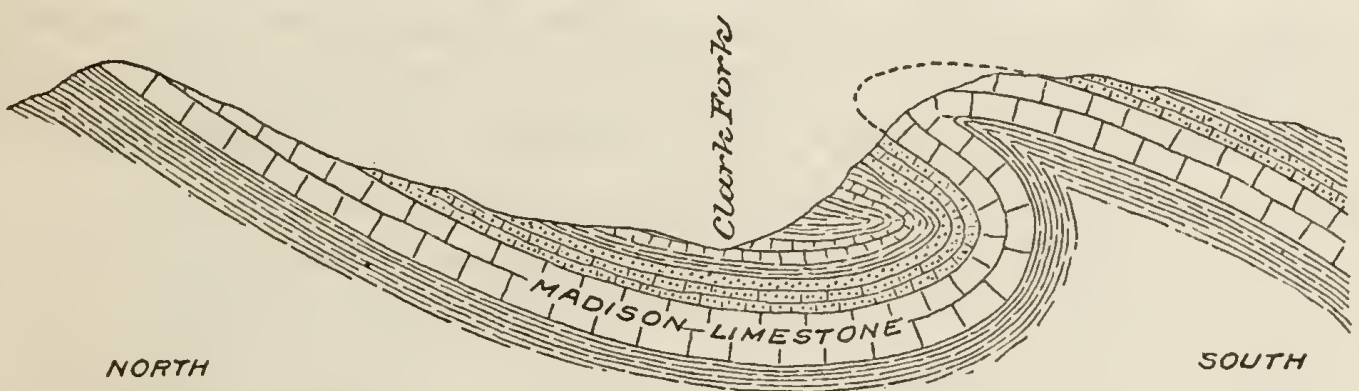

FIGURE 28.-Diagram of fold west of Drummond, Mont. Clark Fork flows near the middle of a great basin, and the Madison limestone is folded back upon itself in the hill on the south.

in this trough are the bright-red and maroon shale and sandstone of the Kootenai. 'The rim of the syncline is formed of the Madison limestone, which 3 miles west of Drummond forms conspicuous cliffs on the south and can be seen on the north in the tops of the high wooded hills about 2 miles distant from the track.

To a point about 3 miles below Drummond the valley is still called the Deer Lodge Valley, but at that point the walls close in, especially on the left, and thence down to Missoula it is known as Hell Gate Canyon. It is probable that this name originated in the vicinity of Missoula, but it is now applied to the whole of the canyon.

At the entrance to the canyon, near milepost 74, the Madison limestone caps the high hill on the south and makes a picturesque setting for the stream and valley at its foot. This cliff can best be seen from a point near milepost 75 late in the afternoon, when the slanting rays of the sun bring out every detail of the towers and pinnacles of the rugged cliff. The limestone appear's to lie horizontal, just as it was laid down on the bed of the ocean, but when studied carefully it is found to be turned completely over, as shown in figure 28 . The over$40063^{\circ}-$ Bull. $611-16-9$ 
turning of the side of the syncline was probably produced by a strong thrust from the southwest which not only caused the rocks to fold in the form of a trough, but continued and pushed the rocks composing the side of the fold far toward the middle of the basin.

Below the cliff of limestone the stream is very tortuous, winding from side to side of the synclinal basin in which it is flowing. The railway originally followed all the crooks and bends of the stream, but now it pursues nearly a straight course, cutting through the points and bridging the stream, or diverting its course where diversion could be accomplished readily. The deep cuts across the projecting points in the bends of the stream afford an excellent opportunity to see the dark-red shale of the Kootenai formation, which is exposed in the middle of the trough.

At milepost 79 the river, accompanied by the railway, turns to the southwest and cuts across the rim of the syncline, which is made up of hard, massive limestones and quartzites (Carboniferous). As these rocks always make rugged and picturesque canyon walls, it is well for the traveler who wishes to obtain a good view to be ready, as it takes only a minute or two to pass through the interesting part of the gorge. Just below milepost 79 the railway crosses the Quadrant quartzite, which makes little showing on the hill slopes. This is soon passed, and then the massive layers of the Madison come into view. As the course of the road changes more toward the northwest, the limestone beds can be seen rising in great cliffs on the left, but beyond another bend to the west they appear in all their ruggedness in the wall on the right. The limestone, stained red or rather splotched with red, rises on both sides to a height of 500 or 600 feet; and the rock is carved into the most fantastic shapes, such as pillars, needles, towers, and minarets - in fact almost every form the imagination can conceive. The combination of rugged forms and striking colors gives to this canyon a character of its own that would be hard to duplicate in any other region. The limestone on the southwest rests against a mass of lava (andesite), which covers much of the country southwest of the river and is exposed in its bluffs in the vicinity of the next station, Bearmouth.

Opposite Bearmouth a small stream, Bear Gulch, enters the river from the right. Here gold-bearing gravel was discovered in October, 1865 , by a party under the leadership of Jack Rey-

\section{Bearmouth.}

Elevation $3,8: 3$ feet. Population 161.* St. Paul 1,210 miles. nolds. In the two years following its discovery it produced $\$ 1,000,000$, and later the yield was increased to many times that amount. The placers are no longer worked, but it is said that gold-bearing quartz veins have been found which may some day bring new activity to this region. 
West of Bearmouth the lava forms the walls of the canyon for a distance of 2 miles to the mouth of Harvey Creek, a small stream entering the river from the south. Opposite and a little below the mouth of this creek there is a syncline extending to the northwest. The rocks in the middle of this basin are the red shale and sandstone of the Kootenai, rimmed about by lower and older formations, the lowermost of which are the limestones and quartzites of the Carboniferous.

About Blakeley siding and for several miles west of it the rocks on both sides of the canyon are red shale or argillite and red sandstone belonging to the Spokane shale (Algonkian). 'This is the first appearance in the westward journey down Clark Fork of this red argillite, which makes most of the walls of Hell Gate Canyon from Blakeley siding to Missoula.

Blakeley siding is well within Hell Gate Canyon, the principal highway by which the white man in the early days and the Indian before him crossed this mountainous region. The first permanent wagon road in this part of the country was built in this canyon in 1859-1862, and is known from its builder as the Mullan road. Its construction is intimately associated with the early development of the country, and a more extended account is given below. ${ }^{1}$

1 Hell Gate Canyon is one of the great natural thoroughfares of the continent. Through this canyon the Flatheads and other tribes of the West journeyed to the plains annually to hunt the buffalo, and through its winding trails crept the stealthy Blackfeet on their numerous forays against their more peaceful neighbors on the west.

In 1853, when the Government engineers were exploring the various passes of the Rocky Mountains to find the most feasible route for a Pacific railroad, they also planned for a military road which should connect Fort Benton, then the head of navigation on the Missouri and the most prominent post on the east side of the mountains, with Fort Walla Walla, which was of equal prominence on the Pacific slope. Lieut. John Mullan was the most ardent advocate of a military road, but he was ably seconded by Gov. Stevens, the leader of the expedition.

The location of such a road east of the Bitterroot Valley (Missoula) was easily determined, but the country west of that valley afforded the greatest obstacles, so in 1854 Mullan explored three possible routes across the Cour d'Alene Mountains in order to determine the best location. These were (1) Clark Fork, Lake Pend Oreille, and Spokane (the town of Spokane was not then in existence); (2) the St. Regis and Cour d'Alene valleys; and (3) the Lolo trail.

Lewis and Clark had already passed over the Lolo trail and had given so graphic a picture of its difficulties that it was not very seriously considered by Mullan, who devoted most of his energies to the other two routes. The route first mentioned, along which the Northern Pacific Railway was subsequently built, was partly explored by Mullan in 1854, but unfortunately the attempt was made in May, when the snow in the mountains was melting rapidly, and he had great difficulty in crossing the streams. He persisted, however, on his course down Clark Fork until he reached Lake Pend Oreille (pronounced locally pon-do-ray), but here he found it practically impassable on account of high water, so he reluctantly gave up this route as impracticable. Mullan then explored the St. Regis and Coeur d'Alene valleys and decided that 
Beyond Blakeley siding the canyon walls are composed of the Spokane shale (Algonkian), and its dark-red color is visible at many places. It is well exposed in a cut by the side of the road, at milepost 87, in a projecting point known as Medicine Tree Hill.

Some Paleozoic limestone and quartzite are to be observed on the right (north) at intervals for the next 5 or 6 miles, and then the walls of the canyon are made up almost entirely of the red Spokane shale. The Algonkian rocks are supposed to be the oldest sedimentary rocks exposed in the Rocky Mountain region. Very few fossils occur in

these afforded the best route. In selecting the Cœur d'Alene route he was influenced by its directness and by the fact that the summit is not especially rugged nor difficult of access, but he failed to realize the severity of the winters on this exposed mountain pass. That in later years he regretted this choice is shown by the following statement: "I have always exceedingly regretted that it was my fortune to examine this route [Clark Fork] at so unfavorable a period, for I have been convinced by later data that it possessed an importance, both as regards climate and railroad facilities, enjoyed by no other line in the Rocky Mountains between latitudes $43^{\circ}$ and $49^{\circ}$." The building of the Northern Pacific Railway down Clark Fork seemed to justify his conclusion, but it must be remembered that at a later date this same company built a branch road over almost the exact route selected by Mullan up St. Regis River, and that only a few years ago the Chicago, Milwaukee \& St. Paul Railway Co. built its main line along nearly the same route. This all goes to show that railway building since the days of Lieut. Mullan, or even since the building of the Northern Pacific main line, has changed, and that now directness of line may be the controlling condition, and the crossing of mountain ranges a mere incident.

Although explorations for a military road were made and a route selected in 1854, actual construction was delayed several years. Mullan was on the ground ready to begin work in that year, under general orders from the War Department, but trouble with the Indians throughout eastern Oregon and Washington pre- vented, and he passed another year without accomplishing any work on his favorite project.

In March, 1859, Congress appropriated $\$ 100,000$ for the construction of the road, and work was begun by Mullan at Walla Walla on June 28 of the same year. The road extended northeastward from Walla Walla to the Cour d'Alene Valley. The first year the road was cleared, so as to be passable by wagon, from Walla Walla to the headwaters of the St. Regis. The next spring Mullan began work where it was stopped the previous autumn and pushed the construction up Clark Fork to Missoula and then up Hell Gate Canyon as far as Garrison. From this point it followed Little Blackfoot River along the original line of the Northern Pacific to Mullan Pass, down on the east side to the vicinity of Helena, and thence north to Fort Benton. By the end of the season the party reached the eastern terminus, but it is needless to say that this great stretch of road was little more than a trail, and much work was needed before it was really passable.

The summers of 1861 and 1862 were spent by Mullan in going back over the line building bridges, making cuts where the canyons were narrow, and relocating the road about Cœur d'Alene Lake, where the ground proved to be soft and marshy.

The road thus built had a length of 624 miles through the roughest part of the Rocky Mountains and cost $\$ 230,000$. It was never used to any extent for military purposes and soon fell into decay, except where it was kept up by the local authorities. About 20 years later it was supplanted by the Northern Pacific Railway. 
them, but those that have been found are fresh-water forms, indicating that the sediment forming the rocks was deposited in a lake or lakes.

Many of the beds of sandstone are beautifully ripple marked, showing that the water in which the sand was deposited was so shallow that the waves piled up the sand in ripples or ridges. They also show cracks, indicating that at times the water receded, allowing the material composing the bottom of the lake to dry and crack irregularly, as mud deposited along a stream to-day will crack when it dries. Another indication of shallow water, or of no water at all, is the preservation of the prints of raindrops, which, after the millions of years that have elapsed since these rocks were mud on the shore of some lake, indicate the direction from which the storm came that drove along the coast. This may not be of great importance, but it illustrates how well nature has preserved the record of events of that far-off time, if only we will learn to interpret it.

The Spokane shale is well exposed in the portals of the tunnel between mileposts 94 and 95 and can be seen to good advantage from the observation car. From Bonita to Missoula the

\section{Bonita.}

Elevation 3,594 feet. St. Paul 1,224 miles. walls of the canyon are steep and high but not particularly rugged. They are composed almost entirely of the Spokane shale, which supports a much heavier growth of pine trees than the other formations. This is particularly noticeable on the south side of the canyon, or on the northward facing walls. The difference in the vegetation on the two sides is due to the difference in the amount of moisture conserved. The northward facing slope is not exposed to the direct rays of the sun, and hence the moisture in the soil is not readily evaporated and trees thrive better than they do on the opposite side.

Below Clinton the character of the canyon is much the same as it is above that place. The hills range from 1,500 to

\section{Clinton.}

Elevation 3,490 feet. St. Paul 1,231 miles.

Bonner (see sheet 19, p. 144), at the mouth of Blackfoot River, is

\section{Bonner.}

Elevation 3,321 feet. St. Paul 1,242 miles. 2,000 feet in height above the stream, and the slopes are everywhere strewn with the débris of the red shale of the Spokane.

noted for its lumbering industry, being the location of some large sawmills. The river has been dammed below the mouth of the Blackfoot, affording about 4,000 horsepower, which is converted into electricity and transmitted to Missoula and the towns of the Bitterroot Valley.

At Bonner the traveler again comes upon the route of Lewis and Clark, for on his return trip Lewis ascended Hell Gate Canyon as far as this point and then turned to the north up Blackfoot River. Six 
miles west of Bonner, Hell Gate Canyon terminates abruptly, ${ }^{1}$ and a short distance beyond this termination is situated the flourishing town of Missoula.

From the station at Missoula a good view may be obtained of the steep side of the valley, which rises like a mountain on the east. The knob north of Hell Gate Canyon is Jumbo Mountain, Missoula. and the larger mass south of the canyon is University Elevation 3,223 foet. Population 12,869. St. Paul 1,248 miles. Mountain. The slopes of these mountains are free from trees and brush, and on looking closely it will be seen that they are marked by many horizontal lines (fig. 29) which become very prominent when they are covered by a



FIGURE 29.--Morizontal beach lines on Mount Jumbo, as seen from railway station at Missoula, Mont. slight fall of snow. These lines have attracted general attention, and many theories regarding their origin have been suggested. Some have supposed that they are stock trails, but it is now generally agreed that they are undoubtedly beach lines cut by a body of water that occupied the broad valley in which Missoula is situated and also many other valleys in this part of the mountains. According to the markings on the valley walls, the water must have been nearly 1,000 feet deep where Missoula now stands. ${ }^{2}$

Missoula, one of the most important towns of western Montana, is situated on a broad plain at the lower end of Bitterroot Valley, which extends southward for a distance of at least 75 miles. It is the junction of a branch line of the railway which runs up the Bitterroot Valley to Stevensville, Hamilton, and Darby. At Missoula is located the University of Montana, and a little below the town, on the opposite

1 The east wall of the valley at Missoula is so abrupt and regular that it at once suggests a fault-that is, the mountain has risen with relation to the valley or the valley has dropped with relation to the mountain. Farther south, as Waldemar Lindgren has shown, the Bitterroot Valley is bounded on the west by a great fault along which the rocks of the mountain have been raised or those on the east depressed, forming the long, straight Bitterroot Valley. The effect of the movement on these two fault planes, if 'they are continuous along both sides of the valley, is the depression of the block of strata between them forming the floor of the Bitterroot Valley, as illustrated in figure 23 (p. 112). As the hard rocks under the valley are poorly or not at all exposed, the evidence of the fault at Missoula is to be found only in the topography.

2 The horizontal beach lines that are so well shown along the railway at Missoula, in the Jocko Valley, and at Plains, below Trout Creek, in the valley of Clark Fork, 

side of the river, is Fort Missoula, one of the principal military posts in the mountain region.

and also off the railway in the Bitterroot Valley and across the divide north of Ravalli were undoubtedly formed by a continuous body of water that at some recent geologic date occupied these valleys. On account of the excellent development of the beaches of this lake at Missoula, it has been named Lake Missoula. (See map on sheet 19, p. 144.)

Lake Missoula must have occupied the valley at a very recent date, for the faint shore lines would have been entirely obliterated if the lake had been here long ago, and little or nothing would have remained to tell of its existence. However, although it was geologically recent, it existed many, many years ago, probably long before the Indians began to roam over these hills and mountains.

Lakes are transient features and are due to some interference with the normal development of the drainage system of the region. What then occurred in this region to change the drainage and to cause the ponding of the streams at Missoula to a depth of 1,000 feet? The altitude of the highest beach line that has been observed is about 4,200 feet at Stevensville, in the Bitterroot Valley south of Missoula, and as the altitude of Missoula is about 3,200 feet, the depth of the water must have been about 1,000 feet.

When the beaches are traced northward and westward, they are found to terminate just in front of the southernmost extent of the great glacier that came down from the north. As the beaches thus show a definite relation to the ice front and as they seem to correspond in time with the glacial epoch, it seems altogether probable, if not certain, that Lake Missoula was due to the damming of Clark Fork by the ice. The great glaciers that swept down from Canada at this time are known to have occupied all the mountain valleys to the north, filling them to depths which range from a few hundred to perhaps thousands of feet. One lobe of this mass of ice came down the Flathead Valley as far as the Northern Pacific Railway at Dixon, and another down the broad valley from Bonners Ferry, on the Kootenai, by Sandpoint to the vicinity of Spokane. The intermediate valleys in the Cabinet Range have not been examined in sufficient detail to say whether or not they were also filled with ice, but it seems probable that at least some of them afforded avenues for the southward flow of small tongues of ice nearly or quite to Clark Fork.

All the evidence points to the conclusion that the main valley of Clark Fork in the vicinity of Pend Oreille Lake was effectively blockaded by the ice, and that the low valleys to the north were shut off as avenues of escape for the waters of the upper valleys. Such a dam would necessarily be inconstant, allowing the depth of water to fluctuate considerably, and consequently many shore lines would be cut on the rocks; but none of them would be strongly marked, as the water was not held long enough at any one level to permit deep cutting.. The shifting of the positions of the several ice lobes would also tend to produce a difference in level of the outlet and a corresponding change in level of the surface of the water. As the glacial epoch waned the ice probably grew thinner and thinner and the lake shrank in a corresponding manner, until at last the present outlet was opened and the water disappeared.

Although the general history of Lake Missoula is about as sketched, a number of facts now known indicate that many modifications may be necessary when the final history of the lake is written. The most difficult to harmonize with the theory given above is the difference in the height of the beach lines in the several valleys. Thus at Stevensville, in the Bitterroot Valley, they extend up the valley wall to an altitude of 4,200 feet; north of Dixon beach lines are well developed up to 3,950 feet; at Plains they can be traced up to an altitude of 3,100 feet, but above that level the hills break away and it seems certain that the uppermost terraces are not represented; near Trout Creek they apparently cease at 3,500 feet; and on St. Regis River 
The first permanent settlement in this region was made in 1841, when Father De Smet founded the Mission of St. Mary at the point where Stevensville is now located. He established the mission for the Salish or Flathead Indians, who then occupied the valley but who later were transferred farther north to a reservation which is crossed by the Northern Pacific in the vicinity of the towns of Ravalli and Dixon. Father De Smet was joined in 1843 by Father Anthony Ravalli, who labored faithfully with the Indians throughout a long and busy life. These two priests had great influence on the early settlement of this region, and their services have been commemorated by the naming of towns in their honor.

It was to the entrance of the canyon above Missoula that the name Hell Gate was first applied. The Blackfeet Indians, residing on the plains east of the mountains, were noted fighters; and many were the forays they made through this canyon on the more peaceful Flatheads on the west. The French traders and trappers, on account of the devastation wrought by the marauding parties that emerged from the mouth of the canyon, called it Porte d'Enfer, which may be translated Hell Gate.

The isolation of Missoula in the early days and its distance from the outside world are well illustrated by the slowness of returns from some of the elections; thus it is reported that the settlers in the Bitterroot Valley who voted" in the presidential election of November, 1856, did not know the result until April, 1857, when an Oregon paper describing how Buchanan had been elected was brought into the valley. ${ }^{1}$

no beach lines have been found, but extensive terraces that probably record the height of the water and should be correlated with the uppermost beach lines in other valleys are well developed at Haugan and Saltese, at an altitude of 3,450 feet. It is true that some of these altitudes have not been accurately determined, but there seems to be a gradual decrease in the altitude of the terraces toward the northwest that indicates a depression of the earth's crust in that direction since the beaches were formed, or a rise in the surface toward the southeast. Such a movement is also indicated by the recent canyon cut by Clark Fork between Missoula and the mouth of St. Regis River.

Glacial Lake Missoula had so transient an existencs that very little of the sediment deposited in its waters can now be identified, and it is possible that some of the sand and clay noted as Tertiary lake beds were laid down in Lake Missoula.

1 Oregon, which was organized as a Territory by act of Congress in August, 1848, included what is now the county of Missoula, Mont. By an act of Congress approved March 2, 1853, the Territory of Oregon was divided, and the country including Missoula County became a part of the Territory of Washington. In December, 1860, Spokane County, which had included this region, was divided, and Missoula County was organized, with the county seat at the store of Worden \& Co. Missoula County remained in Washington Territory until Idaho was organized, on March 3, 1863, when it became a part of Idaho Territory. On the organization of Montana, in 1864, Missoula County became a part of that Territory. 
As the train leaves Missoula, the traveler can obtain on the left (south) a good view of Lolo Peak, a high summit of the Bitterroot Range, which lies south of the Lolo trail that played so important a part in the early exploration of this country. He can not, however, see much of the Bitterroot Valley, for the view is obscured by some low hills on the south side of the river.

The railway runs through a broad valley, with low, rolling hills on the right composed of Tertiary lake beds in which, near milepost 121, low-grade coal is being mined in a small way. The faint beach lines of glacial Lake Missoula, which are so prominent on the side of Mount Jumbo, can be followed with the eye along the north side of the valley for several miles.

At De Smet, 7 miles west of Missoula, the road branches, one line turning to the left (west) and following Clark Fork to Paradise, with a branch across the mountains to the Cœur d'Alene

De Smet.

Elevation 3,237 feet. St. Paul 1,255 miles. mining district, and the other, the old main line, turning sharply to the right and reaching Jocko Valley through the Coriacan Defile. This narrow pass is reported to have been an Indian highway and it takes its name from Chief Coriacan, of the Flatheads, who was surprised and killed here by the savage Blackfeet:

The railway winds around the hills, through cuts in the Tertiary lake beds, and passes over the Marent viaduct, which has a height

\section{Evaro.}

Elevation 3,971 feet. St. Paul 1,265 miles. of 226 feet. It continues up through a narrow gulch in the Belt series until finally it reaches a broad flat at Evaro, near the summit of the ridge. This place was formerly on the boundary of the Flathead Indian Reservation. A few years ago each Indian was allotted a certain amount of land, and the remainder of the reservation was thrown open to settlement. On this summit and in the descent on the farther side the road runs through the pine forest that formerly covered much of the country, but it soon emerges into the broad, flat Jocko Valley, in which there are some fairly good farms. At milepost 16 an excellent distant view can be obtained of the terminal moraine which once marked the extremity of a small glacier that descended from the canyon in the range to the right. The plan of the moraine can not be seen from the train, but close inspection would show that the ridge of rocky fragments comes down from the canyon wall on one side and loops around and unites with the wall on the opposite side of the creek. As can be seen from the train, the moraine is built up to a height of about 100 feet. The mountains on the right (east), though not so high as the Mission Range, which can be seen farther on, are steep and rugged, towering above the valley to the height of several thousand feet. 
Arlee is one of the towns that have begun to grow since the reservation was thrown open to white settlers. It lies in Arlee. a broad valley containing rich agricultural land and Elevation 3,094 feet. St. Paul 1,276 miles. will doubtless in time become an important farming center. A familiar scene in this valley is shown in Plate XIX, $A$ (p. 119).

Just below Arlee faint beach lines can be seen on the right (east) near the base of the hill, and a short distance farther on a terrace of fine light-colored sediment is prominent on the same side of the road. This terrace can be followed with the eye as far as the canyon by which the river escapes from the valley. It is composed of brownish clay and sand and is supposed by some to be the sediment deposited at the bottom of Lake Missoula, or it may have been deposited by the present stream when it was ponded by a greater volume of water flowing down Flathead River from the melting glaciers to the north.

The broad valley in which the railway is situated is surrounded on all sides by rocky walls, through one of which the stream draining the valley has cut a deep gorge. Such a basin is seldom, if ever, produced in the normal development of a stream, but is common in the mountainous part of Montana. It is supposed to have been formed by the depression of the bottom of the basin, thus leaving the walls standing high above the valley floor. ${ }^{1}$

The rocks exposed in the walls of the canyon belong to the Belt series and consist largely of quartzite and argillite. In many protected places in the canyon the white sand and clay deposited by the flooded Flathead River can be seen, showing that this body of water filled not only the valleys where they are wide, but also the narrow canyons connecting them.

At Ravalli the valley is narrow, but the hills are smooth and comparatively low. A stage line runs from this place north 30 miles to Polson, at the lower end of Flathead Lake, where

\section{Ravalli.}

Flevation 2,714 feet. St. Paul 1,286 miles.

Reservation. Much of the best land for agriculture lies across the connection is made with boats for Kalispell and other towns on the Great Northern Railway. Ravalli is the distributing point for a large part of the Flathead
${ }^{1} \mathrm{It}$ is possible to account for the formation of the basin in this manner, but how did the stream cut the canyon at the outlet? There are three possible answers to this question. (1) The movement of deformation was so slow that the stream cut the rock faster than it was uplifted. (2) The basin was formed so rapidly that the water was ponded, forming a lake. This lake rose until the water flowed over the rim, and the stream thus formed cut the present gorge, permitting the water to escape. (3) The valley was filled with sediment, and the stream draining it simply cut down through the soft material and trenched the barrier of hard rock below. During this period the stream removed the great bulk of sediment with which the basin had been filled. Which of these explanations fits the case in hand can not be told without a detailed study of the region, but each process should have left certain marks, if it has occurred, and it is through the study of these characteristic marks that the question can be answered. 
ridge north of the station and extends from St. Ignatius to Flathead Lake. A large part of this area is to be irrigated by the United States Reclamation Service. ${ }^{1}$

St. Ignatius, 4 or 5 miles northeast of Ravalli, is one of the Catholic missions early established in this region. ${ }^{2}$ It was originally located farther down Clark Fork, but in 1854 was removed by Father Hoecken to its present position, on a fertile plain at the foot of the Mission Range, which affords an abundant supply of good water for household use and for irrigation.

Half a mile north of Ravalli is the southeast corner of the Montana National Bison Range, which is surrounded by a specially woven wire fence that can be seen for several miles north of the track. The range, which is under the management of the Biological Survey of the United States Department of Agriculture, includes both prairie and mountains and is over 30 square miles in extent. The buffalo herd now numbers 75 , besides which there are a few antelope, deer, and other large game animals.

Just beyond Ravalli, at milepost 31 , the traveler can obtain a charming view of the rugged tops of the Mission Range on the right (northeast). This view includes the highest peaks of the range and is the most nearly alpine scenery to be found along the Northern Pacific Railway in the Rocky Mountains.

${ }^{1}$ Nestling between the towering peaks of two ranges of the Rocky Mountains, the Flathead Indian Reservation occupies one of the world's most beautiful valleys. A few years ago the allotment of land to the Indians was completed, and the remaining agricultural lands were opened to white settlement and nearly all filed on.

The Reclamation Service is building an irrigation system to cover about 150,000 acres of land in this region. The average elevation is 3,000 feet above sea level, and the temperature ranges from $30^{\circ}$ below zero to $100^{\circ}$ above zero. The soil is clay, gravelly loam, and forest loam, and fair crops of hay, grain, and fruits are frequently produced on it without irrigation, the average annual rainfall being about 16 inches. With irrigation, alfalfa, all kinds of grain, vegetables, and fruits in great variety suited to this elevation and latitude are produced in abundance.

The Indians are allowed to sell a portion of their allotments, and farms may also be purchased from white settlers at fair prices. The lands bordering Flathead Lake, which has more than 50 miles of shore line within the reservation, have been subdivided by the Government into summer-resort tracts of $2 \frac{1}{2}$ to 5 acres, and many of these tracts have been sold.

This valley undoubtedly has a great future as a residential section. It is located near the south end of Glacier National Park, between two great transcontinental railway lines. In summer the valley is gay with flowers. The mountain slopes are covered with fir, larch, and pine trees; the glaciers on their summits sparkle in the sunshine, and at their bases lakes of emerald and sapphire delight the eye and provide the angler with his favorite sport.

2 The first Catholic mission in this region was established in 1841 at $\mathrm{St}$. Marys, in Bitterroot Valley. The next was the Cour d'Alene mission, founded in 1842 in the Corur d'Alene Valley, some 100 miles to the west. St. Mary's mission suffered severely from the raids of the Blackfeet Indians, and in 1850 the property was sold and the mission abandoned. The next mission to be established was that at St. Ignatius. 
The terraces of soft material, resting against slopes composed of the Belt series, show almost continuously along the valley of Jocko River, first on one side and then on the other, growing Dixon.

Elevation 2,531 feet. St. Paul 1,293 miles. stronger downstream. They reach their best development at Dixon, where the Jocko joins Flathead River, which comes down from the north. This river drains Flathead Lake, which lies 26 miles to the north and is one of the largest bodies of fresh water lying wholly within the United States. The river is navigable for small steamers from Dixon up to a point within a short distance of the lake, where rapids stop further progress.

At Dixon the material deposited in Lake Missoula is fine white sand and clay, being the "rock flour," or fine rock powder, which a glacier grinds from its rocky bed and which is carried off by the streams, giving them a milky appearance. It was brought down by Flathead River from the immense glacier that long ago occupied the entire valley of Flathead Lake and the country farther north, where the town of Kalispell now stands. This material was deposited in the waters of the lake in thin layers (laminæ) that give to the cut edges of the material a banded appearance. It is probable that the glacier occupying Flathead Valley reached at its greatest extension nearly or quite to the place now occupied by the town of Dixon, but there is no evidence that it passed farther down the valley.

At milepost 40 a more extended view than that obtained farther up the valley can be had of the Mission Range, including its highest summit, McDonald Peak, and a small glacier lying in a deep amphitheater on the north face of the peak, where the ice is sheltered from the rays of the midday sun. This is the only glacier in the Rocky Mountains that can be seen from the Northern Pacific trains. (See Pl. XIX, $B$, p. 119.) This noble range marks the eastern boundary of the Flathead Reservation and is the western limit of a broad wilderness of mountain ranges that extend to the margin of the Great Plains and include farther north the rugged mountains of the Glacier National Park. The Mission Range was named from the Roman Catholic mission established at St. Ignatius, near its base, in the early fifties. The range can be seen by the traveler from a point a little west of Dixon to McDonald, and if the weather is clear the view can be relied on to hold the attention, especially from early in October until late in June, when the rugged outlines of the range are veiled under a shining cover of snow. The nearest peaks are about 24 miles away and rise to heights of a little more than 10,000 feet above sea level, or about 7,500 feet above the railway.

This chain of mountains lies on the east border of the broad grassy plains of the Flathead Valley and extends in a remarkably straight line due north and south for nearly 60 miles. The straightness of the mountain front and the sheer abruptness of its rise to heights of 
7,000 feet above the low, flat plains at its base make a topographic contrast that is rarely equaled in any other part of the Rockies. This remarkably abrupt front is due to the mountain range being a single huge block of the earth's crust raised and tilted to the east and broken away from the block underlying the lowlands of the Flathead Valley, the unusually straight front of the mountains corresponding closely with the plane along which this break took place.

The hills on both 'sides of the railway are made up of rocks of the Belt series, which show little variety in the different beds of which it is composed or in the positions in which they lie. The valley walls are generally dark, and they are fringed on one side or the other by remnants of the lake terrace, which can always be identified by their light color.

In the lower part of the valley, between Dixon and Paradise, the railway follows the banks of the river for several miles, and the traveler can obtain many attractive views of the broad river and its wooded islands, set off by the dark background of the rugged hills.

Near Perma the river turns to the left and cuts a narrow canyon through the ridge which above this place bounds the valley on the left. In this part of its course the Belt series is cut by many dikes and sheets of igneous rock (diorite), showing that at one time there was considerable disturbance in the region. The most prominent of these igneous sheets shows in a bold hill on the north side of the river, nearly opposite milepost 50. The igneous material was intruded between the layers of the sedimentary rocks, which subsequently have been turned on edge, and the diorite now forms a conspicuous outcrop for a number of miles to the north.

At Perma another sill of the same sort as that described above crosses the river almost at the station, making a loop through the

Perma.

Elevation 2,512 feet. St. Paul 1,306 miles. cliffs immediately to the left and then crossing the river about $1 \frac{1}{2}$ miles farther west. This loop is caused by the folding of the sheet of igneous rock, together with the inclosing sedimentary beds, into a great anticline, but the bedding is so obscure that the fold can not be traced from the train.

Twenty miles to the north is Camas Hot Springs, a small settlement where bath houses and hotels are maintained for the use of summer visitor's who wish to bathe in the warm mineral water.

Below Perma the canyon is deep and narrow, and its walls are very precipitous. Just beyond milepost 55 the railway crosses to the north side of Flathead River, at a point where several diorite sills are conspicuously exposed. From this point to Paradise the valley has high, rocky walls that rise 1,500 to 2,500 feet above the valley floor. The rocks are dark brownish red, but the large masses of broken rock below the cliffs are a much brighter red and give to the valley the appearance of being decorated with great red banners that are caught up at the base of the cliffs and stream down to the 
valley bottom in long, graceful curves. The walls are rugged and picturesque, but there is little or no variety, and one soon tires of watching the selfsame combination of river, talus slopes, and cliffs. The river, however, is really worth attention and presents many charming views of the clear water, almost turquoise-blue, sweeping around willow-covered islands and between the stately pines that dot the river's bank. (See Pl. XX.) The terrace of soft material doubtless once continued throughout the canyon, for here and there can be seen remnants of the white clay that vary the monotonous red of the valley walls.

At milepost 62 Flathead River unites with Clark Fork, sometimes called Hell Gate or Missoula River. The low-grade line of the railway, Paradise.

Elevation 2,499 feot. St. Paul 1,319 miles. which leaves the main line at De Smet, follows the winding course of Clark Fork and at Paradise, a short distance below this milepost, connects with the main line. Paradise is a district terminal and so becomes the stopping place of many of the freight crews. The traveler, like others who have gone over this road before him, may wonder for what reason the name Paradise was given to this narrow, rugged valley. The writer has no suggestions to offer, except that even this valley may have looked like a paradise to some unfortunate individual who had been obliged to cross the adjacent mountain country, or who had perchance been lost in the intricate mazes of its deeply cut ravines.

At Paradise the change is made from Mountain to Pacific time, one hour earlier.

The valley of Clark Fork between Paradise and Plains has about the same character as that of Flathead River above Paradise. "The rocks are similar, belonging to one of the oldest sedimentary formations known in this country (Prichard). The low terrace which is so conspicuous at Dixon and which is there composed largely of fine material scoured from the bedrock by the glacier that came down Flathead Valley still persists below Paradise, or, rather, remnants of it can be seen here and there on both sides of the valley; but the material is pink, partaking more of the color of the local rocks and in places containing gravel beds of considerable thickness.

To the traveler interested in the geologic history of this region some of the most instructive features of the topography are small deltas or terraces in the side gulches at a height of fully 400 feet above the level of the track. A typical example can be seen on the right (north) just beyond milepost 1. Evidently these deltas mark the mouths of small streams that at one time flowed into a lake whose surface was at the level of the terrace. The lake must have been very transient to have left no other evidence of its existence, and probably it was merely a low stage of the body of water called glacial Lake Missoula. 


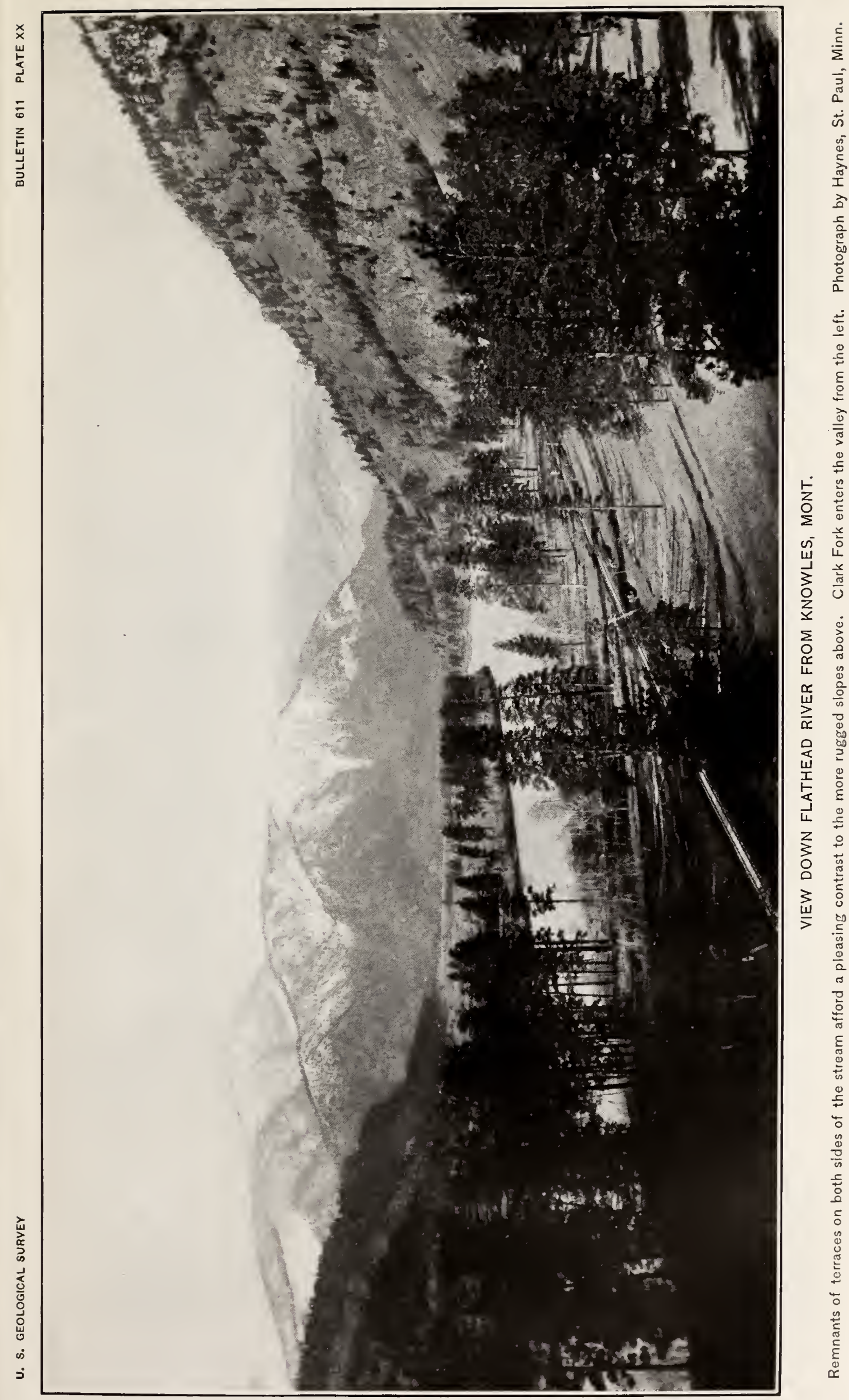







Plains, formerly known as Horse Plains because it is situated in the midst of a broad prairie that was used as a pasture ground for

\section{Plains.}

Elevation 2,482 feet. Population 481 .

St. Paul 1,325 miles. horses belonging to the trading posts of the Hudson's Bay Co., is a sort of oasis in the desert of rocky canyons along Clark Fork. Here the valley opens and terraces are well developed, especially one about 170 feet above river level. East of the station the terrace shows on the north, but west of the town a large remnant of the terrace, equally well developed, can be seen across the river on the south.

Faint beach lines also appear on the high, smooth hill slope back of Plains, but it is probable that the lines visible from the railway are not the highest in this region, the others being obscured by the timber and brush growing on the higher hills.

One of the most striking features of the valley of Clark Fork is the fairly regular succession of narrow canyons and broad valleys, without any apparent reason so far as the action of the stream is concerned. These changes are not due to differences in the hardness of the rocks, for as a rule all the formations of the Belt series have about the same degree of resistance to erosion; but they are due to great breaks or faults in the rocks. These faults have broken the crust of the earth into huge blocks, some of which have been raised, some lowered, and some tilted over so that one edge is very much lower than the other. These dropped or tilted blocks form the broad valleys, and the raised blocks or the upper edges of the tilted blocks have proved to be serious obstructions in the pathway of the river, which has succeeded in cutting only narrow canyons through them. This explains the broad valley at Plains and the narrow canyons which lie directly above and below that place.

The breaking into blocks and then the tilting of these blocks into various attitudes seem to have been the movements that gave to this region its distinguishing structural features. ${ }^{1}$ In some of

${ }^{1}$ East of the Mission Range the rocks are thrown into great folds or tilted along faults having a general northwesterly trend, but west of that range the structure is less regular and the folds and faults



directions. As a rule, the rocks are not very severely folded, and most of the faults are of the type called normal faults, due to tension or stretching of the earth's crust, but some of them are distinctly of

FIgURE 30.-Normal faults $(A)$ and overthrust fault $(B)$. Arrows indicate direction of movement.

do not have a common direction, as they do farther east. In the area about Plains the structure is broadly simple and yet is rendered complex in detail by minor faults and folds that trend in different the overthrust type, due to horizontal stresses of compression. The two kinds of faults are illustrated in figure 30 .

In a normal fault the rocks slip in such a way that they occupy a greater hori- 
these blocks, as, for example, the one which lies between Plains and Thompson Falls (see sheet 20, p. 152), the rocks are slightly bent into broad, open folds. The structure in this block is represented by figure 31 .

The rocks in sight east of Plains belong to the Prichard formation, which dips to the west and passes below water level, and at Plains the thin-bedded gray quartzite and argillite of the overlying (Ravalli) formation come into view. This formation continues with f iirly regular dip to a point about one-half mile beyond Weeksville. At this place the Newland limestone, overlying the Ravalli, appears, dipping in the same direction and at about the same angle as the

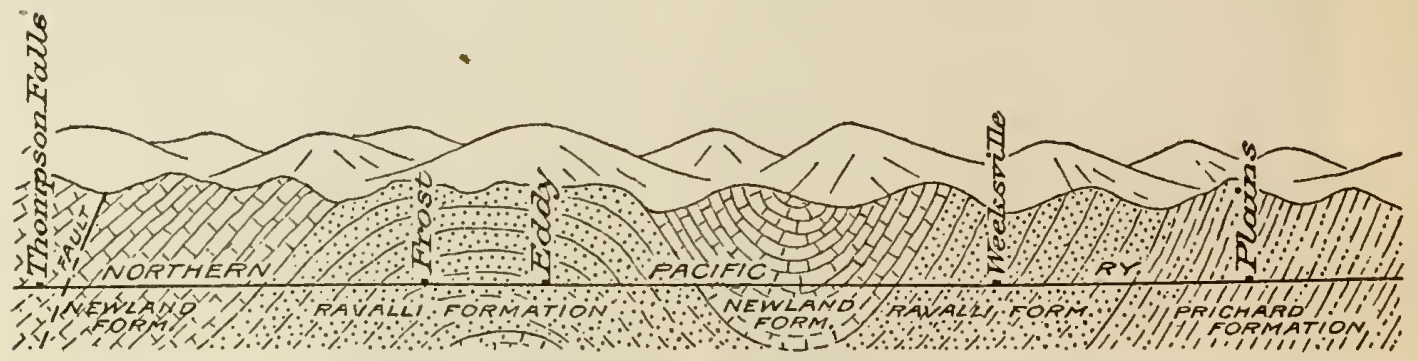

Figure 31.-Great folds in the rocks between Plains and Thompson Falls, Mont.

Ravalli. Within a short distance the dip flattens, and at milepost 15 is reached the point toward which the beds dip from both directions; that is, the axis of the syncline. The beds here are nearly horizontal, but toward the west they begin to rise, and near milepost 18 the Newland limestone disappears from track level, though still present in the tops of the hills, and the Ravalli Eddy.

Elevation 2,437 feet. St. Paul 1,340 miles. formation beneath it again comes into view. From this place past Eddy and Frost to the mouth of Thompson River, near milepost 26, the cliffs are made up of Ravalli rocks thrown into folds or wrinkles too small to be shown in the diagram (fig. 31). The walls in this part of the canyon are probably more rugged and more nearly vertical than those of any other part of its course.

Beyond Thompson River the dip of the rocks brings the outcrop of the Newland limestone down from the tops of the hills (see fig. 31),

zontal space after the movement than they did before the faulting occurred, as shown by the diagram. An overthrust fault is generally produced by the breaking of a fold. The fold and fault are due to compression in the earth's crust, and the result of the movement is that the older rocks are shoved upward and forward over the younger rocks, thus giving them an inverted relationship. Another result is that the faulted mass occupies less space than it did before the movement began.
In the region west of Missoula there have probably been two principal movements-(1) a movement of compression, which threw the rocks into broad folds, the compression in some places, as in the Glacier National Park, being so intense as to produce a great overthrust fault; and (2) a movement of tension or stretching, by which the somewhat folded mass of rock was broken by a great many normal faults, a few of which are shown on the accompanying maps. 

but at this place it extends for only a mile or so and is cut off by a fault that trends about $\mathrm{N} .20^{\circ} \mathrm{W}$. and crosses the railway near milepost 29. As shown on the map, this fault separates the Newland limestone on the east from the Ravalli quartzite on the west.

On approaching Thompson Falls the traveler can see on his right a hill, and, if his eyesight is particularly good, he may be able to detect on its summit a steel tower erected by the United States Forest Service. On this tower during the summer is stationed an observer, who with powerful glasses watches for forest fires. As he can see on all sides for a distance of 50 miles, if the weather is clear, he is generally able to detect a fire soon after it starts and to notify the nearest ranger by telephone. Forest fires, especially such as swept through these mountains in 1910, not only burn a great amount of valuable timber but may also destroy towns along their pathway, with considerable loss of lifo. Under the present system of observers on high stations and an efficient organization for fighting fire, the destruction of timber has been greatly reduced and the loss of life nearly eliminated.

The town of Thompson Falls took its name from the falls of the same name, which were discovered in 1809 by David Thompson, the explorer and astronomer of the Northwest Fur Co.

Thompson Falls. The water here falls 50 or 60 feet over resistant ledges Elevation 2,458 feet. of the Ravalli formation. It is estimated that with Population 325 .

St. Paul 1,351 miles. proper installation 40,000 horsepower could be generated at this fall. A dam is now being constructed, and electric power is to be furnished to the mountain division of the Chicago, Milwaukee \& St. Paul Railway, 35 miles to the south. It is reported that any surplus power may be utilized in a similar manner by the Northern Pacific Railway.

West of Thompson Falls the.bluffs on the right recede so far from the river that the rocks composing them are unrecognizable from the train, but the Ravalli formation ${ }^{1}$ shows at railway level dipping

1 The northern Rocky Mountains are made up largely and in some places wholly of the formations constituting the Belt series. These formations consist of sandstone, shale, and limestone, but the limestone is generally a small part of the entire mass. The sandstone is in many places changed to quartzite and the shale to argillite (a hard, slaty shale). These rocks were first studied in detail by C. D. Walcott in the Belt Mountains, east of Helena, Mont., and honce are known as the Belt series.
Very few fossils occur in the series, and those that have been found bear very little resemblance to the Cambrian faunas with which they should be most closely related. The only traces of animal life so far discovered in the sandstones and argillites are a few fragments of a small crustacean and the trails of worms. The limestones are crowded with peculiar corallike forms, which Walcott has recently. determined to be fossil alga similar to the algæe now growing in some of the lakes of New York. Walcott concludes from $40063^{\circ}-$ Bull. $611-16-10$ 
toward the west, and across the river the Newland limestone is present in the tops of the hills. This formation appears to be flat, but that is because the traveler is looking at the edge of beds that dip directly away from him. This relation of limestone and quartzite to the river and railway holds in a general way from Thompson Falls to Noxon.

At Kildee, near milepost 37, the railway crosses the river, and from this point to "Trout Creek there are two lines; the "high line" keeps up on the bench away from the river and the "low line" runs near the stream. The latter affords many interesting views of the river, which flows in a gorge cut a hundred feet or so in the floor of the old broad valley.

a study of the fossils mentioned that the large region in Montana, Idaho, and Alberta, Canada, underlain by the Belt series was during their deposition a continental area on which the sediments were deposited by rivers or in shallow lakes. The appearance of the rocks confirms this view, for all of them, even including many of the thick beds of limestone, are ripple marked, showing that they were deposited in shallow water. In places the argillite contains mud cracks and prints of raindrops, which could have been made only when the soft material was above water level and exposed to the drying effect of the atmosphere or the beating of the storm. By piecing together measurements made in several places, it is estimated that the Belt series, so far as it has been seen, is from 25,000 to 30,000 feet thick; but the base has not yet been found, and its real thickness may not be very much greater.

In this great mass of material certain parts, on account of their composition and association with other beds, can readily be separated and identified in the areas in which they have been studied; but other parts have no characteristics by which they can readily be distinguished, and consequently different workers have classified them in different ways.

The two units most easily identified are the Newland limestone, which Walcott first recognized in the Belt Mountains, and the Helena limestone, which he named from its occurrence at the capital of the State. The general section along the Northern Pacific Railway, ac- cording to F. C. Calkins and J. T. Pardee, is as follows:

Formations composing the Belt series along the Northern Pacific Railway.

Helena: Limestone, dark blue or

Thickness in feet.

gray, weathering buff....... 2,400

Empire: Shale, greenish gray, or quartzite.................

Spokane: Shale or argillite, with some sandstone, all deep red... 1,500 Greyson (Striped Peak): Shale, dark gray or green, with some white quartzite............... Newland: Limestone, blue, thin bedded, but with some heavybedded buff layers. ........... Ravalli: Quartzite, with some dark bluish or greenish shale.. Prichard: Shale, dark bluish, interbedded with sandstone; base not exposed............... 8, 800

The rocks of the Belt series occur along the Northern Pacific Railway from the Bridger Mountains on the east to Sandpoint on the west. In the eastern part of this area they form the core of most of the mountain ranges, but west of Bonita they are the only hard rocks to bo seen, with the exception of a few intrusive masses, to Pend Oreille Lake. They form the mountains of Glacier National Park and extend along the Rocky Mountains from the southern boundary of Montana, south of Butte, far into Canada, covering a territory about 500 miles long by 200 miles wide at the widest place. 
This part of the valley of Clark Fork was not scen by Lewis and Clark, but it was discovered soon afterward by the agents of the various fur companies, then exceedingly active in exploring new territory, and later it was examined in detail by the Government engineers. ${ }^{1}$

${ }^{1}$ Soon after the return of Lewis and Clark the adventurous agents and explorers of the fur companies were engaged in examining every valley in the Northwest for fur-bearing animals and selecting sites for trading posts on almost every navigable stream and lake. Most of these advance guards of white civilization kept no record of their wanderings, but two of them, Alexander Henry and David Thompson, connected with the Northwest Fur Co., left excellent notes of their explorations and their dealings with the Indians in the northern United States and southern Canada in the early years of the nineteenth century. Alexander Henry was a fur trader with only one ambition, to further the interests of the Northwest Fur Co.; but David Thompson was an astronomer and scientific explorer, and his notes afforded much more accurate data regarding the character of the country and the location of important places than those of almost any other man who traversed this region in the early days. The territory covered by these men was largely the same, but Thompson explored the region about Clark Fork and Pend Oreille Lake, while Henry was engaged in trade with the Indians at the head of the Columbia.

In 1806 Thompson descended Kootenai River to about the place where the present Idaho-Montana line crossed that stream and proceeded southward along an old Indian trail across the Cabinet Mountains to Pend Oreille Lake. He reached the outlet of Clark Fork into Pend Oreille Lake September 9 and built a trading post on the point just north of it. This post he called Kullyspell House, from the name of an Indian tribe. In the modified form of Kalispell this name is now applied to a thriving town on the Great Northern Railway, near the north end of Flathead Lake. So far as known, this was the first visit of a white man to Pend Oreille Lake and Clark Fork. From Kullyspell House Thompson ex- plored the valley down past Sandpoint as far as Priest Rapids and up Clark Fork and Flathead River to Dixon, where the Flathead reaches the railway from the north. On one of these trips up the river he established another trading post near the falls that were subsequently named in honor of their discoverer. This post he called Saleesh House, from the native name for the Flathead Indians. After the establishment of these trading posts Thompson continued westward to the Columbia, and he was the first white man to pass down that stream from the mouth of Priest River to Pasco, where the Northern Pacific Railway now crosses the river.

Although the fur traders explored the valley of Clark Fork as early as 1806, their reports were made only to the officials of the companies, who had no interest in promoting settlement, and consequently the public had little information concerning this interesting region until it was examined by the Government engineers who in 1853-54 explored it thoroughly to find the best route for a Pacific railroad. In 1853 Lieut. R. Saxton passed this way on his route from the Pacific coast to the headquarters of the expedition in the Bitterroot Valley. Saxton proceeded up Columbia River and across country to Pend Oreille Lake, which he reached August 12. He found that, owing to the high, steep mountains, it was impossible to pass around the south end of the lake, and he had considerable difficulty in skirting the north end, where Hope is now situated. He then proceeded up Clark Fork, but he found the route very rough and difficult, for the stream in many places swung so close to the bluffs as to make it necessary for the party to find a way over the rough mountain sides. After passing Thompson Falls and ascending Flathead River to the site of Dixon, he went up the Jocko and crossed the summit at the head of the Coriacan Defile to St. Mary (Stevensville), in Bitterroot Valley. 
The railway, from the point where it crosses Clark Fork to Trout Creek, follows the outcrop of the Ravalli formation, which dips to the left; and it is probable that the hills on the left are composed of the next higher formation, the Newland limestone, but they are so far distant and so nearly covered with trees that it is doubtful if the traveler will be able to distinguish formations.

Just beyond milepost 50 the train crosses Big Beaver Creek, a large stream joining the river from the south, and a little farther on Vermilion Creek enters from the other side. The valley of the Vermilion is particularly interesting, for at its mouth there is a marked delta, visible from the train on the high line, which is 320 feet above the present river level. This delta could have been built only when the valley of Clark Fork was filled with water up to that altitude, and it probably marks some stage-possibly a closing stage - of glacial Lake Missoula. The reason why the valley of Vermilion Creek contains a more pronounced feature of this kind than the adjacent tributary valleys is that it connects at its head by a low pass with a valley draining into Kootenai River to the north. Through this low pass a large stream evidently flowed from the north at some time in the remote past. At that time all the Kootenai Valley, the next valley to the north, which is followed by the Great Northern Railway, was filled with an ice sheet that came down from the north, blocking all the previously existing watercourses and discharging at least part of its waters through the valley of Vermilion Creek. The sand and gravel carried by this stream were dumped into Lake Missoula when it stood 320 feet above the present level of Clark Fork. This was doubtless only a temporary outlet, else more material would have been brought down, possibly enough to completely fill the valley of Clark Fork.

At Trout Creek the hills on the south are composed of the Newland limestone, which dips toward the river at an angle of $40^{\circ}$. It is

\section{Trout Creek.}

Elevation 2,374 feet. St. Paul 1,372 miles.

valley as far as Noxon.

A short distance beyond Trout Creek the river makes a decided bend to the left and swings against the bluffs on that side. The railway follows the river and at milepost 59 is close to the mountain side, which is nearly bare, having been swept clean of trees in the great forest fires of 1910 . On one of these smooth slopes horizontal beach lines are visible. They can be identified up the slopes to a height of 1,200 feet above the river, or 3,500 feet above sea level, but beyond that height no trace of such markings has been found. The 
uppermost beach line here probably corresponds with the highest one observed near Missoula and Dixon and, as these beach lines were formed by the same body of water and therefore must have been horizontal, it is almost certain that the crust of the earth has been tilted since the disappearance of the lake, the surface about Missoula having been raised 1,000 feet above that at Trout Creek, as explained on page 134 .

Just beyond milepost 59 the roadway is cut in the base of a high cliff which is composed of Newland limastone lying nearly horizontal. The argillites and quartzites showing across the river and in the pyramidal island in the stream are vertical, hence there must be a fault between them which coincides in a general way with the course of the river.

Near milepost 67 a charming view is to be had of the cliffs on the south, which stand like a huge castle with battlemented walls.

The Newland limestone is exposed almost continuously along the river from milepost 59 to Noxon and for some miles beyond. It is

Noxon. generally horizontal or dips slightly to the northwest.

Flevation 2,187 feet. Nearly opposite milepost 74 Bull River joins Clark St. Paul 1,388 miles.

Fork from the north. This tributary valley is connected by a broad, deep trench directly through the Cabinet Mountains with the valley of Lake Creek, affording in glacial time a direct outlet for the great mass of ice that kept crowding down from the northern country. In this great trench the ice at its maximum was at least 2,000 feet deep. As soon as it emerged into the more open valley of Clark Fork it was reinforced by a large ice tongue that came down by Sandpoint and deployed up the Clark Fork valley. These two masses blended and filled the valley from Pend Oreille Lake to Noxon, forming an effective barrier across the pathway of the stream. Behind this barrier the body of water known as glacial Lake Missoula accumulated. In its passage up the valley the glacier left abundant evidence of its presence and work by the scouring which the valley received, the scratches on the rocks, and the bowlders of granite and other crystalline rocks which it carried into this area. The bowlders were not only dropped upon the valley floor, but many of them were left stranded on the valley wall up to a height of at least 2,000 feet above the stream.

Beyond Bull River there is little of interest for some distance. The valley walls are composed of Newland limestone,

Heron, Mont.

Elevation 2,267 feet. St. Paul 1,398 miles. cated by a signboard.

which dips gently downstream. Just beyond milepost 87 , a fow miles west of Heron, the train crosses the State line into Idaho, the boundary being indi- 
To those who remember Idaho in their school geographies as a small pink block, shaped like an easy chair facing east, it may be of interest that this State, which in 1890 added the forty-

Idaho. fifth star to the constellation on the flag, is nearly as large as Pennsylvania and Ohio combined and larger than the six New England States with Maryland included for good measure. It is divided into 33 counties, the smallest of which is half as large as the State of Rhode Island and the largest exceeds the combined area of Massachusetts and Delaware.

Idaho covers an area of 83,888 square miles, divided principally between the Rocky Mountain region and the Columbia Plateau, only a small part, in the southeast corner of the State, lying in the Great Basin. In elevation above sea level the State ranges from 735 feet, at Lewiston, to 12,078 feet at the summit of Hyndman Peak. It is drained by the Columbia mainly through Snake River and its tributaries, and has an annual rainfall of about 17 inches, the range in a single year at different places being from 6 to 38 inches.

The industries of the State are chiefly agriculture, stock raising, and mining. Hay, wheat, oats, and potatoes are the principal crops. A large area is cultivated by irrigation. The mineral production includes gold, silver, copper, lead, and zinc. The output of lead in 1913 was valued at $\$ 13,986,366$, that of silver at $\$ 6,033,473$.

The population of Idaho in 1910 was 325,924 .

A short distance west of the Idaho line the Newland limestone, which has formed the walls of the valley for the last 10 or 12 miles, dips below water level, and the quartzites of the Cabinet, Idaho. overlying formation (Striped Peak) appear. These Elevation 2,173 feet. rocks are so much harder than the limestone that Population 161.* St. Paul 1,404 miles. the river has succeeded in cutting through them only a narrow, tortuous passageway known as Cabinet Gorge (Pl. XXI, p. 143). The river pours its whole volume through a crooked defile not over 100 feet wide, and it is estimated that 40,000 horsepower could be developed here with the natural flow of the stream. The gorge is soon passed, so that those who wish to see it should keep a close watch on the right as soon as they cross the State line. Beyond Cabinet station as far as milepost 91 there are many cuts in bright-red and green argillite and thin beds of sandstone (Striped Peak formation) overlying the Newland limestone. These mark the middle of a broad, flat syncline, which crosses the river in a north-south direction. Farther west the rocks dip upstream, and at the railway bridge the top of the Newland limestone may be seen on the north bank of the river. 
The village of Clark Fork is situated at the head of the delta which Clark Fork has built where it enters Pend Oreille Lake. Below the village the track winds about in the broad plain of

Clark Fork.

Elevation 2,094 feet. Population 492.* St. Paul 1,412 miles. the river bottom, skirting shallow bays and swamps and winding among rocky islands that rise here and there in the delta plain. The rocks are limestone (Newland), dipping up the stream toward the axis of the syncline, but about 2 miles from the village the whole of the limestone has risen above water level, and the underlying red argillites and quartzites (Ravalli) are exposed in the cuts.

West of milepost 97 the traveler may get glimpses here and there of Pend Oreille Lake, but it is not until the train approaches Hope that an unobstructed view may be obtained. If it

Hope.

Elevation 2,087 feet. Population 215.

St. Paul 1,421 miles. is a clear day, the waters ripple in the sunshine against a dark background of rugged mountains, but if the air is hazy the lake seems to disappear in the distance between misty walls that rise on either side. One can but wonder what lies beyond that rocky gateway and long to board the little steamer lying at the dock and explore its remotest reaches. The broad expanse of water along the north shore is broken by several wooded, rocky islands that add greatly to the charm of the picture.

The French term pend (pendant) d'oreille means literally earring and was doubtless given to this lake by the early French explorers on account of its peculiar shape; but some authorities say that the name was originally given to a tribe of Indians because of their custom of wearing earrings and then was applied to the lake because these Indians inhabited its shores.

The lake is about 50 miles long and from 2 to 15 miles wide, and it is said to be very deep. As it is long and narrow and lies between mountains 2,000 to 3,000 feet high, it must, if the reported depth of water is correct, occupy a canyon rivaling in size and depth the Grand Canyon of the Colorado, in Arizona.

On the shore of the lake, near the place where Hope now stands, were once the main trails that led into the Kootenai country to the north. Over these trails supplies for the mining camps and goods for trade with the Indians were taken in and cargoes of precious furs brought out, but the traffic has ceased and the trails have become impassable. Hope is built on the side of a mountain so steep that its streets occupy levels 300 feet apart. It is important now as the site of a large sawmill and as a port for the small traffic on the lake.

The rocks back of Hope belong to the Prichard formation, which extends for about 7 miles, but they are cut by many dikes of granite similar to the great mass west of Sandpoint. The rocks also show 
greater metamorphism (changes due to pressure or to heat) toward this mass of granite, and on this account do not bear a close resemblance to those of the same age farther east.

Beyond milepost 111, west of Oden (see sheet 21, p. 160), the valley between the Cabinet Range on the east and the Selkirk Range on the west is a broad plain. Down this great valley a glacier once forced its way from Canada past Bonners Ferry and extended many miles south along the route followed by the Northern Pacific to Spokane.

On approaching Sandpoint the railroad skirts the extreme west end of Pend Oreille Lake, but in this part of the lake the shores are

\section{Sandpoint.}

Elevation 2,096 feet. Population 2,993.

St. Paul 1,437 miles. generally low, and the view is not so striking as that obtained from Hope. From Sandpoint the mountain slope on the opposite (south) side of the outlet of the lake, by reason of its gentleness and smoothness, is so different from those generally seen along Clark Fork, although composed of the same kind of rock, that it calls for an explanation. This long ridge does not rise abruptly from the water level at its north end, like the mountain slopes on the other side of

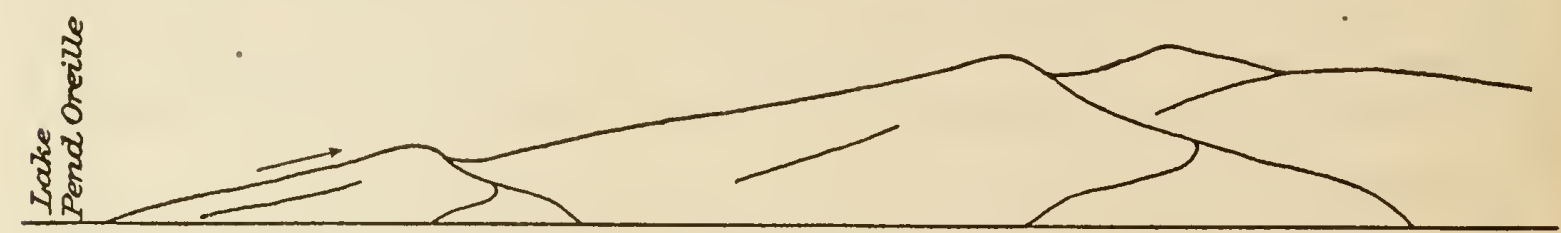

FIGURE 32,- Profile of mountain slope east of Sandpoint, Idaho. Ice moved in the direction indicated by the arrow and scoured the slope smooth.

the lake, but rises gradually to a height of 2,000 feet above the lake. The profile as seen from Sandpoint is represented in figure 32. The explanation of the gentle slope is that the great glacier which once came down the valley from the north and which probably had a depth of more than 1,000 feet, passed far up on the slope of this mountain and possibly completely overrode it. This mass of ice, with its embedded rocky fragments, ground off all irregularities of the mountain side, leaving it a gently inclined slope from bottom to top. The direction of the moving ice is indicated on the diagram by the arrow.

At Sandpoint the Great Northern and the Spokane \& International (Canadian Pacific) railways approach the Northern Pacific, but the Great Northern at its point of nearest approach is 2 miles from the lake and can not be seen from the train.

South of Sandpoint the railway crosses the lower end of Pend Oreille Lake on a steel and concrete viaduct 4,769 feet long. From this viaduct may be obtained, if the day is clear, a comprehensive view of the mountains east of Pend Oreille Lake. The significant feature of this mountain mass' is not its height or its ruggedness, 




GEOLOGIC AND TOPOGRAPHIC MAP OF THE

\section{NORTHERN PACIFIC ROUTE}

From St. Paul, Minnesota, to Seattle. Washington

Base compiled from United States Geological Survey Atlas Sheets, from railroad alignments and profiles supplied by the Northern Pacific Railway Company and from additional

UNITED STATES GEOLOGICAL SURVEY GEORGE OTIS SMITH, DIRECTOR

David White, Chief Geologis

R. B. Marshall. Chief Geographer

$$
1915
$$

Each cuadrangle shown on the map with a rame in parenthesis in the

lower lef: corner is maped in dorat
BULLETIN 611

SHEET No. 20

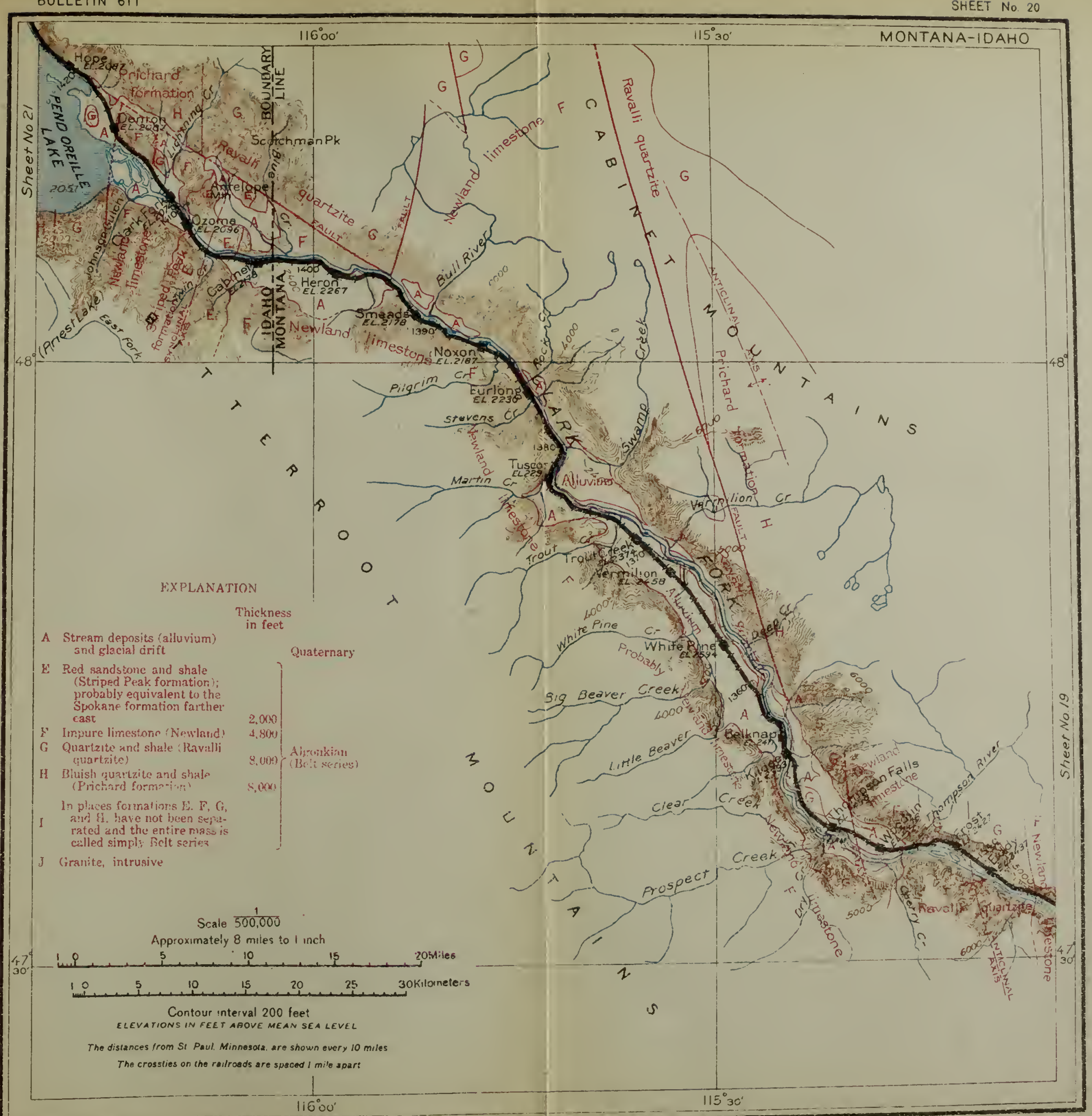



but the evenness of its summits, as if the region were a vast plateau. As this is the country through which the westbound traveler has just come, he appreciates that such is not the case, but the mountains are made up of ridges of nearly the same height, the tops of which, at a distance, blend so as to appear like a flat-topped mountain. The even crests of such ridges and mountains are supposed to have been formed when the land was low lying and in fact nearly a plain (a peneplain). ${ }^{1}$ At that time there were no mountains in this region and the surface was as flat as the prairies of North Dakota and probably much nearer sea level.

For some distance after crossing Pend Oreille Lake the railway skirts the base of the mountain on the left (east), and the cuts through the low spurs reveal the granite in many places. On some of these ledges, even from the moving train, glacial striæ (scratches in the bedrock made by rock fragments embedded in the ice and forced along under enormous pressure) may be seen. The direction of these scratches is parallel with the railway and shows that the glacier moved up the valley toward Spokane.

The railway crosses the valley, cutting through many knolls of gravel and sand deposited by a stream which flowed from the end of

1 The constant tendency of almost all natural processes going on at the surface of the earth is to wear away the high land and to reduce the continent toward sea level. As these processes are always at work wearing away the higher points of the land, it follows that in time the surface of the land would be reduced to a plain were there no counteracting forces at work. The forces that tend to interfere with the reduction of the surface of the earth are those that produce movement within the crust, for such movements are almost always accompanied by elevation at some point, and when this occurs the reduction process is of necessity begun anew and carried on all over again. If, however, crustal movements do not occur for a long time, the surface of the earth is reduced nearly to a plain that stands near but not at sea level. Such a surface has been named a peneplain (meaning "almost a plain"). In most regions the process of reduction in the past has been interrupted by the elevation of those particular parts of the crust before the surface was greatly reduced, but in certain places the proc:-

ess seems to have been carried nearly to its limit and a peneplain produced.

If after the formation of such a peneplain the land is uplifted evenly over a wide area, the peneplain, instead of being near sea level, will form an upland or plateau. As such an elevated tract is always vigorously attacked by streams, canyons will soon be cut back from the edge of the plateau or from the mouths of the streams, and, as time goes on, these canyons will reach farther and farther back into the upland and new canyons will be established, until finally all the even surface of the peneplain will be cut away and instead of a plain or peneplain it will be a hilly upland or a mountainous belt, its character depending on the amount of the uplift. Despite the fact that the region has lost its even surface, the hills or mountains will have, for a long time, about the same height, and their summits will be but little below the surface of the old peneplain. In other words, the country is a dissected plateau, but to an observer at a distance the even crest lines of the ridges still appear like the level top of the plateau. 
the glacier during the retreat of the ice from its farthest southward extension. Near milepost 24 can be seen on the west a slope of massive granite that has been laid bare by the ice and has been smoothed and rounded by the same agent. Such bosses of rounded rock have been called by the French "roches moutonnées" (sheepback rocks), and this term has now come into common use in this country.

All the indications thus far observed point clearly to the occupation of this valley by the ice. The small lakes which abound in the district afford still further evidence of the presence of a Cocolalla.

Elevation 2,228 feet. Population 278.* St. Paul 1,450 miles. glacier and the consequent rearrangement of all the drainage lines. Cocolalla Lake occupies a depression hemmed in by hills of gravel that was deposited by the ice or by water flowing directly from the front of the glacier. South of Cocolalla the valley is more or less swampy (another indication of a recently established drainage system), and. the granite lies on the west. Farther south the granite can be seen on the east side of the track, hence it probably underlies most of the valley; but, if so, it is well concealed in places by glacial drift.

The village of Granite is appropriately named, for the granite is well exposed there. A short distance beyond the station the railway

\section{Granite.}

Elevation 2,269 feet. Population 401.* St. Paul 1,458 miles. crosses a high bridge over what appears to be a deep, irregular channel scoured out by the ice, and the knobs of granite, scored and rounded, rise about it in all directions. After passing through a small tunnel in this rock, the train emerges into an open driftcovered plain strewn with bowlders of granite broken from the ledges near the tunnel and carried southward by the ice. Many of these bowlders are 20 feet in diameter, and they occur along the track for a distance of 7 miles from the village of Granite.

Although there are many lakes in this general region, they can not be seen from the train for the reason that they are near the margins of the hills, whereas the railway keeps the middle of the valley. From a point near Athol there appears to be an opening in the mountain wall which bounds the valley on the east. In this break lies the upper or south end of Pend Oreille Lake. The lake is easy of access from this direction and small steamboats will take one to almost any place along its shores. Spirit Lake lies on the west side of the valley, and a little farther south is Fish Lake. The largest lakes, Pend Oreille, Hayden, and Cœur d'Alene, are on the east and south sides of the valley. All these bodies of water have resulted apparently from the damming of the lateral valleys by sand and gravel brought down by the glacier 
The Spokane International Railway approaches the Northern Pacific line on the right near milepost 43 , runs parallel with it for some Athol.

Elevation 2400 feet Orist Population 281. st. Paul 1,465 miles. scrubby pine and it was not supposed to be suitable for agricultural or horticultural pursuits, but in recent years fruit trees have been successfully grown, and now apple orchards stretch along the railway for many miles. Although the valley is continuous, there is a constriction near Lone Mountain and a division of the drainage. The water north of this place finds its way into the Columbia by way of Clark Fork, whereas that to the south reaches the same trunk stream through Spokane River. Near milepost 51 Lone Mountain is a conspicuous object on the right (west). It rises to a height of about 1,000 feet above the plain. To judge from the bare rocks exposed about its base, the ice has abraded its foot, but whether or not the glacier passed over its summit is an open question.

At Ramsey, a station directly south of Lone Mountain, the railway is double tracked, the eastbound track diverging to the left,

Ramsey.

Elevation 2,340 feet. St. Paul 1,472 miles. to unite again with the westbound track at Rathdrum, the next station to the west. In going westward the train gradually approaches the mountain mass on the right, and at Rathdrum it is only a few hundred feet from the foot of the hill. Here the rock is a schist, 1 but whether the schist is of Archean age and therefore older than the

\section{Rathdrum.}

Elevation 2,212 feet. Population 725. St. Paul 1,478 miles.

Belt series, or whether it is the Belt, or some younger formation greatly changed, is a question that has not been settled. At Rathdrum the Northern Pacific crosses over a new line-the Idaho \& Washington Northern Railway. West of the crossing the railway runs near the hills on the north for a long distance, but on the left it overlooks the valley of Spokane River, which is spread out like a map before the eyes of the traveler. Most of the valley bottom is farming land, but some of it is too gravelly to be Hauser, Idaho. of much value for agriculture. The valley is par$\begin{array}{ll}\text { Elevation 2,140 feet. } & \text { ticularly beautiful as seen from a point a little west of } \\ \text { Population } 382 . * & \text { Hauser }\end{array}$ St. Paul 1,485 miles.

Hauser. From Hauser a branch line runs to Post Falls and Cœur d'Alene, at the foot of Cœur d'Alene Lake, and there is steamboat service on the lake and railway connection

${ }^{1}$ Schist is a rock in which a parallel or foliated structure has been developed by shearing or by pressure, a process generally accompanied by more or less recrystallization of the material composing it in layers parallel to the cleavage. Schists may have been originally sedimentary or igneous rocks, but if the schistosity is well developed the original character of the rock is generally obliterated. 
from its upper end to the Cour d'Alene mining district, ${ }^{1}$ described below by F. L. Ransome, and thence across the mountains to Missoula.

Between mileposts 66 and 67 the railway crosses the line between the States of Idaho and Washington, the exact point being indicated by a sign at the roadside.

The State of Washington has a land area of 66,836 square miles. It was admitted to the Union in 1889. In 1910 it had a population of $1,141,990$. Owing to its position on the coast, the Washington. first settlement in what is now Washington was made at a comparatively early date. The places to be occupied first were the posts of the Hudson's Bay Co. Of these Fort Vancouver, on Columbia River, established in 1824, was the headquarters; and Forts Walla Walla and Nisqually were outlying posts to the east and north, respectively.

1 The Cœur d'Alene district, whose mines yield about one-third of the lead produced in the United States, and supply, by value, about 85 por cent of Idaho's annual output of metals, lies high on the western slope of that northward prolongation of the Bitterroot Range which is sometimes called the Cœur d'Alene Mountains. It is to turn the flank of this lofty barrier that the main line of the Northern Pacific swings northwestward down the valley of Clark Fork and then westward by Pend Oreille Lake.

From the east the district is served by a branch of the Northern Pacific which leaves the main line at De Smet (change at Missoula) and, following the old Mullan wagon road, crosses the range by a high pass at the head of St. Regis River. From Spokane, on the west, the traveler may choose an all-rail route via the OregonWashington Railroad \& Navigation Co.'s line around the south end of Cœur d'Alene Lake, or he may proceed by one of three railway lines to the town of Cœur d'Alene, at the north end of the lake, and there embark on a steamer which connects at Harrison with the trains of the OregonWashington Railroad \& Navigation Co.'s line to Wallace, in the heart of the district.

Were it not for the mines, the Cœur d'Alene district would be nearly as complete a wilderness now as when Mullan constructed his road across the mountains 56 years ago. It contains almost no arable land, and the timber, while good enough for mining purposes, would probably not have been sufficient inducement to bring railways into the region. Mining is the one paramount industry of the district, and upon it all others depend. Approximately 5,000 men are employed in the mines and concentrating works, and the total population of the district is estimated at 12,000 .

Wallace, the principal town and the seat of Shoshone County, contains 3,000 people and is situated at the confluence of Canyon and Ninemile creeks with the South Fork of Cœur d'Alene River. This situation and the fact that it is the terminus of the Oregon-Washington Railroad \& Navigation Co.'s line from the west and the Cœur d'Alene branch of the Northern Pacific Railway from the east make it the chief distributing point of supplies for the district.

Although the Mullan road passed through what is now the most productive part of the district, 20 years elapsed before anyone realized that the steep, thickly forested hillsides visible from the road concealed great deposits of leadsilver ore. It was not until 1884 that attention was called to the mineral resources of the region by the exploitation of the gold-bearing gravel and quartz veins on Prichard Creek, in the northern part of the district. Discovery of the lead-silver veins on the South Fork of Cœur d'Alene River soon followed, and by 1888 these had overshadowed the gold 
For a number of years the hunting and trapping of fur-bearing animals was the chief occupation, but gradually the forest was cleared away and farms established. From the necessity of getting rid of the heavy forest developed the lumber business, which from the earliest settlement down to the present time has been the leading, industry of the State. In 1909 the value of the timber and lumber products was $\$ 89,000,000$.

Agriculture at first flourished only along the Sound, west of the Cascade Mountains, where rain is abundant; and the eastern, semiarid part of the State was utilized only for the grazing of cattle, horses, and sheep. Recently much of the land in the Yakima and Wenatchee valleys and along the Columbia has been reclaimed by the construction of irrigation works, and now it is renowned the world

deposits in productiveness and value. Since 1903 the district has produced considerable copper and of late years increasing quantities of zinc.

The production of Shoshone County (which is practically that of the Cour d'Alene district) for 1913 was as follows: Gold, \$81,749; silver, $9,337,109$ fine ounces; copper, 5,097,894 pounds; lead, $296,740,946$ pounds; and zinc, $21,415,565$ pounds, valued in all at $\$ 20,767,410$. The total value of all the metals produced in the district since mining began is approximately $\$ 262,608,000$.

The mines that have been most productive of lead-silver ore during the past few years are the Bunker Hill and Sullivan, Morming, Hercules, Last Chance, Senator Stewart, Standard-Mammoth, and Hecla. The Tiger-Poorman, at Burke, once a large producer, has been worked out. The Standard-Mammoth is also nearly exhausted, but a continuation of the ore body has been found in the adjoining Greenhill-Cleveland mine. The one large copper mine of the district, the Snowstorm, has yielded ore of the gross value of about $\$ 11,000,000$.

The rocks in which the Cour d'Alene ores are found belong to the Belt series. These beds in the Cour d'Alene district have been crumpled into folds and have been intruded by masses of molten material (magma) which, on cooling, solidified as a granitic rock known as quartz monzonite. During or after the solidification of the igneous rock the region was trav- ersed by great cracks or fissures along some of which took place movements amounting to thousands of feet, producing what the geologist terms faults. In other places, where the disturbance was less, hot solutions, probably connected with the intrusion of the granitic rock, deposited the ores, partly as fillings of open cracks but largely as replacements of the adjacent rock by chemical processes. After the intrusion of the granite and the formation of the deposits of ore, an uneven layer of rock, probably some thousands of feet in thickness, was gradually removed by the action of weather and streams. This erosion exposed the once deeply buried granite and the ore.

The principal mineral of the lead-silver ores is galena (sulphide of lead) which in this district invariably contains some silver. Other common minerals of metallic luster associated with the galena are pyrite (sulphide of iron), pyrrhotite (magnetic sulphide of iron), chalcopyrite (sulphicle of copper and iron), and sphalerite (sulphide of zinc). The characteristic waste mineral of nonmetallic luster associated with galena, that is, the gangue of the ore, is siderite (carbonate of iron).

The ores, as mined, carry, as a rule, from 5 to 50 per cent of lead and from 3 to 45 ounces of silver to the ton. All but the highest grades are concentrated in the district, by milling, to a product containing about 50 per cent of lead and from 15 to 55 ounces of silver to the ton. 
over for the quality of the apples produced. In many districts fruit raising has been carried to the extreme, and now there is a tendency to the greater cultivation of alfalfa and grains. One of the most interesting features of the agricultural development of Washington has been the transformation of the lava plateaus of the central and eastern parts of the State into great fields of wheat that stretch for miles without a break. The success of dry farming in this region made Washington one of the great wheat-raising States of the country. In 1909 its yield of wheat was worth $\$ 35,000,000$, and its forage crops $\$ 17,000,000$.

Washington produces yearly metals valued at $\$ 1,000,000$, but the chief mining industry has been and still is the mining of coal. Coal was first mined in 1860 in Whatcom County, and a little later near Issaquah, in King County, but shipment to San Francisco did not begin until 1871. Since that time many mines in several fields have been developed, and the industry of mining grew rapidly until it reached its maximum in 1910. It declined then because Washington coal came into direct competition with the fuel oil of California. It is estimated that in 1913 fuel oil replaced 5,000,000 tons of coal in the markets tributary to Puget Sound. The value of the coal mined in Washington in 1913 was $\$ 9,243,137$.

The products of the State are valued about as follows: Manufactured products (1909), $\$ 220,000,000$; agricultural products (1909), $\$ 103,000,000$; mining products (1913), $\$ 17,000,000$.

Beyond the State line the railway continues along the north side of the valley, but the valley is not so wide as it is farther east. Apple orchards are numerous and in places extend along the track for miles without a break.

Near milepost 76 the hills on the right (north), which are in plain view, take on a different aspect, and a close inspection shows that they are capped by a flat-lying mass of dark rock. This is the Yakima basalt, one of the principal lava sheets of the great Columbia River basalt which, together with that of nearly the same age in the Snake River valley of Idaho, constitutes one of the most extensive lava plains in the world. The lava flooded all of central and southern Washington and large areas in Oregon and Idaho, and the traveler will see little else in the way of hard rocks from Spokane to the east foot of the Cascade Mountains. It flowed against the mountains on the east, and fiery streams extended up the valleys heading in this range. Although some of the lava lies east of Cœur d'Alene Lake, it is uncertain how far it went in the Spokane Valley, for it has been covered by the glacial gravel. The exposure just noted is the first to be seen by a traveler coming from the east. 
Between mileposts 77 and 78, west of Irvin, the railway crosses Spokane River, the water of which is so beautifully clear that every object on the bottom is plainly visible. Near this point the military road constructed by Lieut. Mullan crossed Spokane River. This road entered the main valley from the southwest, east of the present city of Spokane, and then extended up the valley to Cœur d'Alene Lake.

West of the railway bridge the surface of the country to the south is littered with large bowlders composed of many kinds of hard rock, which the ice brought down from the north. From their abundance it is supposed that these bowlders mark the point of greatest advance of the ice and are in the nature of a terminal moraine, although no distinct ridge or other characteristic topographic feature has been left in the valley, as is usual at the extremity of a glacier.

Although the basalt covers most of the country in this vicinity, it did not engulf all the hills, for the highest knob on the north, Little Baldy, composed of schist, stood above the molten flood that rolled into this region from the west. The low hills on the left are composed wholly of basalt, which also shows near the river in the outskirts of the city of Spokane. Here it can be seen at close range as the train passes through the deep cuts on its way to the station. ${ }^{1}$

'Spokane River has been beset by
many difficulties in carving its present
channel. At the time the great flood of
lava inundated the region, there was
evidently a deep valley here which was
flooded with the molten material. This
inundation did not come as one great
wave, but doubtless flood succeeded
lood with fairly long intervals between
until the lava was piled up to a great
thickness, nearly obliterating the orig-
inal channels.

When the outpourings of lava ceased, the water found an outlet in part along the old courses, but in most localities the eruptions changed the face of the entire country, so that the streams were compelled to carve for themselves new valleys in the hardened lava. This process was well along when the great glacier, laden with the rocky fragments it had plucked from the valley walls, swept down the valley. The materials carried by the glacier were distributed by the streams flowing from the ice front and scattered over the entire valley, filling it to the height seen to-day. Thus for the second time the stream was obstructed and its valley greatly modified, but with the disappearance of the ice it again set to work to carve a valley suitable for a stream of its size. Work was begun near its mouth, but gradually its gorge has been extended upstream until the fall, which marks the point where active cutting is in progress, has reached its present position in the city of Spokane. Here the river makes a series of plunges over precipitous slopes of basalt. Originally this formed a beautiful fall as the swirling waters broke against the dark rocks in their downward plunges, but now the stream has been obstructed for the third time by a dam, and the water has been diverted by man for the production of power. The beauty of the falls is gone forever, for in seasons of drought there is scarcely a trickle where once the river leaped and boiled in its mad rush over the jagged rock. To-day the water drives great turbines that generate 30,000 horsepower for municipal uses and for operating mines and mills in the Cour d'Alene district. 
Spokane (spo-kan') is a division terminal of the Northern Pacific Railway, and is the center of an extensive agricultural and mining region that is frequently referred to as the "inland Spokane, Wash. empire of the West." A settlement was early estabElevation 1,919 reet. lished at this place, and in 1881 it was incorporated Population 104,402. St. Paul 1,505 miles. as Spokane Falls, but later the second part of the name was dropped. The city is served by main lines or branches of all the transcontinental railroads crossing the States of Washington and Oregon, including the Canadian Pacific. Fort Wright, one of the more modern military posts of the Government, is attractively situated on the bluffs of the river just below the city limits, but is not visible from the train.

On leaving the station at Spokane (see sheet 22, p. 164) the train runs down the broad valley for some distance, but not within sight of the falls, and then turns to the left up the valley of Latah Creek. Here there are extensive hillside cuts on the left, exposing beds of dark sand and gravel, which were evidently derived largely from the basalt and were washed into this side ravine by floods that came down the main valley. This is evident from the way in which the gravel is bedded. ${ }^{1}$

The valley of Latah Creek, as well as that of Lake Creek, up which the railway goes, is marked by a number of well-developed terraces that were doubtless formed at the same time as or soon after the formation of the delta described above, and a correct interpretation of their meaning would throw much light on the conditions prevailing

\footnotetext{
${ }^{1}$ Careful inspection shows that the sand and gravel is cross-bedded and that the cross-bedded layers dip to the south, up Latah Creek. Figure 33 represents the edges of the beds as they are exposed in the side of the cut. This sandy material

top of the bed $A$ and laid down as a thin layer on the sloping surface $A B$. This action was continued until the basin of the side stream was filled to the line $A C$. The main stream was then deprived of this dumping ground, for that was filled

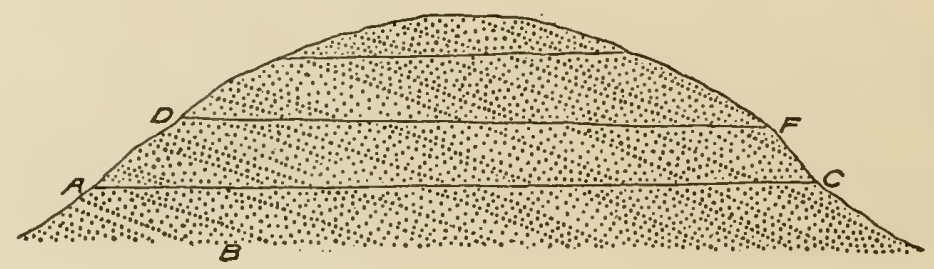

Figure 33.-Cross-bedding in glacial gravel on Latah Creek 1 mile west of Spokane, Wash.

was deposited as a delta-that is, the material was washed into the side valley, then occupied by a lake, and at first was laid down on the slope $A B$. The point $A$ marks the surface of the water, above which the material could not be piled. Additional material was carried along the

to the same height as the river channel, so the gravel was dropped in the main valley, building it up to the height of $D$. $\Lambda t$ this new height the process was repeated until the side valley was filled to the line $D F$ and eventually to the highest point the water reached.
} 




GEOLOGIC AND TOPOGRAPHIC MAP OF THE

NORTHERN PACIFIC ROUTE

From St. Paul, Minnesota, to Seattle, Washington

Base compiled from United States Geological Survey Atlas

Sheew, from railroad alignments and profiles supplied by

information coliected with the asistance of this company

UNITED STATES GEOLOGICAL SURVEY GEORGE OTIS SMITH. DIRECTOR

David White. Chief Geologist R. B. Marshall, Chief Geographer 1915

Each quadrangle slown on the map with a name in parenthesis in the lower left corner
Sheet of that name

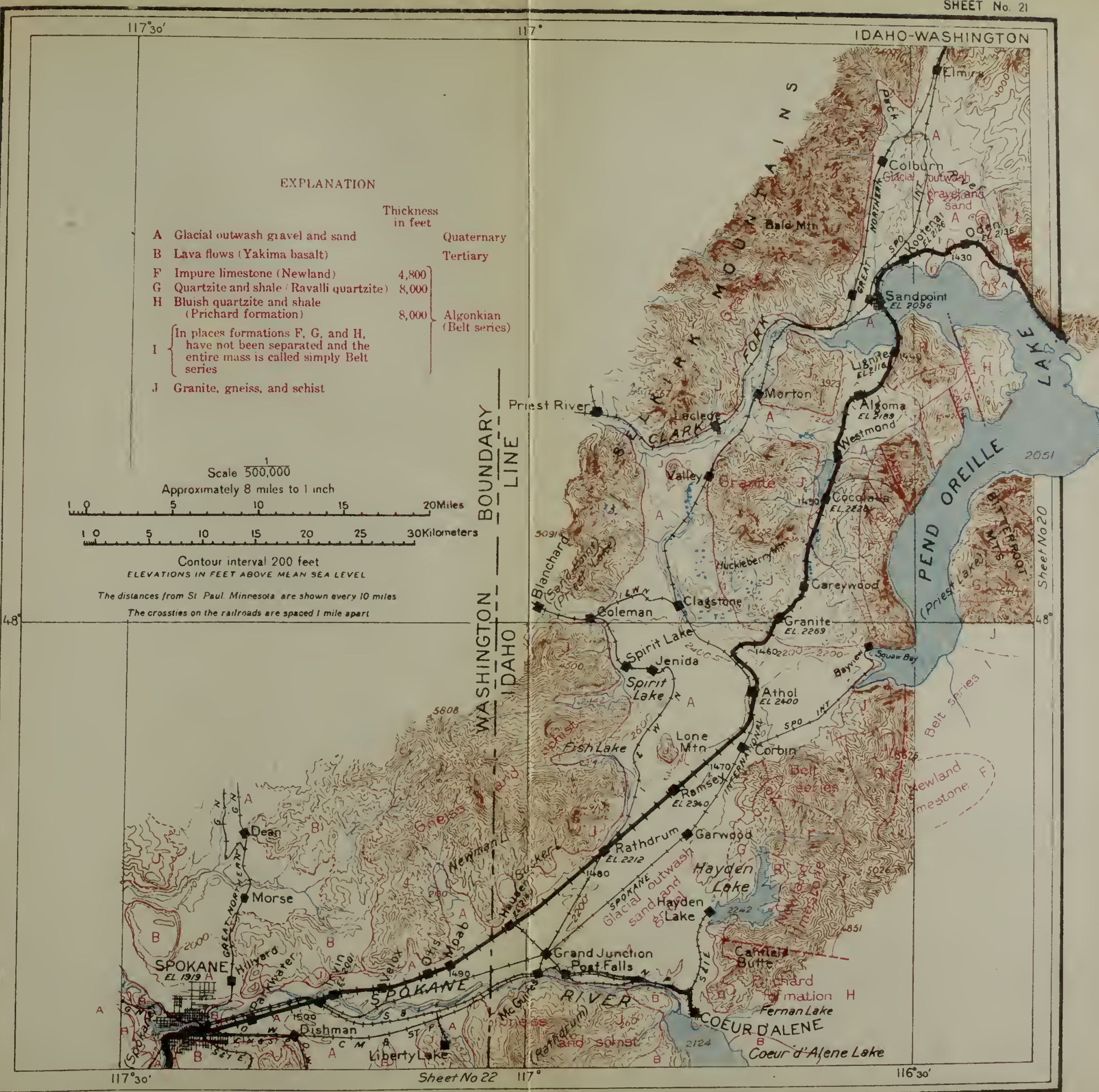



at that time, but unfortunately no one has studied them carefully enough to read their history in detail.

The bedrock on all sides is the basalt, which consists either of hard, dense rock that represents the interior of a lava flow or the more scoriaceous material of the upper part caused by the expansion of steam. ${ }^{1}$

Although the flows of lava were very extensive, either the molten material did not completely engulf the hills composed of older rocks, or the lava that buried them has since been removed, uncovering the schist at the surface over small areas. Such an area can be seen on the left (east) just before reaching Marshall (see fig. 34), and there are other areas farther on. The schist is easily distinguishable by its light color. Such occurrences of old rocks in the midst of the flood of lava are found only near the mar-



FIGURE 34.-Island of gneiss or schist in the lava (Yakima basalt) near Marshall, Wash. gins of the lava plain, where the depth of the once molten material was never great or where the underlying surface was particularly hilly.

From Marshall a branch of the Northern Pacific runs southward to the Palouse country. Two other railways that run parallel with

Marshall.

Elevation 2,137 feet. Population 757.* St. Paul 1,514 miles. the Northern Pacific between Marshall and Spokane can be seen on the right. The nearer line is that of the Oregon-Washington Railroad \& Navigation Co. and the other is the Spokane, Portland \& Seattle Railway. Just beyond milepost 98 the Northern Pacific crosses both these lines and continues on their right to Cheney, the next station.

\footnotetext{
${ }^{1}$ Molten lava, as it issues from the earth, is always charged with steam. While the lava remains underground the steam can not escape, but when the lava reaches the surface the pressure is relieved and the steam expands and collects in bubbles, which rise to the surface and burst, giving off the clouds of vapor that always rise from a moving flow of lava. Many bubbles, however, can not escape, and they become, as it were, frozen in the upper part of the flow, giving it a vesicular or honeycombed appearance, as can be seen from the train in many places.

Columnar jointing, perpendicular to the cooling surfaces and therefore nearly vertical, is the most universal and striking structural feature of the basaltic flow. The columns vary greatly in size and regularity of form, their diameters ranging from a few inches to 6 feet. Cross sections of the most perfect prisms are as a rule pentagonal (five-sided) or hexagonal (six-sided), and polygons of four, seven, or eight sides are also common. Columns, such as those described above, may be seen in almost every good exposure of the hardened lava.
}

$$
\text { 40063-Bull. 611-16-11 }
$$


Near Cheney a branch line turns to the north and runs to Medical Lake and Coulee City, in the heart of the Big Bend country, so called because it lies inside of the great westward bend of Cheney. Columbia River. The two railways just mentioned Elevation 2,345 feet. lie only a short distance to the left, but beyond Population 1,207.

St. Paul 1,521 miles.

Cheney they bend to the east and can not be seen again from the Northern Pacific line, although they parallel this line to Columbia River near Pasco. Cheney is situated on the great lava plain of eastern Washington. Near the railway the traveler sees little but bare rock, but he can catch glimpses here and there of the low rolling hills that constitute the great wheat belt of this part of the State. The railway follows in a general way a slight depression in the surface, but the traveler may Tyler.

Elevation 2,301 feet. Population $421 *$. St. Paul 1,532 miles.

be surprised at riding over such a wide stretch of country without seeing any flowing creeks or even creek channels. In humid regions there is a creek channel in every valley. Even in the arid country of the Southwest there are established watercourses, which, though frequently or generally dry, take care of the occasional flood waters; but here there are only shallow irregular valleys, and no stream channels are to be seen. True there may be here and there, strung out in a more or less definite line, a series of shallow basins holding swamps or even shallow lakes, but these have no outlets above ground, and if they are connected at all the connection must be by an underground channel. It is evident that during most of the year there is little running water in this region, as the annual precipitation decreases from 18 inches at Spokane to 7 inches at Pasco. Most of this is absorbed by the soil,${ }^{1}$ and the remainder finds its way in to the open layers between the sheets of dense lava and reappears as springs in some neighboring canyon or coulee.

A possible explanation of the peculiar scouring of the surface rocks into basins without any definite stream channels is that it was done by ice. This subject is more fully considered in the footnote given on page 163 .

${ }^{1}$ F. C. Calkins states: "It [the soil] is so porous that rain or melted snow is quickly absorbed by it, so that a smaller proportion is lost by run-off or by evaporation from puddles than would be lost if it were more clayey and impervious, and, on the other hand, it is not loose enough to allow the water to sink rapidly and become unavailable, as it does in a deep sandy soil. The spaces between the particles of the fine loam are so small that the water is held in them by adhesion or capillary attraction and yields to the force of gravity only slowly and to a comparatively small extent.". Therefore a large proportion of the slight precipitation is kept sufficiently near the surface to be used by the growing wheat, and successful grain culture is possible with a rainfall that would be insufficient in a soil of less advantageous physical constitution. 
At Fishtrap there are a number of sniall hills on both sides of the track which appear, to one familiar with glacial topography, to be of

Fishtrap.

Elevation 2,282 feot. St. Paul 1, 536 miles. glacial origin. When examined closely they are found to be composed of light-colored clay or shale which is very different from the material deposited by ice. The peculiar hummocky form of the hills is due to the softness and fineness of the material composing them and to the peculiarities of erosion in a semiarid climate. Few if any watercourses are developed in the hills, hence they have no regular pattern or arrangement. The rains are infrequent, only a few gullies are established, and the development of such gullies tends to produce isolated conical mounds rather than low continuous ridges, such as would be produced in similar material in more humid regions.

As the material composing these hills is fine and evenly bedded, it was probably deposited in a body of standing water, and as its age, so far as the evidence has been obtained, corresponds in a general way to that of similar beds (Ellensburg formation) in the Yakima Valley, it is considered to be a part of that formation. The bulk of the sediment deposited in this great lake was dropped near shore in the vicinity of the Cascade Mountains, and only the finer material was carried as far east as Fishtrap. This was deposited over the basalt in a thin sheet, which has been largely removed, leaving isolated outliers like those described above. ${ }^{1}$

Near milepost 123 there is some rough country that shows on a small scale the effect of erosion on the sheets of basalt. In a more humid region most of the sharp edges of the tables would be rounded off and the slopes would be gentle and regular, but in a semiarid country each remnant of a lava sheet or other hard bed of rock stands up sharp and distinct as steps on the hillside or as isolated tables or mesas on a small scale. Thus the sheets of lava were not swept away

${ }^{1}$ Although there is litile doubt about the origin of the Fishtrap Hills, there is considerable uncertainty in the minds of geologists as to whether there has ever been an incursion of the northern glaciers into this region. The fact which leads to the belief that ice once occupied this country is the presence, far southwest of Spokane, of bowlders of granite and quartzite 12 to 20 inches in diameter. These bowlders are not numerous, but occasionally the traveler, if his sight is sufficiently acute, may catch glimpses of them, even from the swiftly moving train. Generally the presence of such bowlders is taken as a certain indication of the former occupation of the country by ice, but it has not yet been satisfactorily determined whether these bowlders were brought directly by the glacier and were dropped from its moving mass, whether they were floated along on cakes of ice in a large lake, or whether they were simply washed out over this plain from the ice front when it was in the vicinity of Spokane. If the bowlders here were as numerous and as large as the bowldere in North Dakota west of Missouri River there would probably be no question as to their glacial transportation, but in the State of Washington they are so few in number and are scattered over so wide an extent of country that some doubt naturally arises as to whether moving ice was the vehicle by which they were transported to their present resting places. 
layer by layer, as one peels an onion, but were cut through in many places, leaving rugged remnants here and there that make a distinct type of badland topography.

The railway descends into a pronounced valley and reaches the town of Sprague, named for Gen. J. W. Sprague,

\section{Sprague.}

Elevation 1,906 feet. Population 1,110. St. Paul 1,546 miles.

a former manager of the Pacific coast division. Railway shops formerly here have been removed and the town is now dependent on the dry farming of the adjacent uplands.

The train runs down the valley and at a distance of 3 miles from Sprague comes to the upper end of Colville Lake. This strip of water adds a pleasing variety to an otherwise rather monotonous landscape, but it lacks the picturesque setting of trees and mountains that give to the lakes farther east their charm and beauty. The railway curves in and out around the projecting spurs of basalt on the west shore to a point near the outlet of the lake and there turns more to the west and crosses the basaltic plateau.

Many bowlders of foreign material such as granite and quartzite may be observed near the south end of the lake and along the line westward at least as far as milepost 138, but it is doubtful if any can be found beyond that point.

Ritzville, the largest town between Spokane and Pasco, is the center of a rich agricultural district. This is a part of the great wheat belt of eastern Washington that has been so wonderfully Ritzville.

Elevation 1,822 feet. Population 1,855. St. Paul 1,570 miles. developed by dry-farming methods. About a mile beyond Ritzville a branch line turning to the right (west) and known as the Ellensburg cut-off has been graded and is said to be ready for the rails. When this line is completed it will not only open up a large area of farming land but also give a line to Ellensburg, west of Columbia River, 100 miles shorter than the present route. ${ }^{1}$

${ }^{1}$ The traveler may wonder why the Northern Pacific, having Puget Sound as its objective point, should bend so far to the south after leaving Spokane and then turn to the north after crossing Columbia River at Pasco. The first intention of the company was to build a line to Portland down Columbia River, as well as a line to Puget Sound across the Cascade Mountains, and a coast line connecting Portland and Puget Sound. At the time it was decided to recommence construction, in 1879, the Oregon Railway \& Navigation Co. had built a line from Portland up the south bank of CoIumbia River to Wallula, at the mouth of
Walla Walla River. In order to hasten construction of the main line of the Northern Pacific it was decided to utilize this line for the transportation of material for that part of the through line which lies east of Pasco and to postpone for a time the construction of the line along the north bank of Columbia River and that across the Cascade Mountains. Immediately after the main line was completed, in 1883, the construction of the line across the Cascade Mountains by way of the Yakima Valley was begun. The controlling reason for swinging the line so far to the south was to make the connection with the Oregon Railway \& Naviga- 

Beyond Ritzville are the stations Essig (see sheet 23, p. 168), Paha, and Ruby, but there is little of interest until, as the train descends a Lind. valley at milepost 164, the main line of the Chicago, Milwaukee \& St. Paul Railway is seen on the left. Elevation 1,364 feet. Population 831 . St. Paul 1,587 miles.

This road diverges from the main line of the Northern Pacific at De Smet, a short distance west of Missoula, and crosses the Cœur d'Alene Mountains by a more direct route than that of the Northern Pacific by Pend Oreille Lake. At Lind the two roads are on opposite sides of the valley, but a mile below the town the St. Paul road crosses the Northern Pacific on a substantial steel and concrete viaduct. Below the crossing the St. Paul line keeps down the valley, but the Northern Pacific climbs the slope beyond the creek so as to pass into another valley draining to the south. In ascending this ridge it is interesting to note that in a number of cuts where the rocks are well exposed the basalt is overlain by white silt or clay and fine sand that covers the entire hillside and conceals every irregularity of the hard rock beneath. This material has been taken as indicating the presence of a lake in glacial time, similar to glacial Lake Missoula, but the absence of lines of stratification (bedding) shows that the material has had a different origin. The question of the origin is bound up in the general Tertiary history of this region. ${ }^{1}$

After reaching the summit at Providence the railway begins the long descent of a little valley which leads eventually into the open plain above Pasco. This is one of the least interestProvidence.

Flevation 1,549 feet. St. Paul 1,595 miles.

ing stretches, so far as scenery is concerned, along the Northern Pacific, for the valley is so narrow that the views from the train give no idea of the character of the upland. The valley is carved in basalt, which shows in places in rugged ledges, with the white loess mantling everything.

tion Co.'s railroad, as stated above, but there were other reasons, such as the possibilities of obtaining large traffic in the Yakima Valley and the fact that any crossing of Columbia River above Pasco involved much heavier grades and more expensive construction than the present crossing. The construction of the line by the Northern Pacific along the north bank of Columbia River was delayed so long that Congress declared a forfeiture of that portion of its charter and of the accompanying land grant, and it was not until 1908 that a railroad was constructed along the north bank of the Columbia by the Spokane, Portland \& Seattle Railway
Co., a corporation owned jointly by the Northern Pacific and the Great Northern companies.

${ }^{1}$ The Tertiary history of Oregon and Washington begins before there was a Cascade Range, at a time when the territory now occupied by that range, as well as much of the region lying to the east, was a lowland in which shallow estuaries extended for long distances from the coast, while to the east were fresh-water lakes. In these shallow waters and on the low land near them was laid down a thick series of beds of shale, sandstone, and coal, now known as the Swauk and Roslyn formations, of Eocene (Tertiary) age. The 
Near milepost 192 a branch line of the road enters the valley from the right and gradually descends along the valley wall. This branch unites with the main line at Connell and serves to

Connell.

Elevation 845 feet. Population 778.*

St. Paul 1,615 miles. connect this place with Coulee City and the Big Bend country to the north.

Below Connell the valley walls grow more rugged, and at Cactus siding (milepost 200) a very prominent wall of lava is seen on both sides of the valley, but more particularly

deposition of these beds was interrupted by a flow of basaltic lava which was the beginning of a great series of flows that reached their maximum development in the succeeding Miocene epoch.

Sheet after sheet of basaltic lava was poured out over a territory 250,000 square miles in extent that included the greater part of Washington, all of eastern Oregon, part of California, and a large area in the Snake River valley of Idaho. (See map of Columbia River plateau on sheet 23.) It is probable, however, that the eruptions in the Washington area began at a somewhat earlier date than those of the Snake River plains of Idaho, which seem to have been in part contemporaneous with the last flows that occurred along Columbia River.

It is a generally accepted view that the molten rock was forced up through great cracks or fissures in the crust of the earth. This conclusion is based mainly on the following evidence: (1) The volume and extent of the lava floods are so enormous that it is diffirult to conceive of their eruption from ordinary craters; (2) the rarity of the fragmental materials known as tuffs, breccias, etc., indicates a welling up through fissures without the explosive action characteristic of crater eruptions; (3) old fissures through which the floods of lava came forth have been discovered-fissures now filled with the cooled and hardened basalt in observable connection with overlying sheets of lava.

The basalt was not poured forth in one great outburst, but is made up of a great number of layers or individual flows which in places are thousands of feet in agrgregate thickness. About 20 such flows are exposed in some of the bluffs of Colum- bia River. Each one represents a distinct outpouring of lava, the eruptions being separated by intervals of time, some of which must have endured for centuries, for they are marked by beds of soil in which trees grew to considerable size before being charred and buried by later flows. The eruptions of lava, especially in the later stages of activity, were separated also by periods in which other materials accumulated, consisting of volcanic ash and beds of sand, clay, and gravel laid down in lakes or rivers.

In addition to the massive flows that constitute the greater part of the formation there are beds of fragmental volcanic material, such as bombs and smaller angular fragments of lava. Such materials have either been thrown up to great heights and rained down upon the surrounding country, or, mixed with hot water, have flowed over the surface as mud. The fragmental materials are not so widely distributed as the massive flows.

The quantity of material poured out during this period was enormous. The greatest thickness of the lava and associated deposits is not less than 4,000 feet, but if it averages only 500 feet thick over the entire area, seemingly a very moderate estimate, it would make a mass of 24,000 cubic miles, or a cube nearly 30 miles in height. Even this great volume may be far less than that actually poured out.

Coincident with the later stages of the lava eruptions occurred a subsidence of the area east of the present Cascade Range, and a large lake was formed, in which accumulated material derived from the land area on the west. Before the basaltic eruptions had ceased a great volcanic disturbance occurred in the Cascade region and lava of another kind (andesite) was 


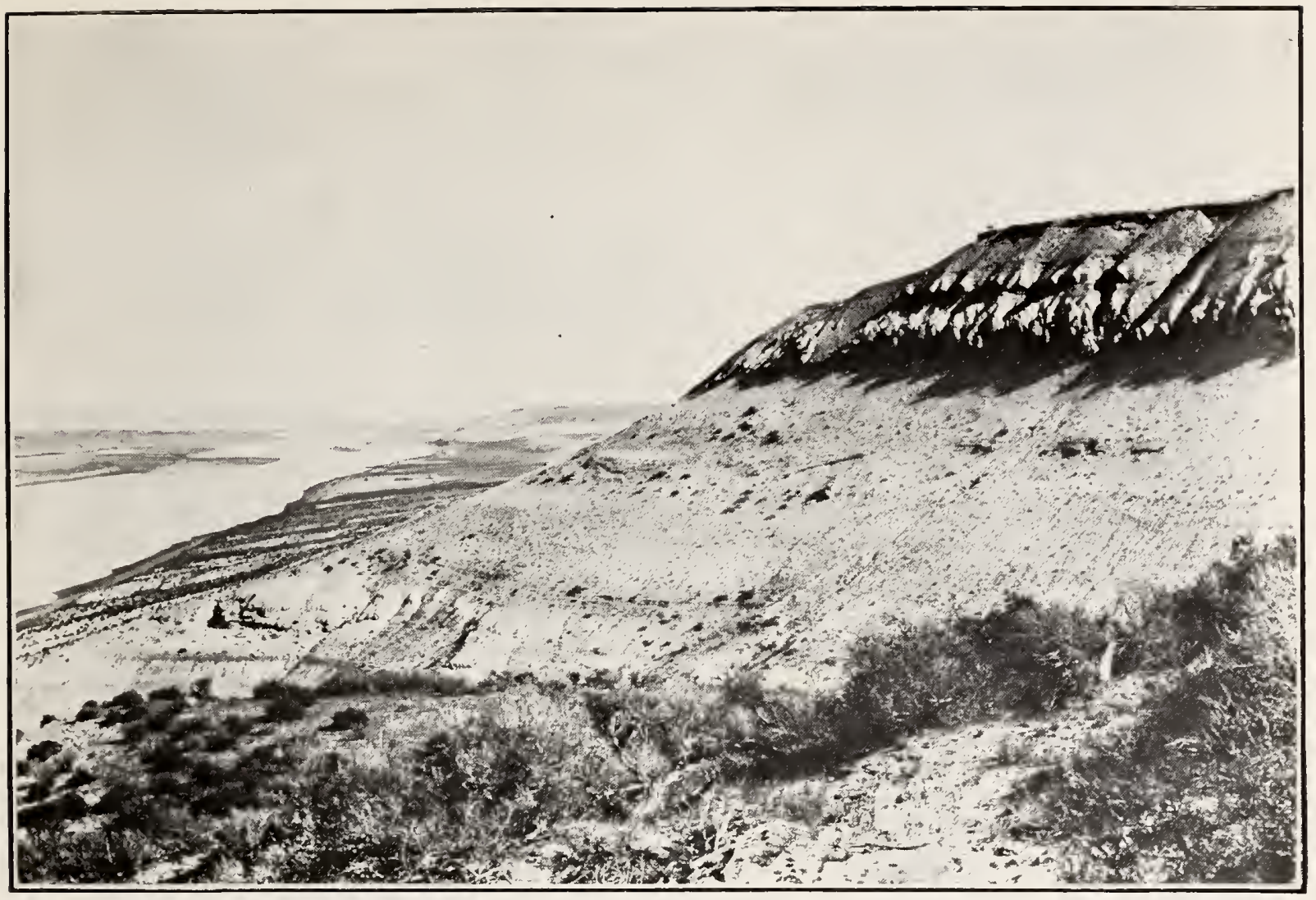

A. WHITE BLUfF OF THE COLUMBIA, 20 MILES ABOVE PASCO, WASH.

Composed of white volcanic ash (Ellensburg formation). Man on horseback on top of bluff indicates size of bluff.

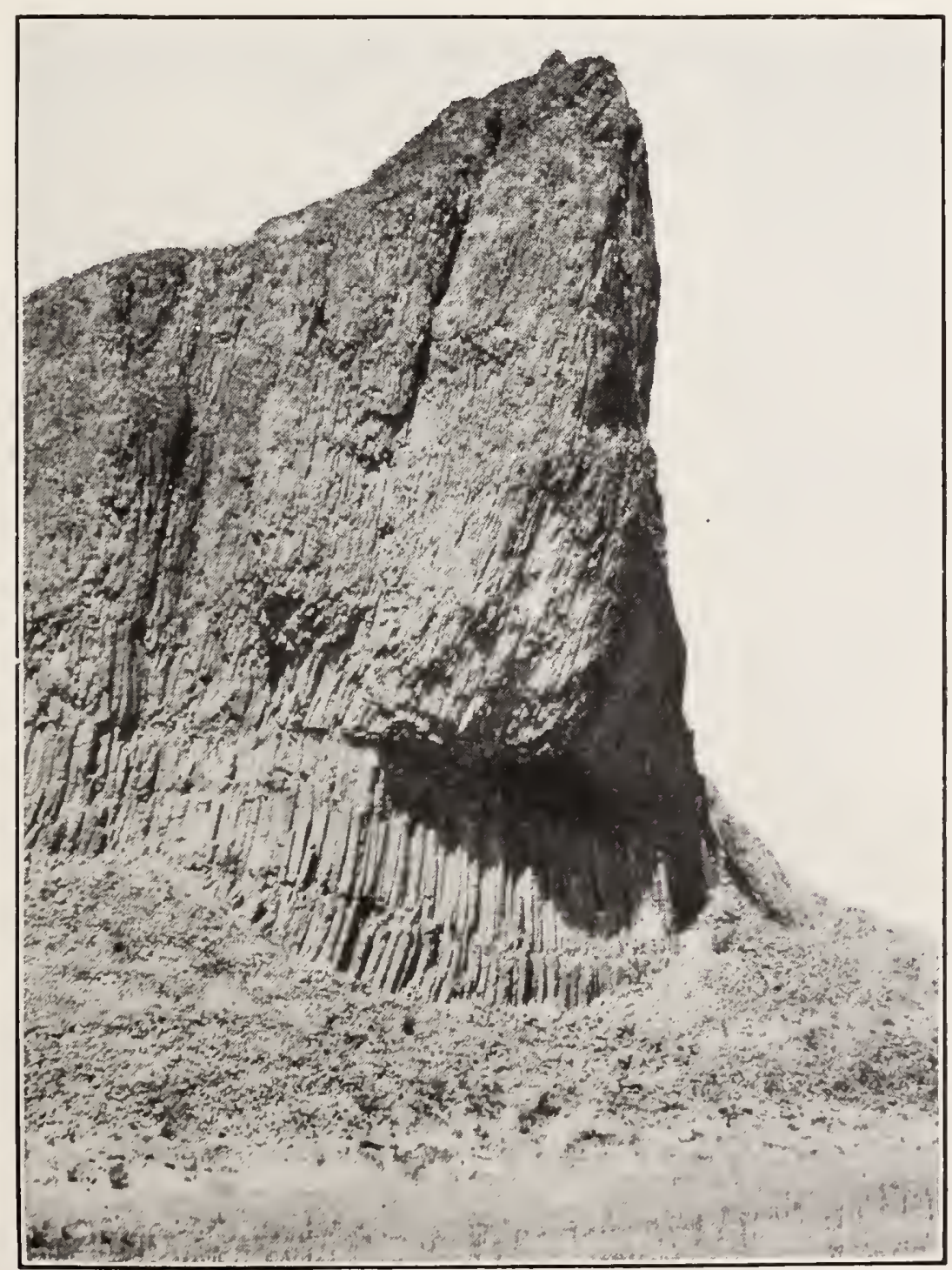

B. COLUMNAR LAVA AT CACTUS SIDING, 5 Miles SOUTH OF CONNELL, WASH.

On cooling the lava has formed columns or prisms which in places are remarkably regular. The columns stand at right angies to the cooling surface of the flow. 


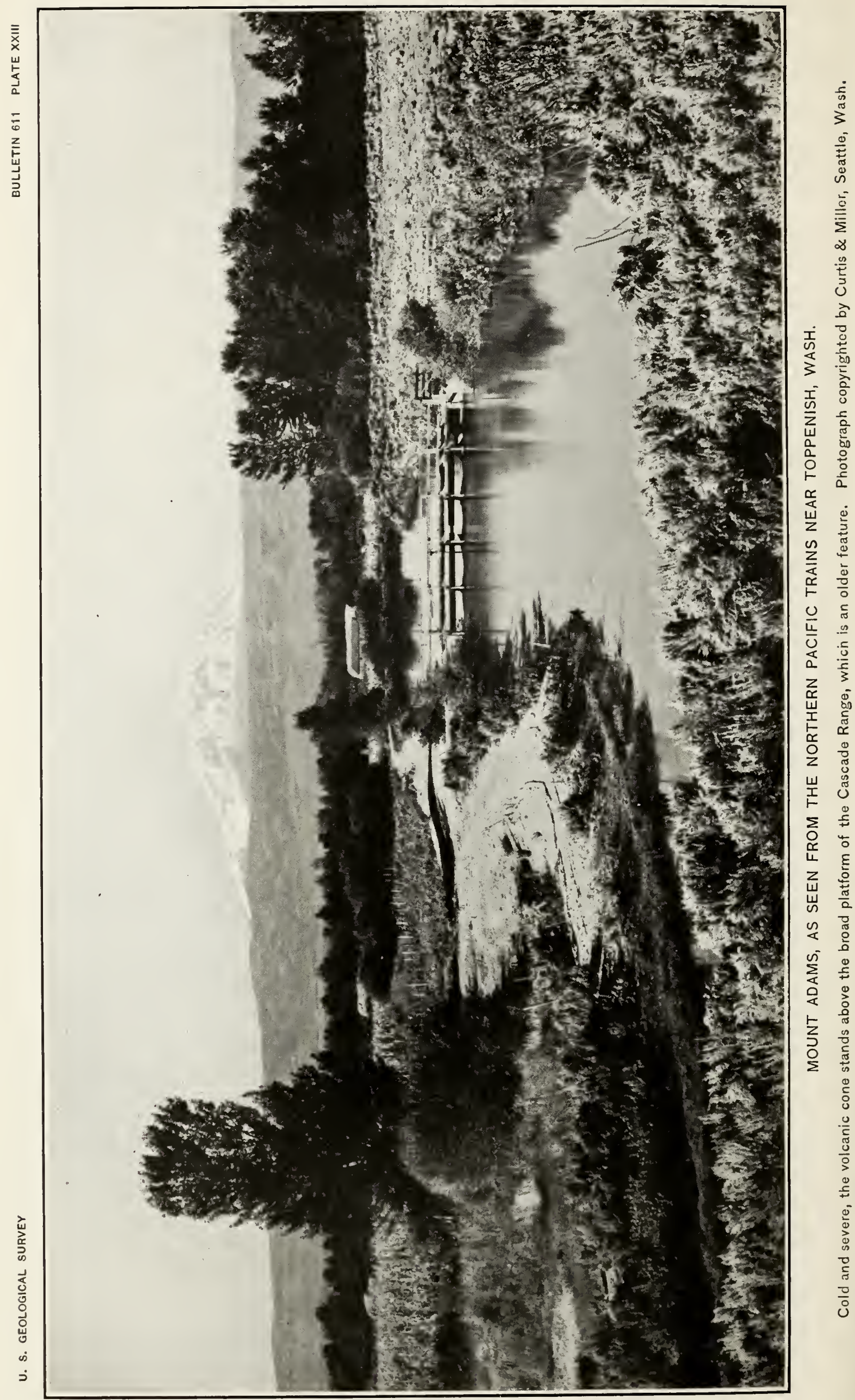


on the right (west). This cliff is about 150 feet high and in the lower part shows beautiful columnar structure (see Pl.

Mesa.

Elevation 687 feet. Population 366.* St. Paul 1,625 miles. XXII, $B$ ), but the columns are small, and they may not be visible from the train. 'The rugged walls continue as far as Mesa, but beyond that station the valley opens and the walls are lower and have lost much of their rugged character.

poured forth. The eruptions were accompanied by explosions, which produced large quantities of tuff, volcanic ash, and pumice. While the volcanic eruptions were in progress, the rocks of the Cascade region were folded and crushed and somewhat uplifted, and the streams, made more powerful by the increase in grade due to the uplift, carried vast quantities of the andesitic material eastward to the lake basin previously described. In this body of fresh water the waste material was deposited as mud, sand, or gravel, together with some sheets of basaltic lava that apparently marked the last expiring gasp of the giant forces which had previously poured forth such irresistible floods of this material. In the Yakima Valley the beds thus laid down have been named the Ellensburg formation. Here the sediments are coarse, indicating nearness to the margin of the lake and to the source of supply, but farther out in the basin, according to I. C. Russell, the material deposited in this lake is largely white silt, composed chiefly of volcanic dust and ash that were blown out of the new set of volcanoes which then were active to the west. This material is exceedingly fine and forms the White Bluff on Columbia River some distance above Pasco (Pl. XXII, A) and the isolated hills at Fishtrap.

Up to the close of the lake period of central Washington the Cascade Range, as it is known to-day, did not exist. During the deposition of the Ellensburg formation the area now occupied by the range was being worn down by streams, and finally it reached that state of low relief that is called a peneplain. Its surface was then not very far above sea level and it bore little resemblance to the region as it is known at the present time.

The great uplift of the Cascade Range came as the closing event in the Tertiary history or the opening chapter in the Quaternary. These mountains were not formed by a volcanic outburst, although such events were of common occurrence in this country, but they are the result of a gradual uplift of this part of the earth's crust, which produced a great arched plateau about 5,000 feet above sea level.

Volcanic activity was not entirely suspended in this region, and here and there vents were formed from which poured forth lava and volcanic ash, and large cones were built upon the surface of the deeply eroded plateau. These are the great conical peaks which are such majestic features of the Cascade Range.

The next great epoch in the geologic history of this region was that of glaciation, when great ice sheets came down from the north and also from the local mountains. The plain of the Columbia was invaded by two ice masses-one from the northeast by way of Spokane, and the other coming down the valley of Okanogan (o-kan-og'an) River and then across the immediate canyon of the Columbia That great river in this time of flood was temporarily diverted to a course near Coulee City, but on the retreat of the ice it resumed its original channel. The great cold of the glacial epoch left large parts of this region without a cover of vegetation, and much of the soft material laid down in the lake previously described was picked up by the winds and whirled away to the east, where it finally settled as a mantle over the entire region. As the winds which transported the dust were not markedly periodic and as the fine material settled particle by particle like snow, the deposits are homogeneous and not marked by lines of stratification.

Such, therefore, seems to have been the mode of origin and the manner of distribution of the white earth, generally called by geologists loess. 
If it is a hot day in midsummer when the traveler passes down the coulee, he may wonder whether the great flows of basalt are not still heating the surface. The plain of the Columbia, Eltopia.

Elevation 598 feet. Population 252.* St. Paul 1,634 miles.

which he is rapidly approaching, has a reputation for great heat in the summer, but as it does not show a corresponding high temperature in the other parts of the year it seems obvious that the great heat is caused by the configuration of the mountains and their effect on the movement of the atmospheric currents.

South of Eltopia (see sheet 24, p. 172) the canyon followed by the railway becomes shallower and finally merges with the broad plain of Columbia River. The lava underlies the plain but dips more rapidly toward the south than the slope of the surface, and at Pasco, as shown by drill records, it lies more than 200 feet below river level. This plain is composed of soft clay and sand (Ellensburg formation) and back from the river, where irrigation is impossible, it is nothing but a sagebrush desert. In places the regular surface of the plain is interrupted by low dunes of sand which have drifted up the slope from the channel of the Columbia. The traveler may wonder what can subsist in so desolate a land if he has not yet learned that in many places water can be procured by digging and that the soil stores up enough moisture to raise fair crops when properly cultivated. The climate of the region is semiarid, the precipitation being from 6 to 12 inches a year. The temperature ranges from a minimum of $10^{\circ}$ below zero in winter to $110^{\circ}$ above zero in summer.

Pasco is a division terminal of the railway and the center of a large irrigated district lying above the town and on the east side of the river. The shade trees and green lawns of the town are in

Pasco.

Elevation 389 feet. Population 2,083. St. Paul 1,651 miles. striking contrast to the brown sagebrush of the surrounding country.

Immediately after leaving the station at Pasco the train is upon the great bridge that spans the swirling waters of the Columbia, ${ }^{1}$ one of the great rivers of the continent-a

${ }^{1}$ One of the most interesting parts of the history of the exploration of the northwestern part of the United States is the story of the discovery of the mouth of the Columbia, or rather of the failure to find it by the many navigators who sailed up the western shore for the very purpose of discovery.

In 1788 an English captain discovered and named Cape Disappointment, just to the north of the river's mouth, without recognizing in the inlet to the south the mouth of the greatest river on the coast. In 1789 two Boston trading ships, the
Washington and the Columbia, under the command of Capt. Robert Gray, visited the coast for a cargo of furs. Gray thought he saw indications of the mouth of a large river in latitude $46^{\circ} 10^{\prime}$ but did not stop to investigate, and after completing a voyage around the world his vessel, the Columbia, was again dispatched to the Pacific coast in 1791. He spent the winter at Nootka Sound, on Vancouver Island, and in the spring cruised south from the Strait of Fuca in search of the river which he thought he saw three years before. On his way he met the English 


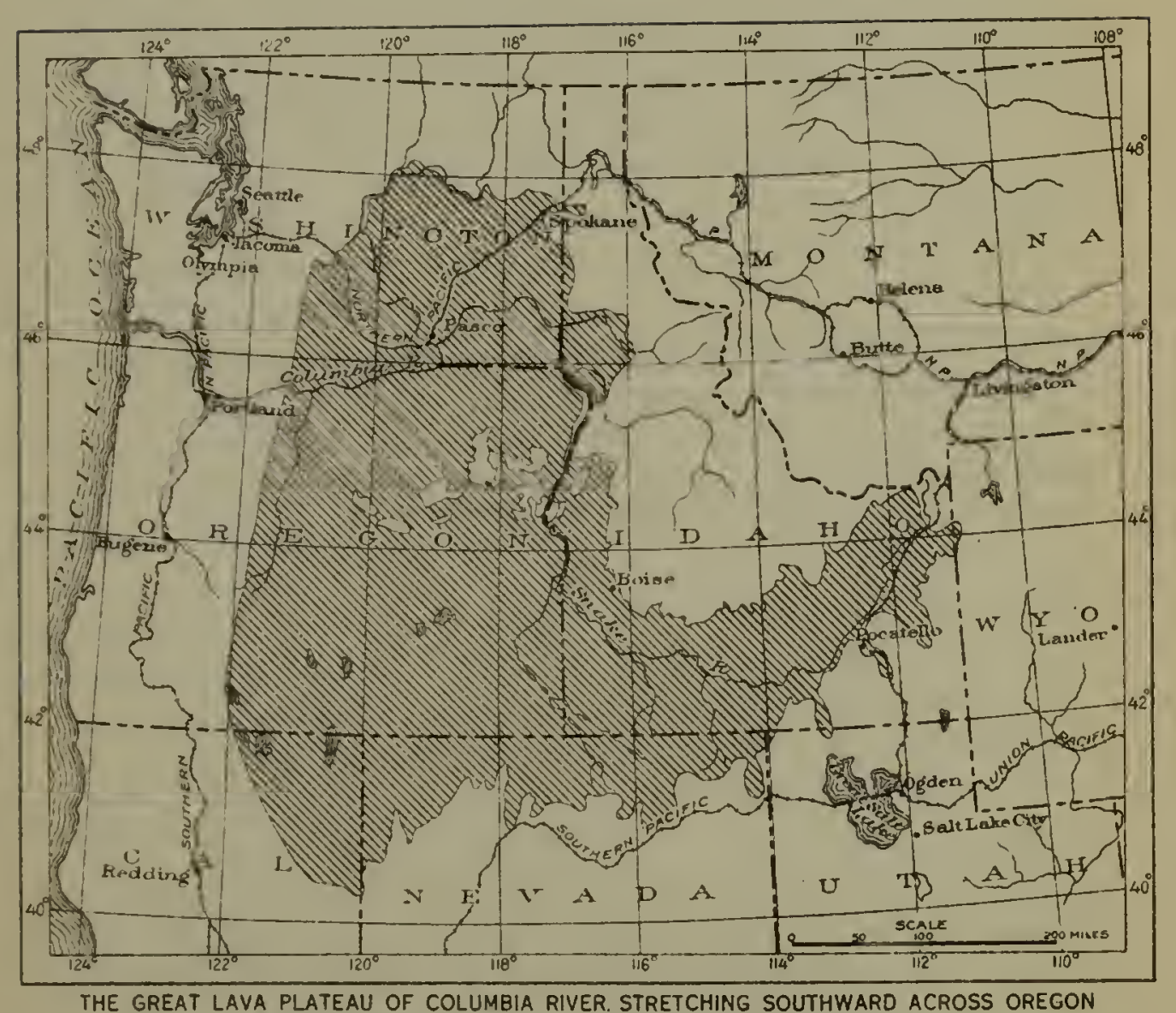

NVA PLATEAU OF COLUMBIA RIVER STRECCHNG SOUTHWARD
AND EASTWARD NEARLY TO YELOWSTONE NATIONAL PARK
BULLETIN 611

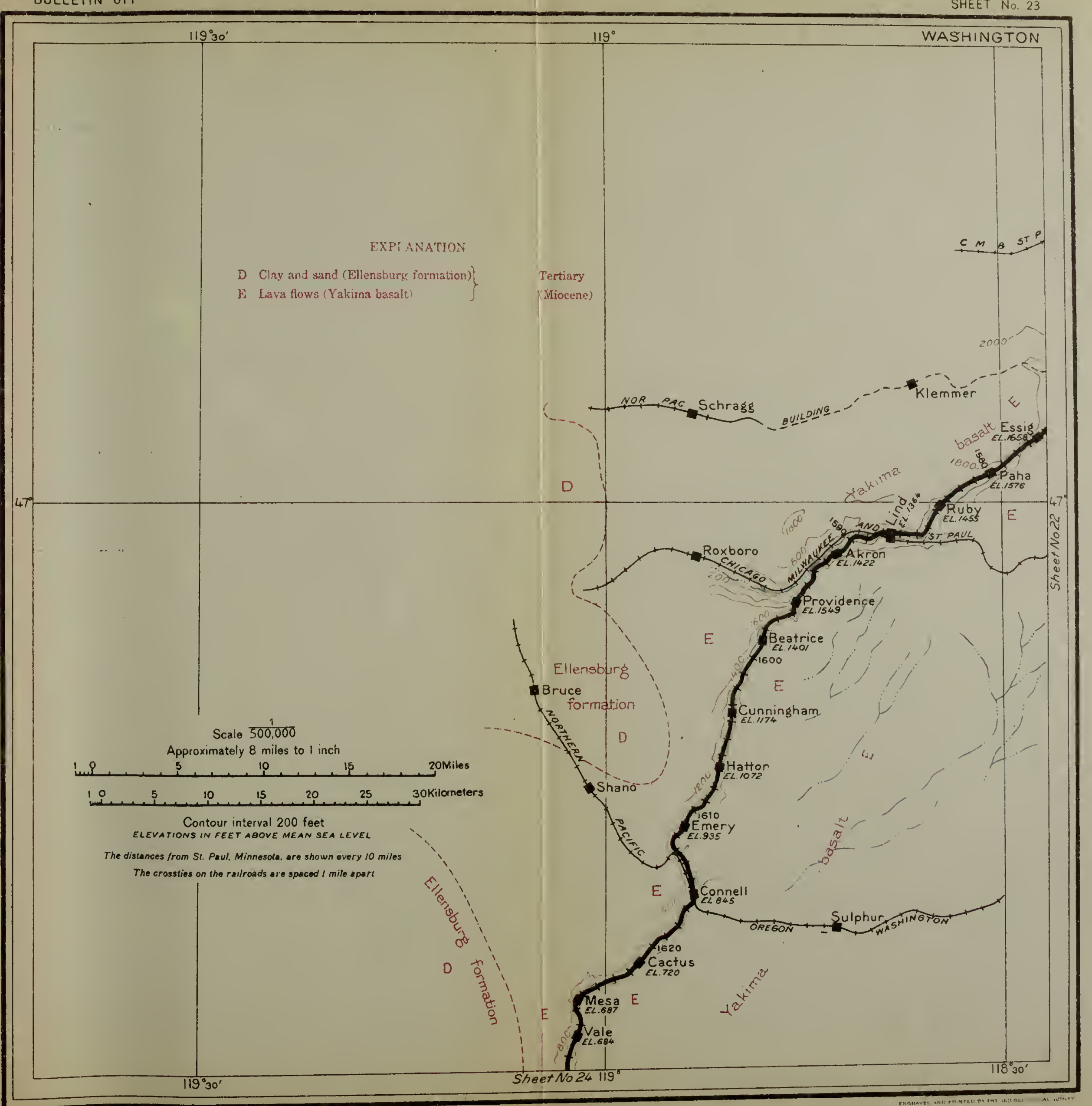



river that is fed from the melting snows on the mountains of most of the northwestern part of this country and a large part of the mountain region of Canada.

Although the Northern Pacific crosses Columbia River only a few miles above the mouth of Snake River, the junction of these two streams can not be readily seen from the train, but the OregonWashington Railroad \& Navigation Co.'s bridge which crosses just below the Snake is clearly visible. When the traveler reaches this point in his westward journey he has been out of St. Paul only 48 or 50 hours, but when Lewis and Clark camped at the mouth of the Snake in October, 1805, they had been gone from St. Louis 18 months. At that time the ownership of Oregon Territory was uncertain and most of the men, if not the leaders themselves, believed that they were on foreign soil, as many entries in their journals refer to what they expected to do when they returned to the United States.

The first white man to explore the Columbia above the mouth of the Yakima (yak'i-ma), which enters a few miles west of Kennewick, was David Thompson, who made a trip down the river from Spokane in the year 1811.

Soon after passing Kennewick, a thriving town grown up in the center of a rich irrigated district on the south side of

\section{Kennewick.}

Elevation 372 feet. Population 1,219 . St. Paul 1,654 miles. the river, the train crosses a branch line of the Oregon-Washington Railroad \& Navigation Co. that runs up the valley of Yakima River as far as North Yakima.

After the dull, monotonous sagebrush plain above Pasco, the orchards and fields of green alfalfa are a pleasing sight. The fields first seen are those on the lowest bottom of the river, Vista. but as the railway reaches Vista it is running on a Elevation 576 feet. second terrace which is also irrigated and under a


g 2

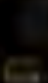

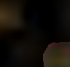
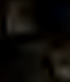

$=$
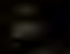

E

e

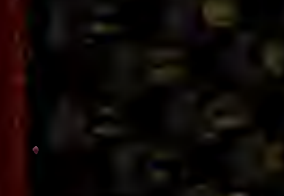

is

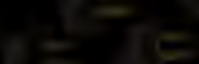

e- $=$
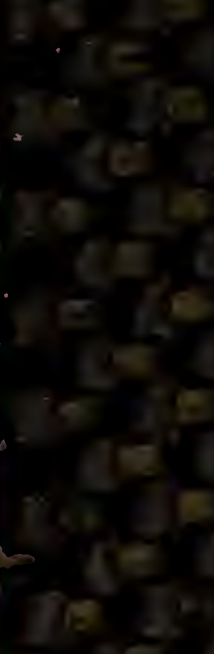
a. 4

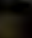
8 $-18$ 
Although the Northern Pacific Railway in a general way follows the valley of Yakima River, it does not adhere closely to that stream, but cuts across country, thereby avoiding a big bend. Along this cut-off there is no irrigation and the country is desolate in the extreme. Before water was put upon the Yakima Valley it was a sagebrush plain just as extensive and just as desolate as the one here traversed. Water is the wizard that has transformed this desert into a land of blossoms, and as time goes on more and more of the waste places of the earth will be redeemed in this manner.

Not only is the surface of the country from Vista to Kiona monotonous, but the rocks, while interesting in so far as they record the past history of the region, are monotonous and poorly exposed. As explained on page 165, the rocks in this part of the valley consist of sandstone and shale formed from sediment laid down in lakes or on the surface of the land, interspersed with great sheets of lava (basalt) that covered most of the country. The lava was not poured out in a single flow, but the entire region is underlain by a succession of lava sheets. The shale and sandstone are soft and in only a few places show at the surface, but the outcrops of the sheets of basalt are marked by dark ledges along the hill slopes and the streams of rock fragments that descend from them.

At Kiona the railway approaches Yakima River,

\section{Kiona.}

Elevation 525 feet. Population 291.*

St. Paul 1,675 miles. and just after passing the station the traveler can obtain a good view down the valley, which includes well-cultivated farms and the bridge of the OregonWashington Railroad.

A short distance west of Kiona the valley is much restricted and all irrigation ceases. The river is bordered by rugged walls of basalt,

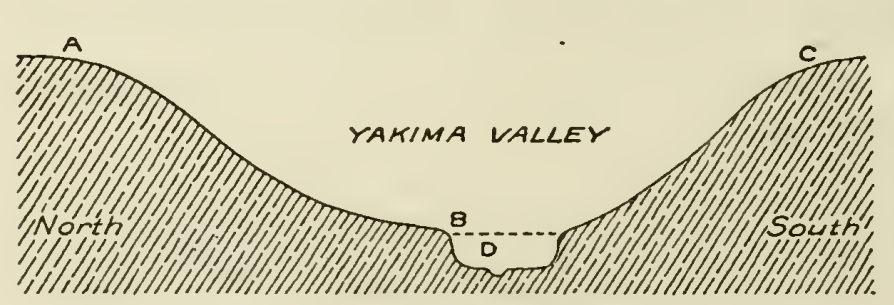

Figure 35.-Section of Yakima Valley east of Prosser, Wash., a valley within a valley. a good view of which can be obtained from milepost 31 by looking back from the rear of the train. From this point of vantage it will be seen that the valley is not smooth and regular, sloping gently from the tops of the ridges to the river bank, but that it is compound, consisting of a rather broad outer or upper valley and an inner rocky gorge cut in the floor of the large valley. The shape of the valley is represented by the accompanying diagram (fig. 35), in which the outer broad valley is represented by the section $\mathrm{ABC}$ and the inner valley by the sharp cut at $\mathrm{D}$. Usually such an arrangement is considered as indicative of two periods of valley cutting under somewhat different conditions, but 
here the forms have not been studied with sufficient care to make a determination possible. There is so great a difference in the hardness of the basalt and the soft sandstone associated with it that the inner valley may be due to a harder and much more massive bed of basalt near the bottom and not to different conditions of erosion.

About Prosser there is a large area of land under irrigation and in a high state of cultivation. It is a pleasing change from the dark or dull-gray color of the barren areas to the brilliant green of the fields of alfalfa, grass, or oats; from the stunted vegetation of the sagebrush plains to the thriving orchards which stretch away in the distance almost as far as the eye can see. It is no less pleasing
to pass from the dry plains of the sun-scorched desert, where clouds

\section{Prosser.}

Elevation 671 feet. Population 1,298 . St. Paul 1,691 miles. of dust fill the air, to a land where running water is seen in every irrigation ditch and the land is so covered with rich vegetation that there seems no chance for it to become dry and parched. ${ }^{1}$

The railway runs some distance back from the river through irrigated fields, but gradually climbs to a terrace which shows on the Byron.

Elevation 702 feet. St. Paul 1,696 miles. left about a mile beyond Byron. This terrace is doubtless built of the soft material washed into the valley by the streams, but the amount of such material is variable, as the basalt appears at railway level in a number of places. On a clear day the high peaks of the Cascade Mabton.

Elevation 725 feet. Population 666 . t. Paul 1,703 miles. Range, 100 miles away, can be seen from the vicinity of Pasco, but the distance is so great that at first sight the traveler may be disappointed in them. A better view can be obtained near milepost 58, 6 miles beyond Mabton, but even from this place the peaks are not as striking objects as they are from the region about Top-
oenish, farther northwest. 
After passing Empire (see sheet 25, p. 176), Satus, Toppenish Ridge, and Alfalfa the traveler can get a full view of Mount Adams, far to the west. Although it is here more than 50 miles Alfalfa. distant, its great height (12,307 feet above sea level) Elevation 723 feet. Population 81.* St. Paul 1,717 miles. makes it conspicuous. (See Pl. XXIII, p. 167.) To one unaccustomed to judging of the magnitude of distant mountains, the first view of Mount Adams may be disappointing, but after watching it for some time and comparing it with objects near by the observer will find that its enormous bulk becomes more apparent. How cold it seems in its eternal pall of white! The mountain looks like some patrician of old, holding himself erect and aloof from all surroundings! Long ago it was an active volcano emitting molten lava, but its activity ceased, and for unknown ages the mountain has stood the cold, calm, rugged peak it is to-day. Just beyond Mount Adams and from many points of view hidden by it is Mount St. Helens, which within the memory of the white man has showed signs of volcanic activity. It is apparent that the volcanoes of the Cascade Range, while possibly extinct, have not been so for a great length of time. That they may be only smoldering is indicated by the recent outburst of Lassen Peak, in California, which stands along the same line of volcanic disturbance. ${ }^{1}$ Mount Adams remains a magnificent spectacle, until the view of it is shut off by the Atanum Ridge, north of Parker. Although

Toppenish.

Elevation 765 feet. Population 1,598. St. Paul 1,721 miles. the country about Toppenish lies within the Yakima Indian Reservation, it is well watered by ditches that receive their supply from the river in the vicinity of the next ridge, which can be seen in the distance. The land is well cultivated, though not so intensively as that covered by the Sunnyside reclamation project across the river.

While enjoying the beautiful spectacle of Mount Adams, the traveler should look a little farther to the north where, if the atmosphere is clear and no cloud banners intervene, he may be fortunate enough to catch a view of the summit of Mount Rainier (Tacoma),

${ }^{1}$ The view from Alfalfa or Toppenish gives to the traveler an excellent idea of the height and character of the Cascade Range and of the volcanic cones which project above its apparently even crest line. In order, however, to understand fully the relations of these cones and the character of topography of the platform upon which they are built, it is necessary to know something of the geologic history of the range and of the conditions which have tended to produce its present form.

After the great lava sheets were spread out and somewhat deformed by folling, the region was subject to the action of the elements, and the rain and streams reduced the surface to a nearly uniform plain only a slight distance above sea level. From this plain the present Cascade Range was formed by a gradual uplift of the surface along the axis of the mountains. This upward movement continued until the surface was raised to a height of 4,000 feet above sea level in the south and about 8,000 feet in the north, In this uplifted mass the streams carved deep channels or canyons, almost destroying the plateau and leaving only the 


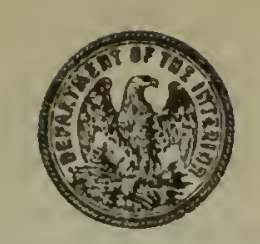

GEOLOGIC AND TOPOGRAPHIC MAP

NORTHERN PACIFIC ROUTE

From St. Paul, Minnesota, to Seattle, Washington

Base compiled from United States Geological Survey Atlas

Sheets. from railroad alignments and profiles supplied by

the Northern Pacific Railway Company and from additional

UNITED STATES GEOLOGICAL SURVEY

GEORGE OTIS SMITH. DIRECTOR

David White. Chief Geologist

R. B. Marshall. Chief Geographer

1915

Each quadrangle shown on the map with a name in parenthesis in the

lower left corner is
Sheet of that name.

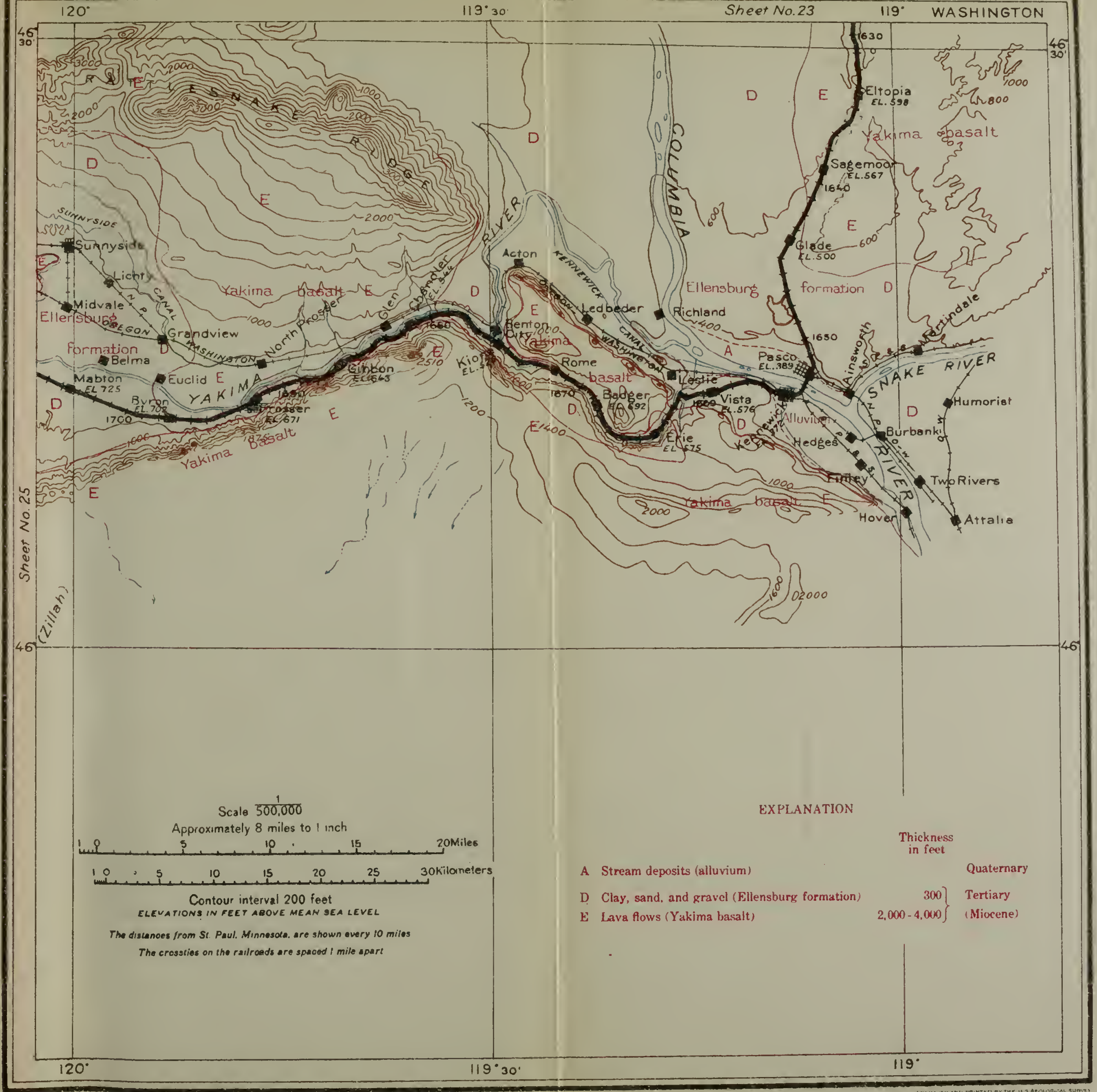



14,408 feet in altitude, the highest peak of the Cascade Range, but this view gives him little idea of the magnitude and grandeur of the mountain.

The great sheets of basalt that underlie the Yakima Valley are in places thrown into low folds by pressure in the crust of the earth exerted in a north-south direction, and consequently the folds trend at right angles to that direction, or nearly east and west. As these folds bring up the hard basalt, they make ridges or mountains across the country, the length of the ridge depending on the

Wapato.

Elevation 865 feet Population 400 . St. Paul 1,729 miles. the extent of the fold. The big ridge lying to the south of the railway from Kennewick to Mabton is supposed to be of this character, although its structure has not been accurately determined. This broad upland, from is original cover of abundant and nutritious bunch grass, is known as Horse Heaven. The next ridges to the north are Toppenish Ridge west of the river and Snipes Mountain on the east. These appear to be parts of one general line of disturbance but are separate folds. In Snipes Mountain the arch is so low that the basalt is scarcely visible under the cover of the Ellensburg formation.

The next anticline to the north, which lies north of Toppenish, is known west of the river as $\Lambda$ tanum Ridge and east of the river as Rattlesnake Ridge. The Yakima has made a deep,

Parker.

Elevation 930 feet. Population 823.* St. Paul 1,733 miles. narrow cut, called Union Gap, through this ridge north of Parker. At the south entrance to the gap the Northern Pacific crosses the North Yakima branch of the Oregon-Washington Railroad. The gap is about a mile in length, and the sheets of lava at the south entrance dip toward the south at an angle of about $20^{\circ}$. The oppo- 
In a region in which the annual precipitation is so small (8.9 inches) as it is in the Yakima Valley the quantity of water flowing in the streams and available for irrigation is of the utmost importance. In order to determine the volume of water in Yakima River the United States Geological Survey maintained for a number of years a gaging station in Union Gap, but for the last six years the station has been near Wapato, a few miles below the gap. By means of a small car swinging from a steel cable the engineer is able to measure the velocity of the current at a number of points across the stream, and from these measurements, together with other measurements of the cross section of the river, compute the volume of water available for irrigation and the development of power. ${ }^{1}$

North of Union Gap the valley broadens into a parklike country, all of which is under irrigation and highly cultivated, except near the river, where the land is excessively wet. The original Yakima City was situated just above Union Gap, and the station, the only remaining structure on the site, can be seen near milepost 86 . Trouble arose between the railway and the town promoters and the station was abandoned, and a new station, called North Yakima, established about 4 miles north of the old one. With the growth of the new town of North Yakima the older settlement soon died out.

North Yakima is the largest town in central Washington and is the commercial and social center of the Yakima Valley, one of the largest areas of irrigated land in the West and one

\section{North Yakima.}

Elevation 1,076 feet. Population 14,082.

St. Paul 1,741 miles. Range, where the snowfall is abundant. Fruit raising is the principal occupation, but there are also broad fields of grain, alfalfa, and hops, indicating that the farmers feel the necessity of a diversity of crops,

${ }^{1}$ A gaging station has been maintained in this vicinity since November, 1896. It shows a mean annual flow of 4,640 second-feet (a second-foot means 1 cubic foot per second), which equals $3,360,000$ acre-feet (an acre-foot is 43,560 cubic feet, or the quantity required to cover 1 acre to the depth of 1 foot).

About 1,500 river-measuring stations similar to the one at Union Gap are now maintained by the United States Geological Survey on the more important streams in the United States and in the Hawaiian Islands. The data collected at these gaging stations are of prime im- portance in developing the water resources of the country and are used in designing and operating power and irrigation plants, city waterworks, and other works whose establishment and successful operation depend on a knowledge of the quantity of water flowing in surface streams.

${ }^{2}$ According to the United States Weather Bureau, the mean annual precipitation in the Yakima Valley from 1893 to 1903 was 8.9 inches, divided as follows: Winter, 4 inches; spring, 2 inches; summer, 0.7 inch; autumn, 2.2 inches. 


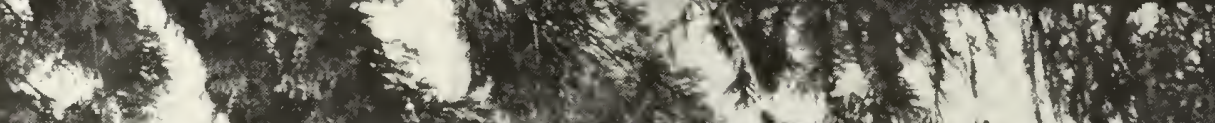



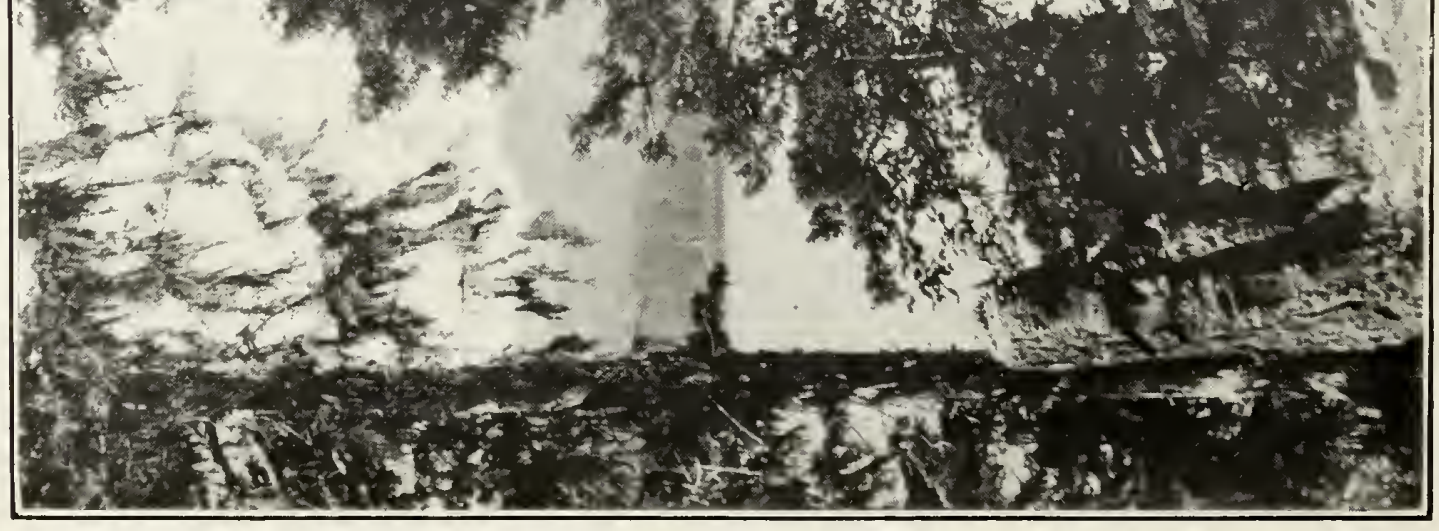


so that in case of an oversupply of one they will have another to fall back upon.

The volcanic rocks that border the Naches Valley and extend within a few miles of North Yakima furnish an interesting example of a recent lava flow. The hummocky surface of this plateau between Naches River and Cowiche Creek, although in places covered by sagebrush and bunch grass, exhibits the essential features of a cooling lava flow, and at many points on its borders the characteristic jointing due to contraction on cooling is shown in rare perfection. (See Pl. XXIV, B.)

North of North Yakima the railway crosses Naches River and then passes through Yakima Ridge in a short canyon cut in the thick layers of basalt, which have here, as in the other ridges to the south, been folded into a low anticline. ${ }^{1}$

\footnotetext{
${ }^{1}$ After having traveled up Yakima River for nearly 100 miles and passed through a number of basalt ridges, the traveler may be surprised at the apparent disregard of the stream for the ridges and valleys. As stated previously, the principal arches and troughs into which the rocks have been bent trend in a nearly east-west direction, and if the streams followed similar courses they would encounter little difficulty in reaching their destinations. But instead of following the synclinal valleys Yakima River flows almost due south and crosses in this part of its course no less than seven ridges of arched or upturned basalt. What made the stream select its present course, and why did it persist in this course across the

duced. After the streams were well established, in about the same courses that they follow to-day, a great north-south pressure wrinkled the rocks into a series of broad, shallow troughs and rather short arches. Many persons think of such a movement as having occurred suddenly and as having crumpled the rocky layers as leaves of paper may be crumpled in the hand. If the movement had been sudden, then the southward-flowing stream would have been dammed wherever one of the arches crossed its pathway, and Yakima River, instead of flowing as it does to-day, would have been broken into a number of separate streams, each of which would probably have found an outlet to the east into Columbia River. As
} 
The canyon is short and north of the ridge lies Selah Valley, one of the prettiest valleys in this part of the country. 'The land is rolling

\section{Selah.}

Elevation 1,108 feet. Population 1,524.* St. Paul 1,744 milos. or even hilly along the sides of the valley, but water is carried in a high-line canal, so that all the hills and slopes below it are highly cultivated, and orchards extend as far as the eye can see. The basalt dips under the valley, but a little farther north it rises above water level, and the river has cut a sharp canyon with vertical walls from 50 to 70 feet high. The main canyon, which begins near milepost 99 (see Pl. XXIV, $A$ ) is cut through three separate but parallel ridges of basalt, each of which was produced by a low uparching of the lava, as shown in figure 36. At the entrance to the deeper part of the canyon the great sheets of lava, each representing an individual flow, rise more steeply toward the north, their dip $\left(20^{\circ}\right.$ or $\left.25^{\circ}\right)$ corresponding in a general way with the south slope of the ridge. The walls of the canyon increase in height until at milepost 103, where the railway crosses the river, they are nearly 2,000 feet high. Here the rocks are about horizontal, indicating that this



FIGURE 36.-Fold in basalt north of Roza, Wash., as seen from a point near W ymer, looking southeast.

is the middle (axis) of the fold, from which the beds dip in opposite directions. North of the axis the layers of basalt dip $30^{\circ}$ or $35^{\circ}$ to the north.

The northward dip continues to Roza, near milepost 106, where two lateral valleys entering on opposite sides of the river mark the depression or trough between the ridges. Toward the east the ridge south of Roza extends for a long distance, but in the other direction it dies down rapidly, and in a distance of 5 or 6 miles has disappeared.

Beyond Roza the beds of lava rise northward about $30^{\circ}$ up the slope of Umptanum Ridge, which is a few hundred feet higher than the one south of Roza. The axis of the fold is reached about

\section{Roza.}

Elevation 1,258 foet. St. Paul 1,756 miles. milepost 109, and beyond this point the beds can be seen to bend over in a great arch; but the traveler is so close to the rocky wall that it is impossible for him to obtain a satisfactory idea of the size or shape of the fold until he has gone some distance past it. At Wymer siding, between mileposts 110 and 111, a good view of the fold on the east side of the river can be obtained by looking directly back from the rear of the train. (See fig. 36.) From this point the fold is seen to be unsymmetrical, with the steepest dips on the north side. 

All the lava folds crossed so far in the Yakima Valley are either steepest on the north side or overturned, like that of Atanum Ridge at Union Gap. This overturning toward the north indicates that when the folds were produced the thrust came from the south, and it continued not only until the beds were arched but until the arch was pushed over, so that the beds on the north side stand nearly vertical or dip steeply toward the south. The northern limit of this fold is marked by the valley of Umptanum Creek (see sheet 26, p, 186), which enters the river near milepost 114.

North of Umptanum Creek lies Manastash Ridge, which, like the others already crossed, is an arch in structure; but the fold is much flatter than those down the river, and its shape is not apparent from the train. The layers of basalt rise gradually northward from the mouth of Umptanum Creek, and they appear to be nearly horizontal in the great Beavertail Bend between mileposts 115 and 118. The axis of the fold is more than a mile north of this bend and not far from milepost 120; where the railway again crosses to the easi side of Yakima River. From this crossing the layers of rock descend rapidly northward, and the great sheets of basalt that form the walls of the canyon for more than 20 miles dip below water level and the train emerges upon another broad flat that seems to be even more extensive than the one at North Yakima. This also is mostly under cultivation, and the view on the right as the train leaves the canyon is particularly charming, as one looks off to the distant mountains across a wide stretch of fertile fields and orchards, crossed here and there by lines of tall trees planted as windbreaks.

Although much hard rock is exposed in the Yakima Valley stone suitable for building material is very scarce. The basalt is a lasting Thrall. material, but its dark color renders it unsuitable for 
suited to the raising of hay and to dairying than that of the lower valley.

A little north of Ellensburg Mount Stuart, far to the north, stands up as a narrow, jagged crest carrying much snow. This view is not so imposing as that of Mount Adams seen from a point farther down the valley, but the summits here are much narrower than that of Mount Adams and the mountain has a more rugged outline. The railway is bordered by broad meadows of timothy or clover and by fields of oats or wheat that roll in great billows under the strong wind that at times sweeps down the valley from the mountains. About a mile from the station the St. Paul Railway is visible on the right, having crossed Columbia River by a route leading directly west from Connell.

The bluff on the right near milepost 4 is composed of the Ellensburg formation, which overlies the great flows of basalt and is composed of white clay (in most places volcanic ash), sand, and gravel. This material is only partly consolidated, but it stands in steep bluffs, as can be seen on the right. The material is so soft and the slope so steep that in carrying water along the bluff to irrigate lands lower down the valley a timber flume had to be built along the entire face of the bluff a distance of more than 2 miles. This gives an idea of the elaborate and expensive work that must be done in many localities in order to obtain the necessary water for irrigation. Not only is the first cost of such a flume great, but the maintenance is a considerable item of expense which must be met every year.

Just after passing milepost 7 the train crosses Yakima River, here a small stream but beautifully clear and pure, and then it Thorp.

Elevation 1,647 feet. St. Paul 1,785 miles. follows the river bottom, in some places on the bank of the stream and in others back at the foot of the bluff as the river swings from side to side of its flood plain. Near milepost 10 the railway again crosses the river, and the St. Paul road is on the other side under a high bluff, in which is exposed a prominent band of white volcanic ash. At the first sharp curve north of the river crossing the basalt is at track level, but it rises up the stream with the soft, stratified beds of the Ellensburg formation which rest upon it and which rise in the same direction and at the same rate.

The canyons south of this place have been cut by Yakima River through low rolls or folds in the basalt, but none of these folds have been of sufficient magnitude for the river to reach the base of the lava sheets; but north of Ellensburg the whole series of rock formations has been turned up like the rim of a basin, and the canyon which begins at Dudley, 10 miles above Ellensburg, is the cut made 
by Yakima River through the basalt of this rim. Figure 37 shows the gradual rise of the basalt northward and its final disappearance in the hilitops far above river level.

In some parts the canyon is bounded by rugged walls of basalt which makes it somewhat picturesque, but in general there is little

\section{Bristol.}

Elevation 1,803 feet. St. Paul 1,794 miles.

pine trees that are but the fringe of the great mantle of forest that covers all of the Cascade Range except the highest

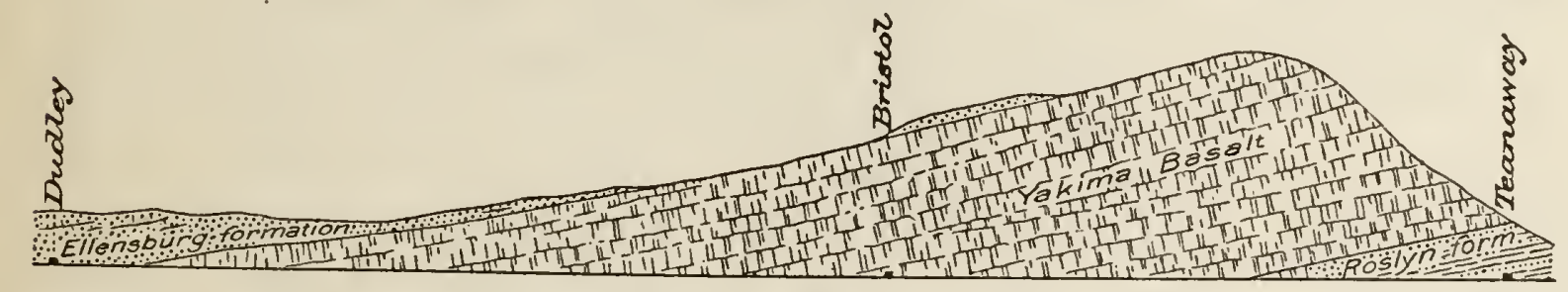

FIGURE 37.-Section showing structure of Yakima basalt north of Ellensburg, Wash. The basalt rises from a level below Yakima River near Dudley and is far above track level at Teanaway.

summits and that once extended unbroken to the shores of the Pacific Ocean. The basalt rises steadily and near milepost 18 the whitish sandstone and clay of the underlying older formation makes its appearance in cuts along the St. Paul road, on the opposite shore of the stream.

The traveler should be prepared to see Mount Stuart on the right (north) as the train emerges from the canyon, for the view, if the weather is clear, is superb and lasts for only a few minutes. ${ }^{1}$

The white sandstone of the Roslyn formation is visible in a low bank on the right near the old station of Teanaway. It rises toward

${ }^{1}$ Mount Stuart is the culminating peak | space is taken by the United States Geo-

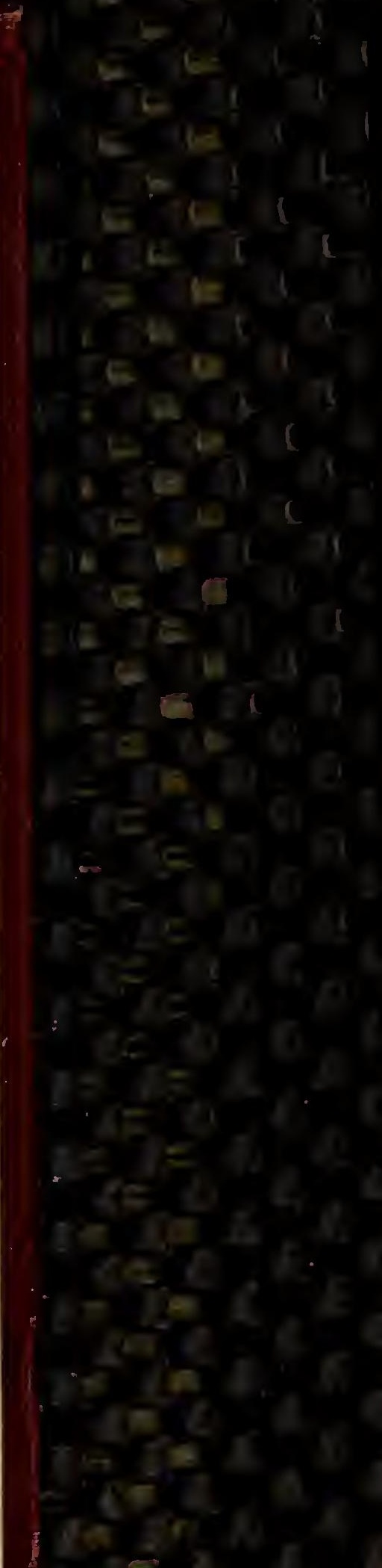


the north, like the formations observed in the canyon, and it forms the southward-facing slope of the great ridge on the right. The red rocks on the mountain side on the left are the Teanaway basalt, which underlies the Roslyn formation and is of Eocene age. The layers of basalt in this mountain are not horizontal but are turned up on edge, so that the relation of the Teanaway to the Roslyn is not apparent.

The valley here was formerly covered with dense forest, in striking contrast to the valley lower down, where there were few trees of any kind until the country was settled.

Near Clealum a heavy-bedded white sandstone, underlying some coal beds, dips to the south with the same slope as the side of the valley, and consequently it covers the entire hillside.

\section{Clealum.}

Elevation 1,920 feet. Population 2,749.

St. Paul 1,802 miles. Three coal tipples are in sight from the train. Some coal is produced here, but most of it comes from mines farther from the main line of the railway. From Clealum a branch line leads to the right to Roslyn, where are situated the mines of the Northern Pacific and also of companies that are mining coal for sale. The Roslyn coal field is one of the most valuable in the State. It has made its reputation largely because of the cleanness of the coal and its good quality for steam raising and for domestic use. The Northern Pacific Co. uses the coal mined here for all its locomotives and stationary engines between the Stampede tunnel on the west and Butte and Helena on the east. Clealum has also been the supply point for the three principal gold-mining districts in central Washington. ${ }^{1}$

high point. The difference in the form of the two peaks is due to differences in materials and in mode of formation.

Mount Stuart consists of a great mass of granite which long ago was forced up through the rocks from below but probably never reached the surface. Before Tertiary time this great mass, together with the surrounding sedimentary and igneous rocks, was deformed by earth movements and possibly was uncovered and carved into mountains, though the record is not complete enough to determine that with certainty. The surface of the country was finally reduced to a lowland, except the granite mass, which owing to its hardness was left projecting about 1,000 feet above the plain. Late in Tertiary time the Cascade Range was formed by a great uplift of the rocks, and then the streams began their present work of cutting it away. Great canyons were eroded in the uplifted mass, and the pinnacles and towers of the jagged crest of Mount Stuart have been formed merely by the removal of adjacent material.

Thus while Mount Adams is a mountain of construction, Mount Stuart is a mountain of erosion. No better representatives of the types could be found than these two peaks of the Cascade Range.

1 The coal-bearing rocks of the Roslyn field lie in an open trough or syncline, the axis of which extends in a northwesterly direction parallel with the main valleys of the region. The Roslyn formation, which contains the coal beds, is about 3,000 feet thick, but the coal occurs in the upper part alone, and for this reason the coal beds are much less extensive than the formation which carries them. So far as known they are restricted to an area about 7 miles long by $3 \frac{1}{2}$ miles wide, 
West of Clealum the railway follows the north bank of the river under the cut bank of an extensive terrace of gravel, which is doubtless the outwash from the glacier that once occupied Clealum Valley. The road then bends sharply to the south around a narrow point of the terrace that has been protected from erosion by a projecting boss of the Teanaway basalt. In the early days of railroading in the Yakima Valley this was known as Deadman's Curve, from the number of fatal accidents that occurred here, but now with the use of block signals the danger has been removed.

About a mile west of this curve the railway crosses Clealum River, which drains a large valley heading far to the north and containing Clealum Lake, a body of water 4 miles long and nearly a mile wide. At the outlet of this lake the Reclamation Service has constructed a low dam to raise the level of the lake and make a storage reservoir. It is proposed to increase the height of this dam and thus impound a much larger volume of water for use in the lower valley. As the railway rounds the next point of the terrace and crosses the river a corresponding point is seen on the left, as if at one time there had been a continuous ridge across the valley at this place. This ridge has many of the characteristics of a terminal moraine, including a steep face upstream against which the ice front may have rested, a hummocky surface in that part lying to the left (south) of the track, and bowlder clay at the bottom of the cut near the railway. These features, together with the flat, smooth floor of the valley above, indicate that at a certain stage of the glaciation of this region a large body of ice came down the tributary valley now occupied by Kachess

extending from a point just a little east of Clealum northwestward nearly to Clealum Lake. Along the northeastern limb of the svncline the coal beds are well of partings of bony coal. Government analyses show that the heating value of the coal ranges from 11,950 to 12,980 British thermal units 
Lake and extended down Yakima Valley to this point. Here it rested for a while, pushing out in front the clay and rock fragments that it had ground off the rocky bed over which it had moved, and then the water flowing from the ice carried sand and gravel and spread them in a somewhat irregular sheet above the till.

Besides the moraine just described, one lies at the lower end of Kachess (ka-chess') Lake and another just below Keechelus (kee'chelus) Lake. These show that the glacier, after retreating several miles up the branching valley, came to a halt and probably readvanced a little, piling up the rocky material in each valley as a terminal moraine. Kachess Lake, the largest lake in the region, is a beautiful sheet of water nearly 6 miles long and a mile wide. A wagon road extends to the lower ond of the lake, but the upper part is still encircled by unbroken forest, which covers the inclosing mountain slopes to a height of 3,200 feet above the lake. The deep basin in which the lake lies was scoured out by the glacier that once occupied this valley. The outlet of the lake has been dammed by the Reclamation Service and the level of the water raised several feet, thereby increasing the amount of stored water available for irrigation.

The mountain side on the left (south), which can be seen to good advantage in the journey up the broad valley above the moraine, consists of schist (the Easton schist), which is the oldest geologic formation that will be seen in the Cascade Mountains. Its exact age has not been determined, but it is supposed to be Carboniferous or older. It is a part of the great foundation upon which the Tertiary sediments and lavas were laid down. The rocks on the right (north) are the Teanaway basalt, which covers large areas east of the summit of the range. Near milepost 36 the sheets of lava that make up this formation are well exposed in the high mountain summit just north of Silver Creek. The sheets of lava here dip away from the valley and they make a rugged mountain front, the steepness of which has been greatly accentuated by the scouring that the old glacier has done along the bottom of the slope.

Easton, which lies at the foot of the steep climb up to the Stampede tunnel, is mainly a place for helper engines to wait until their services

\section{Easton.}

Flevation 2,176 feet. Population 493. St. Paul 1,815 miles. are needed in pushing up the grade. The broad valley which the railway has been following for some distance continues directly ahead to Kachess Lake, but just beyond Easton the road swerves to the left and appear's to plunge directly into the hillside. From the bottom of the valley the reason for this change of route is not apparent, but froni any commanding summit in the neighborhood it may be seen that Easton is situated at the junction of two valleys, each of which has a width of nearly 2 miles. The chief difference in the valleys is that they are not at the same level. The Kachess Valley has an alti- 
tude of 2,150 feet, whereas the old floor of the Yakima Valley, represented by the tops of the hills above Easton, is 350 feet higher. It is clearly evident that for some reason the Kachess Valley has been deepened below that of Yakima River, and that the latter is now cutting a narrow trench in its old valley bottom in order to reduce its grade to that of the stream which it joins near Easton. These changes seem to be connected in some way with the occupation of the valleys by glacial ice, but the manner in which it has been accomplished has not been worked out.

Both the Northern Pacific and St. Paul roads follow the river through the narrow gorge above Easton, where the stream boils and tumbles over the rocky ledges toward the open valley below. The sand and gravel carried down by the stream are constantly grinding away the hard rocks, but it is a slow process, and many generations will pass before the obstruction is removed. The narrow gorge is short, and beyond it the railway enters the relatively open valley above.

As the Northern Pacific crosses the summit of the range near Stampede Pass, about 9 miles from Easton, it climbs at a steep grade. The St. Paul road, which is here on the right, crosses at Snoqualmie Pass, 11 miles farther north. A short distance beyond Easton the railway enters the great mass of andesitic lava flows and tuffs that in this region make up the great bulk of the Cascade Range.

From a scenic point of view the climb to the pass is not striking, for the traveler sees only rounded mountain slopes thickly covered with timber and the broad valley equally well protected by a tangle of dense vegetation. It is reported that bowlders of granite and similar rocks have been found perched on the mountain sides from 1,200 to 1,700 feet above the bottoms of the valleys. These indicate that at some early stage of the glacial epoch the glaciers were much more extensive than thev were at a later stage when the moraines nreviously descrihed 
After a long climb the railway reaches Martin, the last station on the east side of the range, and a short distance beyond turns sharply to the left and faces the east portal of the Stampede Martin. tunnel. At this point there are visible on the right Elevation 2,781 feet. St. Paul 1,823 miles. remnants of the old line, which wound up to the top of the mountain before the tunnel was built.

The Stampede tunnel is nearly 2 miles long. So many trains pass through it that great difficulty has been experienced in keeping it free from smoke and gas, but now an enormous fan has been installed at the west end, in a building which the westbound traveler will see on his right as the train emerges from the tunnel. It is expected that this fan will free the tunnel of smoke and gas in a very short time.

Stampede Pass has an elevation above sea level of about 3,600 feet, but the long tunnel enables the railway to cross the range at a much lower level. In order to maintain a regular grade Stampede.

Filevation 2,852 feet. St. Paul 1,826 miles. down the west side of the range, the track winds in and out and around spurs in a most confusing manner to one who is endeavoring to keep directions or to see the mountains. From Stampede two lines of rails are visible far below on the left, which seem to belong to another road, but later it appears that they are parts of a large loop which the Northern Pacific is forced to make in order to get down the mountain side.

The mountain slopes are generally smooth and round, and the thick mantle of trees and brush covers all except here and there a lava cliff or an old scar that marks the passage of some forest fire. ${ }^{1}$ The outlook is confined generally to the valley of Green River, which the railway descends, but at one place, if the weather is favorable, a fleeting glimpse may be caught of the towering white cone of Mount

1 The traveler from the train can get only a very imperfect idea of the character of the country, for he is looking at it from a position below the level of the mountain tops and hence can not see its upper surface. Although it is not possible to see much of the Cascade Range, a study of the contours on sheets 26 and 27 will show that the mountain summits on both sides of the railway are at nearly the same elevation, ranging from 4,000 to 6,000 feet above sea level. It will show also that the range is not sharp crested, like those in the vicinity of Helena and Butte, but a broad plateau which has been so cut into by the streams that its originally regular surface has disappeared, leaving only a labyrinth of narrow branching valleys and steep-sided hills.
Sheet 26 also shows the location, about 12 miles south of the Stampede tunnel, of Naches Pass (altitude 4,923 feet) and the old Naches trail, which was the first road to be opened across the Cascade Range north of Columbia River. The early explorers learned of this route from the Indians and utilized it in their wanderings around the headwaters of Yakima River. It was not, however, used to any great extent until the rush of homeseekers about 1850 made it desirable to find a shorter route to the Puget Sound ports than that by way of Fort Vancouver, on Columbia River. Accordingly in 1853 the Naches trail was made passable for wagons, though probably a pretty rough road, and many settlers found their way to the Sound by this route. 
Rainier. This view may be had on the right while rounding the extreme point of the loop about 2 miles west of Stampede. The mountain is in view only for a moment and then is hidden by the nearer slopes.

The rocks in the valley of Green River are the same as those seen on the east side. They consist of lava flows and beds of volcanic tuff that have been tilted in various directions. These rocks are known as the Keechelus andesitic series and most of them are of Miocene age. They represent the great floods of lava and fragmental material that were poured out before the Cascades were formed. They now form part of the broad platform upon which the great volcanic cones of Mount Rainier, Mount Adams, and Mount St. Helens are reared. The train runs down the mountain slope on the left side of Sunday Creek to the junction of that stream with Green River, which comes from the south. At present the road makes a long loop up Green River, but a new line is being constructed that will cut off this loop. The valley of Green River, as well as that of Sunday Creek, is broad and rounded and shows clearly that it has been cleared and modified by a glacier. The development, maximum extension, and retreat of the glaciers of this region are described below by Bailey Willis. ${ }^{1}$

${ }^{1}$ Glacial development began in the high mountains. The climate, at one time milder than that now existing, gradually though not continuously increased in severity. As cold seasons grew longer and warm ones shorter, snow banks in the shadows of high peaks increased in volume and drifts accumulated in hollows less protected from the sun. As they grew, the snow banks consolidated to ice, and. flowing downward. became glaciers. from the Olympic Mountains, on the west; a larger one gathered along the base of the Cascade Range, on the east; the largest flowed south from the area between Vancouver Island and the mainland of British Columbia and poured a great mass of ice westward into the Strait of Juan de Fuca and another into Puget Sound. Tongues of these piedmont glaciers advanced along the valleys until opposing ice streams met and coalesced. 
Although the railway is steadily descending as it follows Green River, the canyon grows no deeper, for the reason that the westward slope of the top of the plateau in which it is cut is

\section{Lester.}

Elevation 1,626 feet. Population 405.* St. Paul 1,839 miles.

Hot Springs (see sheet 27 , p. 196) was once a noted resort, with a large hotel on

\section{Hot Springs.}

Elevation 1,545 feet. St. Paul 1,841 miles. about the same as the grade of the stream. In the vicinity of Lester the stream flows about 3,000 feet below the tops of the highest hills on either side, and this depth is maintained for a considerable distance. the right of the track; but a number of years ago the hotel was destroyed by fire, and it has not been rebuilt. Green River is now utilized by the city of Tacoma for its water supply, and great care is exercised in keeping the stream free from pollution. The intake of the waterworks will be seen lower down the stream.

Below Hot Springs the timber was originally very heavy, but most of it has been cut off or burned, and the traveler can obtain a very inadequate idea of a virgin Washington forest from Maywood.

Flevation 1,347 feet. St. Paul 1,846 iniles. what he sees along this route. In many places, however, the second growth is very dense, and it would be difficult to force one's way through it. In this vicinity the traveler gets his first good view of the luxuriant growth of ferns that characterizes the forests of the coastal belt of Oregon and Washington. (See Pl. XXVI, p. 194.) The rocks, although much obscured by vegetation, are similar to the lava flows and breccias that occur near the summit of the range and also on Humphrey.

Elevation 1,224 feet. St. Paul 1,850 miles. the east side. In the Green River valley the rocks have been smoothed and rounded by the glaciers that formerly flowed down the valley and spread out on the plain below. The smooth and open character of the valley continues down as far as Eagle Gorge, but beyond that place the river enters a narrow, steep-walled canyon that in no

Eagle Gorge.

Elevation 1,110 feet. Population 304.* St. Panl 1,854 miles. respect resembles the valley higher up. The contour map shows that a broad valley continues below Eagle Gorge to Barneston, but that neither the river nor the railway follows it. From the arrangement of the valleys it is evident that Green River, at some time in the an epoch during which the ice melted earlier and more rapidly in the lowlands, later and lingeringly in the canyons of the ranges. The piedmont glaciers shrunk till they parted, and each mantled the foothills of $i$ ts parent range. The margins of the glaciers consisted of masses of stagnant ice buried beneath accumulations of gravel, sand, and loam, and hardy vegetation may have flourished in soil upon the ice. Rivers flowed on the glaciers, through tunnels in them, and from beneath them. Ice-bound lakes were formed in embayments of the hills. Changes succeeded one another frequently, and each phase of ice and stream and lake left a meager record of its existence in deposits of detritus. 


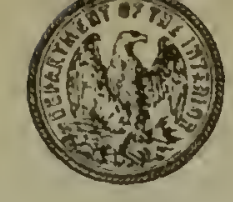

GEOLOGIC AND TOPOGRAPHIC MAP OF THE

NORTHERN PACIFIC ROUTE

From St. Paul, Minnesota, to Seattle, Washington

Base compiled from United States Geological Survey Atlas

Sheets, from railroad alignments and profiles supplied by

the Northern Pacific Railway Company and from additional

UNITED STATES GEOLOGICAL SURVEY

GEORGE OTIS SMITH, DIRECTOR

David White, Chief Geologist $\quad$ R. B. Marshall, Chief Geographer 1915

Each quadrangle shown on the map with a name in parenthesis in the
lower left corner is mapped in detail on the U.S C.S. Topographic
Sher lof

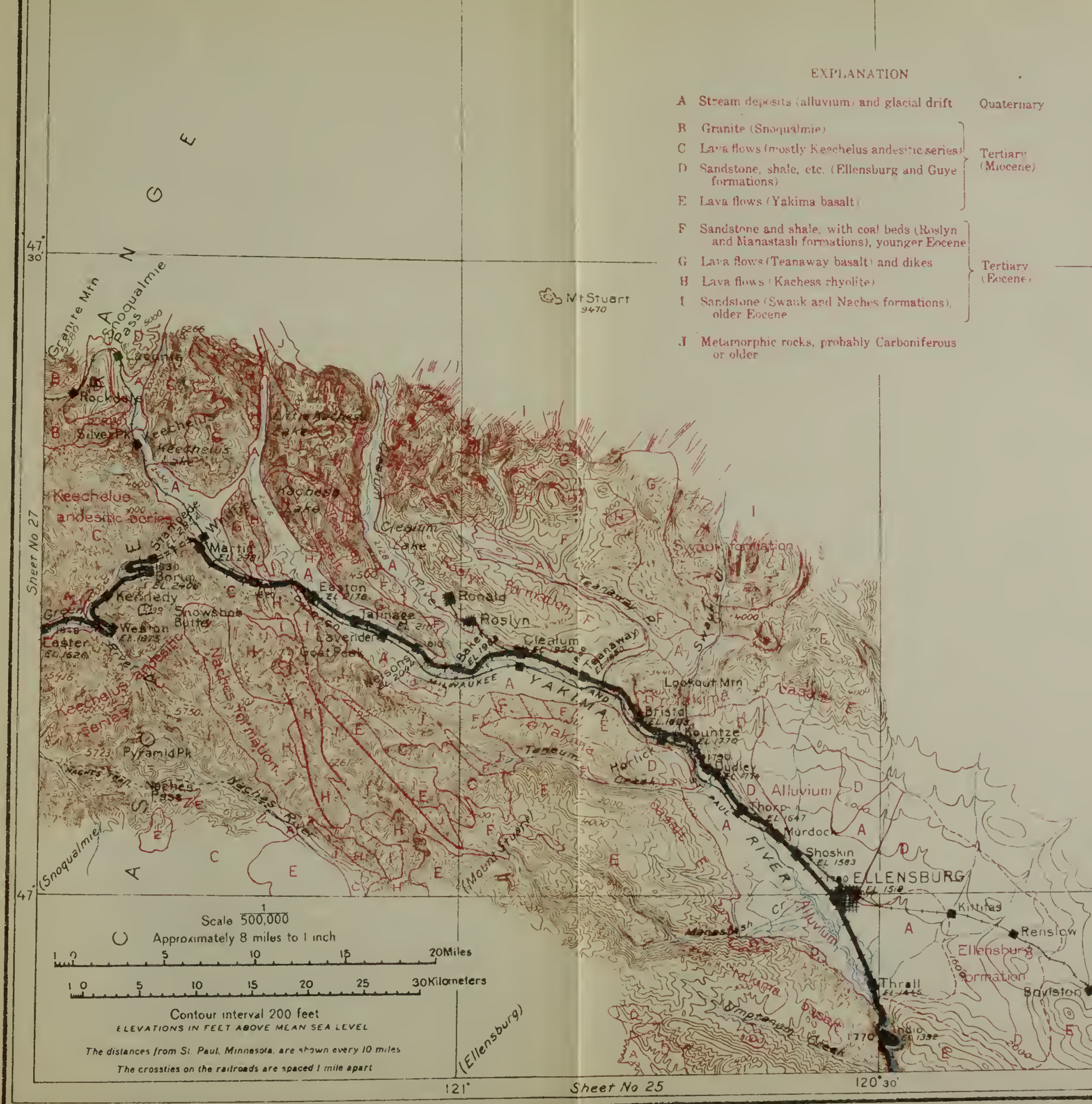



past, flowed in this valley instead of in its present course below Eagle Gorge. ${ }^{1}$

1 The old and new valleys of Green River afford an excellent example of changes that may take place in the drainage system of a country as a consequence of the invasion of a glacier. The river valleys on the west slope of the Cascade Mountains are in general well developed, showing that the streams have occupied them for a long time. The original course of Green River below Eagle Gorge was doubtless north by way of Page Mill and Barneston, for the present canyon below Eagle Gorge is so narrow that it must have been formed comparatively recently. The relative size of the two valleys is shown in figure 38 , which represents a cross section about 3 miles below Eagle Gorge.

To divert a stream intrenched in a valley from 2,000 to 3,000 feet deep must have required a formidable barrier. Such a barrier could have been produced only
The exact manner in which the ice blocked this outlet of Green River is a matter of speculation, but probably the glacier came down the Sound after the local glaciers in Green and Snoqualmie valleys had melted back from the mountain front and crowded up the valley of Green River until it completely blocked that valley with a great dam of ice, hundreds and possibly thousands of feet in thickness. This barrier seems to have been sufficient to raise the water of Green River until it flowed over a low divide that must have existed between the Green River valley and a small stream flowing to the west past Palmer Junction. Beyond this divide the river found an unobstructed outlet which it at once proceeded to deepen and which it finally cut below the level of the former outlet by Barneston. By the time the ice had disappeared



FIGURE 38.-Section showing size and shape of the valley of Green River below Eagle Gorge, Wash., compared with the valley the river abandoned when it was blocked by ice.

in one of four ways-(1) by a landslide $/$ Green River had become so deeply inwhich filled the valley below the point trenched in its new course that it per-

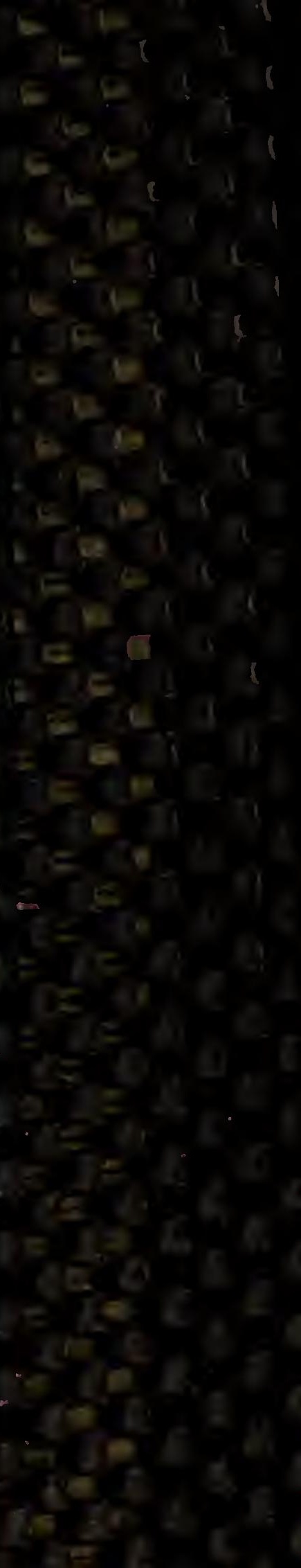


That part of the Green River valley below Eagle Gorge has all the features characteristic of newly cut gorges in fairly hard rocks. It is narrow and tortuous and the stream abounds in tumbling cascades and pools of deep water. It is a beautiful glen in which the rocks are covered with delicate mosses and draped with ferns whose graceful fronds sparkle with mist from the numerous cascades.

Just after passing milepost 81 the traveler can see the head gate of the Tacoma waterworks, and the deep-blue pool above, which certainly looks as if no polluting substances had ever affected it. After being accustomed to the water supplied to some of the eastern cities the traveler may envy these Pacific coast towns their nearness to mountain sources and the never-failing water supply they can procure there. Seattle also draws its supply of water from the Cascade Mountains, but as it is taken from Cedar River, the next stream on the right (north), neither the intake nor the conduit are visible from the train.

At Palmer Junction the Northern Pacific divides into two branches, the older line turning to the left (south) and going by way of Buckley to Tacoma, which at the time of the completion of the railway was its western terminus, and the other turning slightly to the right and going to Seattle by way of Auburn. ${ }^{1}$

1 The original plan of the Northern Pacific was to build on the north side of Columbia River from the mouth of Snake River to Kalama and thence northward to Puget Sound. That part of the road from Kalama to Tacoma was the first to be constructed, the first train reaching Tacoma on December 16, 1873. Financial difficulties forced a suspension of operations for some time, but in 1880 building was resumed and actively pushed from Mandan, N. Dak., westward and from the mouth of Snake River eastward. The line along Columbia River from Kalama to Snake River had not yet been touched, but it was thought that if the line east of Snake River could be completed, boat service on the river would accommodate the traffic until the company was strong enough financially to undertake the building of that line. In the meantime a franchise for the construction of a road along the south bank of the Columbia had been obtained by the Oregon Railway \& Navigation Co., and traffic arrangements had been entered into between this company and the Northern Pacific for the joint use of this line from Wallula to Portland. While these nego- tiations were under way the construction of the main line was carried on rapidly, and the last spike connecting the eastern and western sections was driven a little west of Garrison in September, 1883.

As early as 1876 a line was built from Tacoma up Puyallup River to the Wilkeson coal mine for the immediate purpose of procuring coal, and ultimately as a part of the Cascade branch, which the Northern Pacific, even at that early date, was considering a necessity. Work on this branch was suspended during the reorganization of the company in the years 1873-1879 and also while the company was bending all its energies to the completion of the main line in 1880 1883. Finally work was begun on this branch in earnest in 1884, but owing to the delay in constructing the Stampede Tunnel, the first train over the line did not reach Tacoma until July 3, 1887 . In 1883 the railroad from Seattle to Auburn and Puyallup was built by a company of local capitalists, but later it was taken over by the Northern Pacific. The last cut-off constructed was the road from Palmer Junction to Auburn, which now gives a direct line from St. Paul to Seattle. 
About a mile east of Palmer Junction the railway enters one of the productive coal fields of the State, though little coal or evidence of coal mining can be seen from the train. Several mines have been developed, however, south of the river, within a distance of 3 or 4 miles, and one or two mines to the north.

\section{Palmer Junction.}

Elevation 869 feet. St. Paul 1,862 miles.
Between Palmer Junction and Kanaskat the Northern Pacific is crossed by a branch of the St. Paul road which leads to several mining towns along the mountain front and terminates at Enumclaw, on the Tacoma line of the northern Pacific, 10 miles to the south. The mountains end abruptly at Kanaskat and give place to a The glacial drift on this plain is underlain by shale, and coal beds, which belong to the Puget group and which are of about the same age as the Roslyn (Eocene) formation on the other side of the Cascade Range, but few of the rocks are exposed at the surface. There are two large coal mines at Ravensdale, one of which can be seen on the left (south) as the train

passes through the village. ${ }^{1}$
As the presence of coal beds means that swamps prevailed at one time in this region, it is reasonable to suppose that vegetation flourished in that far-off time much as it does to-day. Careful search has shown that plants did grow luxuriantly then, and their fossil forms are so well preserved that the botanist has been able not only to distinguish the species that grew here, but to determine from the kind of plants the climate that must have prevailed. In the note below F. H. Knowlton compares the fossil flora with that living in Washington at the present time. ${ }^{2}$ 
West of Ravensdale the railway pursues a westerly course, crossing under the Columbia \& Puget Sound Railroad and then following in a general way a slight depression in the drift without any marked features of relief.

Beyond Covington the valley deepens and becomes more restricted, and the railway cuts show that the valley has been excavated in a thick deposit of glacial gravel. This material, Covington.

Elevation 361 feet. Population 145.* St. Paul 1,874 miles. known as the Orting gravel, was deposited by streams flowing from the ice front of the Admiralty glacier (see p. 192) after it had retreated to a position farther north.

At milepost 102 is the State fish hatchery, which supplies fish fry for many of the streams on this side of the mountains. Soon after passing this point the train crosses Green River and is once more in a

large and varied flora of not less than 2,500 species of the so-called higher plants alone. As these soil and climatic conditions vary from place to place, there are many sharp, almost abrupt changes in the character of the vegetation. Thus the Cascade Range, although only 6,000 or 7,000 feet high, constitutes an effective barrier which relatively few plants are able to cross. On the east side of the mountains there is an arid transition area where the sagebrush plains of Columbia River give way to the slightly higher, treeless, grass-covered zone known as the bunch-grass prairies. Still higher and nearer the mountains is the yellow-pine belt. Here the forests are composed mainly of the yellow or bull pine, with such undershrubs as the pinebark, buckbrush, roses, and a tall huckleberry.

On the western slope of the Cascades the change in the character of the vegetation is marked. The dominant forest tree is the red fir, which covers fully 90 per cent of the heavily timbered area, in places with a stand so dense that the sun can scarcely penetrate. In a narrow strip along the coast the dominant species is the Sitka or tideland spruce. In the bottom lands, mainly river valleys, the conspicuous trees or shrubs are the red cedar, giant cedar, white fir, large-leaved maple, Oregon ash, cottonword, western cornel, vine maple, crab apple, willows, the terrible devil's club, and salmonberry. On the gravelly prairies are the only species of oak growing in the State, as well as the black pine and, until the middle of July, a carpet of brilliant flowers.

The fossil flora of this region, found mainly in more or less close association with the numerous coal beds, was also an exceedingly rich and diverse one, numbering, as at present understood, about 350 species, with the probability that it may reach 400 or 500 species when fully known. Not a single one of these fossil species is now known to be living, although many of them belong to genera that are the same as or similar to those that make up the present flora. In view of the so-called accident of preservation, it is probable that the total fossil flora may have equaled the living flora in number of species.

The almost complete change in the character of the flora since the Puget epoch (Eocene) is well shown by the conifers. This group is now dominant in conspicuousness and number of individuals, whereas in Puget time it was almost negligible, being represented by only three kinds-cypress, cedar, and juniper-and these were so scarce that less than twenty examples out of many thousands of specimens have been observed. Another marked difference between the two floras is shown by the presence of palms in the Puget flora. Two very distinct kinds of palms have been found, one with rather small, feather-like leaves, and a liuge fan palm, with leaves that must have been at 
broad valley in which the timber has been cleared away and farms established. To one not accustomed to the thick forests of the Pacific slope, it is a relief to emerge from their dense shade and enter open country.

After crossing Green River and the broad valley in which it flows the train passes under a high bluff of gravel (Orting) on the south.

\section{Auburn.} Population 957.

St. Paul 1,883 miles.
Elevation 100 feet.

The origin and geologic age of this gravel, as well as of the other formations of the drift in Washington, are discussed below by W. C. Alden. ${ }^{1}$ This gravel has been extensively used by the railway for ballasting the track. At Auburn the railway line across the mountains unites with the line from Portland to Seattle. The rest of the route is directly north down the valley to its junction with Black River, which is the natural outlet of Lake Washington.

least 5 or 6 feet across. At present palms do not grow wild within a thousand miles of the Puget Sound region.

The traveler will doubtless be struck by the abundance of beautiful ferns now growing along the forest borders in the open, partly shaded locations. Ferns were also present during Puget time, though none that have been found are very closely related to the living forms. Tall, bushy horsetails (Equisetum) are conspicuous in many places, and the group was represented in the fossil flora. The deciduous-leaved plants, to judge from their fossil remains, were in the vast majority during Puget time and show much diversity. They included figs of several kinds, hackberries, mul- maples, dogwoods, sycamore, etc., in the upper beds of the group would seem to indicate an approach to the climatic conditions prevailing at present.

A number of fossil plants have been found to be common to the east and west sides of the Cascades. This would indicate that approximately similar conditions of climate and topography prevailed now exists, did not then intervene.

${ }^{1}$ At a time which probably corresponds to the last or Wisconsin stage of glaciation in the eastern part of the United States, the mountains of Washington were largely covered with ice, and the Vashon lobe of throughout this general area during the Puget epoch. The Cascade Range, as it 
Below the point of junction the stream is known as Duwamish River, and this the road follows to the tidal flats of Elliott Bay at Seattle.

The broad valley at Auburn is distinctly different from the ordinary stream valleys of this region, in that it is wider than is required by such streams as now occupy it, it is flatter than valleys excavated by erosion, and it is open to tidewater at both ends-Elliott Bay (Seattle) on the north and Commencement Bay (Tacoma) on the west. The floor of the valley is so flat that streams entering it build delta-like accumulations of sediment upon which the stream channel shifts from place to place. White River, next to Green River on the south and named because of the milky color of its water, derived from the glaciers of Mount Rainier, enters the valley a few miles above Auburn. Part of the stream at times turns south into Puyallup (poo-yal'up) River and reaches tidewater at Tacoma and the other part flows north and unites with Green River. The arrangement of the valleys and their peculiar connection with bays and similar indentations of the coast line strongly suggest that at one time this entire valley from Tacoma to Seattle was an arm of the Sound similar to but smaller than Admiralty Inlet and that it has become a land valley simply by being filled with sediment brought down by the rivers from the Cascade Mountains.

Bailey Willis, who has made a careful study of the Puget Sound region, is of the opinion that the peculiar branching channels of the Sound could have been produced only by the submergence of a land on which a branching river system had formerly existed. If this view is correct, it is evident that many modifications must have been made, for a peculiarity of the channels of the Sound is that they not only unite as the tributaries of a river system unite, but they separate in a most intricate fashion. Taken as a whole, the conclusion appears well founded, but there are many minor points that still remain to be explained.

to fill the deep depressions, so that when free of ice these were occupied by marine waters. This drift is underlain by stratified sand and gravel (Douty gravel, Puyallup sand, and Orting gravel) deposited by waters from the melting of earlier glaciers. These deposits include lignite, formed from vegetation which grew upon the sand and gravel, and they are much weathered and eroded, showing that they were exposed during a long interglacial stage before being overridden and covered by the deposits of the glaciers mentioned above.
Beneath these sands and gravels lie deposits of stiff blue clay, mostly stratified but locally filled with subangular stones and large bowlders. These deposits, known as the Admiralty till, deposited by the Admiralty glacier, were laid down during an earlier stage of glaciation, when the Puget Sound basin was occupied by a lobe of the Cordilleran ice sheet, as at the Vashon stage. There are some suggestions that still earlier glaciers occupied the basin, but these are too indefinite to be given much weight. 
The White River valley is largely given up to truck farming and lairying. The dairying industry centers about Kent, where there is a large plant for the manufacture of condensed milk. On the left (west) are the lines of the OregonWashington Railroad \& Navigation Co., the St. Paul road, and the Interurban Electric Co.; on the right the town of Renton, perched partly on the hillside,

Kent.

Elevation 53 feet. ?opulation 1,908 . t. Paul 1,888 miles. ibout 2 miles distant. This is another coal-mining town-in fact, coal mining is the chief business in many parts of the country back rom the Sound. Renton is nearer tidewater than the other mining owns of the State, and the coal mined here has a fine reputation in he cities on the Sound as a clean fuel for domestic use. ${ }^{1}$

Between mileposts 11 and 10 the Black River branch on the right eads to Renton and other towns in that direction, and at milepost 10 the Renton branch of the interurban trolley line crosses the St. Paul road and then crosses Black River, which is the outlet of Lake Washington. Beyond the crossing of Black River the railway is at he foot of the bluffs on the right side of the valley, and the hillside cuts expose, in several places, sandstone and shale (Puget group), out no coal beds occur in this part of the formation. This part of the valley is known as the Duwamish Valley. At its lower end the stream $\mathrm{s}$ actively engaged in filling the bay with the sediment which it caries. The work of the stream has been supplemented in recent years by civic activity in cutting down some of Seattle's hills and in reducing the grades in the business part of the city. On some of the streets the grade was lowered as much as 30 feet, and on others there was a corresponding fill. As the material on which the city is built is glacial drift, steam shovels were largely used for the excavation, but the methods used in hydraulic mining were employed to get rid of the Iarce hill unon which the old Washinoton Hotel was situlated The rail- 
The most important natural feature at Seattle is the wonderful harbor, with deep water at the very door of the city. The depth of water is shown on the small map on sheet 27 . Other

Seattle.

Elevation 24 feet. Population 237,194. St. Paul 1,904 miles.

features of interest are the steep water front and the way in which it has been modified and shaped for the use of man, and Lake Washington, which bounds the city on the east and is soon to be thrown open to the commerce of the world by the construction of a ship canal from Salmon Bay through Lake Union and across the narrow neck of land south of the State University. This will greatly increase the harbor facilities, and the fresh water of the lake will afford an efficient means of freeing ocean-going vessels of barnacles.

The State University is beautifully situated on the shore of Lake Washington, and its campus was utilized for the site of the AlaskaYukon-Pacific Exposition in 1909. The city is well supplied with parks and connecting boulevards, and one of the finest views about the city is that of Mount Rainier ${ }^{1}$ from the boulevard that follows the shore of Lake Washington.

${ }^{1}$ Of all the mountain masses and rugged snow peaks in the region described in this book, none will compare with the beautiful majestic cone of Mount Rainier (Pl. XXVII). This mountain giant is the dominating feature of this part of the Pacific slope. There may be other snowclad peaks that seem to pierce the sky, such as Adams, Baker, and St. Helens, but these are dwarfed beside the mighty symmetrical cone of Rainier.

Mount Rainier (14,408 feet) is of about the same height as Pikes Peak, in Colorado (14,108 feet), or Mount Whitney, in California (14,502 feet), but it is superior in beauty to either, for it is not only a symmetrical cone but it can be seen from sea level and at close range, so that it stands out in all its massive grandeur. Mount Rainier when it comes into view from Tacoma, Seattle, or any other point along the winding channels of Puget Sound or from Lake Washington, reveals its full height, as there are no other peaks to obstruct the view or to detract from its commanding presence.

The early exploration of the Puget Sound region is a matter of some uncertainty and doubt. Apostolos Valerianus, an old Greek pilot in the service of Spain, better known by his Spanish sobriquet
Juan de Fuca, claimed to have discovered the main entrance to the Sound about 1600 , but grave doubt has been cast upon his narrative and many believe that his account was pure fiction. The first reliable account of the Sound was written by Capt. George Vancouver, of the British Royal Navy, who in 1792 mapped the Sound, named it after Peter Puget, one of his lieutenants, and also named many other natural features of the region, including Mount Rainier.

It is said that the original Indian name was Tacoma or Tahoma, meaning "big snow mountain," but Vancouver disregarded or did not know of the Indian usage and named the peak after Rear Admiral Rainier, of the British Navy. This name has been adopted by the United States Geographic Board. Nevertheless, there are many people who would gladly see the foreign name abandoned, even though usage has given it great weight, and the aboriginal name Tacoma revived.

Naturally, the high peaks of the Cascade attracted the attention of everyone who entered the region, and many were eager to scale them. The earliest record of mountain climbing was the ascent of Mount St. Helens in 1853. During the 


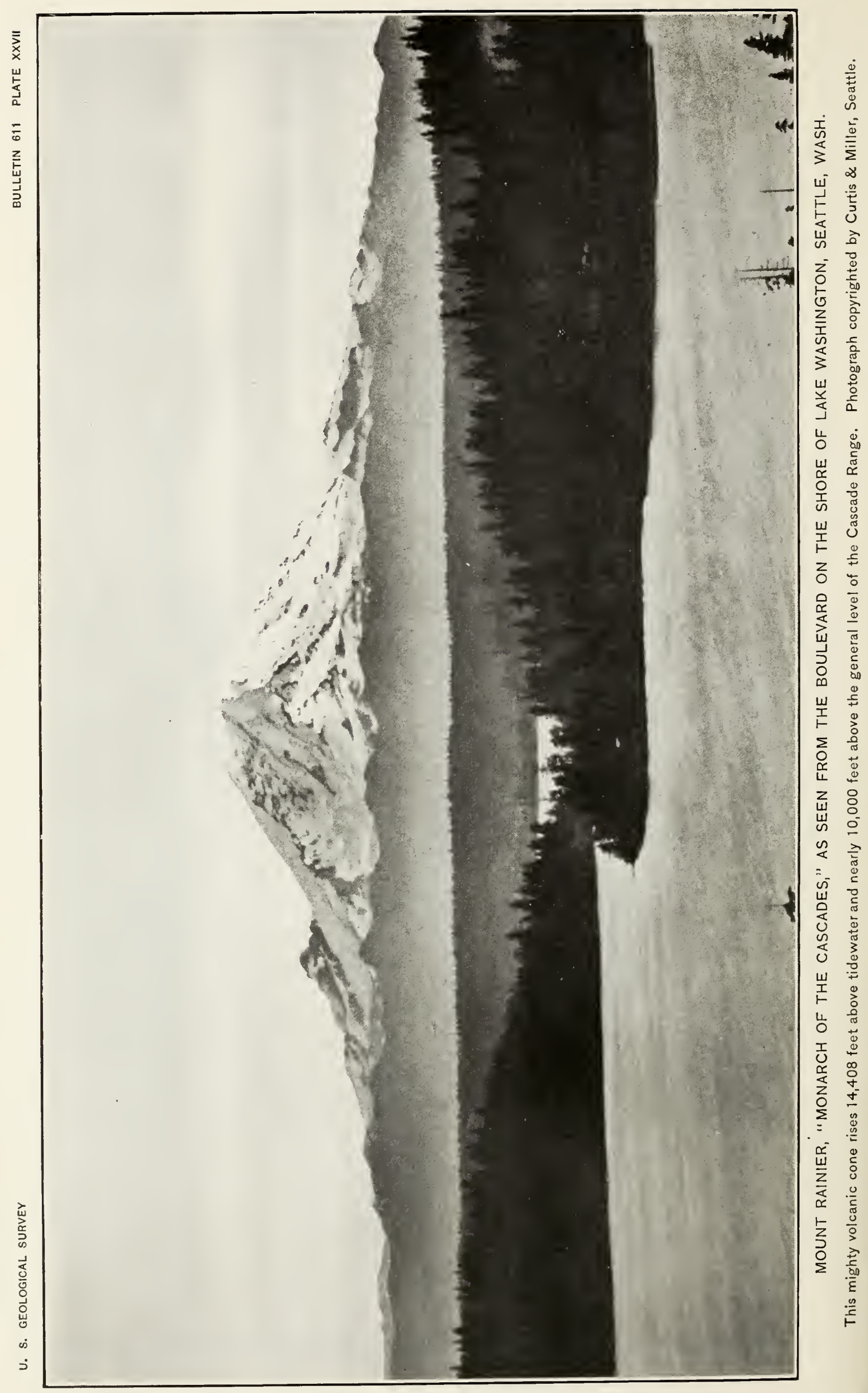


Although Capt. Vancouver mapped and named Puget Sound in 1792, there was no permanent settlement or even trading post in the region until 1833, when Fort Nisqually was built by the Hudson's Bay Co. on the ground now occupied by the city of Tacoma. This post was for many years, even up to the time it was purchased by the United States Government in 1869, the leading commercial place on the Sound and was surpassed only on the northwest coast by Fort Vancouver, on the Columbia, which was the headquarters of the Hudson's Bay Co. Capt. Wilkes, when on his exploring expedition of 1840, landed at Fort Nisqually and sent a party inland to explore the country tributary to the Sound and to Columbia River. One party traveled southward and explored the Willamette (Wil-lam'et) Valley of Oregon, and another, under Lieut. R. W. Johnson, on May 29, 1840, crossed the Cascade Mountains by way of Naches Pass. This seems to have been the earliest passage by white men across the Cascades. At that time it was only an Indian trail, but in 1853 a road was cleared so that emigrants over the old Oregon Trail could make a short cut to the Sound instead of having to keep to the south along Columbia River.

following year parties reached the summits of Mount Hood, in Oregon, and Mount Adams. Several unsuccessful attempts were made to climb Mount Baker, but not until 1868 did a party reach the top.

Lieut. A. V. Kautz made an almost successful ascent of Mount Rainier in 1857, reaching within 1,000 feet of the summit. His trip, however, proved to be very important, for he established the existence of glaciers here, which up to that time had not been known in this country. reached from either Seattle or Tacoma, and the views obtained on such a trip will amply repay anyone for the journey.

Mount Rainier, like Mounts Adams, St. Helens, and Baker, and Glacier Peak, is a great volcanic cone built upon the summit of the Cascade Range by successive layers of material thrown out of its crater. The great height of these peaks has not been materially reduced by erosion, for the time since their formation has not been long enough to permit very effective work by the elements. Steam escapes from 
The first settlement in the vicinity of Seattle was made at Alki Point in 1851. This was named New York, to which somebody facetiously added the Chinook word "alki," meaning "by and by." On February 15, 1852, the claims which became the town site of Seattle were staked, but up to 1860 there were not more than 20 families in the town. The town of Tacoma was laid out in 1872, and since that date there has been the most intense though friendly rivalry between the two places.

The Puget Sound basin lies in what is called the moist district of Washington. It has an annual precipitation of 25 to 60 inches, threefourths of which occurs in the "wet season," from November to April. It is therefore intermediate between the extremely wet country of the coast, having an annual precipitation of 60 to 120 inches, and the dry belt east of the Cascade Mountains, where the annual precipitation is only 8 or 10 inches. The Puget Sound region is regarded by many unfamiliar with it as a region of excessive rainfall, but the figures given by the Weather Bureau show that the precipitation here is about the same as in southern Ohio. The mean annual temperature of Seattle for December, 1894 , to December, 1903 , was $52^{\circ}$. The maximum for that time was $96^{\circ}$ and the minimum $3^{\circ}$.

Although the great forests that have made this part of the northwest coast famous are fast disappearing, lumbering continues to be the chief industry along the Sound, and millions of feet of lumber are each year sent east by the railways or shipped by vessel to various parts of the world.

Seattle has one of the finest deep-water harbors on the coast. As shown by the sketch map of Elliott Bay on sheet 27, the water deepens rapidly to 100 feet and then the depth increases gradually and somewhat irregularly to 600 feet where the bay opens into the Sound.

The harbor facilities of Seattle and its position near the Strait of Juan de Fuca and also the inland passage to the north have made it the most advantageous place on the northwest coast for the center of the Alaskan trade and also for a large part of the oriental commerce to the United States. 



\section{IMPOR'TAN'T PAPERS ON THE GEOGRAPHY, GEOLOGY,}

AND HISTORY OF THE REGION TRAVERSED BY THE NORTHERN PACIFIC RAILWAY.

MINNESOTA.

Coues, Elliott, The explorations of Zebulon M. Pike, vol. 1, New York, 1895.

NORTH DAKOTA.

Hall, C. M., and Willard, D. E., U. S. Geol. Survey Geol. Atlas, Casselton-Fargo folio (No. 117), 1905.

Leonard, A. G., U. S. Geol. Survey Geol. Atlas, Bismarck folio (No. 181), 1912.

Leonard, A. G., and Smith, C. D., The Sentinel Butte lignite field, North Dakota and Montana: U. S. Geol. Survey Bull. 341, pp. 15-35, 1909.

Todd, J. E., The moraines of the Missouri Coteau and their attendant deposits: U. S. Geol. Survey Bull. 144, 1896.

Upham, Warren, The glacial Lake Agassiz: U. S. Geol. Survey Mon. 25, 1896.

Willard, D. E., U. S. Geol. Survey Geol. Atlas, Jamestown-Tower folio (No. 168), 1909.

\section{MONTANA.}

Barrell, Joseph, Geology of the Marysville mining district, Mont.: U. S. Geol. Survey Prof. Paper 57, 1907.

Calkins, F. C., and MacDonald, D. F., A geological reconnaissance in northern Idaho and northwestern Montana: U. S. Geol. Survey Bull. 384, 1909.

Calvert, W. R., Geology of certain lignite fields in eastern Montana: U. S. Geol. Survey Bull. 471, pp. 187-201, 1912.

The Livingston and Trail Creek coal fields, Park, Gallatin, and Sweetgrass counties, Mont.: U. S. Geol. Survey Bull. 471, pp. 384-405, 1912.

The Electric coal field, Park County, Mont.: U. S. Geol. Survey Bull. 471, pp. $406-422,1912$.

Chittenden, H. M., The Yellowstone National Park: Cincinnati, The Robert Clarke Co., 1895.

Collier, A. J., and Smitr, C. D., The Miles City coal field, Mont.: U. S. Geol. $\mathrm{S}_{1 \text { rurov }} \mathrm{B}_{111} \quad 341$ nn $36-61 \quad 1009$ 
Ween, W. H., Geology and ore deposits of the Butte district, Mont.: U. S. Geol. Survey Prof. Paper 74, 1912.

The glaciation of the Yellowstone Valley north of the park: U. S. Geol. Survey Bull. 104, 1893.

The Laramie and the overlying Livingston formation in Montana, with report on flora, by F. H. Knowlton: U. S. Geol. Survey Bull. 105, 1893.

Weed, W. H., Emmons, S. F., and Tower, G. W., jr., U. S. Geol. Survey Geol. Atlas, Butte special folio (No. 38), 1897.

Woodruff, E. G., The Red Iodge coal field, Mont.: U. S. Geol. Survey Bull. 341, pp. 92-107, 1909.

\section{IDAHO.}

Ransome, F. L., and Calkins, F. C., The geology and ore deposits of the Coeur d'Alene district, Idaho: U. S. Geol. Survey Prof. Paper 62, 1908.

WASHINGTON.

Bretz, J. П., Glaciation of the Puget Sound region: Washington Geol. Survey Bull. 8, 1913.

CALKINs, F. C., Geology and water resources of a portion of east-central Washington: U. S. Geol. Survey Water-Supply Paper 118, 1905.

Evans, G. W., The coal fields of King County, Wash.: Washington Geol. Survey Bull. $3,1912$.

Russell, I. C., A geological reconnaissance in central Washington: U. S. Geol. Survey Bull. 108, 1893.

Russeli, I. C., and Smitr, G. O., Glaciers of Mount Rainier, with a paper on the rocks of Mount Rainier: U. S. Geol. Survey Eighteenth Ann. Rept., pt. 2, pp. 349424, 1898.

Sмiтн, E. E., Coals of the State of Washington: U. S. Geol. Survey Bull. 474, 1911.

Sмгтн, G. O., Geology and water resources of a portion of Yakima County, Wash.: U. S. Geol. Survey Water-Supply Paper 55, 1901.

- U. S. Geol. Survey Geol. Atlas, Ellensburg folio (No. 86), 1903.

U. S. Geol. Survey Geol. Atlas, Mount Stuart folio (No. 106), 1904.

Smith, G. O., and Calkins, F. C., U. S. Geol. Survey Geol. Atlas, Snoqualmie folio (No. 139), 1906.

Smith, G. O., and Willis, Bailey, Contributions to the geology of Washington: U. S. Geol. Survey Prof. Paper 19, 1903.

WARING, G. A., Geology and water resources of a portion of south-central Washington: U. S. Geol. Survey Water-Supply Paper 316, 1913.

Willis, Bailey, and Smith, G. O., U. S. Geol. Survey Geol. Atlas, Tacoma folio (No. 54), 1899.

\section{GENERAL.}

Coues, Elliott, History of the expedition under the command of Lewis and Clark, 4 vols., New York, Francis P. Harper, 1893.

Gannett, Henry, Boundaries of the United States and the several States and Territories, with an outline of the history of all important changes of territory: U. S. Geol. Survey Bull. 226, 1904.

Smalley, E. V., History of the Northern Pacific Railroad, New York, G. P. Putnam's Sons, 1883.

Wheeler, O. D., The trail of Iewis and Clark, G. P. Putnam's Sons, New York, 1904. 


\section{GLOSSARY OF GEOLOGIC TERMS.}

Alluvial fan. The outspread sloping deposit of bowlders, gravel, and sand left by a stream where it passes from a gorge out upon a plain.

Andesite. A lava of widespread occurrence, usually of dark-gray color and intermediate in chemical composition between rhyolite and basalt.

Anticline. Arch of bedded or layered rock suggestive in form of an overturned canoe. (See fig. 20, p. 102.) (See also Dome and Syncline.)

Badlands. A region nearly devoid of vegetation where erosion, instead of carving hills and valleys of the familiar type, has cut the land into an intricate maze of narrow ravines and sharp crests and pinnacles. Travel across such a region is almost impossible, hence the name. (See Pls. VI-IX, pp. 62-63.)

Basalt. A common lava of dark color and of great fluidity when molten. Basalt is less siliceous than granite and rhyolite, and contains much more iron, calcium, and magnesium.

Bolson (pronounced bowl-sown'). A flat-floored desert valley that drains to a central evaporation pan or playa.

Bomb. See Volcanic bomb.

Breccia (pronounced bretch'a). A mass of naturally cemented angular rock fragments.

Crystalline rock. A rock composed of closely fitting mineral crystals that have formed in the rock substance as contrasted with one made up of cemented grains of sand or other material or with a volcanic glass.

Diabase. A heavy, dark, intrusive rock having the same composition as basalt, but, on account of its slower cooling, a more crystalline texture. Its principal constituent minerals are feldspar, augite, and usually olivine. Olivine is easily changed by weathering, and in many diabases is no longer recognizable. Augite is a mineral containing iron and magnesium and is similar to hornblende.

Dike. A mass of igneous rock that has solidified in a wide fissure or crack in the earth's crust. (See fig. 15, p. 95.)

Diorite. An even-grained intrusive igneous rock consisting chiefly of the minerals 
Fault. A fracture in the earth's crust accompanied by movement of the rock on one side of the break past that on the other. If the fracture is inclined and the rock on one side appears to have slid down the slope of the fracture the fault is termed a normal fault. If, on the other hand, the rock on one side appears to have been shoved up the inclined plane of the break, the fault is termed a reverse fault. (See fig. 20, p. 102; fig. 23, p. 112, and fig. 30, p. 143.)

Fault block. A part of the earth's crust bounded wholly or in part by faults.

Fault scarp. The cliff formed by a fault. Most fault scarps have been modified by erosion since the faulting.

Fauna. The animals that inhabited the world or a certain region at a certain time.

Fissure. A crack, break, or fracture in the earth's crust or in a mass of rock.

Flood plain. The nearly level land that borders a stream and is subject to occasional overflow. Flood plains are built up by sediment left by such overflows.

Flora. The assemblage of plants growing at a given time or in a given place.

Fold. A bend in rock layers or beds. Anticlines and synclines are the common types of folds. (See fig. 28, p. 129, and fig. 31, p. 144.)

Formation. A rock layer, or a series of continuously deposited layers grouped together, regarded by the geologist as a unit for purposes of description and mapping. A formation is usually named from some place where it is exposed in its typical character. For example, Denver formation, Niobrara limestone.

Fossil. The whole or any part of an animal or plant that has been preserved in the rocks or the impression left by a plant or animal. This preservation is invariably accompanied by change in substance, and from some impressions the original substance has all been removed. (See Pls. VI, A, p. 62; XI, B, p. 75.)

Gneiss (pronounced nice). A rock resembling granite, but with its mineral constituents so arranged as to give it a banded appearance. Most gneisses are metamorphic rocks derived from granite or other igneous rocks.

Granite. A crystalline igneous rock that has solidified slowly deep within the earth. It consists chiefly of the minerals quartz, feldspar, and one or both of the common kinds of mica, namely, black mica, or biotite, and white mica, or muscovite. The feldspar is the kind known as orthoclase, and may be distinguished from quartz by its pale-reddish tint and its property of breaking with flat shining surfaces (cleavage), for quartz breaks irregularly. The micas are easily recognized by their cleavage into thin, flexible flakes and their brilliant luster.

Horizon. In geology any distinctive plane traceable from place to place in different exposures of strata and marking the same period of geologic time. A particular horizon may be characterized by distinctive fossils.

Igneous rocks. Rocks formed by the cooling and solidification of a hot liquid material known as magma, that has originated at unknown depths within the earth. Those that have solidified beneath the surface are known as intrusive rocks, or, if the cooling has taken place slowly at great depth, as plutonic intrusive or plutonic rocks. Those that have flowed out over the surface are known as effusive rocks, extrusive rocks, or lavas. The term volcanic rocks includes not only lavas but bombs, pumice, tuff, volcanic ash, and other fragmental materials or ejecta thrown out from volcanoes.

Lithologic. Pertaining to lithology, or the study of rocks. (Sce also Petrology.) Pertaining to rock character.

Lode. An ore-bearing vein (see Vein); especially a broad or complex vein.

Loess (pronounced lurse with the $\mathrm{r}$ obscure). A fine homogeneous silt or loam showing usually no division into layers and forming thick and extensive deposits in the Mississippi Valley and in China. It is generally regarded as in part at least a deposit of wind-blown dust. 
Meander. To flow in serpentine curves. A loop in a stream. The term comes from the Greek name of a river in Asia Minor, which has a sinuous course. Most streams in flowing across plains develop meanders. (See Pl. III, A, p. 11.)

Metamorphism. Any change in rocks effected in the earth by heat, pressure, solutions, or gases. A common cause of the metamorphism of rocks is the intrusion into them of igneous rocks. Rocks that have been so changed are termed metamorphic.

Monzonite. An even-grained intrusive igneous rock intermediate in character between diorite and granite. It resembles granite.

Moraine. A mass of drift deposited by a glacier at its end or along its sides.

Oil pool. An accumulation or body of oil in sedimentary rock that yields petroleum on drilling. The oil occurs in the pores of the rock and is not a pool or pond in the ordinary sense of these words.

Outcrop. That part of a rock that appears at the surface. The appearance of a rock at the surface or its projection above the soil.

Paleontology. The study of the world's ancient life, either plant or animal, by means of fossils.

Peneplain. A region reduced almost to a plain by the long-continued normal erosion of a land surface. It should be distinguished from a plain produced by the attack of waves along a coast or the built-up flood plain of a river.

Petrography. The description of rocks, especially of igneous and metamorphic rocks, studied with the aid of the microscope.

Petrology. The study of rocks, especially of igneous and metamorphic rocks.

Placer deposit. A mass of gravel, sand, or similar material resulting from the crumbling and erosion of solid rocks and containing particles or nuggets of gold, platinum, tin, or other valuable minerals, which have been derived from rocks or veins by erosion.

Playa (pronounced plah'ya). The shallow central basin of a desert plain, in which water gathers after a rain and is evaporated.

Porphyry. Any igneous rock in which certain crystal constituents are distinctly visible in contrast with the finer-grained substance of the rock.

Quartzite. A rock composed of sand grains cemented by silica into an extremely hard mass.

Rhyolite. A lava, usually of light color, corresponding in chemical composition to granite. The same molten liquid that at great depth within the earth solidifies as granite would if it flowed out on the surface, cool more auicklv and crvstal- 
Slate. A rock that by subjection to pressure within the earth has acquired the property of splitting smoothly into thin plates. The cleavage is smoother and more regular than the splitting of schist along its grain.

Stratigraphy. The branch of geologic science that deals with the order and relations of the strata of the earth's crust.

Strike. The direction along which an inclined rock layer would meet the earth's surface if that surface were level. The outcrop (which see) of a bed on a plain is coincident with its strike.

Structure. In geology the forms assumed by sedimentary beds and igneous rocks that have been moved from their original position by forces within the earth or the forms taken by intrusive masses of igneous rock in connection with effects produced mechanically on neighboring rocks by the intrusion. Folds (anticlines and synclines) and faults are the principal mechanical effects considered under structure. Schistosity and cleavage are also structural features.

Syncline. An inverted arch of bedded or layered rock suggestive in form of a canoe. (See fig. 28, p. 129.)

Talus (pronounced tay'lus). The mass of loose rock fragments that accumulates at the base of a cliff or steep slope. (See P1. XXII, B, p. 166.)

Terrace. A steplike bench on a hillside. Most terraces along rivers are remnants of valley bottoms formed when the stream flowed at higher levels. Other terraces have been formed by waves. Some terraces have been cut in solid rock, others have been built up of sand and gravel, and still others have been partly cut and partly built up. (See Pl. XX, p. 142.)

Till. The deposit of mingled bowlders, rock fragments, and soil left behind by a melting glacier or deposited about its margin.

Tuff. A rock consisting of a layer or layers of lava particles blown from a volcano. A fine tuff is often called volcanic ash and a coarse tuff is called breccia.

Type locality. The place at which a formation is typically displayed and from which it is named; also the place at which a fossil or other geologic feature is displayed in typical form.

Unconformity. A break in the regular succession of sedimentary rocks, indicated by the fact that one bed rests on the eroded surface of one or more beds which may have a distinctly different dip from the bed above. An unconformity may indicate that the beds below it have at some time been raised above the sea and have been eroded. In some places beds thousands of feet thick have been washed away before the land again became submerged and the first bed above the surface of unconformity was deposited. If beds of rock may be regarded as leaves in the volume of geologic history, an unconformity marks a gap in the record.

Vein. A mass of mineral material that has been deposited in or along a fissure in the rocks. A vein differs from a dike in that the vein material was introduced gradually by deposition from solution whereas a dike was intruded in a molten condition.

Volcanic bomb. A rounded mass of lava thrown out while in a hot and pasty condition from a volcano. A bomb, like a raindrop, is rounded in its passage through the air and may be covered with a cracked crust due to quick cooling.

Volcanic cone. A mountain or hill, usually of characteristic conical form, built up around a volcanic vent. The more nearly perfect cones are composed principally of lava fragments and volcanic ashes.

Volcanic glass. Lava that has cooled and solidified before it has had time to crystallize. 




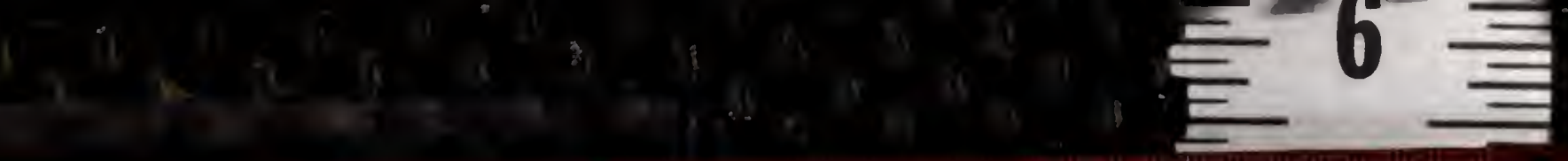

\section{ILLUSTRATIONS.}

\section{ROUTE MAP.}

For the convenience of the traveler the sheets of the route map are so folded and placed that he can unfold them one by one and keep each one in view while he is reading the text relating to it. A reference in parentheses is given in the text at each point where a new sheet should be unfolded.

SheEt 1. St. Paul to Cable, Minn......

2. St. Cloud to Verndale, Minn. (with map of Cuyuna iron range)...

3. Wadena to Hawley, Minn. (with map of western and Superior ice

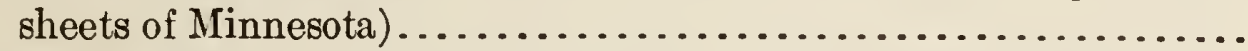

4. Hawley, Minn., to Buffalo, N. Dak. (with map of glacial Lake

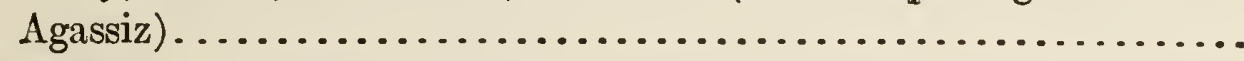

5. Tower City to Berner, N. Dak. (with map showing moraines formed by the ice sheet that crossed North Dakota in Wisconsin time)....

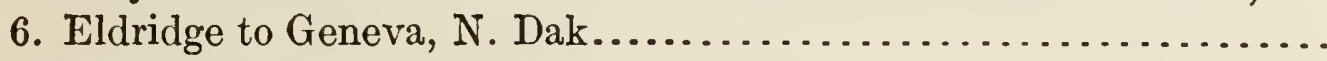

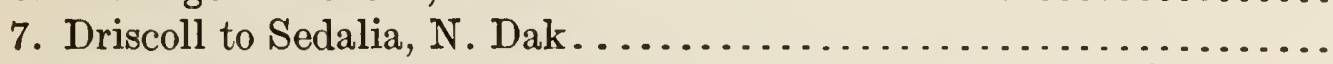

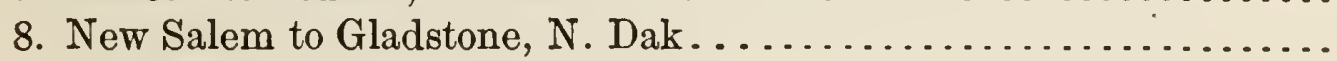

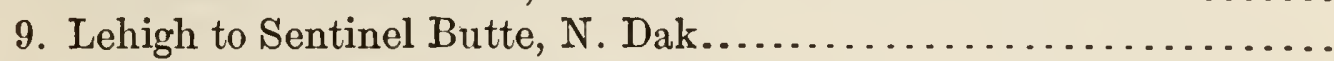



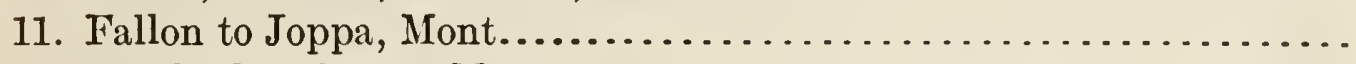

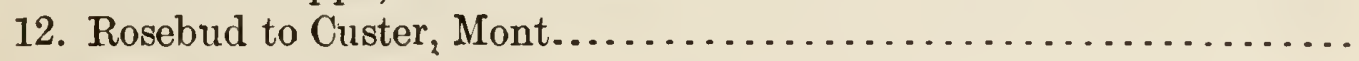



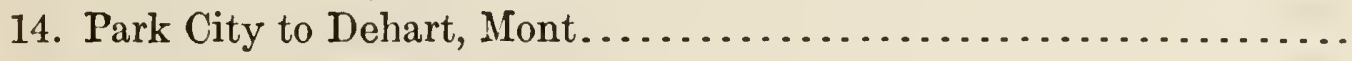

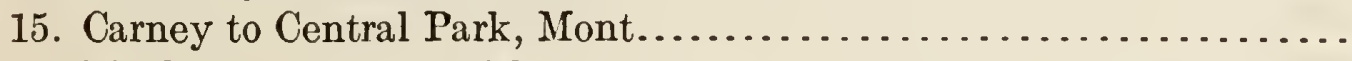



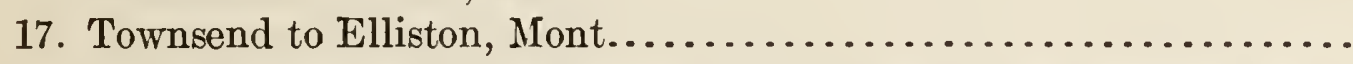

18. Warm Springs to Clinton, Mont. (with map of western Montana showing distribution of known Tertiary lake beds)............... 
PLATES.

Plate I. Relief map showing surface features of the western part of the United

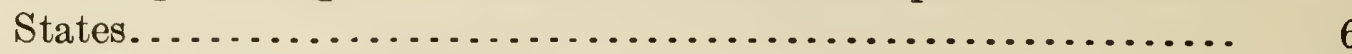

II. Minnehaha, "Laughing Water" ......................... 10

III. $A$, Valley City, N. Dak., from the "high line"; $B$, The "high line" across the valley of Sheyenne River, N. Dak................

IV. $A$, Badlands in the vicinity of Mandan, N. Dak.; $B$, Cracks produced

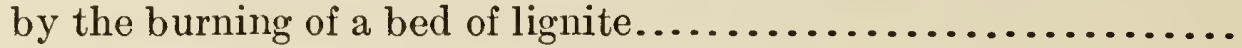

V. $A, B$, Erosion forms of North Dakota.......................

VI. $A$, Silicified stump in Pyramid Park, N. Dak.; $B$, The "prow of the battleship," one of the buttes of Pyramid Park, N. Dak..........

VII. $A$, View of the badlands of North Dakota; $B, \mathrm{~A}$ bed of lignite 15 feet thick in the canyon of Little Missouri River, N. Dak...........

VIII. $A, B$, Views of the badlands of North Dakota.................

IX. $A-D$, Views of the badlands of North Dakota and Montana.........

$\mathrm{X}$. The great Triceratops, which in Lance time roamed through the forests of Montana and North Dakota.........................

XI. A, Bluffs of Lance formation on Yellowstone River west of Hysham, Mont.; $B$, Fossil palm leaf of Eocene age found near Hysham,

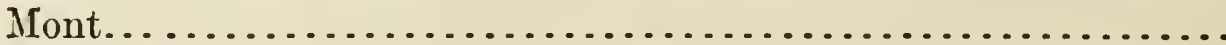

XII. $A, B$, Views in the sheep range of Montana...................

XIII. A, Pompeys Pillar, Mont., as seen from the Northern Pacific Railway; $B$, Inscription made by Capt. Clark on Pompeys Pillar, July $25,1806 \ldots \ldots \ldots \ldots \ldots \ldots \ldots \ldots \ldots \ldots \ldots \ldots \ldots \ldots \ldots \ldots \ldots \ldots \ldots \ldots \ldots$

XIV. Emigrant Peak, the sentinel guarding the northern approach to

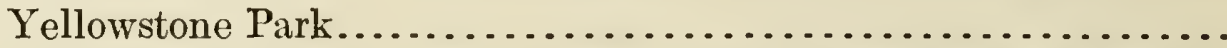

XV. Rocky gateway which Rock Creek has cut through the Madison limestone below Chestnut, Mont.......................

XVI. View looking west from Homestake summit, Mont...............

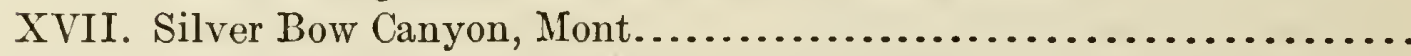

XVIII. Cliffs of Madison limestone at Lombard, Mont.................

XIX. $A$, Summer camp of the Flathead Indians, a familiar scene in the Jocko Valley, Mont.; $B$, Glacier on the north slope of McDonald

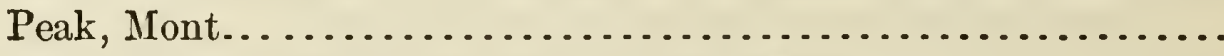

XX. View down Flathead River from Knowles, Mont...............

XXI. Cabinet Gorge, Idaho. . . . . . . . . . . . . . . . . . . . . . . . . . .

XXII. A, White Bluff of the Columbia, 20 miles above Pasco, Wash.; $B$, Columnar lava at Cactus siding, 5 miles south of Connell, Wash...

XXIII. Mount Adams, as seen from the Northern Pacific trains near Toppen-



XXIV. A, Yakima Canyon, Wash.; $B$, Columnar andesite near Yakima

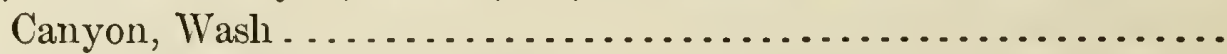

XXV. Beautiful Lake Keechelus, Wash.........................

XXVI. The almost impassable tangle of a Washington forest.............. XXVII. Mount Rainier, "monarch of the Cascades," as seen from the boulevard on the shore of Lake Washington, Seattle, Wash..........

Page. 


\section{FIGURES.}

FIgure 1. Section across Mississippi Valley between St. Paul and Fort Snell- Page. ing, Minn................................... 11

2. Diagram showing northward rise of the rocks in the vicinity of

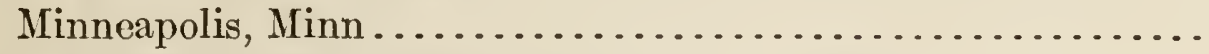

3. Diagram showing probable origin of many kettle holes..........

4. Section of Buffalo River delta, Minn .....................

5. Section of Herman beach ridge west of Magnolia, N. Dak ........

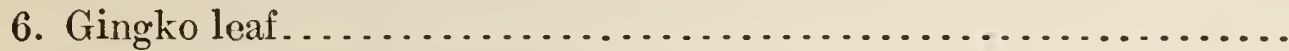

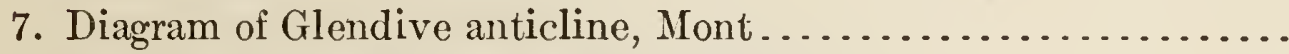

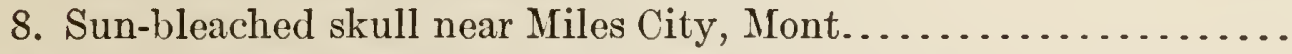

9. Diagram showing the thinning out and coming in of formations from Black Hills, S. Dak., to Billings, Mont................

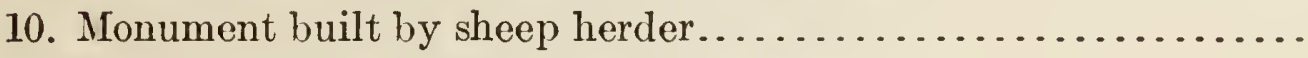

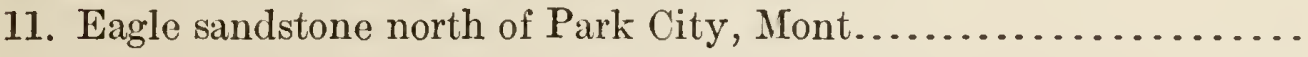

12. Cross section to illustrate the change in the formations between

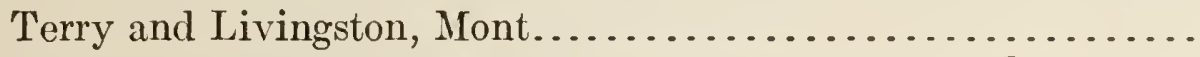

13. Cross section showing the rim of the mountains south of Livingston,

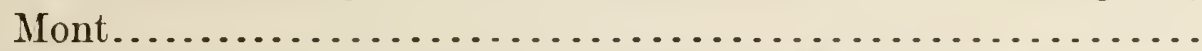

14. Diagram showing the structure of Cinnabar Mountain, Mont.....

15. Dike cutting coal bed and sill intruded in a position to affect the



16. Vertical fold in Madison limestone west of Chestnut, Mont.......

17. Upturned Madison limestone and associated rocks, forming the Bridger Range, Mont..............................

18. Southeast side of the great synclinal basin north of Logan, Mont..

19. Diagram to explain the course of Jefferson River west of Willow

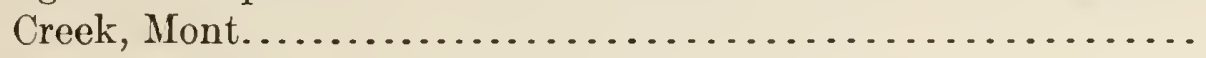

20. Section of great anticlinal fold near Lime Spur, Mont ..........

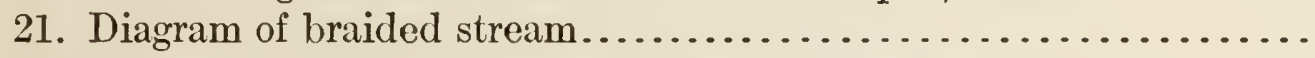

22. Diagram of Continental Divide east of Butte, Mont...........

23. Diagrams illustrating the ways in which the broad valleys of the Rocky Mountain region were formed....................

24. Sections along Northern Pacific Railway between Durant and Drummond, Mont., showing probable mode of formation of Deer

(2)

.

.

.

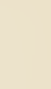

3

4

9

5

8

9

1

07

12





\section{INDEX OF RAILROAD STATIONS.}

$\Lambda$.

Akron, Wash.....................

Aldrich, Minn..................... 26

Alfalfa, Wash................... 172

Algoma, Idaho...................

Allard, Mont.................... 65

Allen, Mont.

Almont, N. Dak.

55

Alta, N. Dak.....................

Angora, N. Dak...................

Anoka, Minn.................... 17

Antelope, N. Dak................. 58

$\Lambda$ pple Creek, N. Dak.................

Argo, Wash.

Arlee, Mont......................... 138

$\Lambda$ thol, Idaho..................... 155

Auburn, Waish.................... 191

Audubon, Minn.................. 31

Austin, Mont....................... 124

$\Lambda$ von, Mont.................... 126

B.

Babb, Wash..

Badger, Wash

Baileys, Minn

Beach, N. Dak................... 63

Bearmouth, Mont................ 130

Beatrice, Wash.....................

Beaver Hill, Mont.

Becker, Minn..................... 18

Bedford, Mont..................... 120

Belfield, N. Dak. sheet.

23

2

Carney, Mont......................

Casselton, N. Dak................. 38

Cato, Mont.........................

Central Park, Mont.................. 98

Chama, N. Dak.................... 10

Chandler, Wash.....................

Cheney, Wash..................... $162 \quad 22$

Chestnut, Mont.................. $96 \quad 15$

Chicory, Mont..................... $90 \quad 15$

Clark Fork, Idaho................. $151 \quad 20$

Clarkston, Mont................... $117 \quad 16$

Clealum, Wash..................... $180 \quad 26$

Clear Lake, Minn..................... 19 
D

Page. Sheet.

Daileys, Mont.

91

Dale, Minn.

15

Darling, Minn.

Dawson, N. Dak.................. 46

Dayton, Minn.................. 18

De Smet, Mont................... 137

Deer Lodge, Mont.................. 114

Dehart, Mont.

Demores, N. Dak................. 63

Dempsey, Mont..................

Denton, Idaho.

Detroit, Minn.................... 30

Dewey, Mont.....................

Dickinson, N. Dak............... 60

Dilworth, Minn................. 35

Dixon, Mont................... 140

Don, N. Dak..

Dopelius, Minn.

Dower Lake, Minn.

Driscoll, N. Dak................. 46

Drummond, Mont............... 129

Dud̄ley, Wash.

Durant, Mont.

E.

Eagle Gorge, Wash............... 186

Eagles Nest, N. Dak.

East Helena, Mont................ 121

Easton, Wash.................. 182

Eckelson, N. Dak................. 43

Eddy, Mont.................... 144

Eland, N. Dak....................

Eldridge, N. Dak.................. 45

Electric, Mont................... 93

Elk River, Minn................. 18

Ellensburg, Wash.................. 177

Elliston, Mont................... 126

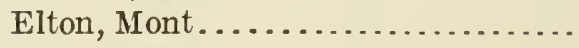

Eltopia, Wash ................... 168

Emery, Wash ....................

Emigrant, Mont................ 91

Empire, Wash.................... 172

Erie, Wash.....................

Essig, Wash..................... 165

Eustis, Mont.

Evaro, Mont. 137

F.

Fallon, Mont. 68

Fargo, N. Dak.................... 36

Fife, N. Dak.....................

Finch, Mont.................... 76

Fishtrap, Wash . . ................ 163

Flathead, Mont

Forsyth, Mont................... 75

Fort Keogh, Mont................ 70

Fort Snelling, Minn. .............. 10

Foster, Mont..

Frazee, Minn. .................... 30

Frost, Mont.................... 144

Fryburg, N. Dak................ 61

Furlong, Mont.....................

G.

Gardiner, Mont 91

Garrison, Mont. 115

Geneva, N. Dak
Page. Sheet.

Gibbon, Wash................... 24

Glade, Wash.....................

Gladstone, N. Dak................ 59

Glendive, Mont.................. 65

Glenullen, N. Dak................. . 56

Glyndon, Minn................. 35

Gold Creek, Mont................. 128

Gordon, Mont...................

Granite, Idaho.................. 154

Gregory, Minn.................... 21

Gregson, Mont...................

Greycliff, Mont................. 86

H.

Hackney, Mont................... 16

Haggart, N. Dak.................. 4

Haskell, Mont..................... 18

Hathaway, Mont................. $72 \quad 11$

Hatton, Wash................... 23

Hauser, Idaho................... $155 \quad 21$

Hawley, Minn..................... $31 \quad 3$

Hebron, N. Dak................... $58 \quad 8$

Heckman, Mont.................. 10

Helena, Mont..................... $121^{\circ} 17$

Hell Gate, Mont.................. 18

Henry, Wash................... 27

Heron, Mont...................... $149 \quad 20$

Hillside, Wash................... : $\quad 25$

Hobart, N. Dak................... 5

Hodges, Mont..................... $65 \quad 10$

Homestake, Mont.................. $106 \quad 16$

Hope, Idaho.................... $151 \quad 20$

Hoppers, Mont.................... 15

Horton, Mont..................... 11

Hot Springs, Wash............... $186 \quad 27$

Howard, Mont................... $76 \quad 12$

Hoyt, Mont..................... $68 \quad 10$

Humphrey, Wash............... $186 \quad 27$

Huntley, Mont................... $80 \quad 13$

Hysham, Mont.................... $77 \quad 12$

I.

Indio, Wash

26

Iona, Mont...................... 10

Irvin, Wash. .................... $159 \quad 21$

Jamestown, N. Dak............... 44

Joppa, Mont.................... 72

K.

Kanaskat, Wash.................. $189 \quad 27$

Kamm, Mont................... 11

Kennedy, Wash...................

Kennewick, Wash . . . . . . . . . . . . . . . 169

Kent, Wash...................... $193 \quad 27$

Keystone, Wash................... 22

Kildee, Mont..................... $146 \quad 20$

Kiona, Wash.................... 170

Kline, Wash...................... 22

Knife River, N. Dak................ 8

Knowles, Mont................... 19

Kohrs, Mont..................... 18

Kootenai, Idaho....................

Kountze, Wash.................. $\quad 26$

Kurtz, N. Dak................. 8 
Page. Sheet.

Ladoga, N. Dak...................

Lake Park, Minn................... 31

Laurel, Mont..................... 82

Lehigh, N. Dak................. 59

Lemolo, Wash...................

Lester, Wash..................... 186

Lignite, Idaho......................

Lime Spur, Mont................... 103

Limekiln Spur, Mont...............

Lincoln, Minn.................... 24

Lind, Wash....................... 165

Little Falls, Minn................. . 22

Livingston, Mont.................. 88

Lockwood, Mont.....................

Logan, Mont.................... 99

Lombard, Mont.................... 118

Louisville, Mont....................

Luce, Minn........................ 28

Lyons, N. Dak.

M.

Mabton, Wash.................... 171

McDonald, Mont.................... 140

McHugh, Minn.

McKenzie, N. Dak................ 49

Magnolia, N. Dak.................... 39

Mandan, N. Dak.................. 52

Manhattan, Mont

Manitoba Junction, Minn............. 31

Mapleton, N. Dak................. 38

Marsh, Mont..................... 68

Marshall, Wash.................... 161

Martin, Wash...................... 184

Maywood, Wash.................. 186

Medina, N. Dak................... 45

Medora, N. Dak................... 62

Merrill, Mont...................... 85

Mesa, Wash...................... 167

Miles City, Mont.................. 70

Miner, Mont........................ 92

Minneapolis, Minn................. 16

Minnehaha Falls, Minn.............. 10

Misko, Mont..

Mission, Mont..................... 88
Page. Sheet.

Oneida, Mont.................... 14

Oriska, N. Dak.................. $41 \quad 5$

Orwell, Mont..................... 18

Osborn, Mont.................... 13

Oswego, N. Dak.....................

Otis, Wash....................... 21

Ozoma, Idaho.................... 20

P.

Paha, Wash....................... $165 \quad 23$

Palmer Junction, Wash.............. $189 \quad 27$

Paradise, Mont..................... $142 \quad 19$

Park City, Mont.................... $83 \quad 14$

Parker, Wash....................... $173 \quad 25$

Parkwater, Wash................... 21

Pasco, Wash...................... $168 \quad 24$

Patcum, Mont...................... 14

Perham, Minn..................... $27 \quad 3$

Perma, Mont..................... 141

Philbrook, Minn................... $25 \quad 2$

Pipestone, Mont...................... $105 \quad 16$

Placer, Mont........................ 17

Plains, Mont....................... $143 \quad 19$

Pomona, Wash..................... 25

Pompeys Pillar, Mont................ $79 \quad 13$

Prosser, Wash...................... $171 \quad 24$

Providence, Wash................. $165 \quad 23$

Q.

Quebec, Mont....................

R.

Race Track, Mont.................. 114

Ramsey, Idaho...................... 155

Rancher, Mont.................. 76

Randall, Minn...................... 23

Rankin, N. Dak...................

Rapids, Mont.................... 14

Rathdrum, Idaho................. $155 \quad 21$

Ravalli, Mont....................... $138 \quad 19$

Ravensdale, Wash.................. $189 \quad 27$

Rea, Mont........................ 12

Reed Point, Mont................... $85 \quad 14$

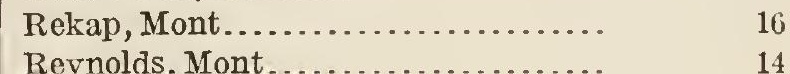


Page. Sheet.

Schley, Mont........................

Scoria, N. Dak.................... 61

Seattle, Wash.................... 194

Sedalia, N. Dak....................

Selah, Wash....................... 176

Sentinel Butte, N. Dak............ 63

Shirley, Mont.....................

Shoshkin, Wash....................

Sifton, N. Dak....................

Silver Bow, Mont................ 111

Sims, N. Dak...................... 55

Skones, Mont.....................

Skyline, Mont.....................

Smeads, Mont......................

South Heart, N. Dak................. 60

Southdown, N. Dak................

Sphinx, Mont.....................

Spire Rock, Mont................... 105

Spiritwood, N. Dak............... 44

Spokane, Wash.................... 160

Sprague, Wash.................... 164

Springdale, Mont................ 86

Stampede, Wash................... 184

Staples, Minn...................... 25

Steele, N. Dak.................... 46

Sterling, N. Dak.................... 48

Stockwood, Minn.................. 35

Storey, Mont.......................

Stuart, Mont.................... 111

Sully Springs, N. Dak.............. 61

Sunnyside Junction, Wash...........

Sweetbrier, N. Dak...

T.

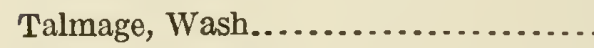

Tappen, $\mathbf{N}$, Dak................... 46
Taylor, N. Dak..................

Teanaway, Wash.................. 179

Terry, Mont...................... 69

Thorp, Wash..................... 178

Thompson Falls, Mont............. 145

Thrall, Wash.................... 177

Threeforks, Mont................. 100

Tokio, Wash......................

Toppenish, Wash.................. 172

Toston, Mont...................... 119

Tower City, N. Dak............... 41

Townsend, Mont................. 119

Trail Creek, Mont..................

Trident, Mont................... 117
Page. Sheet.

Trout Creek, Mont............... $148 \quad 20$

Turah, Mont.................... 19

Tuscor, Mont...................... 20

Tusler, Mont...................... 11

Tyler, Wash...................... $162 \quad 22$

$\mathrm{U}$.

Ulmer, Mont................... 11

Urbana, N. Dak................... 5

V.

Vale, Wash....................... 23

Valley City, N. Dak............... $42 \quad 5$

Velox, Wash...................... 21

Vermilion, Mont................... 20

Verndale, Minn.................... $26 \quad 2$

Vista, Wash....................... $169 \quad 24$

Waco, Mont..................... $78 \quad 13$

Wadena, Minn..................... $26 \quad 3$

Waldon, N. Dak................. 9

Wapato, Wash.................... $173 \quad 25$

Warm Springs, Mont.............. $113 \quad 18$

Watab, Minn.................... 2

Watago, Mont.................... 14

Weeksville, Mont.................. $144 \quad 19$

Welch, Mont..................... 16

West End, Mont.................. 15

Westmond, Idaho................. 21

Weston, Wash..................... 26

Wheatland, N. Dak............... $39 \quad 4$

White Pine, Mont................ . 20

Whitehall, Mont................... $105 \quad 16$

Wibaux, Mont.................. $64 \quad 10$

Willis, Mont...................... 18

Willow Creek, Mont................ $101 \quad 16$

Windsor, N. Dak.................. $45 \quad 6$

Winston, Mont................... $120 \quad 17$

Woodlin, Mont..................... 20

Worden, Mont..................... 13

Wymer, Wash.................... $176 \quad 25$

Yakima, Wash................... $174 \quad 25$

Yates, Mont...................... 10

Yegen, Mont.................... 13

Youngs Point, Mont............... $83 \quad 14$

Z.

Zenith, N. Dak................... 9

Zero, Mont...................... 11 


\section{GENERAL INDEX.}

A.

Absaroka Range, Mont., formation of....... 87 Alden, W. C., on glacial deposits in Washington.................... 191-192

Alder, Mont., railroad to................. 105 Alder Gulch, Mont., metal production of .... 105 Alexandria, Minn., railroad to. Altamont moraine, N. Dak.-S. Dak., position of ........................ 40,46

Anaconda, Mont., railroad to............ 112 Anceney, Mont., railroad to ............... 98-99

Ankylosaurus, description of.............. 74 Antelope moraine, N. Dak.-S. Dak., nature and position of .............. 41,44 Anticline, examples of............... 102-103, 116 Glendive, Mont.-S. Dak., description of. . 68 Pryor Mountain, Mont., description of... 79 Ashley, Col. William H., trading post established by...

A tanum Ridge, Wash situation of .

\section{B.}

Badlands, nature of .................... 61-62 of North Dakota, plates showing..... 52, 62,63 origin of name of ................... 61 Ballmer, N. E., work of.................. 4 Basins, methods of forming.............. 138 Bear Gulch, Mont., discovery of gold on..... 130 Bearpaw shale, description of............. 74-75 Bedding of flood deposits, explanation of.... 160 Beets, sugar, growing of, in Montana....... 81 Belt series, nature and members of........ 145-146 Benetsee, François, discovery of gold in Montana by................. 128 Rig Relt Mollntains Mont view of
Page.

Buffalo River, Minn., delta of, extent of . .... 33, 34 Bull Mountain, Mont., view of ........... 104 Burns, Mont., situation of .................. $\quad 66$ Butler, B. S., on mining at Butte, Mont.... 108-110

Butte, Mont., ore deposits at............. 109-110 railroad facilities of ................... 110

Buttes, plates showing................ 62,63

C.

Cabinet Gorge, Idaho, description of........ 150 plate showing....................... 143

Camas Hot Springs, Mont., situation of...... 141

Camels Hump, N. Dak., situation of......... 63

Campbell beach, portion of, at Wheatland, N. Dak...................... 39

Canfield, T. H., wheat growing by.......... 38

Canyon, box, definition of ............... 118

Canyon Ferry, Mont., power plant at........ 121

Carver, Jonathan, exploration by.......... 18

Cascade Range, Oreg.-Wash., forming of... 172-173 uniform elevation of................ 184 uplift of............................ 167 views of .......................... 171

Cass, George W., town named for........... 38 wheat growing by.................... 38

Cass Lake, Minn., railroad to ............. $\quad 26$

Catholic missions, establishment of......... 139

Cement, making of, at Trident, Mont....... 117

Channel, cutting of, in hard rock.......... 101-102

Charboneau, Toussaint, service of, as interpreter..................... 49

Cheney, Benjamin P., wheat growing by .... $\quad 38$

Chilton Lake, Minn., situation of ........... 30

Cinnabar Mountain, Mont., structure of..... 93 view of.$\ldots \ldots \ldots \ldots \ldots \ldots \ldots \ldots \ldots \ldots$ 
Colville Lake, Wash., situation of........... 164

Concretion, definition of ................. 67

Confederate Gulch, Mont., gold production of. 120

Continental Divide, approach to......... 105-106 crossing of, at Mullan Pass, Mont........ 124 origin of ......................... 106-107 Cooperstown, N. Dak., railroad to.......... 43 Copper, output of, at Butte, Mont........ 108-109 Coriacan Defile, Mont., situation of......... 137 Coteau, meaning of ..................... $\quad 45$ Coteau du Missouri, N. Dak., situation of.... 45 Cottonwood, prevalence of................ 68-69 Coulee, meanings of.................... 42 Coulee City, Wash., railroad to.......... 162, 166 Coulson, Mont., early settlement at......... 81

Cowan, John, discovery of gold at Helena, Mont., by....................

"Cow puncher," disappearance of .......... Crane, Mont., situation of . .................

Crazy Mountains, Mont., description of . .... 86-87 views of ....................... 85, 86

Crook, Gen., part of, in Little Bighorn expedition.......................

Crookston, Minn., railroad to.............. Crosby, Minn., iron mining at............. Cruse, Thomas, Drumlummon lode discovered by ...................

Custer, Gen., last battle of.

Cuyuna iron range, Minn., discovery and opening of................ 15, 22-23

map showing. 26

D.

Dakota Products Co., lignite mine of N. Dak. . Daly, Marcus, mining operations of......... Darby, Mont., railroad to . . . . . . . . . . . . . . Daughters of the American Revolution, tablet erected by ................. De Mores, Marquise Medora, town named for. De Smet, Father, Indian mission founderl by. Deer Lodge Valley, Mont., how formed ... 111-112,

Detroit Lake, Minn., situation of . . . . . . . . . . . Devils Lake, N. Dak., railroad to............ Dickinson, W. S., town named for........... Divide between Hudson Bay and Mississippi River drainage systems, Minn.N. Dak., situation of .......... 27, 43 Drift, thin, source of................... 54 Drumlummon mine, Mont, history of...... 123 Dry farming in North Dakota, rainfall adequate for................... 36, 60 Duluth, Minn., railroads to.......... 20, 21, 23,25 Duwamish Valley, Wash., situation of....... 193

\section{E.}

Eagle Butte, Mont., situation of ........... 66-67

Electric, Mont., coal field near. geologic section exposed at . lectric Peak, Mont., elevation of ............ Elliott Bay, Wash., map showing........... Emigrant Peak, Mont., plate showing.......

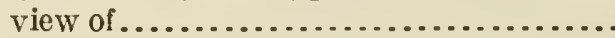

Enumclaw, Wash., railroad to............... Erosion, effects of........................ forms produced by ................... plate showing ...................

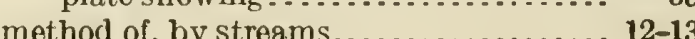

F. Page.

Falls of Minnehaha, Minn., origin of......... 13 plate showing...................... 10

Falls of St. Anthony, Minn., recession of.... 13 view of ............................. 16

Fargo, William G., town named for ........ 36 Faults, overthrust, examples of....... 102-103,116 production of....................... 143-144

Fergus Falls, Minn., railroad to ........... 26

Fergus Falls moraine, Minn., position of..... 41

Ferns, fossil forms of..................... 57 prevalence of, in Washington and Oregon....................... 186, 188

Fish Lake, Idaho, situation of ............. 154

Flathead Indian Reservation, Mont., description of ...

Flathead Indians, summer camp of, plate showing..................... 119

Flathead Lake, Mont., situation of......... 140

Flathead River, Mont., plate showing...... 142

Flax, growing of, in North Dakota.......... 37

Folds, production of.................... 143-144

vertical, example of.................. 96

Forest in Washington, plate showing....... 194

pine, extent of, in Washington.......... 179

second growth of, in Washington . . . ..... 186

Forest Service, U. S., fire station of......... 145

Formations exposed along Missouri River, sequence of................... 53

thinning out and coming in of, diagram showing..................... 75

Forsyth, Gen. J. W., town named for....... $\quad 75$

Fort Abraham Lincoln, N. Dak., situation of. $\quad 52$

Fort Harrison, Mont., situation of .......... 123

Fort Lincoln, N. Dak., situation of......... 51

Fort Missoula, Mont., situation of........ 134-135

Fort Sarpy, Mont., situation of ............ $\quad 77$

Fort Snelling, Minn., access to............. 11

building of ....................... 10,14

position of, on the Red River trail...... 18

Fort Union formation, outcrops of.......... $\quad 56$

plant fossils of..................... 57,59

Fort Wright, Wash., situation of .......... 160

Fox Hills sandstone, nature of............ 53

Fruit. See names of States.

Fur traders, explorations by............... 147

G.

Gaging stations, information obtained at.... 174

Gallatin, Albert, river named for.......... 100

Gallatin Range, Mont., rocks forming....... $\quad 90$ structure of........................ 90 view of ........................... 91

Gallatin Valley, Mont., fine farms in....... 96-97 origin of sediments in............... 98

Garnet Range, Mont., folds in............. 129

Garrison, William Lloyd, town named for... 115

Gary moraine, N. and S. Dak., position of. . 40-41, 46 Geologic time, chart showing divisions of.... 2 Gibbon, Gen., part of, in Little Bighorn expedition.................... 71-72

Gilmore, Charles W., on the animals of Lance time........................ 73-74

Ginkgo, history of ...................... $57-58$

Glaciation, deposits from, in Washington.. 191-192 evidences of, in Clark Fork valley, Mont. $\quad 149$

in Yakima Valley, Wash......... 181-182 


\section{GENERAL INDEX.}

Page.

Glaciation, history of, in Minnesota. ... 15-16, 26-29 in the Dakotas.................. 40-41

in Washington................ 185-186 smoothing effect of................. 152 Sce also Ice sheets.

Glacier on McDonald Peak, Mont., plate showing ......................

view of ..............................

Glacier Peak, Wash., altitude of.............

G lendive Creek, Mont., hunting on .......... fold, deposits of, in Washington............

Gold Creek, Mont., discovery of gold on..... Grand Forks, N. Dak., railroad to........... Granite, boundary of, in Minnesota.......... quarrying of, near St. Cloud, Minn...... 19-20 Gray, Capt. Robert, mouth of Columbia River discovered by .......... 168-169 Great Falls, Mont., railroad to............ 121 Great Spirit, Dwelling of, Minn.

Green River, Wash., diversion of, by an ice

sheet...................... 187

"Gumbo spots," nature of................. 38

\section{H.}

Haggin, James B., mountain named for...... 112

Hamilton, Mont., railroad to ............... 134

Harold Lake, Minn., situation of............ 30

Hauser Lake, Mont., power plant at........ 121

Havre, Mont., railroad to................. 123

Hayden Lake, Idaho, situation of........... 154

Hell Gate Canyon, Mont., description of... 129-130 origin of name of..................... 136 road through $. . . . \ldots \ldots \ldots \ldots \ldots \ldots \ldots . . .131-132$

Hennepin, Father Louis, explorations by.... 18

Henry, Alexander, explorations by ......... 37, 147

Herman beach, Minn.-N. and S. Dak.-Canada, formation of.............. 32-33 vierr of, near Magnolia, N. Dak......... 39 "High line" trestle over Sheyenne River, N. Dak., plate showing..........

view from........................... plate showing.................... Homestake Summit, Mont., view from, plate showing .....................
Jocko Valley, Mont., Indian camp in, plate showing..................... 119

situation of........................ 137 Johnson, Edwin F., town first named for .... 51 Judith River sandstone, nature of. ...... . 76,83-84 Jumbo Mountain, Mont, beach lines on..... 134

$$
\text { K. }
$$

Kachess Lake, Wash., description of......... 182 Kalispell, Mont., access to ................ 138 Kautz, Lieut. $\Lambda . T$., discorery of glaciers in the United States by........... 195

Keechelus Lake, Wash., origin of......... 182, 183 plate showing...................... 175

Keogh, Capt. Myles W., fort named for..... 70 Kettles, formation of .................... 29-30 Knife River and Muddy Creek, N. Dak., divide separating valleys of...... 57

Knopf, Adolph, on the history of Helena, Mont.................... 121-122

Knowlton, F. H., on the plants of the Fort Union formation.............. 5 57-59 on present and fossil plants of Washington...................... 189-191

\section{L.}

La Moure, N. Dak., railroad to.............. Lake Agassiz, glacial, Minn.-N. and S. Dak.Canada, description of.......... 31-34 map showing...................... 40


silt of, fineness of .................... 35 Lake Alexander, Minn., situation of........ 24 Lake Como, Minn., origin of.............. $\quad 16$ Lake Creek, Wash., terraces on............ 160 Lake Minnetonka, Minn., access to......... 13 Lake Missoula, glacial, Mont.-IVyo., beach lines of .................... 134, 137 map showing ....................... 144 probable history of . . . . . . . . . . . . . . . 134-136 Lake Washington, Wash., ship canal to...... 194 Lakes, alkaline, near Sanborn, N. Dak..... 43 formation of, in Montana ............. 113-114 Tertiary, map of western Montana show- 
Lewis and Clark Cavern National Monument, Mont., situation of. .

Lignite, beds of, at Hodges, Mont........... beds of, at Medora, N. Dak.............

Lignite, beds of, burning of............... 56,6 beds of, cracks produced by burning of, plate showing ................. mining of, at Lehigh, N. Dak.......... 59-60

at New Salem, N. Dak............ 54

at Sims, N. Dak.................. 55

nature and value of.............. 54-55, 60 outcrop of, in the canyon of Little Missouri River, plate showing..

Lisa, Manuel, trading post established by.... Iittle Missouri River, N. Dak.-S. Dak., badlands on.................... 61-62

lignite on............................

plate showing...................

Livingston, Charles, town named for.......

Livingston, Mont., coal beds near...........

Livingston formation, nature of............

Loess, origin of, in Washington............

Lolo Peak, Mont., view of.................

Lombard, Mont., cliffs at, plate showing.....

Lonc Mountain, Idaho, view of............

Louisiana Territory, acquisition of..........

exploration of...................... 20-21

Lower Yellowstone reclamation project, Mont.-N. Dak., description of...

\section{M.}

McAdows Canyon, Mont., situation of....... McClellan, Capt. Gcorge B., exploration by . 124, 125 McDonald Peak, Mont., glacier on, plate showing......................

McHenry, N. Dak., railroad to............. McKay coal bed, Wash, , character of........ Madison, James, river named for.

Madison limestonc, cliffs of, at Lombard, Mont., plate showing............

Madison River, Mont., power development on..........................

Manastash Ridge, Wash., situation of....... Mandan Indians, reservation of N. Dak...... Maple River, N. Dak., drainage system of... Marent viaduct, Mont., situation of.......... Marysville, Mont., mining at............. Medical Lake, Wash., railroad to........... Mendota, Minn., settlement of..............

Mesabi iron range, Minn., geology of........ 23-24 map showing........................

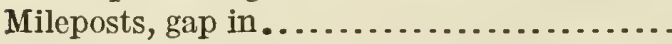

Miles, Gen. Nelson $\Lambda$. , town named for ......

Minnesota, geography and products of...... 14-15 origin of name......................

Minnesota River, changes in course of, near St. Paul, Minn............... 11-12

Minnesota State rcformatory, situation of.... 19

Miragc, description of.................. $\quad 35$

Mission Range, Mont., structure of.......... 141

views of . ...................... 139, 140

Mississippi River, changes in course of, near St. Paul, Minn ............... 11-13 cutting of channel by, at St. Paul, Minn.................... 8, 11-13

Missoula, Mont., early isolation of........... 136

Missoula County, Mont., included successively in four Territorics.

\section{8}

Palme route of..... 18-19

Palm leaf, fossil, plate showing ............ 75

end Oreille Lake, Idaho, description of..... 151 steamboats on.................... 151, 154

viaduct over. . . . . . . . . . . . . . . . . . 152

view of ......................... 152

Pencplains, formation of .............. 153

Pennington iron mine, Minn., description of. $\quad 23$

Petrified wood, formation of.............. 62

plate showing...................... 62

specimen of....................... 128

Philipsburg, Mont., railroad to............ 129

Phosphate rock, deposit of, near Elliston,

Mont...................... 125

Pierre shalc, nature of................... 53,67 
Page.

Pike, Lieut. Zebulon M., explorations by . 18, 20-21 Pingree, N. Dak., railroad to............... 44 Pioneer, Mont., gold placers at............ 128 Plummer, Minn., situation of. ............ 31 Pokegama Spring, Minn., situation of...... 30 Polson, Mont., access to.................. 138 Pompeys Pillar, Mont., description of...... $\quad 79$ inscription by Capt. Clark on, plate showing.......................... plate showing . ......................... Pony, Mont., railroad to.................... Population, authority for................. Power from rivers of Minnesota, utilization of $. \ldots \ldots \ldots \ldots \ldots \ldots \ldots \ldots .14,16,20,22$ Prickly Pcar Crcck, Mont., farms on.... "Prow of the Battleship," Pyramid Park, N. Dak., plate showing..........

Puget, Peter, sound named for . ............. Puget Sound, Wash., exploration of ......... origin of .............................

Pyramid Park, N. Dak., erosion in .......... natural monuments in, plate showing...

R.

Racetrack Peak, Mont., situation of ......... Rainier, Rear Admiral, mountain named for. Range, use of term, for iron deposits. ......... Ransome, F. L., on the Cour d'Alene mining district................. 156-157

Rattlesnake Ridge, Wash., situation of...... 173

Ravalli, Father Anthony, missionary work of, among the Indians.............

Red Lodge, Mont., railroad to................

Red Lodge coal field, Mont., description of.. 82-83

Red River, Minn.-S. and N. Dak.-Canada, character of....................

Red River trail, part of....................

Red River valley, fertility of, first demonstration of........................

history and character of $\ldots \ldots \ldots \ldots \ldots . . .36-38$

mirage in.......................... 35

origin and nature of .................. 33-34

Reno, Maj., share of, in Little Bighorn expedition.................... $71-72$
Sarpy, Col. Peter, creek and trading post named for.....................

Sauk Center, Minn., railroad to.............

Savage, Mont., situation of ................ 66

Saxton, Lieut. R., explorations by ......... 147

Schist, production of .................... $\quad 155$

Seattle, Wash., grading in ................ 193

Seattle, Wash., water supply of............ 188

Sedimentary rocks, deposition of .......... 19,42

Selkirk, Earl of, settlement ncar Winnipeg, Manitoba, made by............ 37

Sequoia, fossil forms of ................... $\quad 57$

Sheep Cliffs, Mont., structure of ............ 87-88

Sheep herding in Montana, plates showing... $\quad 76$

Sheep range of Montana, description of..... $77-78$

Sheyenne River, N. Dak., discharge of...... 43

"high line" bridge across, plate showing......................... 11

"Shining Mountains," origin of name....... 81-82

Sidney, Mont., situation of ............... 66

Signal Butte, Mont., situation of ............ 69-70

Silver Bow Creek, Mont., cutting of canyon by $\ldots . . . \ldots \ldots \ldots \ldots \ldots \ldots . .111$

Silver Bow Canyon, Mont., plate showing... 107 Sitting Bull, leader of Sioux insurrection..... 71

Smith, George Otis, preface by............ 3-4

Snipes Mountain, Wash., situation of....... 173

Soil, absorption of rainfall by............. 162

Sprague, Gen. J. W., town named for...... 164

Spike, last, on the Northern Pacific Railway, celebration of driving.......... 127

Spire Rock, Mont., view of............... 105

Spirit Lake, Idaho, situation of............ 154

Spokane River, Idaho-Wash., history of..... 159

Staack, J. G., work of ................... 4

Stampede tunnel, Wash., ventilation of ...... 184

Stevens, Gov. Isaac I., first Pacific railroad survey led by................ 18, 124

Stevensville, Mont., railroad to............ 134

Stone, R. W., on phosphate deposits in the Rocky Mountains. ........... 125-126

Stream, braided, how formed.............. 104

Striæ, glacial, examples of ............... 153

Synclinal trough, example of.......... 99, 117, 129






\section{GENERAL INDEX.}

Page.

Tuff, volcanic, nature of.

Tufts, W. O., work of....................

Twin Bridges, Mont., railroad to ............

Tyrannosaurus, description of .

$$
\text { U. }
$$

Union Gap, Wash., gaging station at.

United States, western, relief map of........

University Mountain, Mont., beach lines on..

University of Minnesota, view of .

University of Montana, situation of...........

University of Washington, situation of......

Upham, Warren, on the mirage in Red River valley

\section{V.}

Valley City, N. Dak., plate showing.........

Valleys, chance formation of, in Minnesota...

Rocky Mountain, how formed ........ . 111-112

Verandrye, exploration by............ 37,51, 67

Virginia City, Mont., situation of.......... 105

Vermilion Creek, Mont, , early history of..... 148

Volcanic agglomerate, nature of.......... $\quad 85$

Volcanic breccia, exposure of . ............ 91-92

W.

Waconia moraine, N. Dak.-S. Dak., position of ...................... 41, 43

Wallace, Idaho, situation of.
Warren River, Minn., relation of, to Lake

Agassiz.................... 32

Washington, exploration of, by Capt. Wilkes.. 195

Washington, fish hatchery of............. 190

geologic history of . . . . . . . . . . . . . . . 165-167

history and products of. ............ . 156-158

plants of, present and fossil.......... 189-191

rainfall in ......................... 196

Wells near Casselton, N. Dak., sources of water in ................... 38-39

White Bear Lake, Minn., situation of....... 13

Wickes, Mont., railroad built to ............ 122

Wilkes, Capt., exploration of Washington

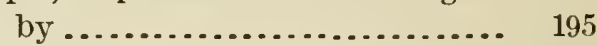

Willis, Bailey, on glaciation in Washington. 185-186

Winnipeg, Canada, railroad to............. $\quad 31$

\section{Y.}

Yakima Canyon, Wash., plate showing...... 174

Yakima River, gaps cut by................ 175

Yakima River valley, compound shape of.. 170-171 farms in .......................... 171 rainfall in.......................... 174

Yellowstone River, Mont., irrigation project on.......................... 66 origin of name of ..................... $66-67$ scenery along........................ $\quad 72$ 












$$
\text { 定6 }
$$





$$
\text { 定 } 6
$$

613 


$$
\text { - (i) }
$$



H.

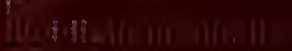

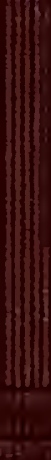

